\begin{tabular}{|c|c|c|c|}
\hline $\begin{array}{c}\text { FEB } 28 \underset{5}{2000} \\
\text { STA } 4\end{array}$ & ENGINEERING DATA TRANSMITTAL & 0 & 1. EDT 618010 \\
\hline
\end{tabular}

\begin{tabular}{|l|l|}
\hline $\begin{array}{l}\text { 2. To: (Recolving Organization) } \\
\text { DISTRIBUTION }\end{array}$ & $\begin{array}{l}\text { 3. From: (Originating Organtzation) } \\
\text { F. M. Maiden }\end{array}$ \\
\hline $\begin{array}{l}\text { 5. Pro/Prog/Dept/DW.: } \\
\text { Interim Stabilization }\end{array}$ & $\begin{array}{l}\text { 8. Deaign Authority/Dedign AgentCog. Engr: } \\
\text { W. F. Zuroff/J. Lamphere }\end{array}$ \\
\hline $\begin{array}{l}\text { 8. Orginator Romark: } \\
\text { Transmitted for release of the Operational Test Report (OTR) for } \\
\text { U-103 with attached Operational Test Procedure (OTP), (Ladder } \\
\text { Diagram printout for U-103 attached to OTP). }\end{array}$
\end{tabular}

11. Recolver Remarks: 11A. Decion Baselline Document? O Yos O No

4. Rolated EDT No.:

N/A

7. Purchase Ordor No.:

$$
\mathrm{N} / \mathrm{A}
$$

9. Equip./Componont No.:

N/A

10. Syatom/aldofradily:

single Shell Tank Farm 12. Meipor Acom. Dwg. No.:

$$
N / A
$$

13. PermilPermil Application No.:

$N / A$

14. Required Recpones Dats:

\begin{tabular}{|c|c|c|c|c|}
\hline \multirow{2}{*}{\begin{tabular}{|l}
15. \\
$\begin{array}{c}\text { (A) } \\
\text { lifm } \\
\text { No. }\end{array}$ \\
\end{tabular}} & \multicolumn{4}{|c|}{ DATA TRANSMITTED } \\
\hline & (B) Document/Drawing No. & $\begin{array}{l}\text { (C) Sheot } \\
\text { No. }\end{array}$ & $\begin{array}{l}\text { (D) Rov. } \\
\text { No. }\end{array}$ & (E) TWe or Description of Data Tranemittiod \\
\hline \multirow[t]{4}{*}{1} & HNF -5820 & ALL & 0 & Tank Farm U-103 \\
\hline & & & & Operational Test Report \\
\hline & & & & (OTR) with Attached \\
\hline & & & & OTP \& Ladder Diagram \\
\hline & & & & \\
\hline & & & & \\
\hline & & & & \\
\hline
\end{tabular}

$$
\text { N/A }
$$

\begin{tabular}{|c|c|c|c|}
\hline (F) & (C) & (H) & (I) \\
\hline $\begin{array}{l}\text { Approvel } \\
\text { Dopto } \\
\text { notor }\end{array}$ & $\begin{array}{l}\text { Regeon } \\
\text { ortinn } \\
\text { mital }\end{array}$ & $\begin{array}{l}\text { Orlot } \\
\text { netor } \\
\text { oteo- } \\
\text { tion }\end{array}$ & $\begin{array}{l}\text { Recolv- } \\
\text { of poro- } \\
\text { dition }\end{array}$ \\
\hline N/A & 1 & 1 & 1 \\
\hline & & & \\
\hline & & & \\
\hline & & & \\
\hline & & & \\
\hline & & & \\
\hline & & & \\
\hline
\end{tabular}

\begin{tabular}{|c|c|}
\hline Approval Designator (F) & \\
\hline $\begin{array}{l}\text { E, S, Q D OR N/A } \\
\text { (See WHC.CM-3- } \\
\text { Sec. 12.7) }\end{array}$ & $\begin{array}{l}\text { 1. Approval } \\
\text { 2. Rploase } \\
\text { 3. information }\end{array}$ \\
\hline
\end{tabular}

(F)
17.

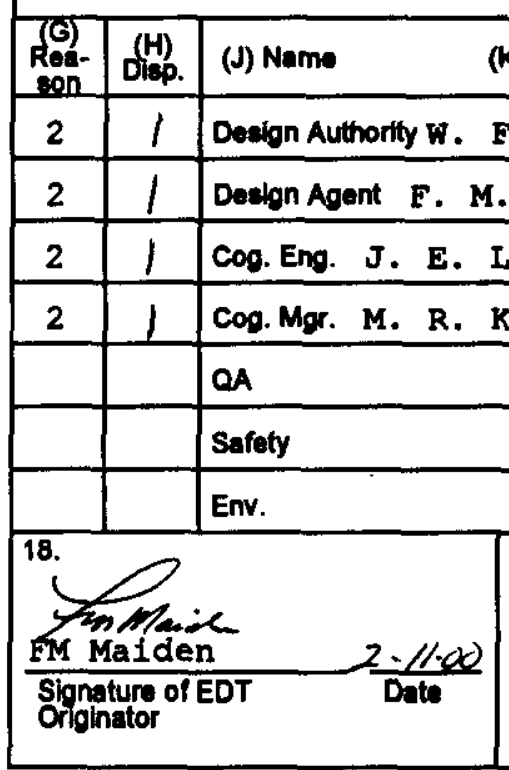

BD-7400-172-2 (10/97)

KEY

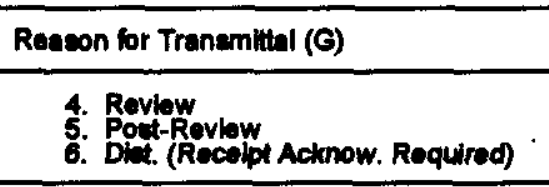

\begin{tabular}{|c|c|}
\hline \multicolumn{2}{|c|}{ Dlapodition (H) \& (I) } \\
\hline $\begin{array}{l}\text { roved } \\
\text { roved }\end{array}$ & $\begin{array}{l}\text { VWwed no/comment } \\
\text { vilwed w/comment }\end{array}$ \\
\hline
\end{tabular}

SIGNATUREIDISTRIBUTION
(Ses Approval Dedignator for required signatures)

\section{Diepockition $(H) \&(1)$}

dignaturea) 


\section{DISTRIBUTION SHEET}

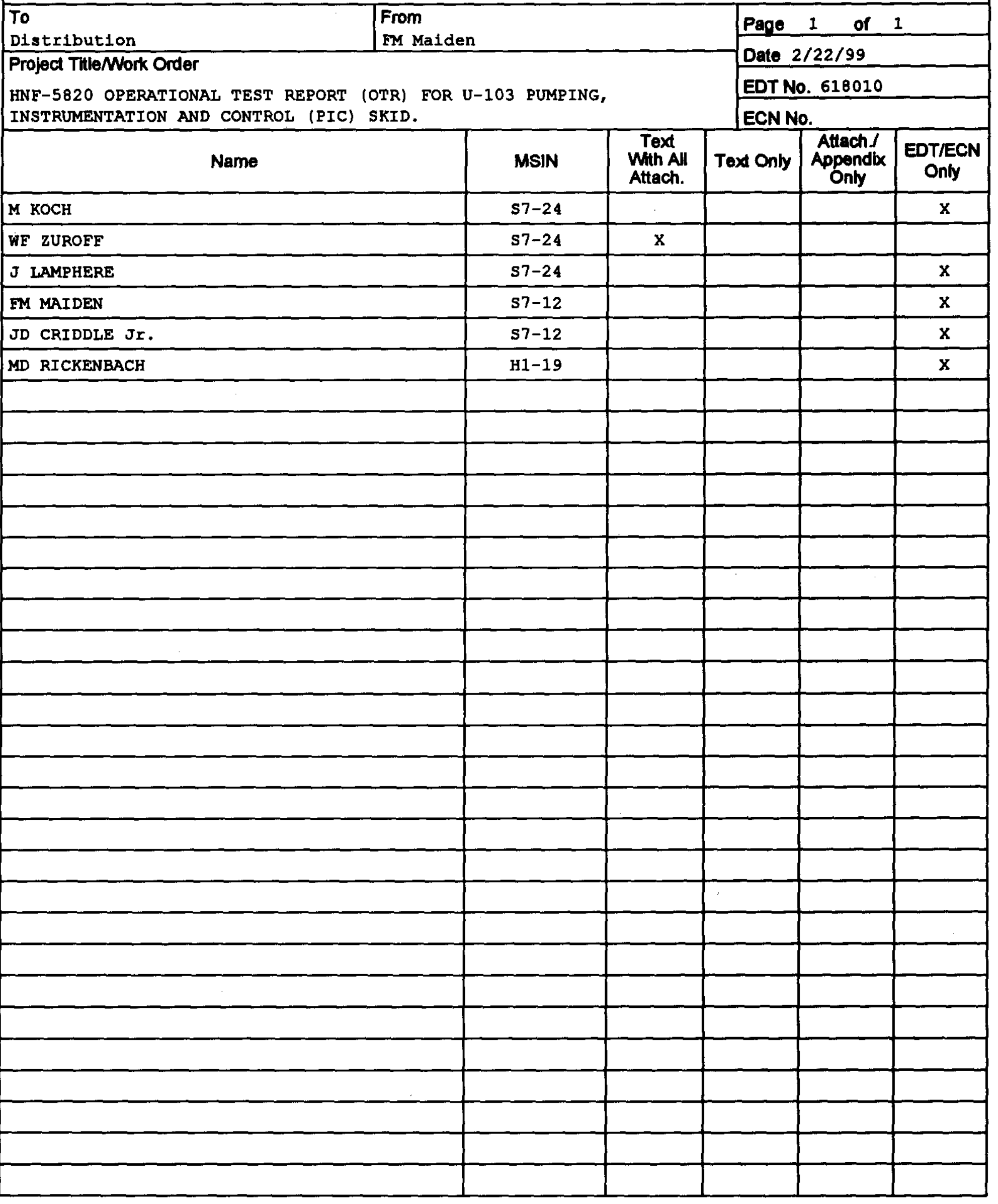




\title{
OPERATIONAL TEST REPORT (OTR) FOR U-103 PUMPING, INSTRUMENTATION AND CONTROL (PIC) SKID
}

\author{
Mike roch \\ Prepared by CH2MHILL Hanford Group, Inc. \\ Richland, WA 99352 \\ U.S. Department of Energy Contract DE-AC06-99RL14047

$\begin{array}{lll}\text { EDT/ECN: } 618010 & \text { UC: } 500 \\ \text { Cost Center: } 47000 & \text { Chamge Code: } 100850 \\ \text { B\&R Code: } & \text { EW3120071 } & \text { Total Pages: } 187\end{array}$

Key Words: U-103, OTR, OTP, LADDER DIAGRAM

Abstract: Attached is the completed Operation Test Procedure 10TP-200-004, Rev. $A-16)$. OTP includes a print out of the Programmable Logic Controller (PLC) Ladder Diagram. Ladder Diagram was designed for installation in the PLC used to monitor and control pumping activity for Tank Farm 241-U-103. The completed OTP and OTR are referenced in the Is PIC skid Configuration Drawing ( $\mathrm{H}-2-829998)$.

TRADEMARK DISCLAIMER. Robrence horein to any apecilic commercial product, procene, or eorvice by thade neme, trademark, manufacturer, or othenwies, does not necesvarlly conethute or imply lis endoreement, recommendation, or fevoring by the United States Government or any agenoy thereof or tis contractore or eubcontractora.

Printed in the United States of Americe. To obtain coples of thle document, contact: Document Control Senvicas, P.O. Box 950, Mailetop H6-08, Richland WA 90352, Phone (500) 372-2420; Fax (500) 376-4630.
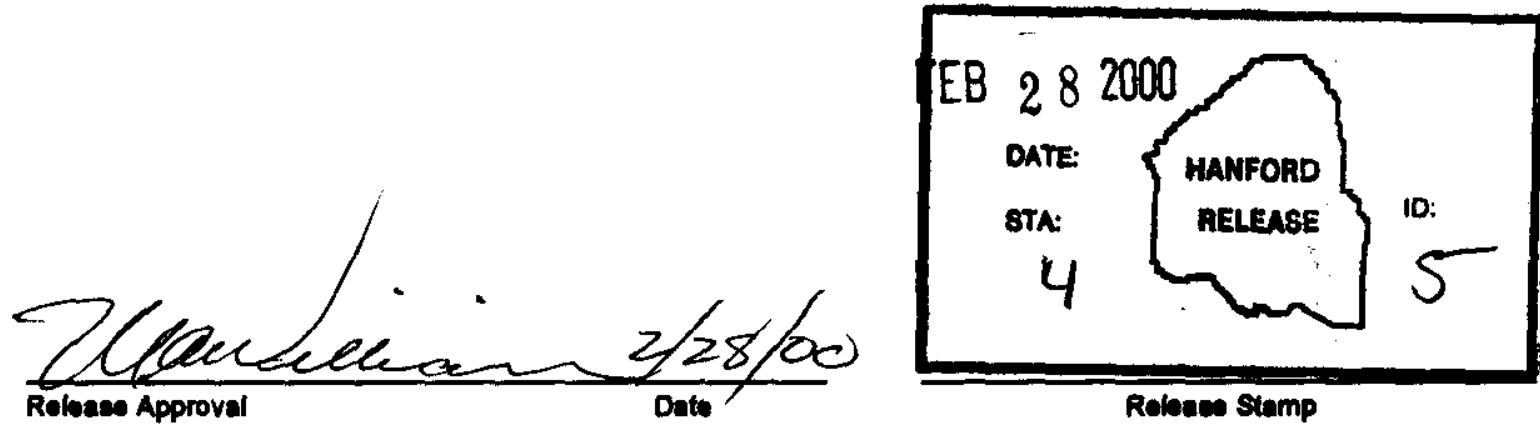

Roloras Stamp 


\section{OPERATIONAL TEST REPORT (OTR) FOR U-103 PUMPING, INSTRUMENTATION AND CONTROL (PIC) SKID}

\section{PURPOSE}

The purpose of this test report is to document the operational test results and conclusions from the completed Operational Test Procedure (OTP-200-004 Rev. A16) that was performed on PIC Skid U-103. IS PIC Skid Configuration Drawing H-2829998 provides traceability for U-103 PIC skid hardware, software, and test documentation

\section{SCOPE}

The scope of this operational test included testing of system parameters and functions. The systems checked are listed in Section 2.1 of the OTP and include process instrumentation, System electrical, process air, water drip and more. The attachment to this test report is a copy of the actual test that was preformed. The test was conducted by Interim Stabilization and witnessed by the Cognizant Engineer.

\section{TEST RESULTS}

The test was completed and signed off on September 25, 1999. There were four test exceptions noted during the performance of the test. The first exception documented that section 5.3 through 5.10 were not performed during the OTP. Section 5.3 through 5.10 were done in their entirety during the ATP for PIC skid " $K$ " (ATP \# HNF-4277) and that all exceptions to the ATP specified in HNF-4277 were satisfactory resolved.

The second exception (OTP sections 5.11) documented that the leak detectors in SY02A pump pit and SYA/SYB valve pits failed the OTP test. The OTP requires the leak detectors to shutdown the U103 PIC skid. There is no data communication between S/SY and U farms. The resolution was to accept "As Is" (the leak detector function properly, i.e. detects leaks), however the condition is not sensed by U103 PIC skid. Until the condition is resolved and the SY/S Farm leak detector interlocks skid shut down of U103, an operator will be stationed in SY/S Farm to notify U farm operator of a leak condition in 02A, SA, and SB valve pits. This will allow the operator to take the appropriate action. Reference operating procedure TO-505-103.

The third exception (OTP section 4.2.12) documented that all ECNs to operate the pump were not signed off work complete. All work to operate (Simulate) pump was complete. The heat trace work was not complete. Resolution of exception will have ECNs signed off work complete HT completion of OTP. 
The fourth exception (OTP section 5.1.11.1, 2, 3) documented that the weight factor (SPG) was reading 242, test designed to measure the parameter without dip tubes connected. Resolution involved disconnecting dip tubes, running test (parameters read properly) and then reconnection dip tubes.

\section{CONCLUSION}

The test demonstrated the proper operation of U-103 PIC Skid. All test exceptions were resolved and documented in the OTP exceptions records attached to the OTP.

\section{ATTACHMENT}

Attached to this report are Appendix A and Appendix B. Appendix A is a copy of the completed and signed OTP. Appendix B is a copy of the software printout.

Note: The OTP in the work package WS-99-00146 for U-103 was missing the attached software printout. Appendix B is a copy of the U-103 software printout released in HNF-4770 at the completion of the OTP. 


\section{OPERATIONAL TEST PROCEDURE FOR 6000 SERIES PUMPING AND INSTRUMENTATION CONTROL SKIDS \\ AND INSTRUMENTATION CONTROL SKIDS}

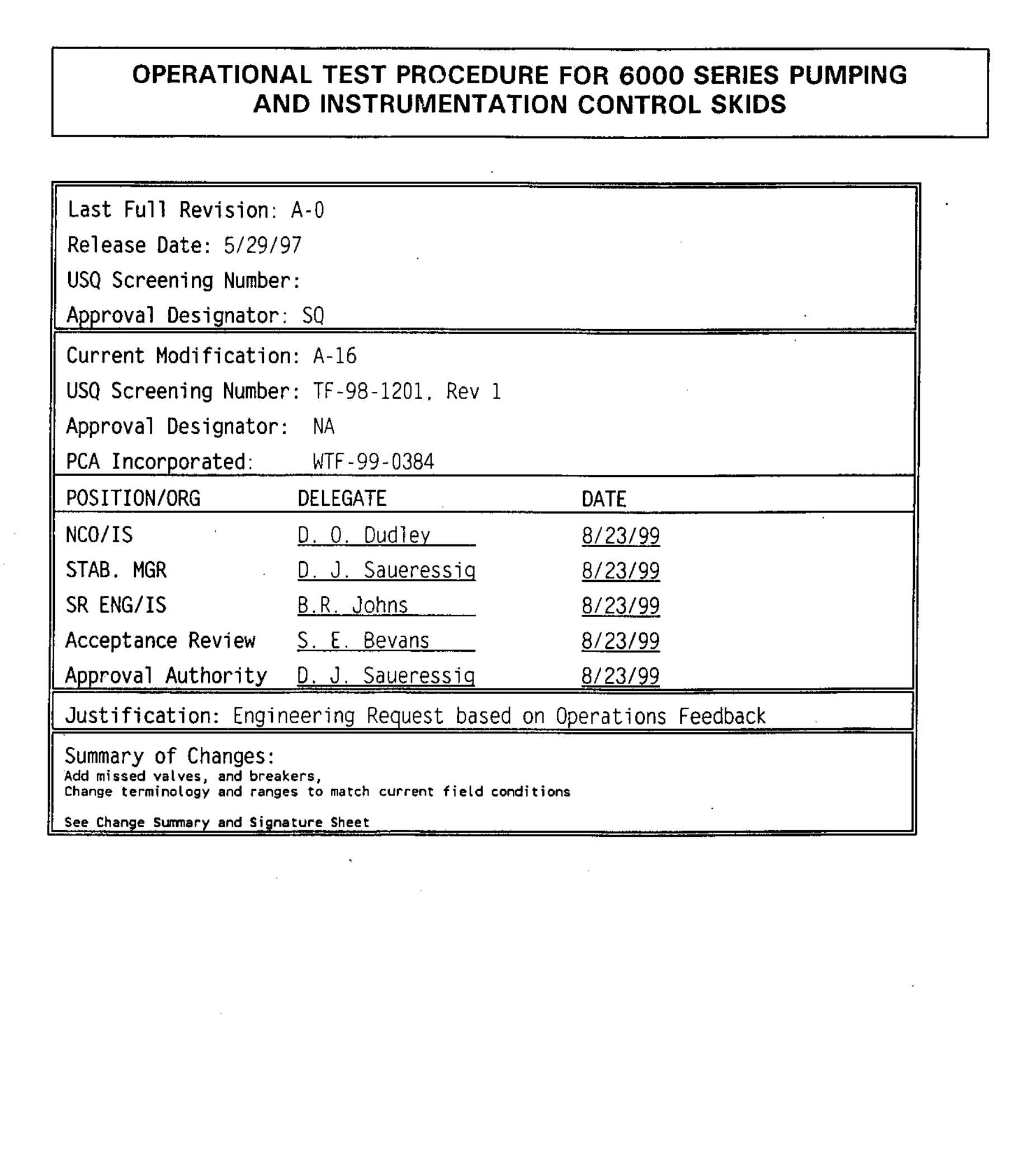

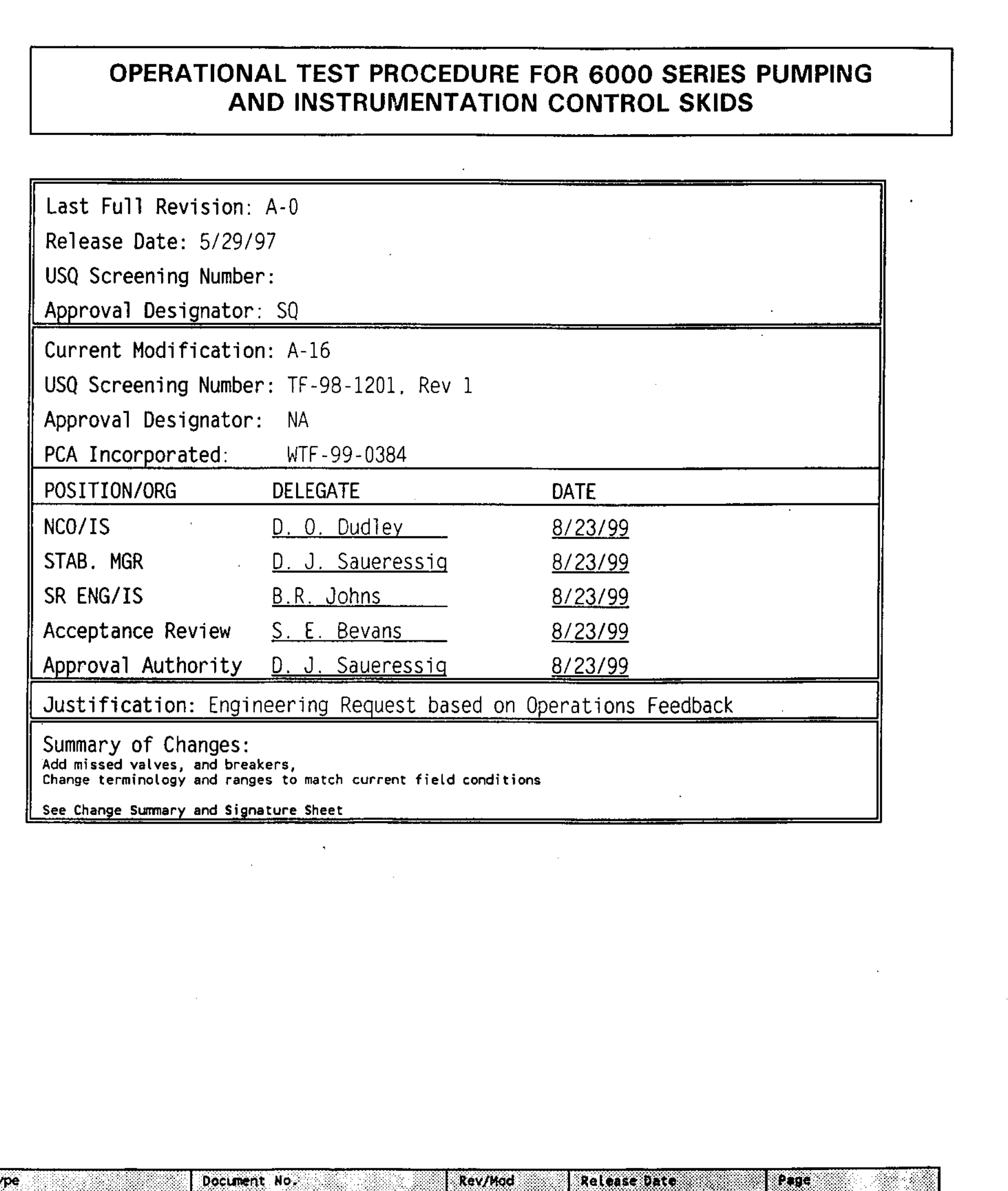




\section{TABLE OF CONTENTS}

1.0 PURPOSE

2.0 INFORMATION

2.1 SCOPE

2.2 TERMS AND DEFINITITIONS

2.3 RESPONSIBILITIES

2.4 REFERENCES

2.5 SAFETY

2.6 RADIATION AND CONTAMINATION CONTROL

2.7 QUALITY ASSURANCE

2.8 GENERAL INFORMATION

2.9 LIMITS AND PRECAUTIONS

3.0 RECORDS

4.0 PREREQUISITES . . . . . . . . . . . . . . . . . . . . . . . . . . . 9

5.0 PROCEDURE

5. I PUMPING AND INSTRUMMENTATION CONTROL ŚKID ELECTRICAL AND PROCESS AIR POWER-UP

5.2 PUMPING AND INSTRUMENTATION CONTROL SKID WATER DRIP SYSTTEM

5.3 VERIFY DATA TABLE ACCESS MODULE AND OPERATOR CONTROL STATION ANALOG INPUT SIGNALS

5.4 VERIFY DATA TABLE ACCESS MODULEE AND OPERATTOR CONTROL STATION DISCRETE SIGNAL INPUTS

5.5 VERIFY DATA TABLE ACCESS MOOULE் AND́ OPERATOR CONTROL STATION MONITOR/ALARM FUNCTIONS

5.6 REMOTE SETPOINT CHANGE USING THE OPERATOR CONTROL STATION

5.7 DATA TABLE ACCESS MODULE AND OPERATOR CONTROL STATION DIAPHRAGM OPERATED VALVE AUTOMATIC/MANUAL OPERATION

5.8 JET PUMP FLOWMETER OPERATION

5.9 JET PUMP VALVING INTERLOCK FOR THE JET PUMP

5.10 OPERATOR CONTROL STATION JET PUMP SHUTDOWN TEST

5.11 LEAK DETECTION INTERLOCK CHECK

5.12 SHUTDOWN CIRCUITRY CHECK

5.13 SOFTWARE DOCUMENTATION

OPERATIONAL TEST PROCEDURE EXCEPTION LOG

OPERATIONAL TEST PROCEDURE EXCEPTION RECORD . . . . . . . . . . . . . 90

OPERATIONAL TEST PROCEDURE ACCEPTANCE RECORD . . . . . . . . . . . . 9:

PROCEDURE PERFORMER SIGNATURE SHEET . . . . . . . . . . . . . . . . . . 92

PROCEDURE HISTORY SIGNATURE SHEET . . . . . . . . . . . . . . . . . . . . 93

\begin{tabular}{|c|c|c|c|c|}
\hline TyPOERENCE & OTP-200-004 & Revimoding & $\begin{array}{l}\text { Reticast dater } \\
8 / 23 / 99\end{array}$ & Prof of 108 \\
\hline HNF-5820, & & A-2 & & \\
\hline
\end{tabular}




\subsection{PURPOSE}

This Operational Test Procedure (OTP) will test and verify that the equipment required for Saltwell pumping of specified tank meets the specified Functional Requirements. Safety Requirements. Radiological Requirements, Operations Requirements, and provides a record of the functional test results. The systems/functions that will be tested are listed in the Scope section that follows.

\subsection{INFORMATION}

\subsection{SCOPE}

The following systems will be tested by this Operational Test Procedure:

- Process Instrumentation and Control System Electrical and Process Air System

- Process Instrumentation and Control System Water Drip System

- Weight Factor and Specific Gravity System

- Diaphragm Operated Valve Automatic and Manual Operation

- Jet pump Flowmeter Operation

- Water Tank Level Transmitter

- Jet pump Heat Trace

- Leak Detection Interlock

- Jet Pump Valving Interlock

- Safe Shutdown Circuit

- Flammable Gas Monitor Interface

- Exhauster Interface

- Receiver Tank Interlocks

\section{.}

HNF-5820, Rev, 0
Document No.

OTP-200-004

Revimod

A- 16 


\subsection{TERMS AND DEFINITIONS}

2.2.1 LCV - Level Control Valve

2.2.2 GPM - Gallons $\underline{\text { Per Minute }}$

2.2.3 IA - Instrument Air

2.2.4 LDE - Leak Detection Element

2.2.5 OCS - Qperator Control Station

2.2.6 PRV - Pressure Relief Valve

2.2.7 SGI - Specific Gravity Indicator

2.2.8 WFIE - Weight Eactor Instrument Enclosure

\subsection{RESPONSIBILITIES}

2.3.1 Quality Control is responsible for:

- Witnessing and signing steps as identified in Operational Test Procedure.

- Verifying that the procedure sections were performed correctly.

2.3.2 Test Director is responsible for:

- Providing the equipment found in step 4.1 of this procedure.

- Recording equipment status and data per this procedure.

- Conducting pre-job planning meeting as necessary.

- Conducting pre-job system walkdown.

- Scheduling/rescheduling of the test as required.

- Recording data, exceptions and other notes as required.

2.3.3 Engineering personnel are responsible for:

- Providing technical support during testing.

- Providing programming support during testing.

- Forcing data in Programmable Logic Controller program during testing. 


\subsection{RESPONSIBILITIES (Cont.)}

2.3.4 Maintenance personnel are responsible for:

- Providing assistance during testing.

2.3.5 Operations personnel are responsible for:

- Performing valving manipulations on Pumping and Instrumentation Control Skid Systems and Test equipment.

- Starting, stopping, and controlling equipment related to Saltwell operations.

- Controlling and monitoring parameters from the Data Table Access Module, or Operator Control Station.

2.3.6 Health Physics personnel are responsible for:

- Ensuring RWP requirements are met during field portion of testing.

- Surveying tools and equipment out of the Farm.

- Providing guidance to craft personnel in maintaining good health physics practices.

\subsection{REFERENCES}

2.4.1 The following documents were used to write or are referenced in this procedure:

- HNF-PRO-079, "PRE-JOB SAFETY PLANNING"

- WHC-IP-1026 APPX L, "ENGINEERING PRACTICES GUIDELINES"

- H-14-100538 Rev 0. SALTWELL JET PUMP

- H-14-100542 Rev 0. SALTWELL JUMPER ASSEMBLY

- H-2-85621 ReV 0, INSTRUMENT AIR AND WATER SYSTEM DETAILS

- H-2-85625 ReV 0. INSTRUMENTATION WEIGHT FACTOR ENCLOSURE ARRANGEMENT

- H-2-85626 ReV 0. PUMPING AND INSTRUMENTATION CONTROL SKID

- H-14-023960 ReV 0. SALTWELL CONTROL EQUIPMENT (SALW) O\&M SYSTEM P\&ID

- JOHNSON YOKOGAWA ADMAG AM SERIES VENDOR INFORMATION

- FOXBORO 823 DP SERIES ELECTRONIC DIFFERENTIAL PRESSURE CELL VENDOR INFORMATION

- T0-060-085, OPERATE THE PORTABLE 500 CFM EXHAUSTER FOR TANK 241-A-161 SALTWELL PUMPING

- Controlotron System 990 Uniflow Universal Clamp-On NEMA Flowmeter Vendor Field Manual

\begin{tabular}{|c|c|c|c|c|}
\hline REFER & OTP-200-004 & A-16. & $\begin{array}{c}\text { Releass bater } \\
8 / 23 / 99\end{array}$ & $\frac{10}{5 \cdot 0}$ \\
\hline
\end{tabular}




\subsection{SAFETY}

Warning - 120 VAC energized circuits and leads will be encountered during test if access to Programmable Logic Controller input/output terminals or serial communication port is required at any time. Observe appropriate electrical precautions as directed by HNFPRO-088. Electrical Work Safety.

Warning - Circuit boards are energized. Terminal strips in the Instrument Enclosure have 120 VAC exposed leads. Use appropriate electrical precautions as directed by HNF-PRO-088. Electrical Work Safety.

Warning - Energized circuits and leads are contained inside the cabinet Observe appropriate electrical precautions. Comply with HNFPRO-088. Electrical Work Safety.

2.5.1 Work will be performed in this Operational Test Procedure on energized circuits.

2.5.2 The following administrative procedures control work performed in this procedure:

- Building Emergency Plan. WHC-IP-0263-TF

- Industrial Hygiene Manual. WHC-CM-4-40

- HNF-PRO-074. Safety Responsibilities

- Tank Farm Health and Safety Plan (HASP), WHC-SD-WM-HSP-002

\subsection{RADIATION AND CONTAMINATION CONTROL}

2.6.1 Health Physics Technician assistance is required in accordance with Radiation Work Permit.

2.6.2 The following administrative procedures control work performed in this procedure:

- Hanford Site Radiological Control Manual (HSRCM)

2.6.3 The test shall be STOPPED and the Shift Manager immediately notified. if radiation levels significantly increase as determined by a radiation monitor.

2.6.4 Work in Radiological Areas will be performed using a Radiation hork Permit, following review by Radiological Control per the ALARA program (HNF-IP-0842, Vol 7. Section 1.1).

\begin{tabular}{|c|c|c|c|c|}
\hline TPO RE ERENOE. & gocument ro & Reymodil. & Relcuse orto 8123199 & 9ope of 108 \\
\hline
\end{tabular}




\subsection{QUALITY ASSURANCE}

Ensure that the test(s) are performed per the procedure. The Quality control Inspector shall sign and date each procedure section verifying the data obtained. and verifying that the procedure section has been performed correctly.

\subsection{GENERAL INFORMATION}

2.8.1 After completion of Sections 5.1 and 5.2. subsequent sections may be performed out of order, as directed by the Test Director.

2.8.2 All entries recorded in this procedure shall be made in black ink.

2.8.3 Editorial changes required to this Operational Test Procedure may be made per the Procedure Change Authorization method by the Test Director and Cognizant Engineer as long as they do not impact personnel safety, or operational facility safety function or performance: and will not compromise or influence the test data.

2.8.4 Any non-conformance of the instrumentation or unexpected results during testing shall be logged in the Operational Test Procedure EXCEPTION LOG and thoroughiy documented on a Operational Test Procedure EXCEPTION RECORD.

2.8.5 Do not perform any part of this procedure on faulty equipment. If faulty equipment is discovered. STOP the execution of that section of this procedure and resolve the problem and/or continue with a different section.

2.8.6 If the performance of this procedure is suspended for any reason. ensure the equipment is left in a safe and de-energized state as necessary.

2.8.7 This procedure DOES NOT contain any separate data/verification sheets. Verification of procedural steps and validity of the data is incorporated into the specific section.

2.8.8 If performance of this procedure is suspended for any reason and if necessary, ensure the requirements of the Lock and Tag system are met before leaving the test site.

2.8.9 A Job Hazard Analysis form will be used in conjunction with the pre-job safety meeting form when any unusual hazards are identified. The PRE-JOB MEETING FORM will be used to document all attendees.

\begin{tabular}{|c|c|c|c|c|}
\hline nes & $\begin{array}{l}\text { pocment po: } \\
\text { OTP-200-004 }\end{array}$ & $\begin{array}{l}\text { Revpod } \\
\text { A-16 }\end{array}$ & $\begin{array}{r}\text { Release poto } \\
8 / 23 / 99\end{array}$ & ? 7 \\
\hline
\end{tabular}




\subsection{GENERAL INFORMATION (Cont.)}

2.8.10 Tests interrupted due to work breaks, personnel support, faulty equipment or other reasons may require performing equipment manipulations such as valving, power down or alarm acknowledgement in order to leave the equipment in a safe condition. The Test Director may deviate from test steps in order to assure safe equipment configuration. Configuration shall be noted so the equipment may be restored at the resumption of testing. Shift Management shall be kept apprised of test status and equipment condition.

2.8.11 Acknowledge applicable alarms per Test Director.

2.8.12 Sections 5.1 through 5.9 of this procedure are generally performed in the shop prior to equipment placement in the field. Daily release requirements through the Shift office must be met for field portions of testing.

2.8.13 Section 5.12 is only performed for Facility Group 2 tank 241-A-101 installation only. All other Facility Group 2 and 3 tanks undergoir.g saltwell operational testing will omit this section.

2.8.14 In some instances, such as Emergency Pumping Skid testing. the Operator Control Station will be untested or not required. Test sections 5.6 and 5.10 will not be performed. Blanks represent ing CiS data shall be completed with an "NA" in other test sections.

\subsection{LIMITS AND PRECAUTIONS}

DO NOT perform any tank intrusive work without the express authorization of the Shift Manager.

\begin{tabular}{|c|c|c|c|c|}
\hline REF & poerment lo. & A-16 & Releast bate $8 / 23 / 99$ & 8 of 108 \\
\hline
\end{tabular}




\subsection{RECORDS}

3.1 The completed Working Copy of this procedure, including all exception logs and exception records generated by this procedure, will be kept as permanent records.

3.2 This procedure is designed to be re-usable for many skid installations. Each skid will replace the asterisk (*) in device names used throughout this procedure.

3.3 RECORD the following information for this procedure:

Tank Number:

Skid Designator: SALW' $600 / K$

3.4 RECORD the following information or "NA" if an Operator Control Station is not tested.

Operator control Station Location (building number): $0 C S$ Computer chedkd PerHNF-AZTY.

\subsection{PREREQUISITES}

NOTE - Equipment shall be available before the step associated with that piece of equipment.

4.1 The following supplies shall be available at the work place:

- Volt/onm meter (VOM): Portable, 0-600 volts ac. $\pm 2 \%$ accuracy.
Calibration No.
$\wedge 1-A$
Expiration Date
$\wedge A$
QC $N \mathbb{A}$

- Transmation current (milliamp) simulator or equivalent

Calibration No. N $M \mid \mathcal{A}$ Expiration Date NAA

QC N/N

- Manometer - minimum range 0-500" water gauge. Must have a read out of variable test pressure.

Calibration No. $N / A$

- Manometer - minimum range 0-50" water gauge. Must have a read out of variable test pressure.

Calibration No. N/A Expiration Date

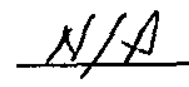

oc N/A

\begin{tabular}{|c|c|c|c|c|}
\hline TPP RE PERENCE. & 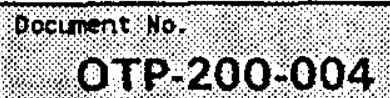 & ReV/Mod: 1.16 & 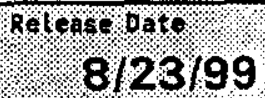 & 906108 \\
\hline
\end{tabular}




\subsection{PREREQUISITES (Cont.)}

- Jumper Test Assembly PI-2 (suction) pressure gauge (Required for shop runins only - NA lines for field only OTPS)

Calibration No. NNA Expiration Date NAD OCNN

- Jumper Test Assembly PI-1 (discharge) pressure gauge (Required for shop run-ins only - NA lines for field only OTPS)

Calibration No. N/A Expiration Date N/A OC N/X

- Flowmeter Calibrator (Required for Brooks flowmeters only - NA lines for skids with Yokogawa flowmeters)

Calibration No. NAD Expiration Date NAD OC NAD

- Saltwel1 Jet pump Jumper (see H-14-100725 Sheet 18)

- Rotameter or Flowmeter $N$ A

- Jumper Test Assembly NAd

- 2 way radios for communication between Tank Farm and local control room

- $480 \mathrm{~V} 3$ Phase Power Source

- Controlotron 995T Control and Display Unit NAN

NOTE - Test sections may commence prior to assembly of all test equipment. Test Director is responsible to assure all equipment necessary for a given section is available.

SEE Test 4.2 The following conditions must be met before this test may commence:

IXCENTRON

$\#$ H
4.2 .1

The Jet Pump Jumper and Jumper assembly have been placed on the pump

recirculation apparatus.

4.2.2 The Pumping and Instrumentation Control Skid water tank and run-in tank have been adequately fjlled for testing,

SAW WATER TAWK hAS been adeq alately filled.

4.2.3 The Jet Pump Jumper AND Jumper Assembly have been electrically AND pneumatically connected to the Pumping and Instrumentation Control Skid. 


\subsection{PREREQUISITES (Cont.)}

4.2.4 A pre-job safety meeting has been held before performing this procedure in accordance with WHC-IP-0842. Vol V Section 4.1. PRE-JOB SAFETY MEETING FORM.

4.2.5 The Pumping and Instrumentation Control Skid has been grounded in preparation for shop testing.

$$
\text { estivg in field. }
$$

TEsT Excoptiont. 2.6

Test gauges AND rotameter have been installed in correct locations as indicated by the Test Director. Test gages and rotor

meti. not noeded fix sectionctested.

4.2.7 Ensure the following Pumping and Instrumentation Control Skid Valves are OPEN prior to starting this OTP

$\checkmark$ SALW-V-6035* (equalizing) $\bigvee$ SALW-V-6036* (equaling)

4.2.8 ENSURE the following Pumping and Instrumentation Control Skid valves are CLOSED prior to starting this Operational Test Procedure:

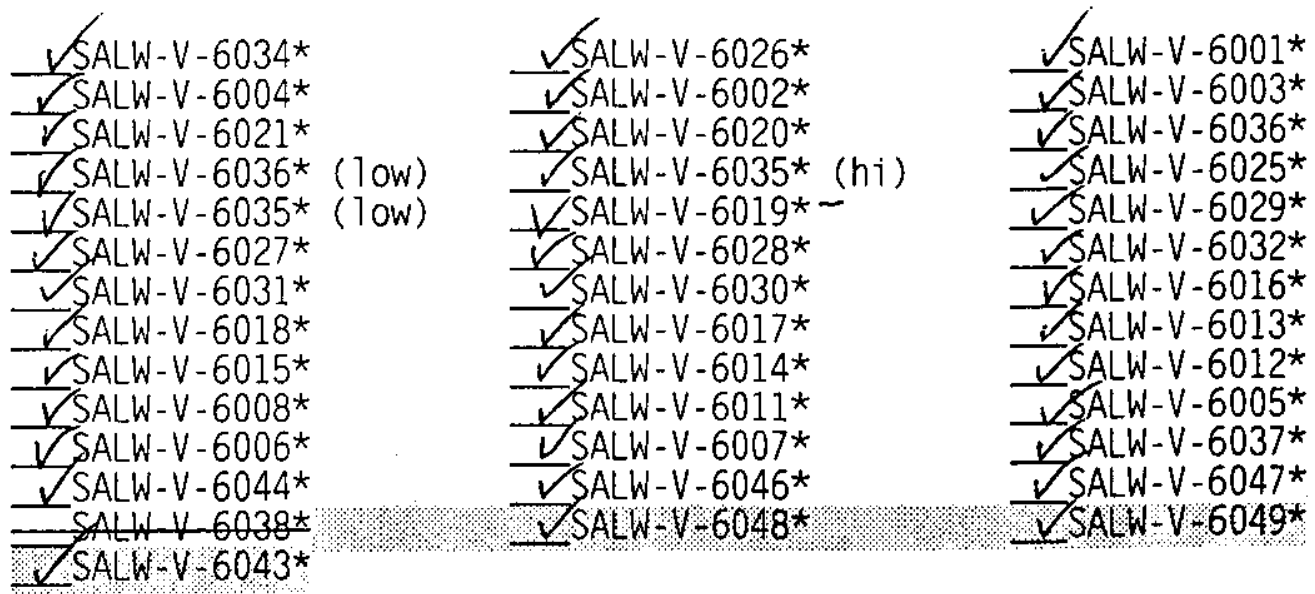

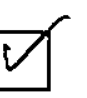




\subsection{PREREQUISITES (Cont.)}

4.2.9 ENSURE the following Pumping and Instrumentation Control Skid circuit disconnects and breakers are OPEN (OFF) prior to starting this Operational Test Procedure. Refer to H-2-85327. Sheet 7 for circuit breakers.

$\frac{\sqrt{\text { SALW-DS }-6002^{*}}}{\sqrt{\text { SALW-DS-6005* }}} \quad \underline{\text { SALW-DS-6003* }} \simeq$ SALW-DS-6004*

NOTE - The following breakers are located in SALW-DP-6001*.

$\checkmark$ Breaker "MAIN" $\quad \checkmark$ Breaker 2

$\checkmark$ Breaker $1 \quad \checkmark$ Breaker 4

Breaker $3 \quad \checkmark$ Breaker 6

$\checkmark$ Breaker 5 Breaker 8

$\checkmark$ Breaker 7 Breaker 10

$\checkmark$ Breaker 11 : $:$ : $:$ Breaker 14

$\checkmark$ Breaker 13

4.2.10 A printed copy of Ladder Logic and Alarm Table for the Pump Instrumentation and Control Skid is available at the work site. Copies may be kept outside of Radiological areas until necessary.

4.2.11 All personnel initialling or signing this procedure must also enter signature/initials on the PROCEDURE PERFORMER SIGNATURE SHEET.

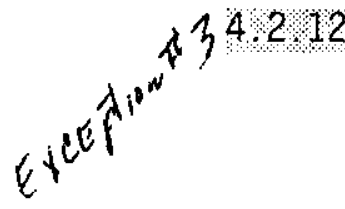

Verify that all appl 1 cable ECNs are slgned off as work complete. All necersary scus to osserde pump (sinnulated) have beer compitefed at completfare of ore all arplecable ECN's will bejigned off as work complete

\begin{tabular}{|c|c|c|c|c|}
\hline REF & $\begin{array}{l}\text { Document No } \\
\text { OTP-200-004 }\end{array}$ & Revplood 16 & 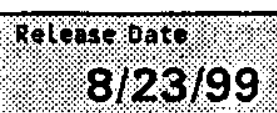 & 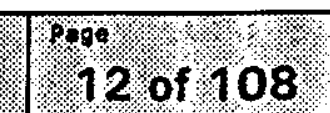 \\
\hline
\end{tabular}




\subsection{PREREQUISITES (Cont.)}

NOTE - Verification of instrument calibration must be performed before the step associated with that instrument.

4.3 Verify the current calibration. Record the calibration date and calibration due date on the table below.

\begin{tabular}{|c|c|c|}
\hline INSTRUMENT & $\begin{array}{l}\text { CALIBR/FUNCT CHECK } \\
\text { DATE }\end{array}$ & NEXT DUE DATE \\
\hline & $x / y+4 y \leq j=q$ & $8=-\infty$ \\
\hline SALW-PS - $6004^{*}$ & $8 \cdot 5 \cdot 99$ & 8.5 .00 \\
\hline SALW-WFT- $6002^{*}$ & $8 \% 16 \cdot 99$ & $8 \cdot 00$ \\
\hline SALW-LT-6003* & s. $9-9 q$ & $8-00$ \\
\hline SALW-SGT-6001* & $8-10.49$ & $8 \cdot c 0$ \\
\hline SALW-CONV-6001* $\$ A L W-\angle Y-6001 *$ & $8-10-44$ & 8. .0 \\
\hline SALW-FQIT-6001* & $5.13-99$ & $\delta \cdot a$ \\
\hline SALW-PI - 6006* & $8 \cdot 10-99$ & $8 \cdot 00$ \\
\hline SALW-PI - $6001^{*}$ & $8-10-99$ & $8-00$ \\
\hline SALW-PI - 6005* & 8.10 .44 & $8 \cdot 00$ \\
\hline SALW-FI - $6001^{*}$ & $8.5-94$ & 8.500 \\
\hline SALW-PI - 6002* & $8-10-99$ & $8-00$ \\
\hline SALW-PI - $6003^{*}$ & $8 \cdot 10-49$ & $8-00$ \\
\hline SALW-PI - 6004* & $8 \cdot 10-99$ & $8 \cdot 00$ \\
\hline SALW-PI-6007* & $8-10-99$ & $8.0 z$ \\
\hline SALW-PI - $6008^{*}$ & 8.10 .99 & 8.00 \\
\hline
\end{tabular}

\begin{tabular}{|c|c|c|c|c|}
\hline "YPP' REFERENCE & Pocinent & Revirod 1.16 & Roters & Poger of 108 \\
\hline
\end{tabular}




\subsection{PREREQUISITES (Cont.)}

4.4 Test Director VERIEY that section 4.0 has been completed by SIGNING below.

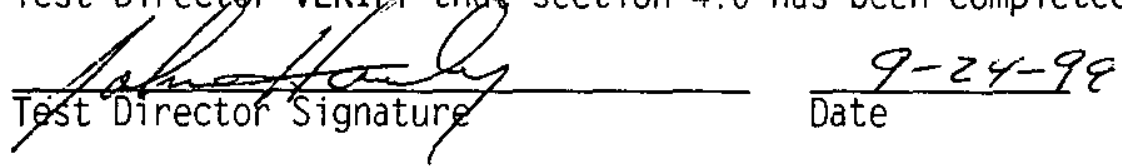

4.5 Quality Control Inspector VERIFY that section 4.0 has been completed by SIGNING below.

$$
\begin{aligned}
& \frac{\text { Kem W }}{\text { Quality Control Inspector Signature }} \frac{9 / 2 y / 99}{\text { Date }} \\
& \text { * Set excerion \#/) } 3 \text { kenglaylsi }
\end{aligned}
$$

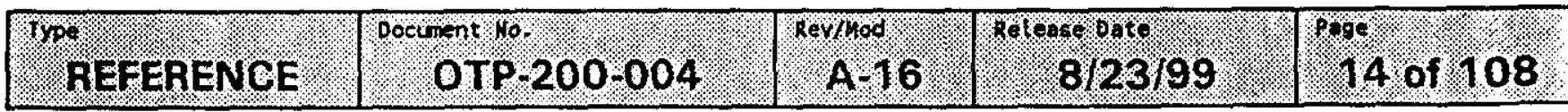




\subsection{PROCEDURE}

NOTE - This Operational Test Procedure will be used for more than one skid. An asterisk $\left(^{*}\right)$ is used to identify the skid LETTER.

NOTE - All personnel performing this procedure. Who will be initialing and signing the procedure. shall enter their printed name, signature and initials on the PROCEDURE PERFORMER SIGNATURE SHEET.

5.1 PUMPING AND INSTRUMENTATION CONTROL SKID ELECTRICAL AND PROCESS AIR POWER-UP

5.1.1 ENERGIZE the Pumping and Instrumentation Control Skid by CLOSING the following DISCONNECT SWITCHES in the order found below:

\begin{tabular}{|l|c|}
\hline \multicolumn{1}{|c|}{ DISCONNECT SWITCH } & ENERGIZED \\
\hline SALW-DS-6002* & $(\Omega)$ \\
\hline SALW-DS-6003* & $\checkmark$ \\
\hline SALW-DS-6004* & $\checkmark$ \\
\hline SALW-DS-6005* & $\checkmark$ \\
\hline
\end{tabular}

\begin{tabular}{|c|c|c|c|c|}
\hline REFEF & $\begin{array}{l}\text { Document No } \\
\text { OTP-200-004 }\end{array}$ & $\begin{array}{c}\text { Revplod } \\
\text { A-16 }\end{array}$ & 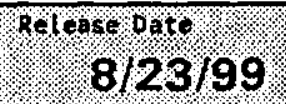 & 15 of 108 \\
\hline
\end{tabular}


5.1 PUMPING AND INSTRUMENTATION CONTROL SKID ELECTRICAL AND PROCESS AIR POWER-UP (CONT.)

NOTE - The following circuit breakers are located in SALW-DP-6001* "SALW SKID DIST PNL".

5.1.2 ENERGIZE the Pumping and Instrumentation Control Skid by CLOSING the following Circuit Breakers in the order found below:

\begin{tabular}{|l|l|}
\hline \multicolumn{1}{|c|}{ DISCONNECT SWITCH } & \\
\hline "MAIN" & \\
\hline 7. (WEIGHT FACTOR INSTRUMENT ENCLOSURE) & \\
\hline 3, (LEAK DETECTION/HEAT TRACE) & \\
\hline 8, (WATER TANK HEATER) & \\
\hline 5. (INSTRUMENT ENCLOSURE [PLC]) & \\
\hline 4, (AIR COMPRESSOR CABINET HEATER \& [1] \\
RECEPTACLE)
\end{tabular}

\begin{tabular}{|c|c|c|c|c|}
\hline TYP' REFERENCE & 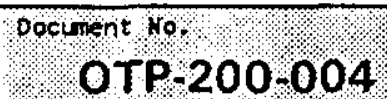 & Reviod 16 & Relorse oato $8123 / 99$ & fore. 16 of 108 . \\
\hline
\end{tabular}




\subsection{PUMPING AND INSTRUMENTATION CONTROL SKID ELECTRICAL AND PROCESS AIR POWER-UP (CONT.)}

5.1.3 ACKNOWLEDGE any initial skid or FGM alarms.

5.1.4 OPEN valve SALW-V-6034* (located in the Air COMP Cabinet).

5.1.5 START air compressor SALW-CMP-6001* "SALW SKID IA COMP" by POSITIONING switch on the SALW-DS-6004* to the HAND or ON position.

5.1.6 VERIFY that Air Compressor starts and builds up pressure AND shuts off at 86 to 94 psig. as indicated by pressure gauge SALW-PI-6006* (AIR DRYER INLET PRESS)

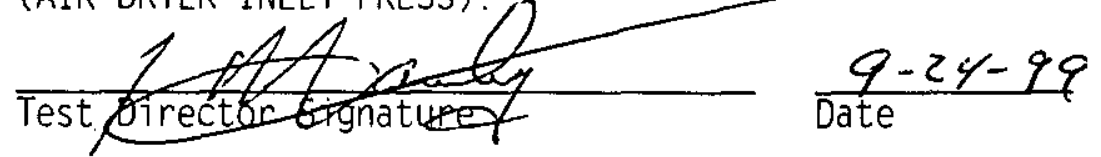

5.1.7 VALVE in air to the Pumping and Instrumentation Control Skid water Tank by SLOWLY PERFORMING the following (Refer to H-14-023960 Sheet 1):

5.1.7.1 SLOWLY OPEN valve SALW-V-6025* (located in the air compressor cabinet).

5.1.7.2 SLOWLY OPEN vaive SALW-V-6027* (located near the water tank).

5.1.7.3 SLOWLY OPEN valve SALW-V-6028* (located near the water tank).

5.1.7.4 ADJUST Pressure Regulator Valve SALW-PCV-6006* to 30 psi ( \pm 3 psig) as indicated by pressure gauge SALW-PI-6008* (WTR TK PRESS). 


\subsection{PUMPING AND INSTRUMENTATION CONTROL SKID ELECTRICAL AND} PROCESS AIR POWER-UP (CONT.)

5.1.8 VALVE IN air to SALW-PNL-6002* (WFIE Cabinet) by PERFORMING the following (Refer to H-14-023960 Sheet 1):

5.1.8.1 SLOWLY OPEN valve SALW-V-6026* (located in the Air Compressor Cabinet).

5.1.8.2 SLOWLY OPEN valve SALW-V-6001*. located in the bottom of SALW-PNL-6002* (WFIE Cabinet).

5.1.8.3 ADJUST pressure control valve SALW-PCV-6001* in SALW-PNL-6002* (WFIE Cabinet) to $20 \mathrm{psi}( \pm 2.5 \mathrm{psi})$ as indicated by the pressure gauge located on the face of the valve.

5.1.8.4 SLOWLY OPEN valve SALW-V-6004*, located in the middle of SALW-PNL-6002* (WFIE Cabinet).

5.1.8.5 SLOWLY OPEN valve SALW-V-6003*. located in the middle of SALW-PNL-6002* (WFIE Cabinet).

5.1.8.6 SLOWLY OPEN valve SALW-V-6005*. located in the bottom left of SALW-PNL-6002* (WFIE Cabinet).

5.1.8.7 SLOWLY OPEN Valve SALW-V-6006*, located in the bottom left of SALW-PNL-6002* (WFIE Cabinet).

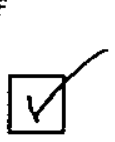

5.1.8.8 SLOWLY OPEN valve SALW-V-6007*. located in the bottom left of SALW-PNL-6002* (WFIE Cabinet).

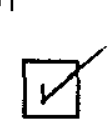

\section{typo \\ REFERENCE}

HNF-5820, Rev. 0
Dociment $\mathrm{No}$

OTP. 200.004

Rex/Hod

A-16

$60100 \% 0$

$8 / 23199$ 


\subsection{PUMPING AND INSTRUMENTATION CONTROL SKID ELECTRICAL AND PROCESS AIR POWER-UP (CONT.)}

5.1.8.9 SLOWLY OPEN valve SALW-V-6002*, located in the bottom left of SALW-PNL-6002* (WFIE Cabinet).

5.1.8.10 SLOWLY OPEN valve SALW-V-6020*. located in the middle left of SALW-PNL-6002* (WFIE Cabinet).

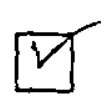

5.1.8.11 SLOWLY OPEN valve SALW-V-6021*. located in the middle left of SALW-PNL-6002* (WFIE Cabinet).

5.1.8.12 SLOWLY OPEN valve SALW-V-6019*. located in the middle left of SALW-PNL-6002* (WFIE Cabinet).

5.1.9 ADJUST the air flow through the diptubes by PERFORMING the followirg:

5.1.9.1 ADJUST flow to dip tubes to $1.5 \mathrm{CFH}( \pm 0.5 \mathrm{CFH}$ ) as indicated by SALW-FIV-6002*.

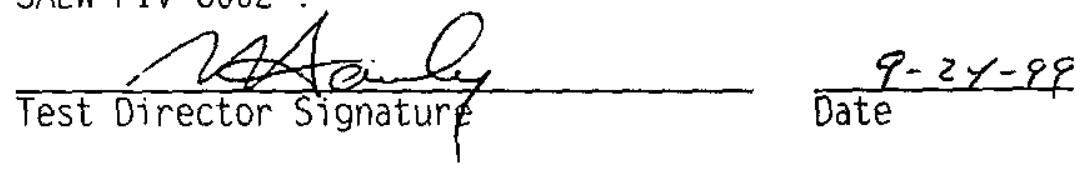

5.1.9.2 ADJUST flow to dip tubes to $1.5 \mathrm{CFH}( \pm 0.5 \mathrm{CFH}$ ) as indicated b: SALW-FIV-6003*.

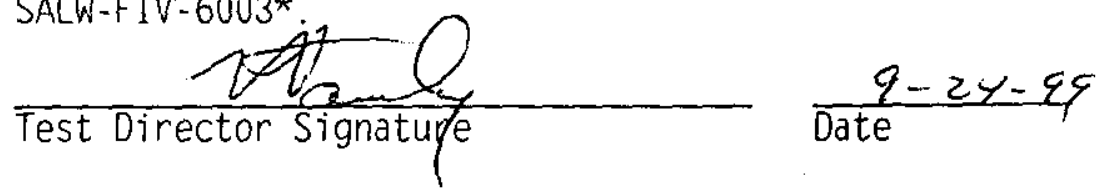

5.1.9.3 ADJUST flow to dip tubes to $1.5 \mathrm{CFH}( \pm 0.5 \mathrm{CFH})$ as indicated b: SALW-FIV-6004*.

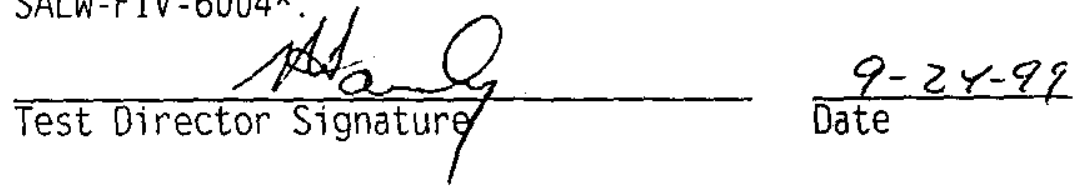

5.1.9.4 ENSURE flows obtained in steps are 211 within $0.25 \mathrm{cfh}$ of each other.

\section{ThPFERENCE :}

HNF-5820, Rev. 0

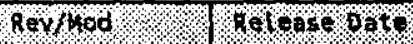

A-16

$8 / 23199$

poe

19 of 108 


\subsection{PUMPING AND INSTRUMENTATION CONTROL SKID ELECTRICAL AND PROCESS AIR POWER UP (CONT.)}

5.1.10 VALVE IN SALW-WFT-6002* AND SALW-SGT-6001* by PERFORMING the following:

5.1.10.1 ENSURE the LOW side AND HIGH side isolation valves, located on SALW-V-6036* in cabinet SALW-PNL-6002* (WFIE Cabinet) are OPEN.

5.1.10.2 ENSURE SALW-WFT-6002* EQUALIZING valve on valve manifold SALW-V$6036^{*}$ in cabinet SALW-PNL-6002* (WFIE Cabinet) is CLOSED.

5.1.10.3 ENSURE the LOW side AND the HIGH side isolation valves. located on SALW-V-6035* in cabinet SALW-PNL-6002* (WFIE Cabinet) are OPEN.

5.1.10.4 ENSURE SALW-SGT-6001* equalizing valve on valve manifold SALW-V$6035^{*}$ in cabinet SALW-PNL-6002* (WFIE Cabinet) is CLOSED.

\begin{tabular}{|c|c|c|c|c|}
\hline REFERENCE. & $\begin{array}{l}\text { Doument } \\
\text { OTP }-200-004\end{array}$ & $\begin{array}{l}\text { Revipod } \\
\text { A-16 }\end{array}$ & $\begin{array}{c}\text { Release bort: } \\
8123199\end{array}$ & 20 of \\
\hline
\end{tabular}




\subsection{PUMPING AND INSTRUMENTATION CONTROL SKID ELECTRICAL AND PROCESS AIR POWER UP (CONT.)}

5.1.11 CONFIRM that a signal is present between SALW-PNL-6002* (WFIE Cabinet) Instruments and the Programmable Logic Controller by PERFORMING the following:

Test exceofor 5.1.11.1 VERIFY Weight Factor is approximately 0.0" ( $\left.\pm 0.5^{\prime \prime}\right)$ Water Gauge

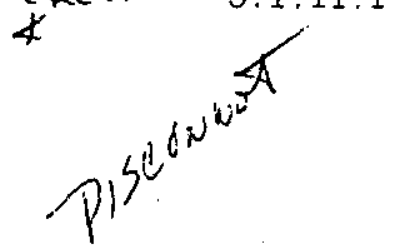

as indicated by Data Table Access Module. If DTAM displays "«<<" indicating less than zero, verify continuity between the transmitter and the Programmable Logic Controller and proceed with the test.

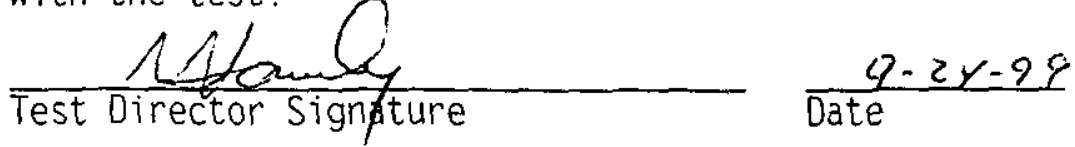

5.1.11.2 VERIFY Specific Gravity is approximately $0.0^{\prime \prime}\left( \pm 0.5^{\prime \prime}\right)$ Water Gauge as indicated by Data Table Access Module. If DTAM displays " $\ll<"$ indicating less than zero, verify continuity between the transmitter and the Programmable Logic Controller and proceed with the tost.

Test Director Signaturg

$$
\frac{9-27.99}{\text { Date }}
$$

5.1.11.3 VERIFY Flow rate is approximately $0.0( \pm 0.5 \mathrm{gpm})$ Gallons Per Minute as indicated by Data Table Access Module. If DTAM

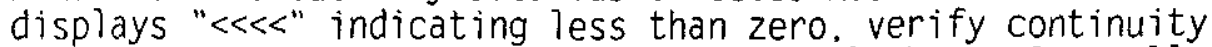
between the transmitter and the Programmable Logic Controlier and proceed with the test.

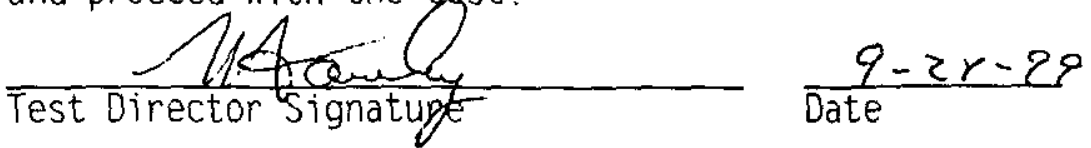

5.1.12 Test Diregtor VGRIFY that section 5.1 is complete by SIGNING below.

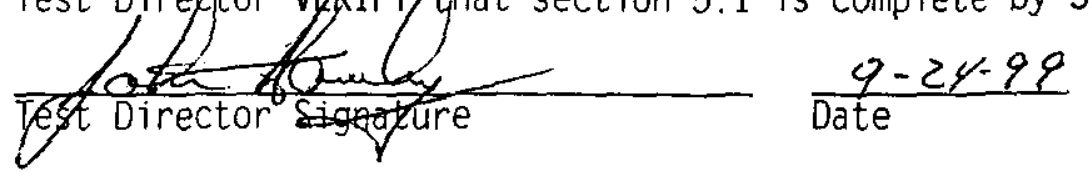

5.1.13 Quality Control Inspector VERIFY that section 5.1 is complete by signing below.

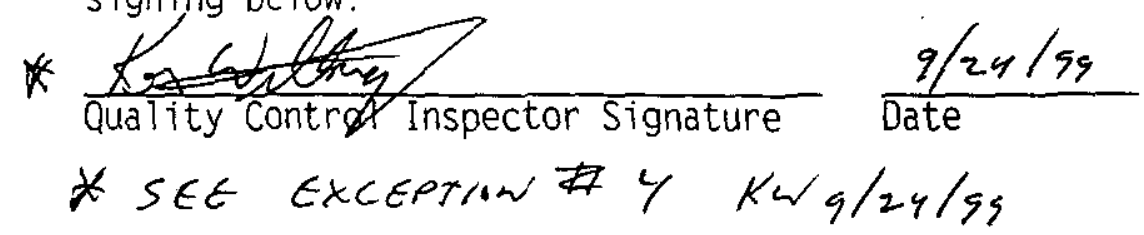




\subsection{PUMPING AND INSTRUMENTATION CONTROL SKID WATER DRIP SYSTEM}

NOTE - If Diptubes are not installed in test area. process air and drip water will be expelled from the side of SALW-PNL-6002* (WFIE (abinet).

5.2.1 If necessary. ATTACH temporary portable hose from diptube outlet to high and medium diptubes from the bottom of the weight factor enclosure. (from valves SAL W-V-6005* and SALW-V-6007*).

- ROUTE the flexible hose to a suitable drain AND SECURE.

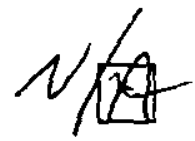

5.2.2 ACTUATE the Dip Tube Drip system by SLOWLY OPENING the following valves:

\begin{tabular}{|c|c|}
\hline VALVES & $\begin{array}{c}\text { OPEN } \\
(\downarrow) \\
\end{array}$ \\
\hline $\begin{array}{l}\text { SALW-V-6018* } \\
\text { located in the bottom right of SALW-PNL-6002* (WFIE Cabinet) }\end{array}$ & \\
\hline $\begin{array}{l}\text { SALW.V-6016* } \\
\text { located in the middle of SALW-PNL-6002* (WFIE Cabinet) }\end{array}$ & \\
\hline $\begin{array}{l}\text { SALW-V-6013* } \\
\text { located in the middle of SALW-PNL-6002* (WFIE Cabinet) }\end{array}$ & \\
\hline $\begin{array}{l}\text { SALW-V-6008* } \\
\text { located in the middle of SALW-PNL- } 6002 * \text { (WFIE Cabinet) }\end{array}$ & \\
\hline
\end{tabular}

\section{CAUTION}

Relief valve (SALW-PRV-6001*) will actuate and relieve pressure at 25 psig.

5.2.3 CAREFULLY ADJUST Pressure Regulator SALW-PCV-6005*. located in the bottom of SALW-PNL-6002* (WFIE Cabinet) to 20 psig ( \pm 2 psig) as indicated by SALW-PI-6001* in the middle of SALW-PNL-6002* (WFIE Cabinet).

5.2.4 ADJUST valve SALW-V-6014* to allow APPROXIMATELY 2 drops/second as indicated by sight glass SALW-FG-6001* ( $\pm 1 \mathrm{drop} / \mathrm{second}$ ).

5.2.5 ADJUST valve SALW-V-6015* to allow APPROXIMATELY 2 drops/second as indicated by sight glass SALW-FG-6002* ( $\pm 1 \mathrm{drop} / \mathrm{second}$ ).

\begin{tabular}{|c|c|c|c|c|}
\hline Troo & Docienent ro. & Requirod & Relearf bar & foge \\
\hline REFERENCE & OTP-200-004 & A-16. & $8 / 23 / 99$ & $2201 / 108$ \\
\hline
\end{tabular}




\subsection{PUMPING AND INSTRUMENTATION CONTROL SKID WATER DRIP SYSTEM (Cont.)}

NOTE - Instrument air to the Diaphragm Operated Valve will remain valved in for testing in subsequent steps.

5.2.6 VALVE OUT the dip tube drip water by SLOWLY CLOSING the following:

\begin{tabular}{|l|c|}
\hline \multicolumn{1}{|c|}{ VALVE } & $\begin{array}{c}\text { CLOSED } \\
(\end{array}$ \\
\hline $\begin{array}{l}\text { SALW-V.6015* } \\
\text { located in the middle of SALW-PNL-6002* (WFIE Cabinet) }\end{array}$ & $\checkmark$ \\
\hline $\begin{array}{l}\text { SALW-V.6014* } \\
\text { located in the middle of SALW-PNL-6002* (WFIE Cabinet) }\end{array}$ & $\checkmark$ \\
\hline $\begin{array}{l}\text { SALW-V-6008* } \\
\text { located in the middle of SALW-PNL-6002* (WFIE Cabinet) }\end{array}$ & \\
\hline $\begin{array}{l}\text { SALW-V-6013* } \\
\text { located in the middle of SALW-PNL-6002* (WFIE Cabinet) }\end{array}$ & \\
\hline
\end{tabular}

5.2.7 Test Director VERIFY that section 5.2 is complete by SIGNING below.

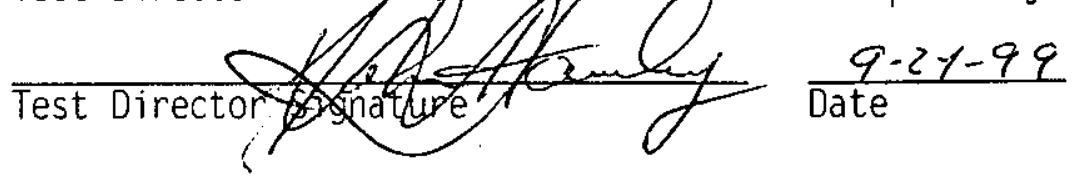

5.2.8 Quality Control Inspector VERIFY that section 5.2 is complete by signing pelow.

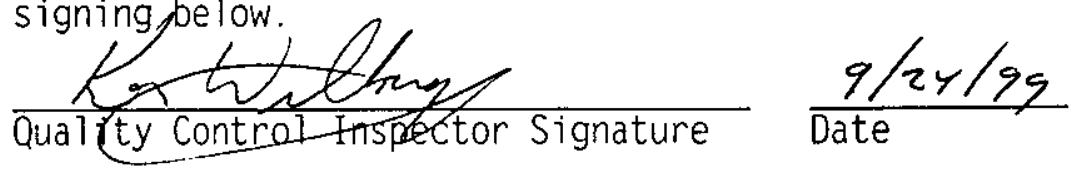


Tcstex 5.3. VERIFY DATA TABLE ACCESS MODULE AND OPERATOR CONTROL STATION

TCs T excePt/OAANALOG INPUT SIGNALS

WATER TANK LEVEL

5.3.1 PREPARE the Water Tank Level Transmitter SALW-LT-6003\% for test signals by PERFORMING the following:

5.3.1.1 ENSURE valve SALW-V-6029*. located in the bottom of SALW-PNL-6003* (WATER TANK ENCL), is CIOSED.

5.3.1.2 ENSURE valve SALW-V-6031* 10 dated in the bottom of SALW-PNL-6003* (WATER TANNENLL), is CLOSED.

5.3.2 CONNECT 0-50" test Manometer/pressure source to the HIGH PRESSURE vent/test port of the lave/ transmitter SALW-LT-6003*.

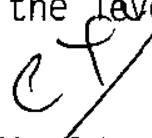

5.3.3 VERIFY the LOW WRESSURE vent/test port of the level transmitter SALW-LT-6003*CSS OPEN to atmosphere.

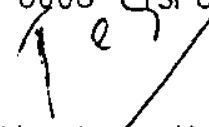

5.3.4 ADJUST, the tost Manometer on the SALW-LT-6003* to a pressure of -25 31"Wetter Gauge ( $\pm 1 ")$.

5.3.5 RECORD the following:<smiles>O=C(O)CC1CCCCC1</smiles>

\begin{tabular}{|c|c|}
\hline $\begin{array}{c}\text { OPERATOR LONTROL STATION } \\
\text { WATER TANK LEVEL } \\
\text { (RANGE: } 28.5 \text { T0 } 33.5 \text { Inches) }\end{array}$ & $\begin{array}{c}\text { DATA TABLE ACCESS MODULE } \\
\text { WATER TANK LEVEL } \\
\text { (RANGE: 28.5 TO } 33.5 \text { Inches) }\end{array}$ \\
\hline
\end{tabular}

\begin{tabular}{|c|c|c|c|c|}
\hline REFEREN & Oocument Wo: $200-004$ & $\begin{array}{l}\text { Reyphod } \\
\text { A-16 }\end{array}$ & \begin{tabular}{|c|} 
Releast pato \\
$8 / 23 / 99$
\end{tabular} & 24 of 108 \\
\hline
\end{tabular}




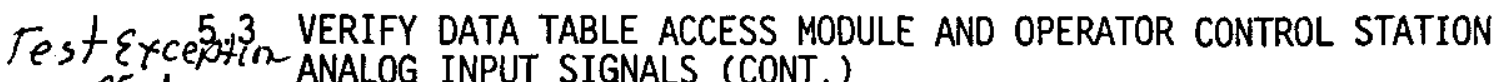
$x 1$

NOTE - Alarm should annunciate between 9.5-11.7" and 10.5-12.7" Water Gauge.

5.3.6 VERY SLOWLY DECREASE the Level Transmitter test Manometer pressure UNTIL the Data Table Access Module "PIC WATER LEVEL LOW" alarm (alarm 9) annunciates.

5.3.7 VERIFY that the Water Tank Low Lal a Jarm is displayed at the Operator Control Station.

5.3.8 ACKNOWLEDGE the Water TanklLon Level alarm at the Operator Control Station and at the Data tabye Access Module.

5.3.9 OBSERVE the Operator Control Station and Data Table Access Module AND RECORD the water tank level readings below:

\begin{tabular}{|c|c|}
\hline $\begin{array}{c}\text { OPERATOR CONTROL STATION } \\
\text { WATER TANK LEVEL } \\
11.7 \text { to } 12.7 \text { jnches Water } \\
\text { Gauge) }\end{array}$ & $\begin{array}{c}\text { DATA TABLE ACCESS MODULE } \\
\text { WATER TANK LEVEL } \\
11.7 \text { to } 12.7 \text { inches Water } \\
\text { Gauge) }\end{array}$ \\
\hline
\end{tabular}

5.3.10 SLOWLY INCREASE the Level Transmitter test Manometer pressure to 12.5-15.5" Water Gauge. 5.3.11 OBSERVE the Operator Control Station and Data Table Access ModuTe AND
RECORD the water tank level readings below:

\begin{tabular}{|c|c|}
\hline $\begin{array}{c}\text { OPERATOR CONTROL STATION } \\
\text { WATER TANK LEVEL } \\
\text { (RANG: } 14.5 \text { to } 16.5 \text { inches) }\end{array}$ & $\begin{array}{c}\text { DATA TABLE ACCESS MODULE } \\
\text { WATER TANK LEVEL } \\
\text { (RANGE } 14.5 \text { to } 16.5 \text { inches) }\end{array}$ \\
\hline & \\
\hline
\end{tabular}

\begin{tabular}{|c|c|c|c|c|}
\hline REFERE & $\begin{array}{l}\text { Document No: } \\
\text { OTP-200-00 }\end{array}$ & $\begin{array}{l}\text { Revplool } \\
\text { A-16 }\end{array}$ & Felenst gats $8 / 23 / 99$. & 25 of 108 \\
\hline
\end{tabular}




\section{Test 5.3 VERIFY DATA TABLE ACCESS MODULE AND OPERATOR CONTROL STATION}

excoption 5.3.12 VERIFY that the water Tank Low Level alarm CLEARS at the Operator $+1$

\subsubsection{REMOVE the test manometer from the SALW-LT-6003* high pressure vent/test port. AND RE.INSTALL vent plugs.}

5.3.14 RESTORE the Water Tank Level Transmittor SALW-LT-6003* by PERFORMING the following: 5.3.14.1 OPEN valve SALW-V-6089*
(WATER TANK ENCL).

5.3.14.2 OPEN valve SALW- $-K-6031 *$. located in the bottom of SALW-PNL-6003* (WATER TANK ENGLY.

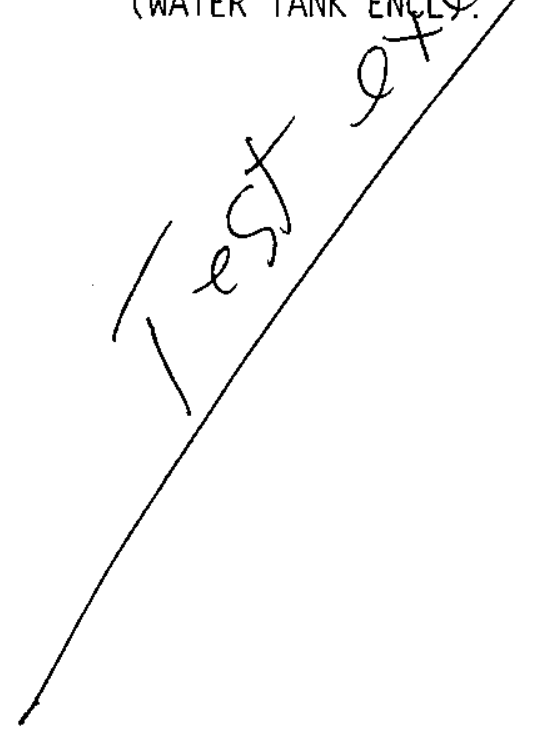

\begin{tabular}{|c|c|c|c|c|}
\hline REFEREN & OTP-200-00 & Aevrliod & 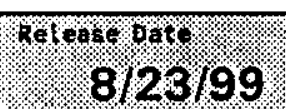 & 26 \\
\hline
\end{tabular}




\subsection{VERIFY DATA TABLE ACCESS MODULE AND OPERATOR CONTROL STATION} ANALOG INPUT SIGNALS (CONT.)

Testexc of im WEIGHT FACTOR TEST

2. 5.3 .15

VERIFY that NO Programmable Logic Controller input signals are FORCEO and that the forcing function is DISABLED.

5.3.16 CONNECT the 0-500" Water Gauge test Manometer pressure source to the HIGH PRESSURE dip tube on the side of the "WFIE Cabinet".

5.3.17 ENSURE SALW-V-6001* is CLOSEQP

5.3 .18

5.3 .19

ENSURE SALW-V-6P06 IS OPEN.

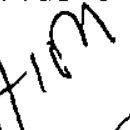

5.3.20 ENSURE adjustment/valves on SALW-FIV-6002*. SALW-FIV-6003*.

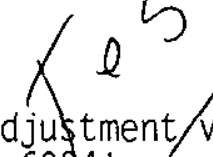

SALW-FIV-6004* are CLOSED.

5.3.21 ENSURE SALW-WFT-6002* EQUALIZING valve located on SALW-V-6036* 3-Valve Mahifold in cabinet SALW-PNL-6002* (WFIE Cabinet) is CLOSED.

5.3.22 ENSURE the LOW side and HIGH side isolation vaives, located on SALW-V-6036* 3-Valve Manifold in cabinet SALW-PNL-6002* (WFIE Cabinet) are OPEN.

\begin{tabular}{|c|c|c|c|c|}
\hline TYPO & 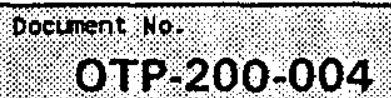 & Reviod & Releass for : 8123199 & 97 of 108 \\
\hline
\end{tabular}


5.3 VERIFY DATA TABLE ACCESS MODULE AND OPERATOR CONTROL STATION

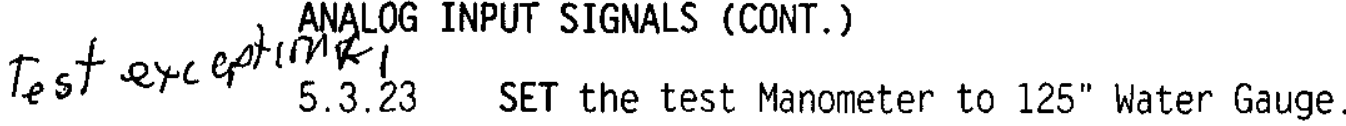

5.3.24 OBSERVE Operator Control Station and Data Table Access Module AND RECORD the Weight Factor on the table below.

\begin{tabular}{|c|c|}
\hline $\begin{array}{c}\text { OPERATOR CONTROL STATION } \\
\text { WEIGHT FACTOR READING } \\
\text { (RANGE 120 to 130 inches) }\end{array}$ & $\begin{array}{c}\text { DATA TABLE ACCESS MODULE } \\
\text { WEIGHT FACTOR READING } \\
\text { (RANGE 120 to 130 inches) }\end{array}$ \\
\hline
\end{tabular}

5.3.25 BLEED off pressure from the manoter.

5.3.26 DISCONNECT the $0-5$ bot test Manometer pressure source.

5.3 .27

5.3 .28

CLOSE SALW-Y-

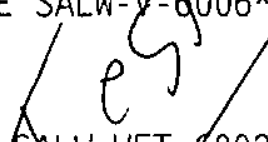

OPEN SALW-WFT-6002* equalizing valve. located on SALW-V-6036* 3-Valve Manifold in gabinet SALW-PNL-6002* (WFIE Cabinet).

5.3.29 CLOSE the LOW side and HIGH side isolation valves, located on SALW-V-6036* 3 -Valve Manifold in cabinet SALW-PNL-6002* (WFIE (abinet).

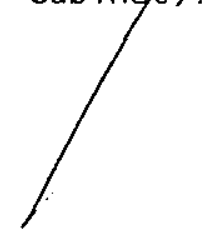

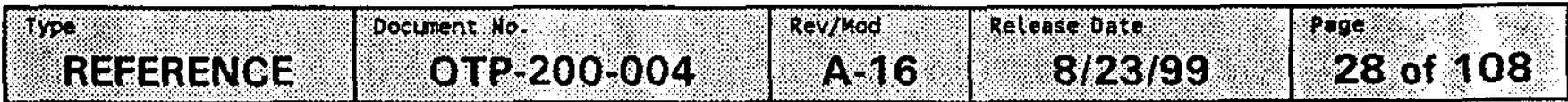




\subsection{VERIFY DATA TABLE ACCESS MODULE AND OPERATOR CONTROL STATION}

Test ANALOG INPUT SIGNALS (CONT.)

EXc cPtion SPECIFIC GRAVITY TEST

NOTE - A mock signal to the specific gravity transmitter is required to keep a low saltwell level alarm from preventing testing of other instrumentation.

5.3.30 CONNECT the 0-50" Water Gauge test Manometer pressure source to the HIGH PRESSURE dip tube.

5.3.31 ENSURE SALW-V-6007* is OPEN.

5.3.32 ENSURE SALW-V-6005* is OPENC

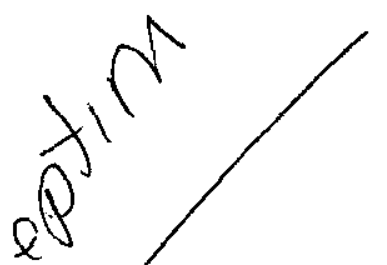<smiles>CC1(C)CCCCC1(C)C</smiles>

5.3.33 ENSURE the LOW side and the HIGH side isolation valves. located on SALW-V-6035* in cabjinet SALW-PNL-6002* (WFIE Cabinet) are OPEN.

5.3.34 CLOSE the Sxec(1)ic Grovity Transmitter equalizing valve located on SALW-V-6038* in cabiget SALW-PNL-6002* (WFIE Cabinet).

5.3.35 SET the test Manometer to 5 " Water Gauge $\left( \pm .3^{\prime \prime}\right)$.

5.3.36 OBSERVE Operator Control Station and Data Table Access Module AND RECORD the/Specific Gravity reading on the table below.

\begin{tabular}{|l|l|}
\hline $\begin{array}{l}\text { OPERATOR CONTROL STATION } \\
\text { SPECIFIC GRAVITY READING } \\
\text { (RANGE 4.6 to 5.4 inches) }\end{array}$ & $\begin{array}{l}\text { DATA TABLE ACCESS MODULE } \\
\text { SPECIFIC GRAVITY READING } \\
\text { (RANGE 4.65 to 5.35 inches) }\end{array}$ \\
\hline
\end{tabular}

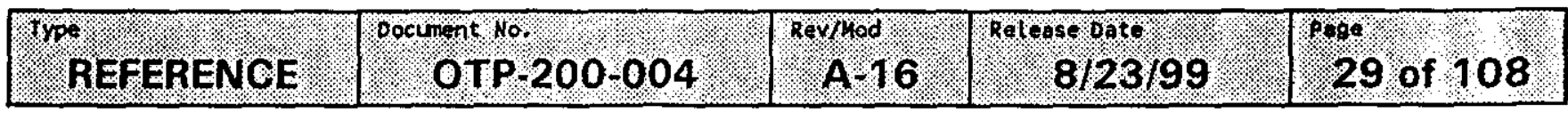




\subsection{VERIFY DATA TABLE ACCESS MODULE AND OPERATOR CONTROL STATION} ANALOG INPUT SIGNALS (CONT.)

Test

FLOW METER TEST

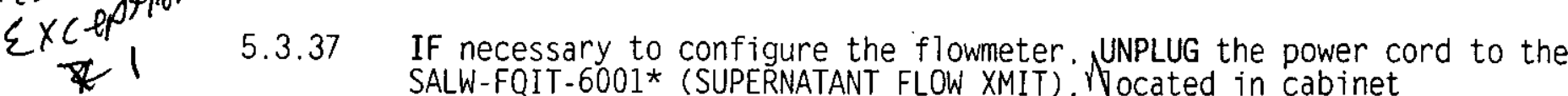

SALW-FQIT-6001* (SUPERNATANT FLOW XMIT). pocated in cabinet

SALW-PNL-6002* (WFIE Cabinet).

5.3.38 IF a Brooks flowmeter is used. CONAIGURE SACW-FQIT-6001*, located in cabinet SALW-PNL-6002* (WFIE CabDet), to receive signals from a hand
held calibrator.

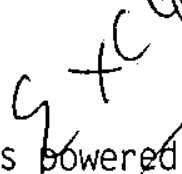

5.3.39 ENSURE SALW-FQIT-6001* is fowered and configured for simulated flow

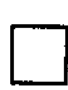

\section{signals.}

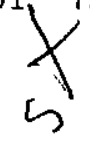

5.3 .40

SIMULATE a flow/sighal of $2.0 \mathrm{gpm}$ ( $50 \%$ span) with the hand held calibrator, or from flowmeter face plate.

5.3.41 VERIFY the SALW-FQIT-6001* transmitter is operating properly by RECORDING the following:

\begin{tabular}{|c|c|c|}
\hline $\begin{array}{c}\text { OPERATOR CONTROL STATION } \\
\text { SUPERNATANT FLOW } \\
\text { (RANGE: } 1.8 \text { to } 2.2 \mathrm{GPM})\end{array}$ & $\begin{array}{c}\text { DATA TABLE ACCESS MODULE } \\
\text { SUPERNATANT FLOW } \\
\text { (RANGE: } 1.8 \text { TO 2.2 GPM) }\end{array}$ & $\begin{array}{c}\text { SUPERNATANT FLOW XMIT } \\
\text { SUPERNATANT FLOW } \\
\text { (RANGE: } 1.8 \text { TO 2.2 GPM) }\end{array}$ \\
\hline & & \\
\hline
\end{tabular}

5.3.42 RESTORE the SALW-FQIT-6001* (SUPERNATANT FLOW TRANSMITTER) to its original configuration.

\begin{tabular}{|c|c|c|c|c|}
\hline REFERENCE. & Docinent & Aerimodis 16 & fetease pato & 30 of 108 \\
\hline
\end{tabular}




\subsection{VERIFY DATA TABLE ACCESS MODULE AND OPERATOR CONTROL STATION ANALOG INPUT SIGNALS (CONT.)}

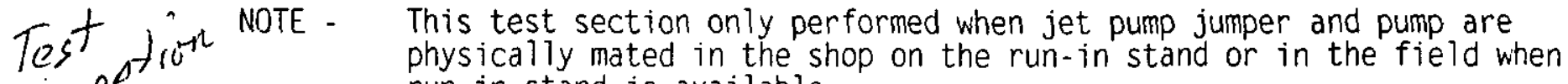
Excef run in-stand is available.

\section{DISCHARGE PRESSURE TEST}

5.3.43 ENSURE Pump recirculation apparatus is filled with water AND configured to circulate water salgh the saltwell Jet Pump jumper.

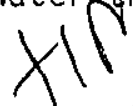

5.3.44 PLACE JR-1 valve in the PRQdess position.

5.3.45 At the discretion of the/fest Director. INSTALL temporary inter lock jumpers. OR INIJIATE la software force on pump permissive interlocks for equipment not installed or out of service.

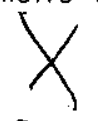

5.3.46 USING the Data Table Access Module. START the Jet Pump.

5.3.47 RECORD the following pressures on the table below:

\begin{tabular}{||c|c|c|c|c||}
\hline $\begin{array}{c}\text { SALW-PI-6012* } \\
\text { JET PUMP } \\
\text { SUCTION PRESSURE }\end{array}$ & $\begin{array}{c}\text { TEST GAUGE } \\
\text { PJ-1 }\end{array}$ & $\begin{array}{c}\text { DTAM } \\
\text { DISCHARGE } \\
\text { PRESSURE }\end{array}$ & $\begin{array}{c}\text { SALW-PI-6011* } \\
\text { JET PUMP } \\
\text { DISCHARGE PRESSURE }\end{array}$ & $\begin{array}{c}\text { TEST GAUGE } \\
\text { PI-2 }\end{array}$ \\
\hline & & & & \\
\hline
\end{tabular}

5.3.48 Using the Data Table Access Module. STOP the Jet Pump.

"


5.3 VERIFY DATA TABLE ACCESS MODULE AND OPERATOR CONTROL STATION ANALOG INPUT SIGNALS (CONT.)

testexcept PIT FLAMMABLE GAS MONITOR TEST

X 1 5.3.49 CONNECT a current source to model 4.0 FGM TB2 terminals $15(+)$ and 16(-) or model 4.46 FGM wires 501(+) and 502(-) at PLC-A0, located in the pit flammable gas monitor electrical cabinet or in the PICS Instrument Enclosure. PLC MODULE 1. IN $\mathrm{O}(+)$ and IN $\mathrm{O}(-)$.

5.3.50 SET current source to $4 \mathrm{~mA}( \pm .25 \mathrm{~mA})$.

5.3.51 RECORD the Data Table Access Mddule Flammable Gas DISPLAY on the "Pit FGM Input/Output Table" befow.

5.3.52 SET current source $6 \mathrm{f} 1 \mathrm{~mA} / \pm .25 \mathrm{~mA})$.

5.3.53 RECORD the pata Table Access Module Flammable Gas display on the "Pit FGM Input/outpat Jable' below.

5.3.54 SET current sburge to $20 \mathrm{~mA}( \pm .25 \mathrm{~mA})$.

5.3.55 RECORD the Data Table Access Module Flammable Gas display on the "Pit FGM Input/Oytput Table" below.

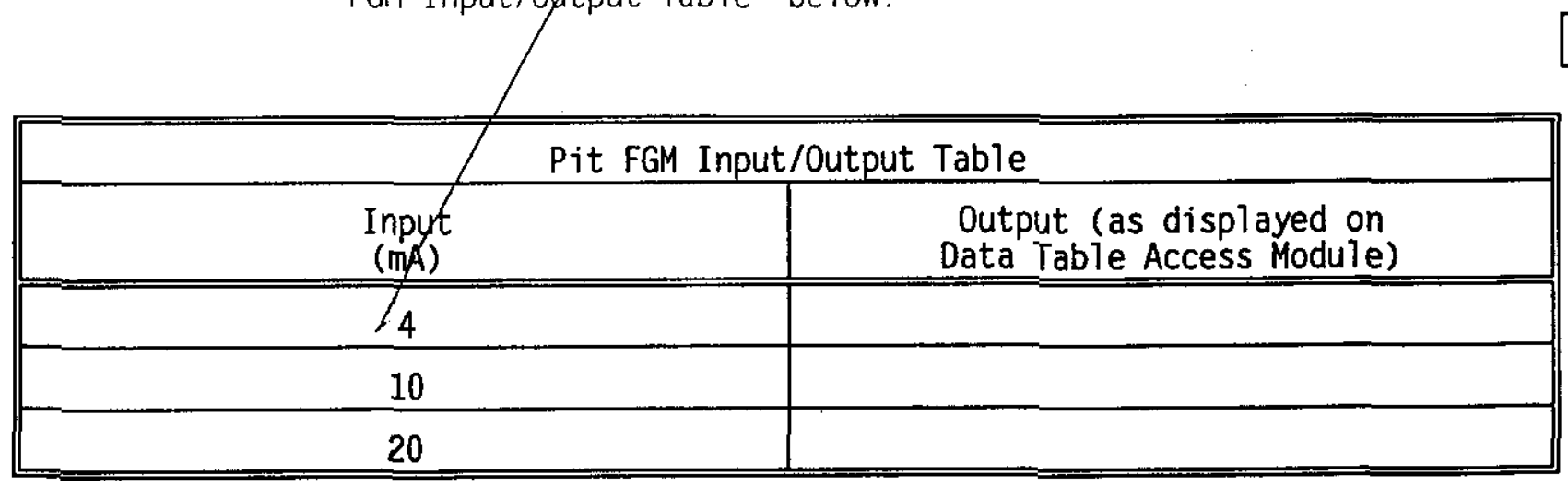

5.3.56 DISCONNECT the current source. AND if necessary

RESTORE 10op intercepted in step 5.3.49 (located in pit FGM).

\begin{tabular}{|c|c|c|c|c|}
\hline "YPR & pocuntent to & : $4.16 \%$ & Rers oate 8123199 & 32 of 108 \\
\hline
\end{tabular}


5.3 YERIFY DATA TABLE ACCESS MODULE AND OPERATOR CONTROL STATION Tes texceptoANALOG INPUT SIGNALS (CONT.)

* 1 NOTE - This test section only performed if a dome space FGM is installed.

DOME SPACE FLAMMABLE GAS MONITOR TEST

5.3.57 CONNECT a current source to model 4.0 FGM TB2 termina1s 15(+) and $16(-)$ or model 4.46 FGM wires $501(+)$ and $502(-)$ at PLC-A0. located in the dome space flammable gas monitor electrical cabinet or in the PICS Instrument Enclosure. PLC MOOULE 6 . IN $O(+)$ and IN $0(-)$.

5.3.58 SET current source to $4 \mathrm{~mA}$ \& $f$ fo $\mathrm{mA}$.

5.3.59 RECORD the Data Table Acces Module Flammable Gas DISPLAY on the "Dome Space FGM Input/0utput Jable" below.

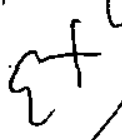

5.3.60 SET current soyrce to $10 \mathrm{~mA}( \pm .25 \mathrm{~mA})$.

5.3.61 RECORD the Daca Table Adcess Module Flammable Gas display on tre "Dome Space EGM Input/Output Table" below.

5.3.62 SET current/source to $20 \mathrm{~mA}( \pm .25 \mathrm{~mA})$.

5.3.63 RECORD the Data Table Access Module Flammable Gas display on tr:e "Dome Sface FGM Input/Output Table" below.

\begin{tabular}{||c|c|}
\hline & $\begin{array}{r}\text { Dome Space FGM Input/Output Table } \\
\hline\end{array}$ \\
\hline $\begin{array}{c}\text { Input } \\
(\mathrm{mA})\end{array}$ & $\begin{array}{c}\text { Output (as displayed on } \\
\text { Data Table Access Module) }\end{array}$ \\
\hline 4 & \\
\hline 10 & \\
\hline 20 & \\
\hline
\end{tabular}

5.3.64 DISCONNECT the current source, AND if necessary

RESTORE loop intercepted in step 5.3.57 (located in dome space FGM).

\begin{tabular}{|c|c|c|c|c|}
\hline PEFERENCE & Dooument lo. & $\begin{array}{l}\text { Reviliod } 16 \\
\text { A } 16\end{array}$ & Relenst Dato & 33 of 108 \\
\hline
\end{tabular}




\subsection{VERIFY DATA TABLE ACCESS MODULE AND OPERATOR CONTROL STATION}

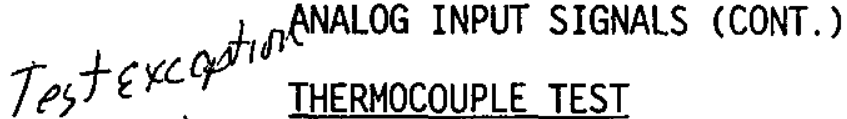
\# 1

\section{THERMOCOUPLE TEST}

5.3.65 WARM thermocouple SALW-TE-6004*, located in the Instrument Enclosure.

5.3.66 VERIFY Data Table Access Module and Operator Control Station display a changed temperature (Operator Control Station and Data Table Access Module should match $\pm 2^{\circ} \mathrm{F}$ ).

\section{3 .67}

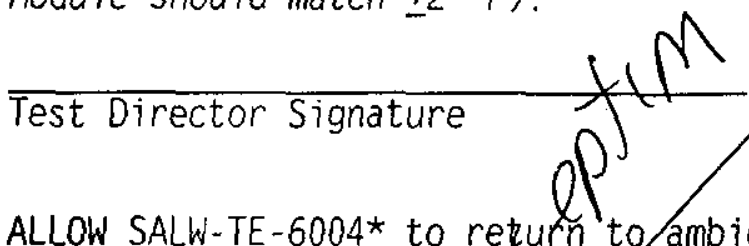

Date

5.3 .68

5.3 .69

ALLOW SALW-TE-6004* to repurn to ambient temperature.

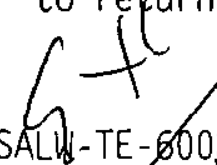

WARM thermocouple SALW-TE-6003*, 10cated in SALW-PNL-6001* INSTRUMENT AIR ENCLOSURE.

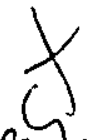

VERIFY Data Ta(le Adcess Module and Operator Control Station DISPLAY a changed emperature. (Operator Control Station and Data Table Access Module should match $\pm 2^{\circ} \mathrm{F}$ ).

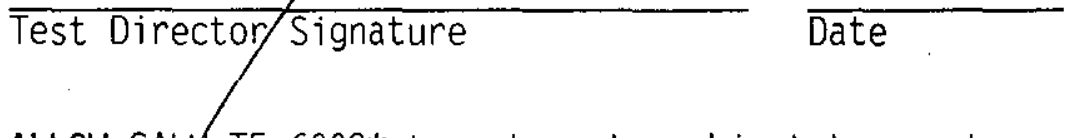

5.3.70 ALLOW SAYK-TE-6003* to return to ambient temperature.

5.3.71 WARM thermocouple SALW-TE-6001*. located on the Jet Pump.

5.3.72 VERIFY Data Table Access Module and Operator Control Station DISPLAY a changed temperature. (Operator Control Station and Data Table Access Module should match $\pm 2^{\circ} \mathrm{F}$ ).

$\overline{\text { Test Director Signature }} \overline{\text { Date }}$

5.3.73 ALLOW SALW-TE-6001* to return to ambient temperature.

\begin{tabular}{|c|c|c|c|c|}
\hline REFERENCE & $\begin{array}{l}\text { Dociment io. } \\
\text { OTP-200-004 }\end{array}$ & $\begin{array}{l}\text { Revinod } \\
\text { A-16 }\end{array}$ & $\begin{array}{r}\text { Retenti dater } \\
8 / 23 / 99\end{array}$ & 34 of 108 \\
\hline
\end{tabular}




\subsection{VERIFY DATA TABLE ACCESS MODULE AND OPERATOR CONTROL STATION}

lest $8 \times c+p^{4}+100$ 世的
5.3 .74

5.3 .75

5.3 .76

5.3 .77

5.3 .78

5.3 .79
WARM thermocouple SALW-TE-6002* (Jet Pump over temperature thermocouple located on the saltwell Jet Pump jumper).
VERIFY Data Table Access Module and Operator Control Station DISPLAY a changed temperature (Operator Control Státion and Data Table Access Module should match $\pm 2^{\circ} \mathrm{F}$ ).

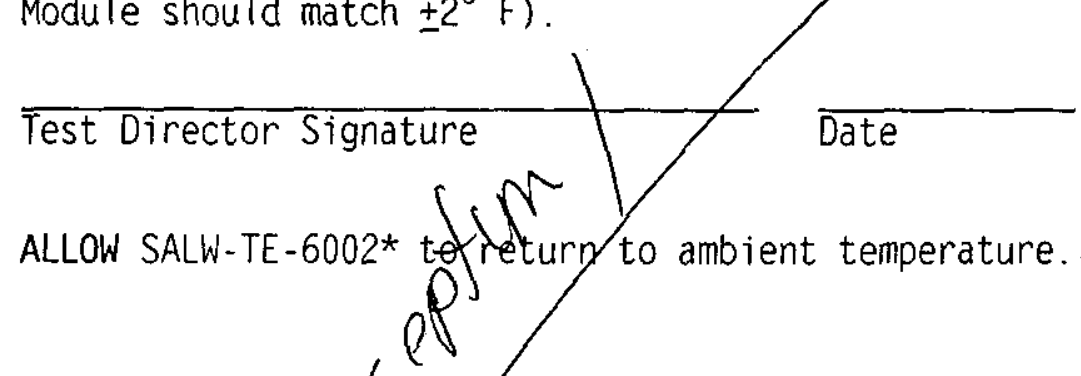

REMOVE any jumpef for forces NOT required for the next test section.

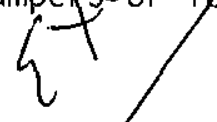

Test Director VERIfy that section 5.3 is complete by SIGNING below.

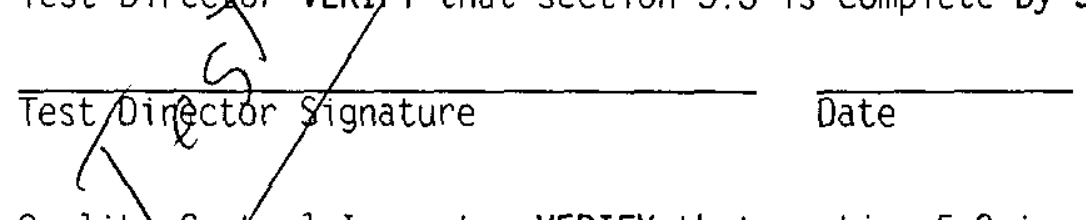

Quality Control Inspector VERIFY that section 5.3 is complete by signing below.

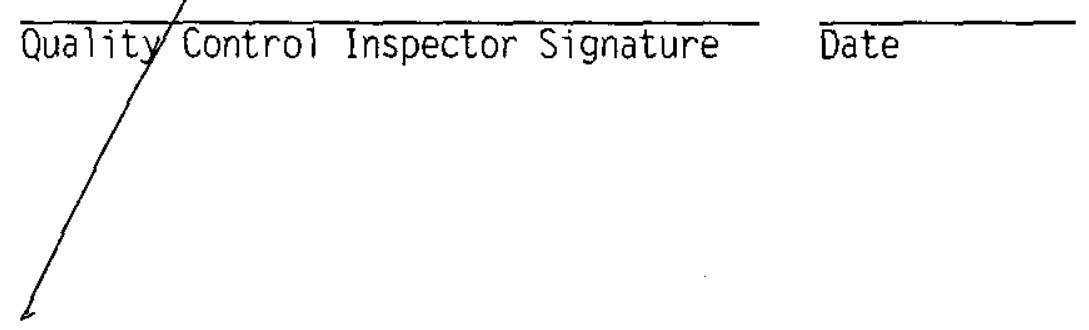

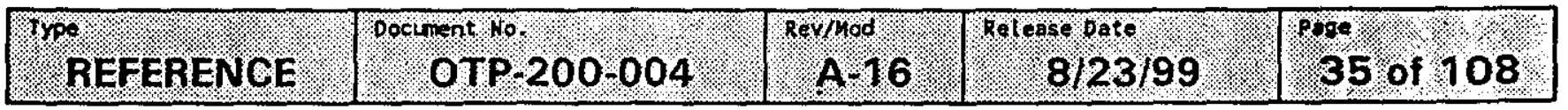




\subsection{VERIFY DATA TABLE ACCESS MODULE AND OPERATOR CONTROL STATION} Testexecp $t$ PDISCRETE SIGNAL INPUTS

VALVE POSITION TEST

H 5.4.1 ENSURE the JR-1 valve is in the PROCESS position.

5.4.2 VERIFY the JR-1 valve indicates "norm" at the Data Table Access Module AND "PROCESS" position at the pperator Control Station.

5.4.3 PLACE the JR-1 valve in the LUSP position.

5.4.4 VERIFY the JR-1 valve ind idfes "AON-PROCESS" at the Data Table Access Module AND "FLUSH" position at the Operator Control Station.

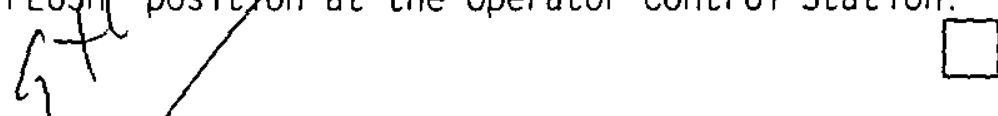

5.4.5 PLACE the JR-1 yajve in the PRIME position.

5.4.6 VERIFY the JR Q Dalve/indicates "NON-PROCESS" at the Data Table Access Module AND "ORIME" position at the Operator Control Station.

FLUSH LINE PRESSURE TEST

5.4.7 PLACE the JR-1 valve in the PROCESS position.

5.4.8 VERIFY a yater supply is connected to the jumper flush hose.

5.4.9 ENSURE Pump recirculation apparatus is filled with water AND configured to circulate water through the saltwell Jet Pump jumper 
5.4 VERIFY DATA TABLE ACCESS MODULE AND OPERATOR CONTROL STATION DISCRETE SIGNAL INPUTS (Cont.)

Test sxception

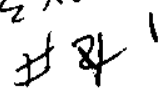

5.4 .10

At the discretion of the Test Director. ENSURE temporary interlock jumpers. OR software forces have been installed on pump permissive interlocks for equipment not installed or out of service.

5.4.11 USING the Data Table Access Module. START the Jet Pump.

5.4.12 VERIFY the Jet Pump OPERATION at the Operator Control Station.

5.4.13 ACTUATE pressure swith PSH 6002* transducer SALW PT $6014^{*}$ (old

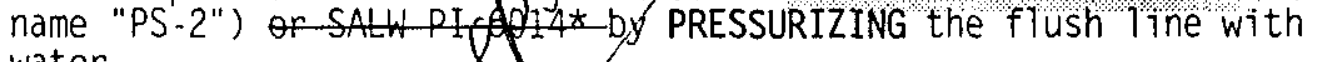
water.
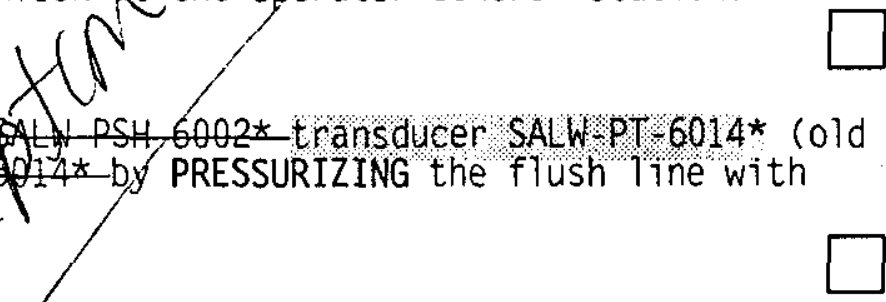

5.4.14 VERIFY the Jet Plinp IMMEDSATELY shuts down at the Data Table Access Module and Operator Control Station.

5.4.15 VERIFY flush Tine high pressure alarm *3. "FLUSH PRESSURE HIGH" annuncjates at the Data Table Access Module and Operator Control

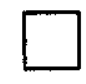

5.4.16 SHUT OFF the water supply to the flush line. 5.4.17 CYCLE the JR-1 valve to CLEAR the flush line high pressure alarm.

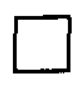

\section{". REFERENOE}

HNF-5820, Rev. 0 pochent $\mathrm{No}$.

OTP-200-004
Revirod

A-16
Retease oats

$8 / 23 / 99$ 
5.4 VERIFY DATA TABLE ACCESS MODULE AND OPERATOR CONTROL STATION Test Exe op iOODISCRETE SIGNAL INPUTS (Cont.) It 1 LOW PRESSURE INTERLOCK

5.4.18 PLACE the JR-1 valve in the PROCESS position.

5.4.19 ENSURE ALL alarms have been acknowledged at Data Table Access Module and Operator Control Station.

5.4.20 ENSURE the pump is NOT prfied.

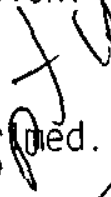

5.4.21 ENSURE the Diaphragnifperated valve is CLOSED.

5.4.22 USING the Data Table Access Module. START the Jet Pump.

5.4.23 VERIFY the Yet p/mp shuts down in approximately thirty (30) seconds ( \pm 5 setonds)

5.4.24 VERIFY transfer line low pressure alarm \#1 "XFR Pressure LOW" annunciates at the Data Table Access Module and Operator Control Station.

5.4.25 ACKNOWLEDGE alarms at Data Table Access Module and Operator Control Station.
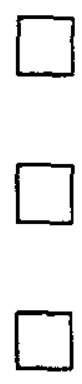
5.4 VERIFY DATA TABLE ACCESS MODULE AND OPERATOR CONTROL STATION DISCRETE SIGNAL INPUTS (Cont.)

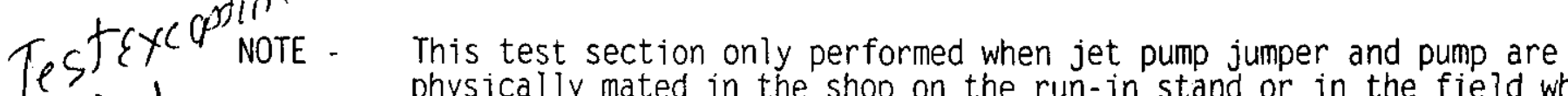
$\#+1$ physically mated in the shop on the run-in stand or in the field when run in-stand is available.

HIGH PRESSURE INTERLOCK

5.4.26 PLACE the JR-1 valve in the fPRDME position.

5.4.27 If a water ram will be usgd. Uusing skill of the craft CONNECT a water ram to the jet pump jumpeO AND SLOWLY PRESSURIZE the pump and jumper to 140 psi using water.

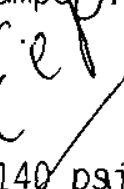
5.4.28 IF pump will deviliod 140 pqi. START jet pump with JR-2. BYPASS valve
and DOV closed.

5.4.29 VERIFY that the "XFR Pressure HIGH" alarms at Data Table Access Module (A hârm $* 2)$ and Operator Control Station when pressure reaches 140 psx $(410$ osi $)$.

5.4.30 ACKNOWLEDGE alarms at Data Table Access Module and Operator Control Station.

RECIRCULATION FLOWMETER TEST

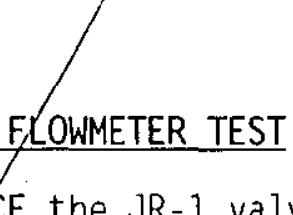

5.4.31 PLACE the JR-1 valve in the PROCESS position.

5.4.32 ENSURE Pump recirculation apparatus is filled with water AND configured to circulate water through the saltwell Jet Pump jumper.

5.4.33 CONFIGURE SALW-FI-6001* (PMP RECIRC FLOW) to receive signals from a control and display unit.

\begin{tabular}{|c|c|c|c|c|}
\hline & Pocument No: & Revplod & $\begin{array}{l}\text { Retche pato } \\
8123199\end{array}$ & pqop? \\
\hline
\end{tabular}




\subsection{VERIFY DATA TABLE ACCESS MODULE AND OPERATOR CONTROL STATION DISCRETE SIGNAL INPUTS (Cont.)}

Test ixcestion. $\#$ \& 1
5.4 .34

CONFIGURE the control and display unit to simulate flow signals using the Installation. Diagnostics. Test/Control Mode. AN CAL function.

5.4.35 SIMULATE a flow signal of $0.6 \mathrm{gpm}$ with the control and display unit.

5.4.36 At the discretion of the TeNt Director. ENSURE temporary interlock jumpers OR software forges have been installed on pump permissive interlocks for equipment not installed or out of service.

5.4.37 USING the Data Table Access Module. START the Jet Pump.

5.4.38 VERIFY the Jet PUMP OPERATION at the Operator Control Station.

5.4.39 SIMULATE a fldinsigpal of $\partial_{4} \mathrm{gpm}$ with the control and display unit.

5.4.40 VERIFY the let pump shuts down (after $30 \pm 5 \mathrm{sec}$.) at the Data Table Access Module and Operator Control Station.

5.4.41 VERIFY Jet pump recirculation line low flow alarm *21. "RECIRCULATION FAILURE" annunciates at the Data Table Access Module and Operator Control station.

5.4.42 RESTORE SALW-FI-6001* to its original configuration.

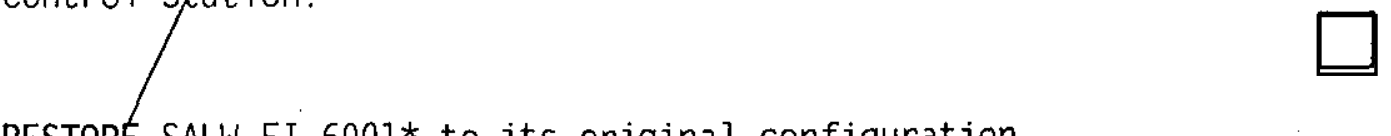

5.4.43 CYCLE the JR-1 valve to CLEAR the Jet Pump recirculation line low flow alarm.

\begin{tabular}{|c|c|c|c|c|}
\hline YPr REFERENCE. & 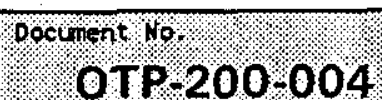 & Revphod: & fot 8123199 & 40 of 108 \\
\hline
\end{tabular}




\subsection{VERIFY DATA TABLE ACCESS MODULE AND OPERATOR CONTROL STATION DISCRETE SIGNAL INPUTS (Cont.)}

seetest

ixception

\section{RECIRCULATION FLUSH LINE PRESSURE TEST}

5.4.44 PLACE the JR-1 valve in the PROCESS position.

$\pm \mathbb{2}$

5.4.45 VERIFY a water supply is connected to the regirculation flush line.

5.4.46 ENSURE Pump recirculation apparatus is/filled with water AND configured to circulate wat through the saltwell Jet Pump jumper.

5.4.47 At the discretion of the JiJest grector. ENSURE temporary inter lock jumpers OR software forkes haye been installed on pump permissive inter locks for equipment not/installed or out of service.

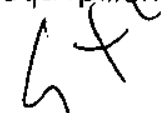

5.4.48 USING the Data Tabte Accless Module. START the Jet Pump.

5.4.49 VERIFY the Jet Pump OPERATIQN at the Operator control Station.

5.4.50 ACTUATE pressure indicator transducer SALW-PT-6013* (RECIRC FLUSH PRESS) by PRESSORIZING the recirculation flush line with water.

5.4.51 VERIFY the pet Pump IMMEDIATELY shuts down at the Data Table Access Module and/Operator Control Station.

5.4.52 VERIFY fecirculation flush line high pressure alarm *39. "RECIRC FLUSH PRSS HI" annunciates at the Data Table Access Module and Operator Control Station.

5.4.53 SHUT OFF the water supply to the recirculation flush line.

5.4.54 CYCLE the JR-1 valve to CLEAR the recirculation flush line high pressure alarm.

4. REFERENCE : :


5.4 VERIFY DATA TABLE ACCESS MODULE AND OPERATOR CONTROL STATION DISCRETE SIGNAL INPUTS (Cont.)

Test Exce

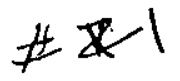

5.4.56 Test Director VERIFY that section 5.4 is complete by SIGNING below. Test Director Signature

5.4.57 Quality Control Inspedto VerIEy that section 5.4 is complete by signing below.

$$
\text { Quality control Inspector signature }
$$
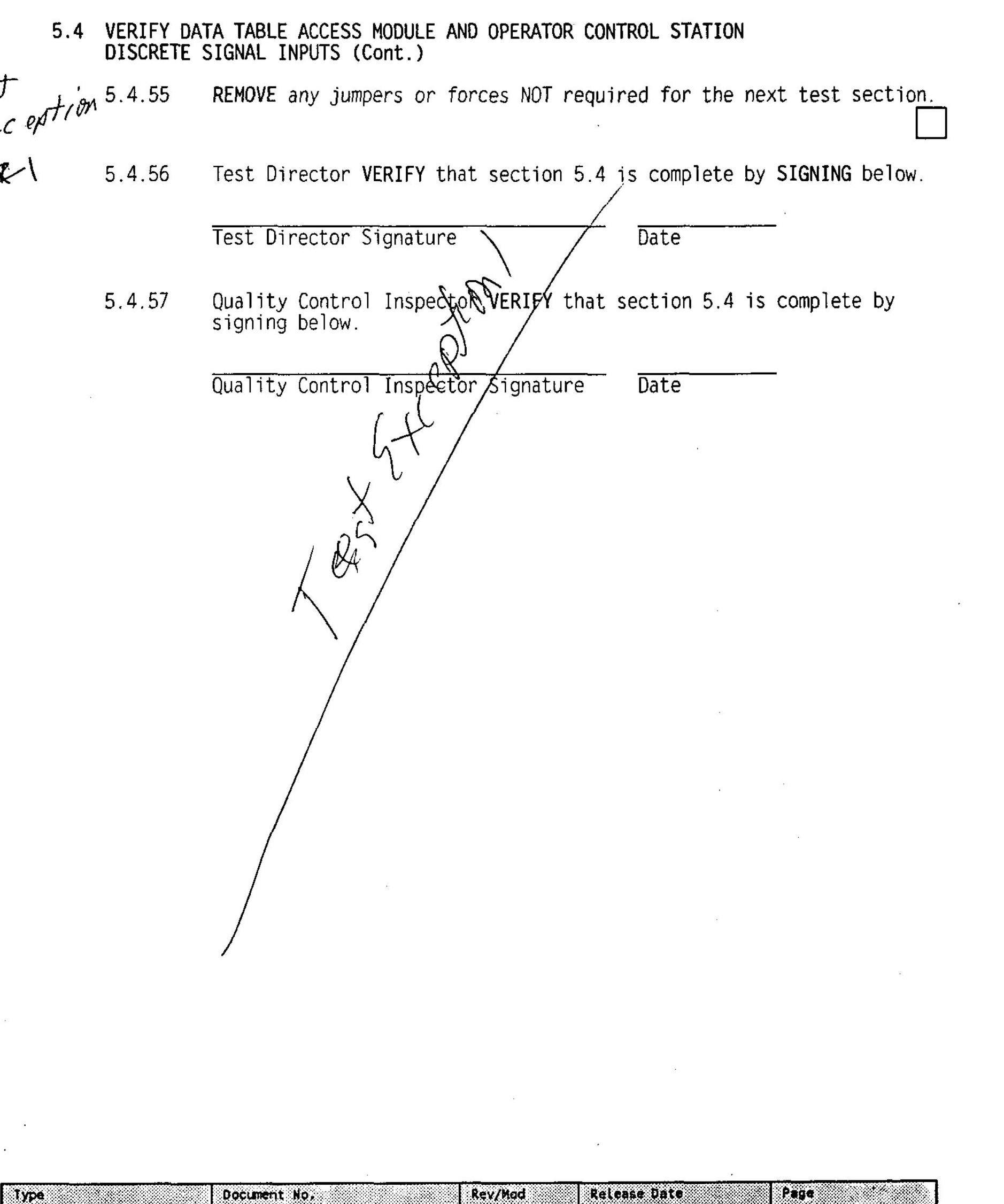


\subsection{VERIFY DATA TABLE ACCESS MODULE AND OPERATOR CONTROL STATION MONITOR/ALARM FUNCTIONS}

Test Excepticts.5.1 世政1.

At the discretion of the Test Director. ENSUBE temporary interlock jumpers, OR software forces are in place foy uninstalled equipment.

5.5.2 SET the test manometer on the specific/gravity transmitter to 13" Water Gauge.

5.5 .3

ENSURE the following valvers
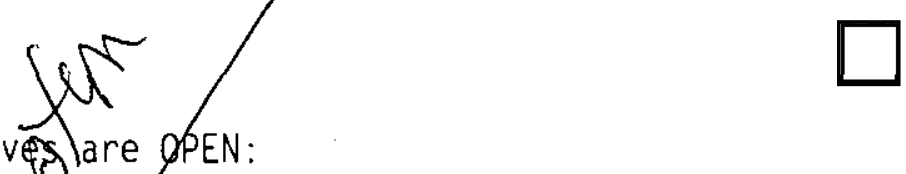

5.5.4 ENSURE Puhp recidculation apparatus is filled with water AND

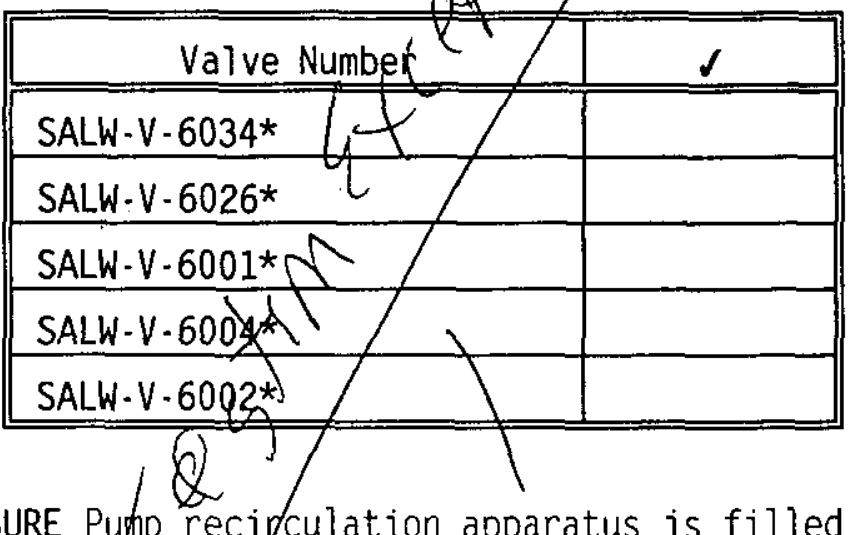
configured to cjrculate water through the saltwell Jet Pump.

5.5.5 START the Jef Pump using the Data Table Access Module. AND PLACE the system in automatic.

5.5.6 VERIFY the DIAPHRAGM OPERATED VALVE mOVES OPEN.

5.5.7 OBSERVE the Operator Control Station and Data Table Access Module ANO RECORD the specific gravity readings below:

\begin{tabular}{|l|l|}
\hline $\begin{array}{c}\text { OPERATOR CONTROL STATION } \\
\text { SPECIFIC GRAVITY READING } \\
\text { (RANGE 12.6 to } 13.4 \text { inches) }\end{array}$ & $\begin{array}{c}\text { DATA TABLE ACCESS MODULE } \\
\text { SPECIFIC GRAVITY READING } \\
\text { (RANGE } 12.65 \text { to } 13.35 \text { inches) }\end{array}$ \\
\hline
\end{tabular}

\section{REFERENCE : |}




\subsection{VERIFY DATA TABLE ACCESS MODULE AND OPERATOR CONTROL STATION MONITOR/ALARM FUNCTIONS (CONT.)}

Test excost $1021^{5.5 .8}$

VERY SLOWLY DECREASE the test manometer pressure until the Data Table Access Module "SGT LOW" alarm (alarm *13) annunciates.

\#账 1

NOTE - SALW-PI-6005* pressure is to be recorded in the table below when DOV position indicates fully closed.

5.5.9 VERIFY AND ACKNOWLEDGE the Specific Gadavity Low Alarm (Saltwell LOw! Level) at the Data Table Access Module and Operator Control Station.

5.5.10 RECORD the following:

\begin{tabular}{|c|c|}
\hline PARAMETER & READING \\
\hline $\begin{array}{l}\text { OPERATOR CONTROL STATION } \\
\text { SPECIFIC GRAVITY (RANGE } 3 \text { to } \\
\end{array}$ & \\
\hline $\begin{array}{l}\text { DATA TABLE ACCESS MODULE } \\
\text { SPECIFIC GRAVITY (RANGE } 3\end{array}$ & \\
\hline $\begin{array}{l}\text { SPECIFIC GRAVITY MANOMETER RE } \\
\text { (RANGE } 3 \text { to } 4 \text { inches Water Gau }\end{array}$ & \\
\hline $\begin{array}{l}\text { DOV POSITION (\% OPEN) } \\
\text { [RANGE - FULLY CLOSED] }\end{array}$ & \\
\hline $\begin{array}{l}\text { SALW-PI-6005* PRESSURE } \\
\text { (RANGE } 2 \text { to } 4 \text { psig) }\end{array}$ & \\
\hline
\end{tabular}

5.5.11 VERY SLOWLY/INCREASE the test manometer pressure to 10 inches viater Gauge.

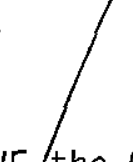

5.5.12 OBSERVE/the Operator Control Station and Data Table Access Module AND RECORD the specific gravity readings below:

\begin{tabular}{|l|c|}
\hline $\begin{array}{l}\text { OPERATOR CONTRCL STATION } \\
\text { SPECIFIC GRAVITY READING } \\
\text { (RANGE 9 to 11 inches) }\end{array}$ & $\begin{array}{c}\text { DATA TABLE ACCESS MODULE } \\
\text { SPECIFIC GRAVITY READING } \\
\text { (RANGE 9 to 11 inches) }\end{array}$ \\
\hline
\end{tabular}

\begin{tabular}{|c|c|c|c|c|}
\hline REFERENCE & Oociment $\mathrm{ko}$ OTP-200-004 & Revimod & \begin{tabular}{|c|} 
fet case sas \\
$8 / 23 / 99$
\end{tabular} & Page 44 of 108 \\
\hline
\end{tabular}


5.5 VERIFY DATA TABLE ACCESS MODULE AND OPERATOR CONTROL STATION Testexcepfiol MONITOR/ALARM FUNCTIONS (CONT.)

$\begin{array}{lll}\text { \# } & 5.5 .13 & \text { VERIFY that the Specific Gravity Low Alarm CLEARS at } \\ \text { Control. Station and at the Data Table Access Module. }\end{array}$

5.5.14 VERIFY the Diaphragm Operated Valve mores OPEN.

5.5.15 REMOVE any jumpers or forces NOT/required for the next test section.

5.5.16 SHUT OFF the jet pumgfesing the Data Table Access Module.

5.5.17 Test Director VERIKY that section 5.5 is complete by SIGNING below.

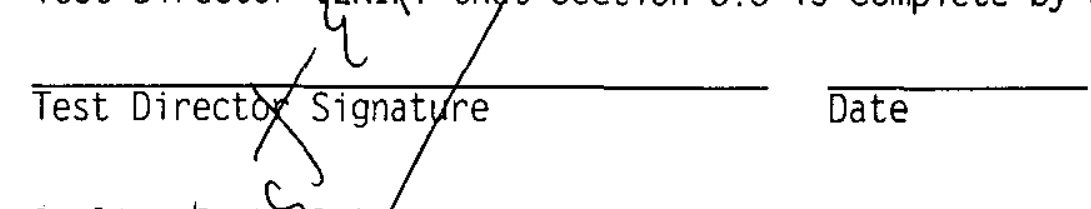

5.5.18 Quality fontral Inspector VERIFY that section 5.5 is complete by signing/betow.

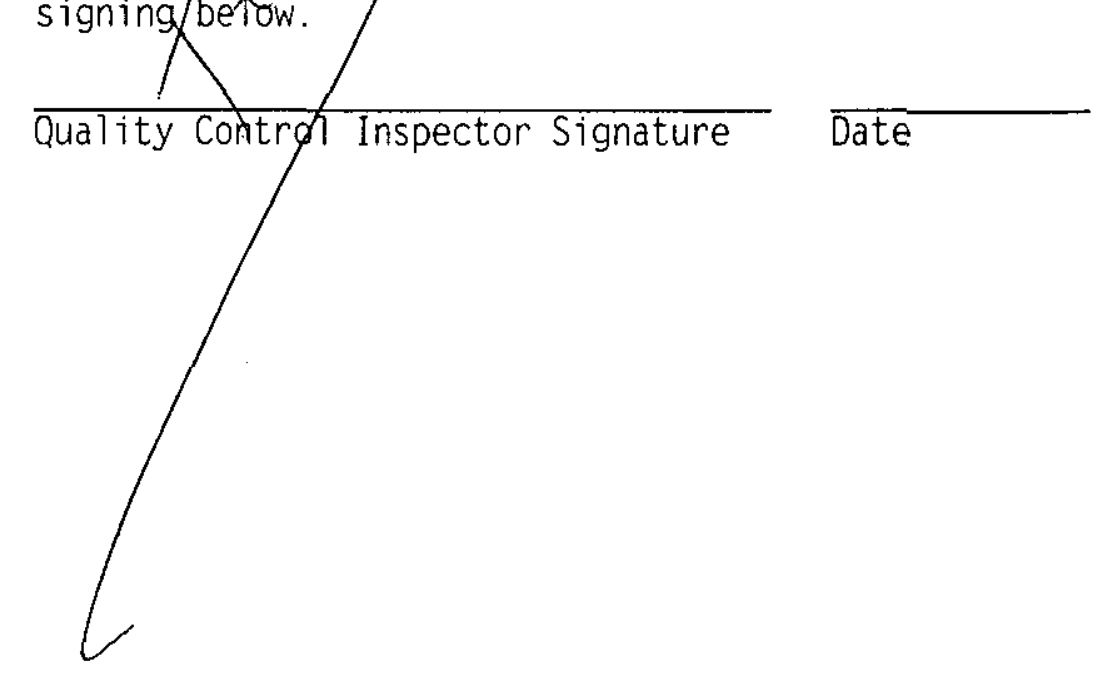




\subsection{REMOTE SETPOINT CHANGE USING THE OPERATOR CONTROL STATION}

seetest

5.6.1 PLACE the saltwell jumper JR-1 valve in the PROCESS position.

axception 进
5.6 .2

5.6 .3

5.6 .4

5.6 .5

5.6 .6

5.6 .7

5.6 .8

ENSURE pump recirculation apparatus is $f$ illed with water. AND configured to circulate water through the saltwell Jet Pump.

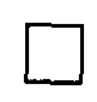




\subsection{DATA TABLE ACCESS MODULE AND OPERATOR CONTROL STATION} DIAPHRAGM OPERATED VALVE AUTOMATIC/MANUAL OPERATION

LOTE - This system is a Proportional Integral Derivative controller for test except(n) controlling the liquid level in the saltwell screen. The Specific 地 1 Gravity Transmitter reads unadjusted liquid level once the middle diptube leg is uncovered by declining liquid levels.

The system uses the signal fram the Specjfic Gravity Transmitter as the Process Variable. The controller conpares the process variable to the setpoint and adjusts the Draphragm Operated Valve position accordingly (manipulated variable).

The purpose of this test fiction is to verify that the Diaphragm Operated Valve trend is Lud achieving the setpoint while different process variables are sinflated.

DATA TABLE ACCESS MODULE (AUTOMAIIC)

5.7.1 ENSURE the Saltwell P(Imp and Jumper Assembly. AND the Pumping and Instrumentation confrol Skfid are configured for AUTOMATIC Diaphragm operated Valve lexel control by PERFORMING the following:

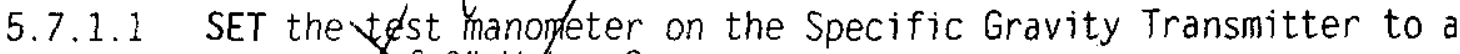
pressurelof 0" Water Gauge.

5.7.1.2 ENSYRE the following valves are OPEN:

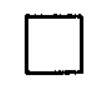

\begin{tabular}{|c|c|}
\hline I valve Number & $\checkmark$ \\
\hline SALW-V-603A* & \\
\hline SALW-V-6026* & \\
\hline SALW-V- $6001 *$ & \\
\hline SALW-V $-6004^{*}$ & \\
\hline SALW N-6002* & \\
\hline
\end{tabular}

5.7.1.3 PLACE the saltwell jumper JR-1 valve in the PROCESS position.

5.7.1.4 At the discretion of the Test Director. ENSURE temporary finterlock jumpers. OR software forces have been installed on pump permissive interlocks for equipment not installed or out of service.

\begin{tabular}{|c|c|c|c|c|}
\hline " REFERENCE. & bocument No OTP-200-004 & ReY/Mod 1.9 & Rifis $8123 / 99$ & Pege 47 of 108 \\
\hline
\end{tabular}




\subsection{DATA TABLE ACCESS MODULE AND OPERATOR CONTROL STATION DIAPHRAGM OPERATED VALVE AUTOMATIC/MANUAL. OPERATION (Cont.)}

Test Except/M5.7.1.5 ENSURE that only alarms "JET PUMP SHUTDOWN" (Alarm 12) and "SGT \#1 LOW" (Alarm 13) on the Data Table Access Module are displayed.

5.7.1.6 ENSURE pump recirculation apparatus is/filled with water AND CONFIGURED to circulate water through the saltwell Jet Pump.

5.7.1.7 START the Jet Pump us ing the Data Table Access Module.

5.7.1.8 SET DIAPHRAGM OPERATEDVVALIE Specific Gravity Controller to AUTO with setpoint of se(ven (7) inches USING the Data Table Access Module.

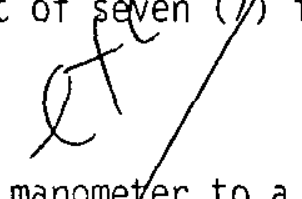

5.7.1.9 SET the test manometer to a pressure of 14" Water Gauge. 5.7.1.10 VERIFX that the fiaphragle Operated valve moves to a more OPEN
posidion.

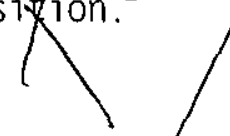

5.7.1.11 SET the test manometer to a pressure of 6" Water Gauge.

5.7.1.12 VERIFY that the Diaphragm Operated Valve moves to a more CLOSED position.

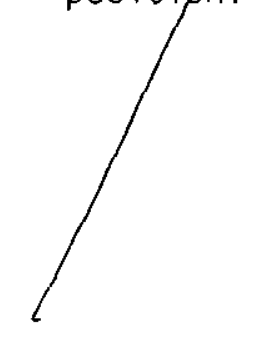

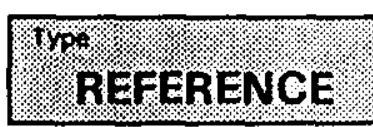

HNF-5820, Rev. 0

\section{pocument iso}

OTP-200-004 k4 1 19d

A. 16 setoupoato

$8 / 23 / 99$

page

48 of 108 


\subsection{DATA TABLE ACCESS MODULE AND OPERATOR CONTROL STATION} DIAPHRAGM OPERATED VALVE AUTOMATIC/MANUAL OPERATION (Cont.)

Test $\varepsilon \times C$ CP ${ }^{+}$' OPERATOR CONTROL STATION (AUTO)

5.7.15 ENSURE the Saltwell Pump and Jumper Assembly AND Pumping and

步1 Instrumentation Control Skid are CONFIGURED for AUTOMATIC Diaphragm operated Valve level control by PERFORMING the following:

5.7.15.1 SET the test manometer to a pressure of 0 " Water Gauge.

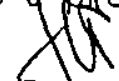

5.7.15.2 ENSURE the following val Re are
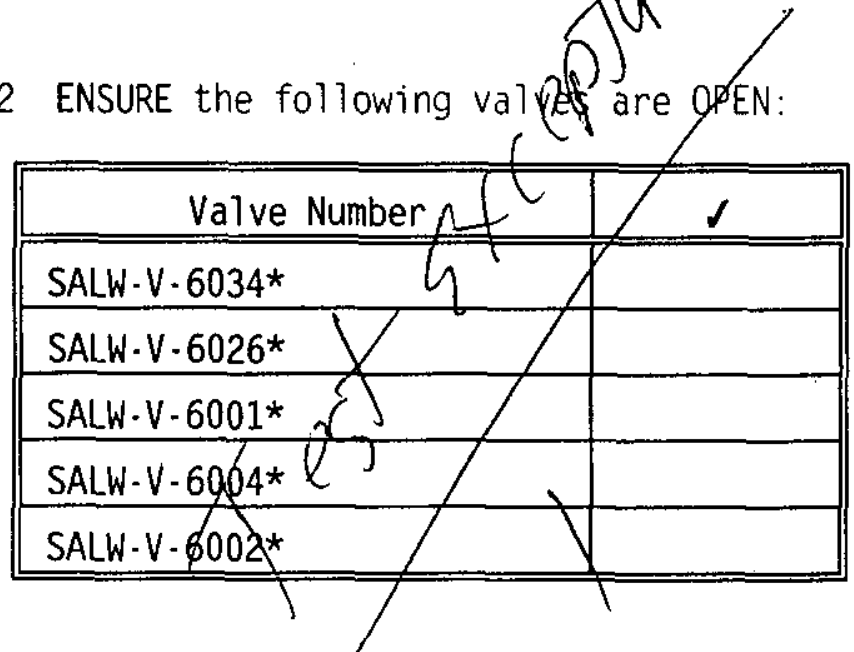

5.7.15.3 ENSURE the saltwell jumper JR-1 valve is in the PROCESS position.

5.7.15.4 At the discretion of the Test Director. ENSURE temporary interlock jumpers. OR software forces have been installed on pump peymissive interlocks for equipment not installed or out of service.

5.7.15.5 ENSWRE that only alarms "JET PUMP SHUTOOWN" and "SGT LOW" are displayed on the Operator Control Station.

5.7.15.6 ENSURE pump recirculation apparatus is filled with water AND CONFIGURED to circulate water through the saltwell Jet Purip.

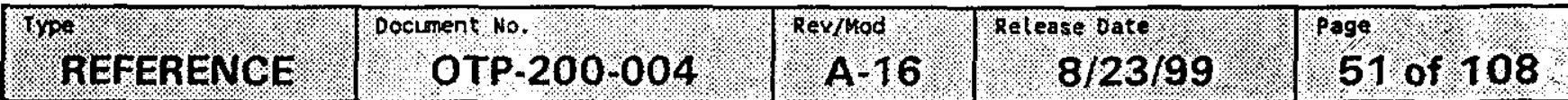


5.7 DATA TABLE ACCESS MODULE AND OPERATOR CONTROL STATION

testexe ptim DIAPHRAGM OPERATED VALVE AUTOMATIC/MANUAL OPERATION (Cont.)

\#2 1

5.7.15.8 SET the Specific Gravity Controller to AUTO with setpoint of 7.0 inches USING the Operator fontrol Station.

5.7.15.9 SET the test manometer to a pressure of 14 " water Gauge ( $\pm 1 "$ ). 5.7.15.10 VERIFY that dition.
pOsition.

5.7.15.11 SET the test manonieter to a pressure of 6" water Gauge.

5.7.15.12 VERIFY that the Diaphragm Operated Valve moves to a more CLOSED position.

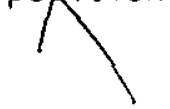

5.7.16 VERIFY that the MANUAL CONTROL of the Diaphragm Operated Valve is operational py PERFORMING the following steps:

5.7.16.1 SET the test manometer to a pressure of 15 " Water Gauge ( $\pm 1 "$ ).

5.7.16.2 SET the "DOV" Specific Gravity Controller to MANUAL CONTROL

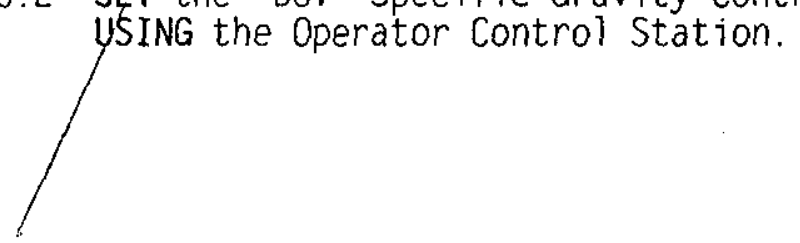

\begin{tabular}{|c|c|c|c|c|}
\hline fiper & Pocunent ro. & Rey/lod & Telease part & Prop 50 of 108 \\
\hline
\end{tabular}


5.7 DATA TABLE ACCESS MODULE AND OPERATOR CONTROL STATION DIAPHRAGM OPERATED VALVE AUTOMATIC/MANUAL OPERATION (Cont.)

Test

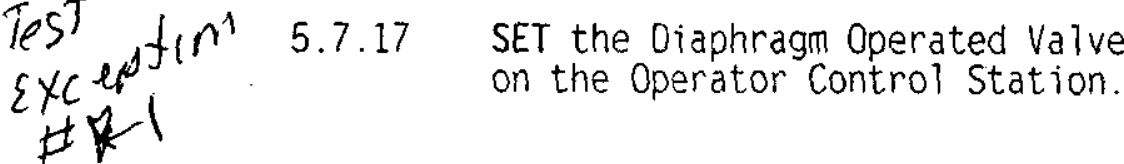
SET the Diaphragm Operated Valve to 0\% Open USING the manual control Exit

5.7.18 RECORD the following:

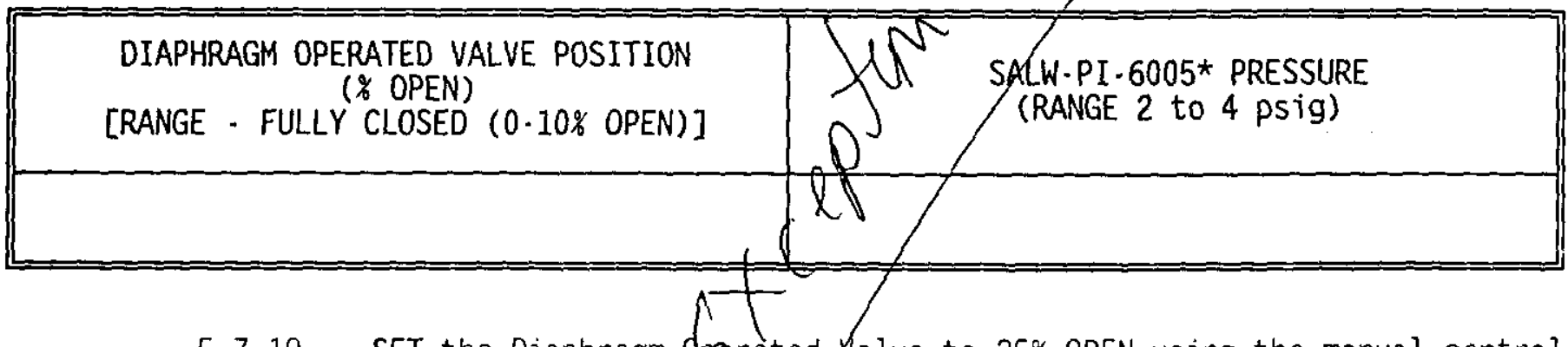

5.7.19 SET the Diaphragm deprated Xalve to 25\% OPEN using the manual control on the Operator Control Station.

5.7.20 RECORD the for froming:

\begin{tabular}{|c|c|}
\hline $\begin{array}{c}\text { DIAPHRAGM OPERATED VALVE ROSITION } \\
\text { (\% OPEN) } \\
\text { [RANGE: 15\% to 35\%] }\end{array}$ & $\begin{array}{c}\text { SALW-PI-6005* PRESSURE } \\
\text { (RANGE: 5 to 7 pSig) }\end{array}$ \\
\hline
\end{tabular}

5.7.21 SET the Diaphragm Operated Valve to 75\% OPEN using the manual control on the Operator Control Station.

5.7.22 RECORD the forlowing:

\begin{tabular}{|c|c|}
\hline $\begin{array}{c}\text { DIAPHRAGM OPERATEO VALVE POSITION } \\
(\% \text { OPEN) } \\
\text { [RANGE: 65\% to 85\%] }\end{array}$ & $\begin{array}{c}\text { SALW-PI-6005* PRESSURE } \\
\text { (RANGE: 11 to 13 pSig) }\end{array}$ \\
\hline
\end{tabular}

\begin{tabular}{|c|c|c|c|c|}
\hline REFERENCE & $\begin{array}{l}\text { Dociment Ho } \\
\text { OTP-200-004 }\end{array}$ & $\begin{array}{l}\text { Ravpod } \\
\text { A-16 }\end{array}$ & $\begin{array}{r}\text { Release date } \\
8 / 23 / 99\end{array}$ & $\begin{array}{ll}\text { goge } \\
53 \text { of } 108\end{array}$ \\
\hline
\end{tabular}




\subsection{DATA TABLE ACCESS MODULE AND OPERATOR CONTROL STATION}

DIAPHRAGM OPERATED VALVE AUTOMATIC/MANUAL OPERATION (Cont.)

Tests te apt 5.7.23 SET the Diaphragm Operated Valve to 100\% OPEN using the manual $\pm \&$ control on the Operator Control Station.

5.7.24 RECORD the following:

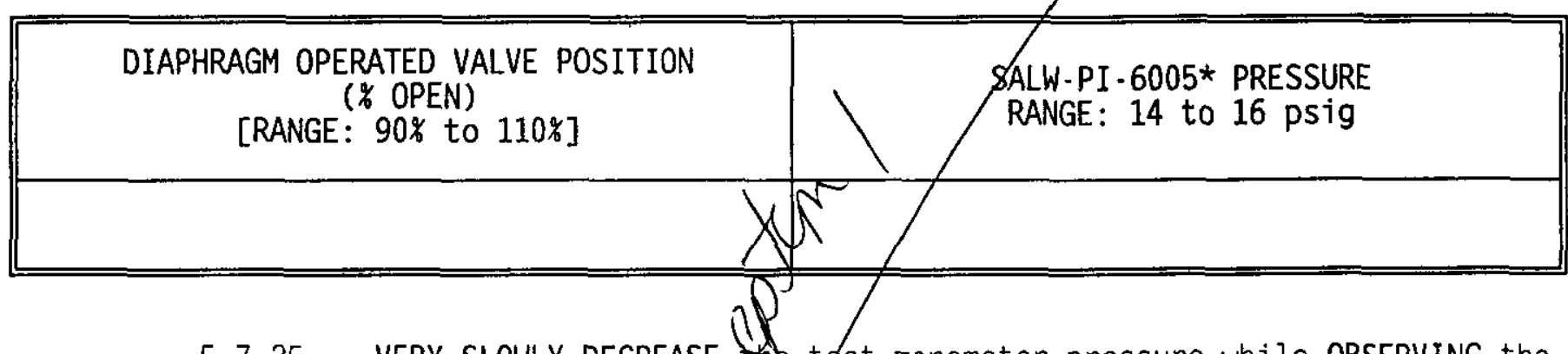

5.7.25 VERY SLOWLY DECREASE the test manometer pressure while OBSERVING the Diaphragm Operated Kalve.

5.7.26 VERIFY that the Oaphoagm Operated Valve remains FULLY OPEN while the test manometeX is DECKEASED UNTIL the Operator Control Station "SGT LOW" annunciates.

5.7.27 VERIFY that the diaphragm Operated Valve IMMEDIATELY CLOSES when the Operator Controy Station "SGT LOW" annunciates.

5.7.28 SHUTDOWN the Jet Pump with the Operator Control Station.

5.7.29 VERIFY the Jet Pump SHUT DOWN at the Operator Control Station.

\begin{tabular}{|c|c|c|c|c|}
\hline 8 & pocument fo. & Revihod & Retease bate & pago" \\
\hline
\end{tabular}


5.7 DATA TABLE ACCESS MODULE AND OPERATOR CONTROL STATION DIAPHRAGM OPERATED VALVE AUTOMATIC/MANUAL OPERATION (Cont.)

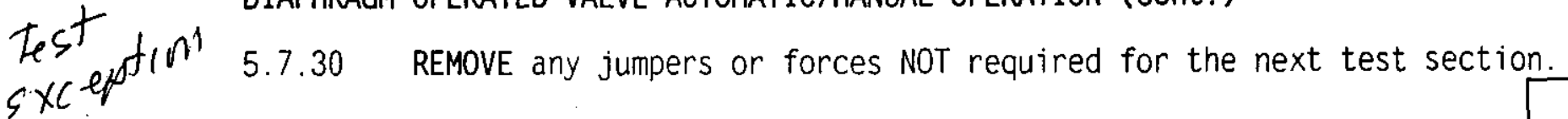
\# 1

5.7.31 Test Director VERIFY that section 5.7 is complete by SIGNING below. 5.7.32 Quality Control Inspegtor VERIFY that section 5.7 is complete by
signing below.

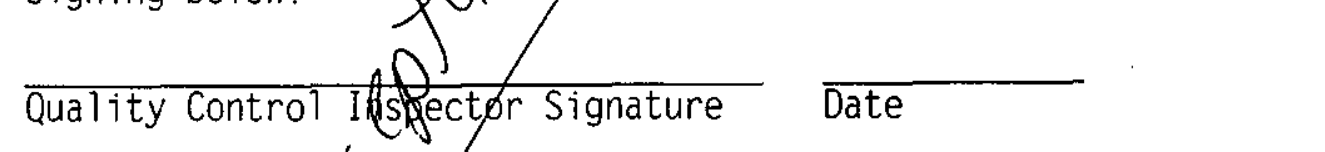




\subsection{JET PUMP FLOWMETER OPERATION}

Test Excersions.8.1

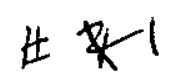

ENSURE that the Saltwell Jumper Flow Element is communicating properly with the FQIT SALW-FOIT-6001* (SUPERNATANT FLOW XMIT) and Data Table Access Module by PERFORMING the following:

5.8.1.1 PLACE the saltwell jumper JR-1 valve in the PROCESS position.

5.8.1.2 ENSURE Pump recirculation apparatus is filled with water AND configured to circulate water through the saltwell Jet Pump.

5.8.1.3 ENSURE the 0 - So font test/manometer is still attached to the high pressure dipetube AND set to 15 " Water Gauge ( $\pm 1 "$ ).

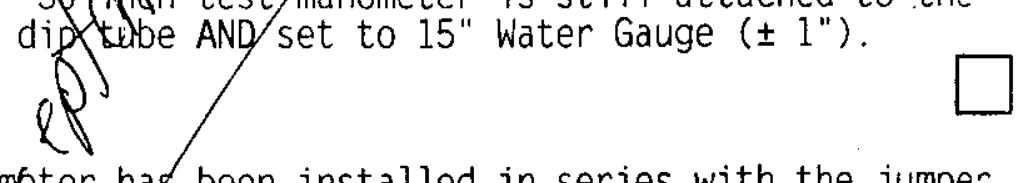

5.8.1.4 ENSURE a rotameter has been installed in series with the jumper flow element<smiles>C1CCC2CCCC2C1</smiles>

5.8.1.5 ENSURE that both the Data Table Access Module and Operator Controf Station are configured for MANUAL CONTROL.

5.8.1.6 At the discretion of the Test Director. ENSURE temporary inten lock dumpers. OR software forces are in place for uninstalled equipment.

5.8.1.7 SET the Diaphragm Operated Valve to O\% OPEN using the manual control on the Data Table Access Module.

5.8.1.8 ADJUST Jet Pump Jumper Valve JR-2 as directed by the Test oirector to achieve the required flow rates in the following steps.

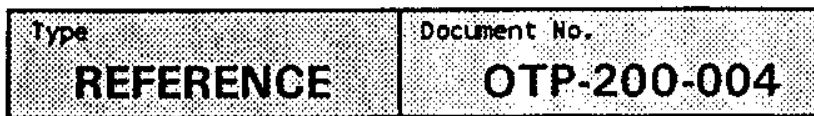

HNF-5820, Rev. 0

\begin{tabular}{|c|c|}
\hline evplyod & Release bato \\
\hline A-16 & $8 / 23 / 99$ \\
\hline
\end{tabular}

Poge

56 of 108 


\subsection{JET PUMP FLOWMETER OPERATION (Cont.)}

Test Exception 5.8.1.9 START the Jet Pump using the Data Table Access Module. H

5.8.1.10 VERIFY the start of the Jet Pump at the Operator Control Station.

5.8.2 RECORD initial readings, and the thime reading were taken.

\begin{tabular}{|c|c|c|}
\hline $\begin{array}{l}\text { DATA TABLE ACCESS MODULE } \\
\text { TOTALTZER (GaT1 ons) }\end{array}$ & ( & TIME \\
\hline & & \\
\hline
\end{tabular}

5.8.3 SET the Diapfragm Operated Valve Controller to MANUAL AND ADJUST Controller at the oata Table Access Module to obtain a flowrate of APPROXIMÃTELY 1.0 GPM $( \pm 0.05 \mathrm{gpm})$ through the jumper.

5.8.4 RECORD the folfowing:

\begin{tabular}{|c|c|c|c|c|c|c|c|c|}
\hline $\begin{array}{l}\text { DTAM MANUAL } \\
\text { CONTROL DOV } \\
\text { POSITION }(\%)\end{array}$ & $\begin{array}{c}\text { OCS MANUAL } \\
\text { CONTROL } \\
\text { DOV } \\
\text { POSITION } \\
(\%)\end{array}$ & $\begin{array}{l}\text { oov } \\
\text { POSITION } \\
\text { (\% OPEY) }\end{array}$ & $\begin{array}{l}\text { TEST } \\
\text { ROTAMETER } \\
\text { FLOWRATE } \\
\text { (GPM) }\end{array}$ & $\begin{array}{l}\text { (INSTR) } \\
\text { FQIT } \\
\text { FLOWRATE } \\
\text { (GPM) }\end{array}$ & $\begin{array}{l}\text { DTAM } \\
\text { FLOHRATE } \\
\text { (GPM) }\end{array}$ & $\begin{array}{l}\text { OCS } \\
\text { FLOWRATE } \\
\text { (GPM) }\end{array}$ & $\begin{array}{l}\text { DTAM } \\
\text { TOTALIZER } \\
\text { (GALLONS) }\end{array}$ & $\begin{array}{c}\text { FOIT } \\
\text { TOTALIZER } \\
\text { (GALLONS) }\end{array}$ \\
\hline & & & & & & & & \\
\hline
\end{tabular}

5.8.5 VERAFY that Test Rotameter flowrate. FQIT SALW-FQIT-6001* flowrzte. Data Table Access Module flowrate. AND Operator Control Station flowrate are within $\pm 0.1 \mathrm{gpm}$. 


\subsection{JET PUMP FLOWMETER OPERATION (Cont.)}

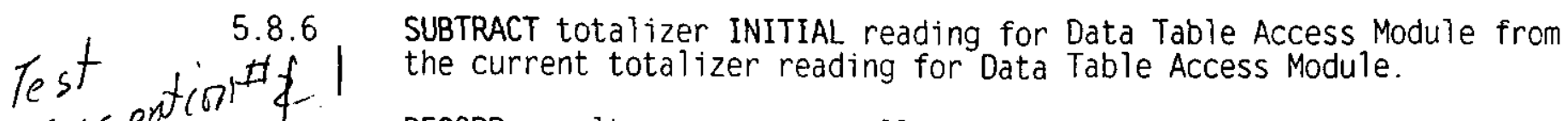

RECORD result: gallons 5.8.7 SUBTRACT INITIAL totalizer reading for FQIT from the current
totalizer reading for the FQIT.

RECORD result:

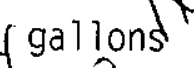

5.8.8 VERIFY results from the apove two steps are within \pm 5.0 gallons.

5.8.9 ADJUST the Diaphragm Operated Valve Controller to obtain a flowrate of APPROXIMATELY 2 GPM $(\neq 0.125 \mathrm{gpm})$ through the jumper.

5.8.10 RECORD the following:

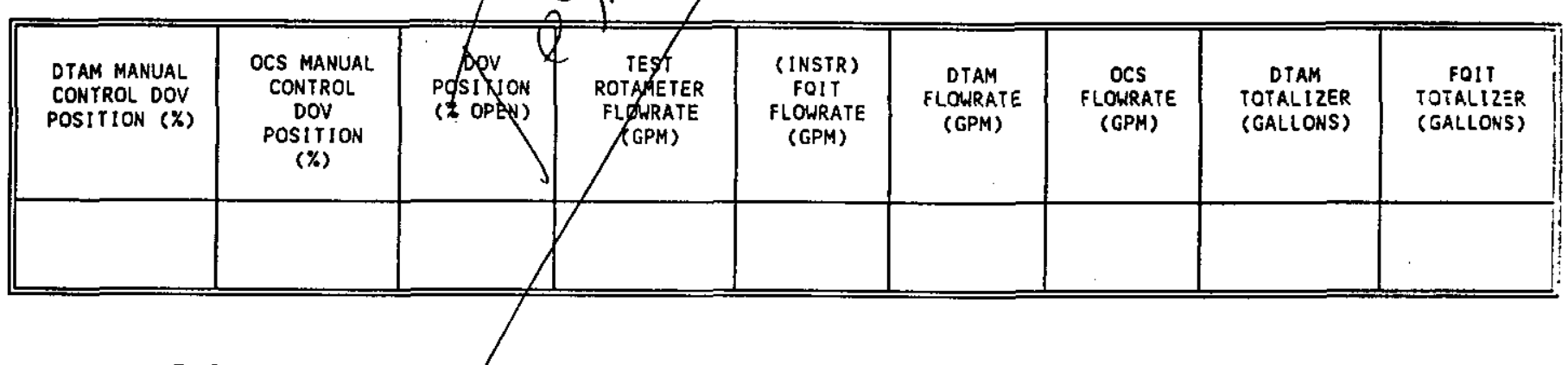

5.8.11 VERIFY that Test Rotameter flowrate. FQIT SALW-FQIT-6001* flowr Data Table Access Module flowrate. AND Operator Control Station flowrzte are within $\pm 0.25 \mathrm{gpm}$.

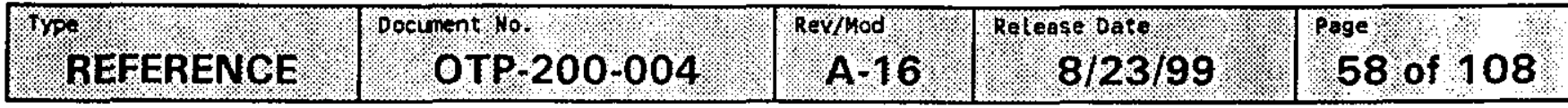




\subsection{JET PUMP FLOWMETER OPERATION (Cont.)}

Test Exceptin 5.8 .12 Hz

SUBTRACT totalizer INITIAL reading for Data Table Access Module from the current totalizer reading for Data Table Access Module.

RECORD result: gallons

5.8.13 SUBTRACT INITIAL totalizer reading totalizer reading for the FQIT.

RECORD result:

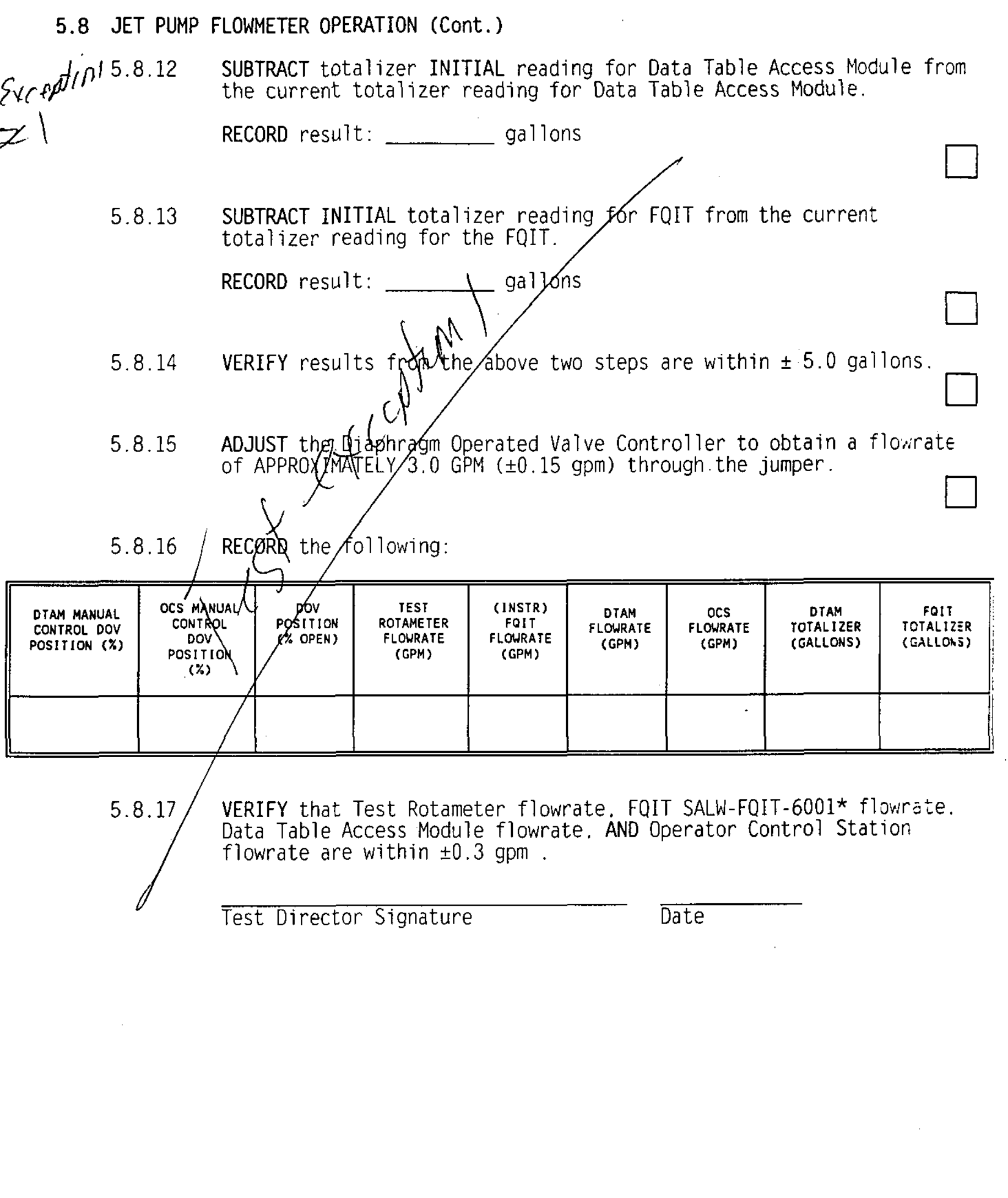

5.8.14 VERIFY results frothe/above two steps are within \pm 5.0 gallons.

5.8.15 ADJUST the Giaphragm Operated Valve Controller to obtain a flowrate of APPROXMATELY $3.0 \mathrm{GPM}( \pm 0.15 \mathrm{gpm})$ through the jumper.
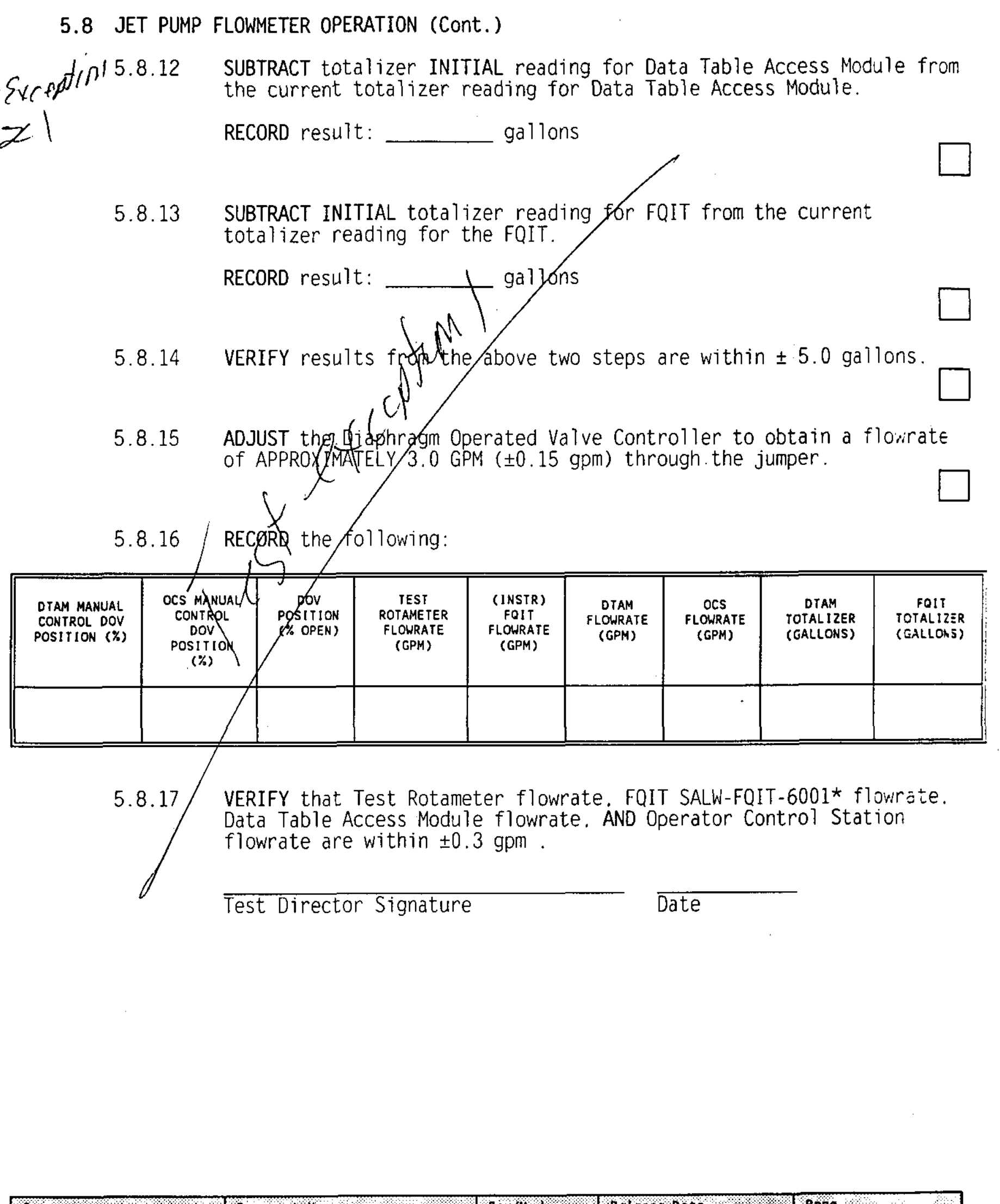

\section{REFERENCE}




\subsection{JET PUMP FLOWMETER OPERATION (Cont.)}

Tes $f$ Exc of 5.8 .18 SUBTRACT totalizer INITIAL reading for Data Table Access Module from $+1$ the current totalizer reading for Data Table Access Module.

RECORD result: gallons

5.8.19 SUBTRACT INITIAL totalizer reading for FQIT from the current totalizer reading for the FQIT.

RECORD result: gallons

5.8.20 VERIFY results from the abovel two gteps are within \pm 5.0 galions.

5.8.21 CLOSE the Diaphragm Operdted Yalve (to 0\%) using the manual Diaphragm Operated Valve control.

5.8.22 VERIFY JR-2 is CLOSED.
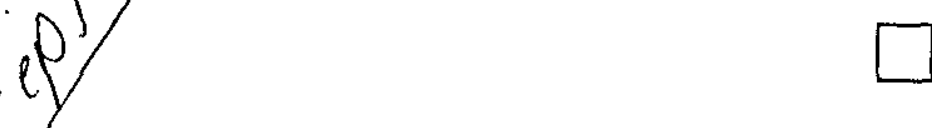

5.8.23 RECORD the following:

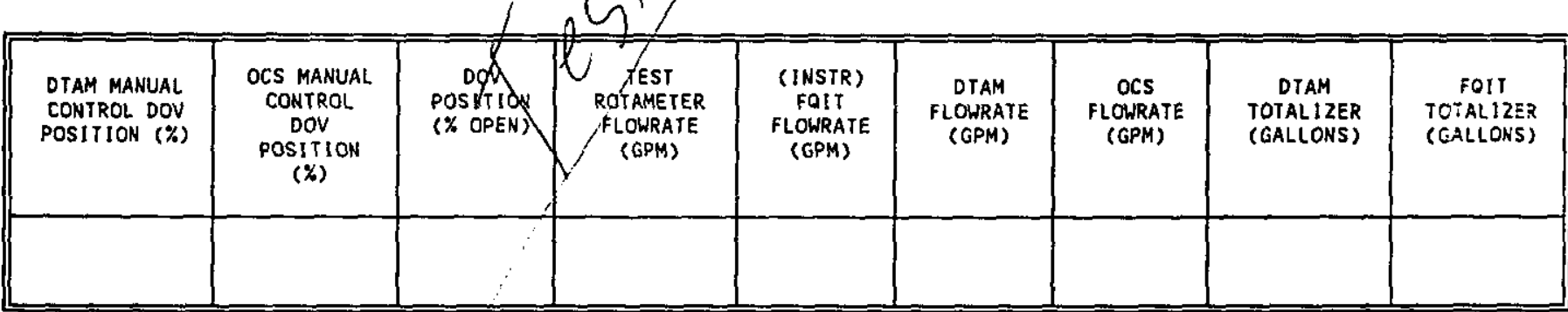

5.8.24 VERIFY that Test Rotameter flowrate. FOIT SALW-FQIT-6001* flowrate, Data Table Access Module flowrate, AND Operator Control Station flowrate all indicate $0.0 \mathrm{gpm}( \pm 0.1 \mathrm{gpm})$. 


\subsection{JET PUMP FLOWMETER OPERATION (Cont.)}

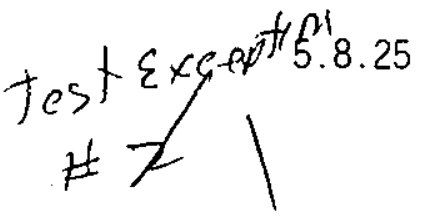

SUBTRACT totalizer INITIAL reading for Data Table Access Module from the current totalizer reading for Data Table Access Module.

RECORD result: galions

5.8.26 SUBTRACT INITIAL totalizer readting for FQIT from the current totalizer reading for the ElIT.

RECORD result:

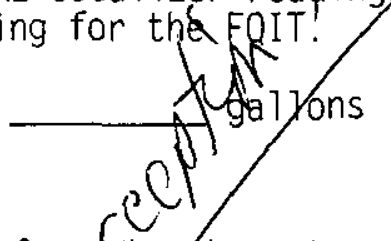

5.8.27 VERIFY results front the above two steps are within \pm 5.0 gallons.<smiles>C1=CC2CCCCC2C1</smiles>

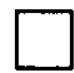

5.8.28 USING the gata Tabje Access Module. STOP the Jet Pump.

5.8.29 REMoke the test manometer.

5.8.30 ISOLATE the Specific Gravity Transmitter from the system.

NOTE - Al three valves are located on the Specific Gravity Transmitter three valve manifold SALW-V-6035*.

5.8.30.1 OPEN the equalization valve for the Specific Gravity Transmitter.

5.8.30.2 CLOSE the two (2) isolation valves.

\begin{tabular}{|c|c|c|c|c|}
\hline TYPr: REFERENCE & $\begin{array}{l}\text { pociment No. } \\
\text { OTP.200-004 }\end{array}$ & $\begin{array}{l}\text { Revphod: } \\
\text { A. } 16\end{array}$ & $\begin{array}{l}\text { Rélease date } \\
8 / 23 / 99\end{array}$ & Prof of 108 \\
\hline
\end{tabular}




\subsection{JET PUMP FLOWMETER OPERATION (Cont.)}

5.8.31 REMOVE any jumpers or forces NOT required for the next test section.

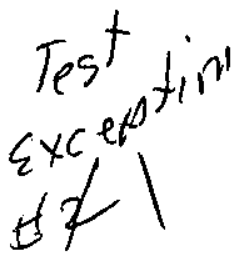

5.8.32 Test Director VERIFY that section 5.8 is Complete by SIGNING below.

5.8.33 Quality Control Inspector VERIFY/that section 5.8 is complete by signing below.

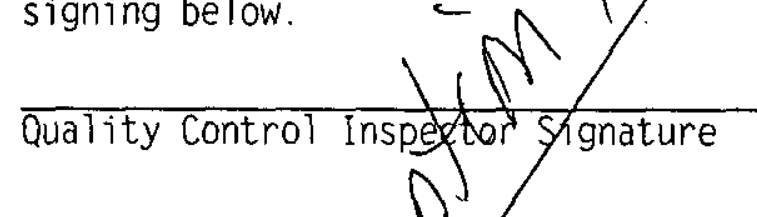

$\overline{\text { Date }}$

\begin{tabular}{|c|c|c|c|c|}
\hline REFERENCE. & oochent & Aerrod & qereaserate & 102 of 108 \\
\hline
\end{tabular}




\subsection{JET PUMP VALVING INTERLOCK FOR THE JET PUMP}

5.9.1 ENSURE PUIn recirculation apparatus is filled with water AND

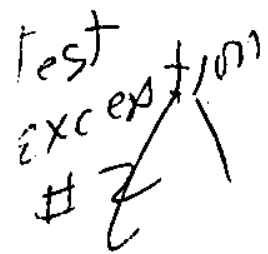
configured to circulate water through the saltwell. Jet Pump.

5.9.2 ENSURE all alarms have been acknowledged at the Data Table Access Module and Operator Control Station.

5.9.3 At the discretion of the Test Directdr. ENSURE temporary inter lock jumpers. OR software forces have been installed on pump permissive interlocks for equipment not instriled or out of service.

5.9.4 USING the Data Table Access Madule/. START the Jet Pump.

5.9.5 VERIFY Jet Pump operation at the Operator Control Station.

5.9.6 PLACE the JR-1 Valve on the Jet Pump jumper. in the FLUSH position.

5.9.7 VERIFY the following:

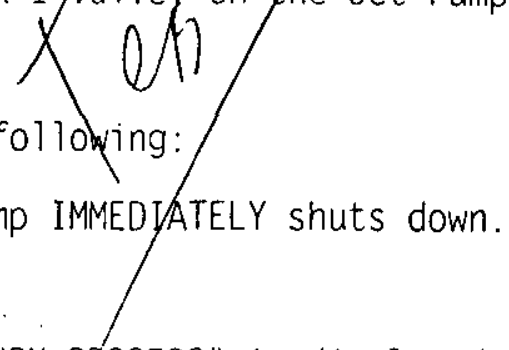

- Jet Pump IMMEDIATELY shuts down.

- "JR-1 NON-PROCESS" is displayed at Data Table Access Module AND "NOT PROCE\&S" is displayed operator control Station.

"Jet Punp SHUTOOWN" is displayed at Data Table Access Module and Operator Control Station.

NOTE - "Flush Pressure HI" may be received.

5.9.8 VERIFY the Jet Pump can not be re-started with the JR-1 valve ir the FLUSH position.

4. REFERENCE .




\subsection{JET PUMP VALVING INTERLOCK FOR THE JET PUMP (Cont.)}

5.9.9 PLACE the JR-1 Valve in the PROCESS position.

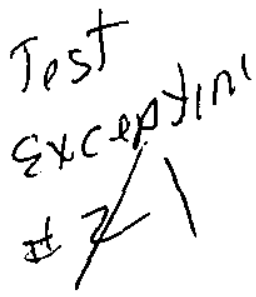

5.9.10 ENSURE all alarms have been acknowledged at the Data Table Access Module and Operator Control Station.

5.9.11 RESTART the jet Pump using the Data Table Access Module.

5.9.12 VERIFY Jet Pump operation at the Operator Control Station.
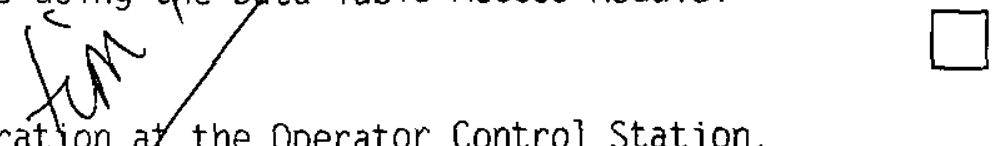

5.9.13 PLACE the JR-1 Votve id the PRIME position.

5.9.14 VERIFY the following:

- Jet cump imdEDIATELy shuts down.

- "JR-1 NON-PROCESS" is displayed at Data Table Access Module AND operator Control Station (ALARM *5).

- "Jet Pump SHUTDOWN" is displayed at Data Table Access Moduie and Operator Control Station (ALARM *12).

NOTE - "FLUSH Pressure HI" may be received.

5.9.15 VERIFY the Jet Pump can not be re-started with the JR-1 valve in the PRIME position.<smiles>C1CCC1</smiles>

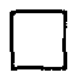

5.9.16 ENSURE all alarms have been acknowledged at the Data Table Access Module and Operator Control Station. 


\subsection{JET PUMP VALVING INTERLOCK FOR THE JET PUMP (Cont.)}

Test

5.9.17 REMOVE any jumpers or forces NOT required for the next test section Exceptiol 5.9.18 Test Director VERIFY that section 5.9 is complete by SIGNING below. से)

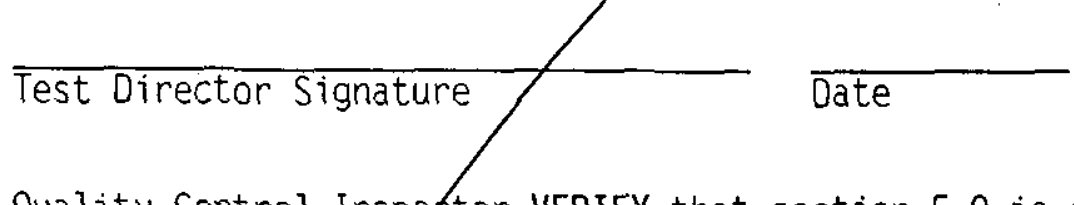

5.9.19 Quality Control Inspector VERIFY that section 5.9 is complete by signing below.

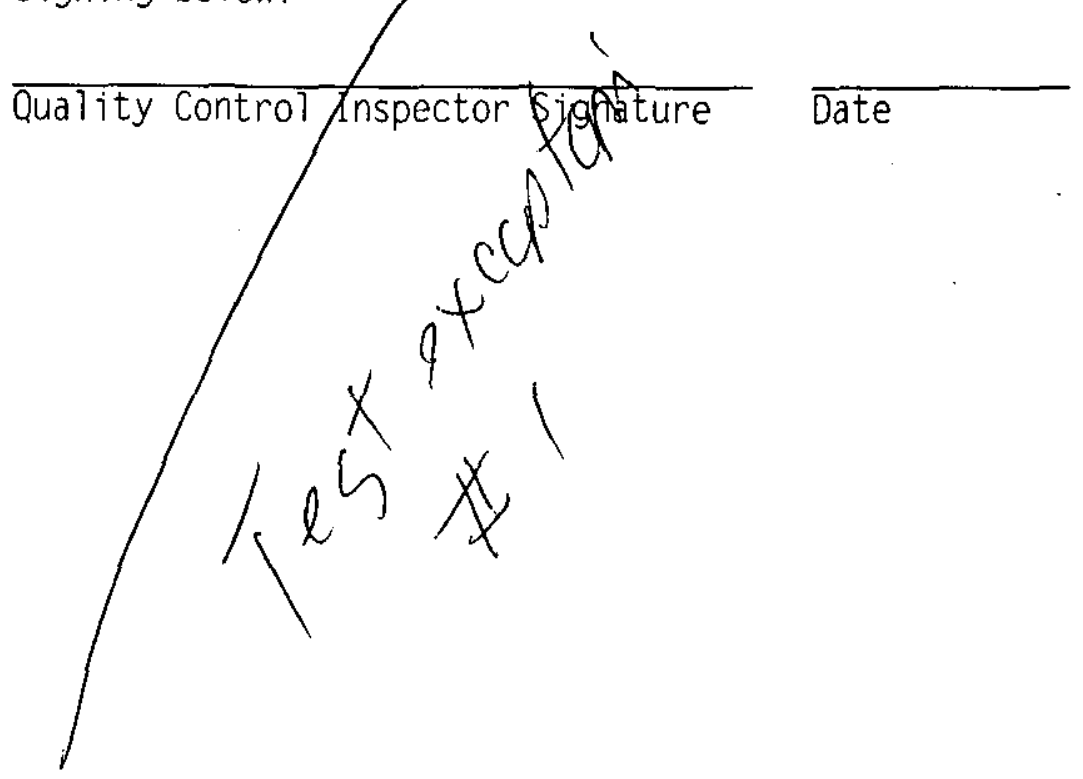




\subsection{OPERATOR CONTROL STATION JET PUMP SHUTDOWN TEST}

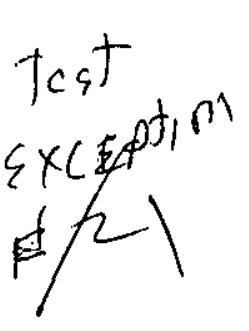

5.10.1 PLACE the Jet Pump JR-1 valve in the PROCESS position.

5.10.2 ENSURE Pump recirculation apparatus is fylled with water AND configured to circulate water through the saltwell Jet Pump.

5.10.3 ENSURE no interlocks are present that will prevent pump operation. - At the discretion of the Jest Director. jumper or force interlocks if necessary.

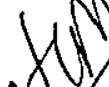

5.10.4 Using the Data Table Adcess Module. START the Jet Pump.

5.10.5 VERIFY Jet Pumpgiperation at the Operator Control Station.

5.10.6 Using the Offrator Control Station. SHUT DOWN the Jet Pump.

5.10.7 VERIFX the JUT PUMP SHUTDOWN alarm at the Operator Control Station.

5.10.8 Test Director VERIFY that section 5.10 is complete by SIGNING below.

5.10.9 Qua ity Control Inspector VERIFY that section 5.10 is complete by signing below.

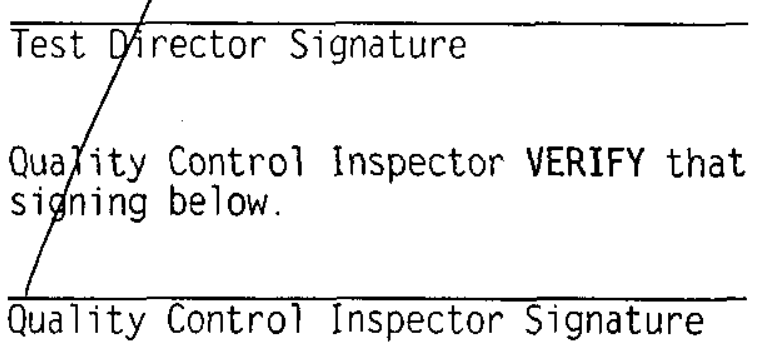

Date

Date

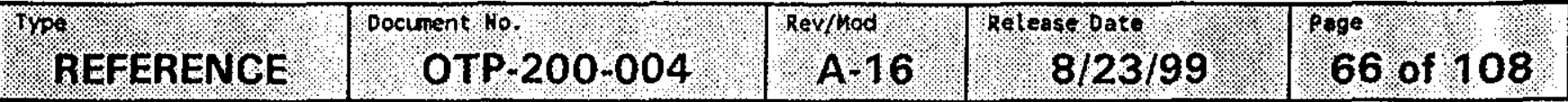




\subsection{LEAK DETECTION INTERLOCK CHECK}

5.11.1 Cognizant Engineer shall LIST all relevant leak detectors in pump pit. valve pits. clean out boxes, and encasements along transfer route in the table below. Any unused lines in the table shall be marked with an "N/A".

NOTE - Leak Detector Interlock checks can be performed in any sequence.

Operator Control Station wording of alarms may be different than Data Table Access Module, but must have the same general meaning.

Pump operation will be simulated during the remainder of the OTP.

5.11.2 VERIFY current functional check. AND RECORD the due date on the table below.

NOTE - Leak detectors not associated with the skid being tested shall be marked as "N/A".

\begin{tabular}{|c|c|c|}
\hline INSTRUMENT & $\begin{array}{l}\text { FUNCTIONAL CHECK } \\
\text { DATE }\end{array}$ & NEXT DUE DATE \\
\hline 1) Drumiery haik Defectik & $9-22-99$ & $24+2 / 44$ \\
\hline 2) L Las Detectura & $9-22-99$ & $12-99$ \\
\hline 3) $S A L W-\angle D E C(1-B$ & $9-22-9 q$ & 12.99 \\
\hline 4) $S A L V K-\angle D E-C O B-U 33$ & $9-22.99$ & $12-99$ \\
\hline 5) $\angle A C V(V-C D E-U-D)$ & $9-22-99$ & $12-9 \varepsilon$ \\
\hline 6) $\angle A C H-\angle D E-\angle O B 30$ & $9-22-99$ & $12-99$ \\
\hline 7) $\operatorname{SA} L u=\angle D F-\angle A$ & $9-20 \cdots 99$ & $12-98$ \\
\hline 8) $S H C W . \angle D E-S Y O Z A 1$ & $9-20-99$ & $12-99$ \\
\hline 9) $; A \angle M C-\angle D E-S-B$ & $9-20 \cdot 99$ & $12-94$ \\
\hline \multicolumn{3}{|l|}{ 10) } \\
\hline \multicolumn{3}{|l|}{ 11) } \\
\hline \multicolumn{3}{|l|}{ 12) } \\
\hline \multicolumn{3}{|l|}{ 13) } \\
\hline \multicolumn{3}{|l|}{ 14) } \\
\hline 15) & & \\
\hline
\end{tabular}

\begin{tabular}{|c|c|c|c|c|}
\hline REFERE & $\begin{array}{l}\text { Document fio } \\
\text { OTP-200-004 }\end{array}$ & $\begin{array}{c}\text { Reviliod } \\
\text { A-16 }\end{array}$ & $\begin{array}{c}\text { Release batti } \\
8 / 23 / 99\end{array}$ & 67 of 108 \\
\hline
\end{tabular}




\subsection{LEAK DETECTION INTERLOCK CHECK (Cont.)}

NOTE - 242-A Evaporator Operator only needs to be notified for East Area transfers.

5.11.3 IF required. NOTIFY the Tank Monitoring and Control System Operator. 242-A Evaporator Operator and Shift Manager that this section is about to commence.

5.11.4 REQUEST Test Director to VERIFY that field installation of the Saltwell equipment per applicable work package is completed for

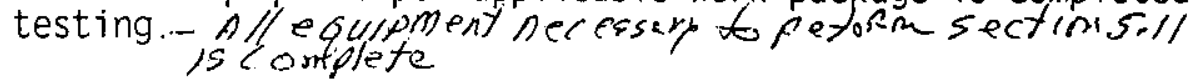

NOTE - FOr EMERGENCY PUMPING SKID, or testing of skid prior to field installation. Test Director sha1l "NA" the work package number line and sign and date where requested.

Enter work package number $\omega s-\varphi Q-00 / 4 / 6$

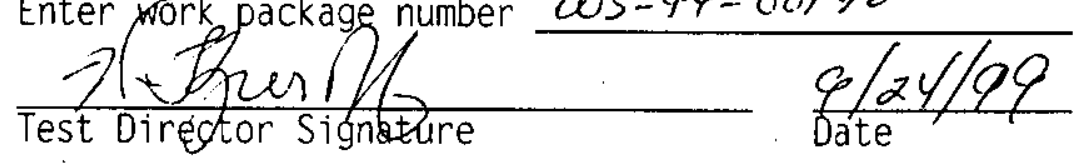

\begin{tabular}{|c|c|c|c|c|}
\hline REPERENCF & Docinent ro: & Revplod & Relense pato: 810 & 68 \\
\hline
\end{tabular}




\subsection{LEAK DETECTION INTERLOCK CHECK (Cont.)}

5.11.5 CHECK the leak detector inter locks corresponding to the leak detectors entered in the previous Table by the Cognizant Engineer by PERFORMING step 5.11.5.1 through step 5.11.5.11 AND CHECKING the appropriate space when complete:

\begin{tabular}{|c|c|c|}
\hline \multirow{16}{*}{$\begin{array}{l}\text { Test excupt } \\
\text { It } 1\end{array}$} & LEAK DETECTOR & $\begin{array}{l}\text { CHECK COMPLETE } \\
(\checkmark)\end{array}$ \\
\hline & 1) Primirg leak Detector & 2 \\
\hline & 2) Leak Dutector I & ! \\
\hline & 3) $S A L U-\angle D E-6 \theta U-B$ & \\
\hline & 4) $S A L w-L D E-\cos 33$ & \\
\hline & 5) $\angle A L N-\angle D E-\angle D$ & \\
\hline & 6) $S A L W-\angle D E-\operatorname{COB} 30$ & \\
\hline & 7) $S A C w-4) E-\angle \times t \operatorname{sy} A^{w} 3 / 3599$ & FAIC \\
\hline & 8) $S A W-\angle D E-5 Y 0 Z A$ & $F A, L$ \\
\hline & 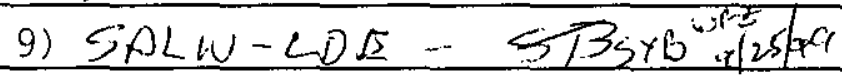 & $F A_{1} L$ \\
\hline & 10) & \\
\hline & 11) & \\
\hline & 12) & \\
\hline & 13) & \\
\hline & 14) & \\
\hline & 15) & \\
\hline
\end{tabular}

5.11.5.1 IF REQUIRED, ENSURE the Pump Instrument and Control Skid is configured and ready to receive leak detector signal.

5.11.5.2 MONITOR the status of the Pump Starter to VERIFY pump status.

5.11.5.3. IF test is to be performed after pump installation. ENSURE Jet Pump motor leads have been determinated from the load side of the starter while performing this section.

W.




\subsection{LEAK DETECTION INTERLOCK CHECK (Cont.)}

5.11.5.4 ENSURE no interlocks are present that will prevent pump operation.

- At the discretion of the Test Director. force or jumper unused inter locks.

5.11.5.5 Using Data Table Access Module. START the Jet Pump.

NOTE - Programmer may need to force limit switches and pressure switches to simulate recirculate flow.

5.11.5.6 VERIFY Jet Pump start at Operator Control Station. 


\subsection{LEAK DETECTION INTERLOCK CHECK (Cont.)}

\section{WARNING}

Energized circuits and leads are contained inside the cabinet.

observe appropriate electrical. Comply with WHC-CM-1-10. WKS-15.

ELECTRICAL WORK SAFETY to avoid personnel electrical shock hazards.

5.11.5.7 TEST leak detector using Leak Detector Test Circuit OR jumper. or by emerging probe, as required. VERIFY and ACKNOWLEDGE the following:

- IMMEOIATE Jet Pump shutdown.

- $\quad$ "JET PUMP SHUTDOWN" is annunciating at the Data Table Access Module (ALARM \#12).

- A Leak Detection Alarm is annunciating at the Data Table Access Module AND at the Operator Control Station.

5.11.5.8 ACKNOWLEDGE the Leak Detector Alarm at the Operator Control Station.

5.11.5.9. ACKNOWLEDGE the Leak Detector Alarm at the Data Table Access Module.

5.11.5.10 VERIFY that the Jet Pump CAN NOT be re-started at the Data Table Access Module when the alarm is ACTIVE.

5.11.5.11 RETURN the reak detector to a condition of operation by PERFORMING the following:

- IF a jumper was installed in step 5.11.5.7. REMOVE jumper.

- VERIFY the Leak Detection Alarm at the Data Table Accミss Module and Operator Control Station resets.

- $\quad$ RESET the remote Master Pump Shutdown if required. 
5.11 leak detection interlock check (cont.) Master Pump Shut dow NOTE - Steps 5.11.6 through 5.11.15 only need to be performed if remote Master Pump Shutdown exists. does nof axis

5.11.6 RESTART the Jet Pump using Data Table Access Module.

5.11.7 SHUTDOWN the Jet Pump using the manual Master Pump Shutdown.

5.11.8 VERIFY that the Jet Pump stops AND the Leak Detection Alarm appears

5.11.9 ACKNOWLEDGE alarms at the Data Table Access Module and Operator Control Station.

5.11.10 RESET the Master Pump Shutdown.

5.11.11 RESTART the Jet Pump using the Data Table Access Module.

5.11.12 SHUTDOWN the Jet Pump using the manual Master Pump Shutdown at a second location (if it exists).

5.11.13 VERIFY that the Jet Pump stops AND Leak Detection Alarm appears.

5.11.14 RESET the Master Pump Shutdown.

5.11.15 ACKNOWLEDGE alarms at the Data Table Access Module and Operator Control Station. 


\subsection{LEAK DETECTION INTERLOCK CHECK (Cont.)}

INTERLOCK TEST

NOTE - It is the intent of this section to test all transfer system and FGM interlocks not previously tested in the leak detector section.

Included would be DCRT high level alarms, dilution tank low level alarms. FGM alarms. and leak detection not previously tested. Also included would be encasement and receiver tank pressurization alarmis.

The Cognizant Engineer is responsible for reviewing the installation design and identifying all appropriate interlocks to be tested.

5.11.16 Cognizant Engineer shall ENTER all interlocks (by relay or device designation) not tested by a separate section in the Table below.

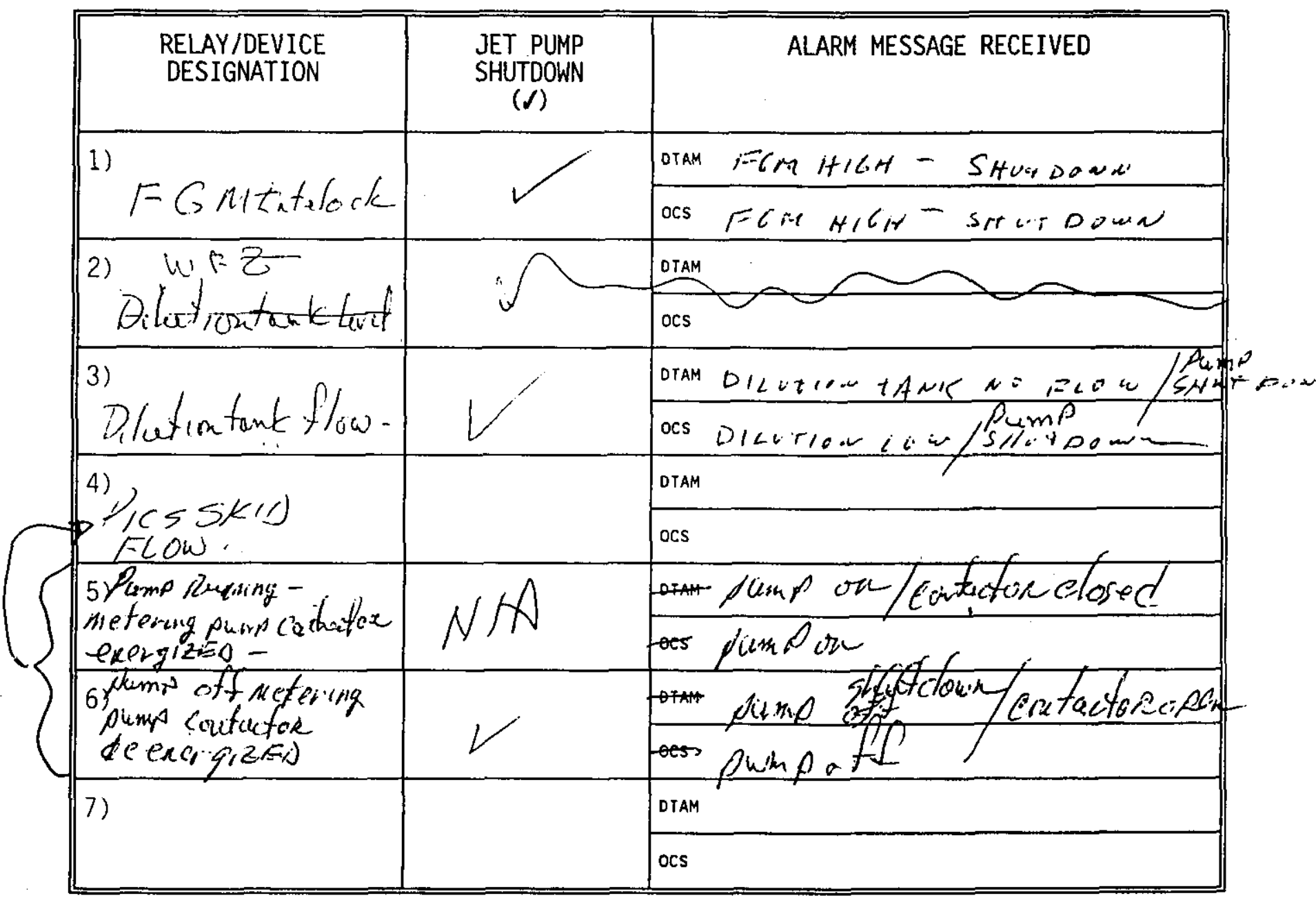

\begin{tabular}{|c|c|c|c|c|}
\hline ppe & Docimen: ko. & Rey/Mod & Releose oate & P290 \\
\hline
\end{tabular}




\section{11 LEAK DETECTION INTERLOCK CHECK (Cont.)}

\section{WARNING}

Energized circuits and leads are contained inside the cabinet.

observe appropriate electrical. Comply with WHC-CM-1-10. WKS-15.

ELECTRICAL WORK SAFETY to avoid personnel electrical shock hazards.

5.11.17 NOTIFY Tank Monitoring and Control System Operator, 242-A Evaporator Operator (if transfer is in east Area), and Shift Manager that this section is about to begin.

5.11.18 For each relay listed in the Table above. PERFORM the following:
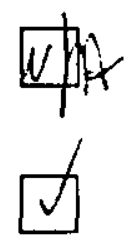

5.11.18.1 Using the Data Table Access Module. START the Jet Pump. AND OBSERVE that the pump run light is $O N$.

5.11.18.2 DEACTIVATE the relay to simulate an alarm condition.

NOTE - Craft will determine a safe method of deactivating each device. Test pushbuttons, mock input signals, shorting across secondary of induction relay coils. lifting coil leads. or pulling device from socket may be used.

5.11.18.3 VERIFY Data Table Access Module and Operator Control Station display "JET PUMP SHIUTDOWN" AND an interlock message.

5.11.18.4 RECORD a check mark in the Table if Jet Pump shutdown occurs.

5.11.18.5 RECORD the interlock alarm messages received at Data Table Access Module and Operator Control Station in the Table.

5.11.18.6 VERIFY that the Jet Pump CAN NOT be re-started at the Data Tabie Access Module when the alarm is ACTIVE.

5.11.18.7 RESTORE the circuit (remove simulated alarm condition).

5.11.18.8 ACKNOWLEDGE the alarms at Data Table Access Module and Operator Control Station.

\begin{tabular}{|c|c|c|c|c|}
\hline REFERENCE & $\begin{array}{l}\text { Pocument ro. } \\
\text { OTP-200-004 }\end{array}$ & Revjuod 16 & Releace bato $8 / 23 / 99$ & 74 of 108 \\
\hline
\end{tabular}




\subsection{LEAK DETECTION INTERLOCK CHECK (Cont.)}

5.11.19 NOTIFY Tank Monitoring and Control System Operator. 242-A Evaporator Operator (if transfer is in east Area), and Shift Manager that this section is complete.

5.11.20 REMOVE any jumpers or forces NOT required for the next test section

5.11.21 Test Director YERIFX that section 5.11 is complete by SIGNING below.

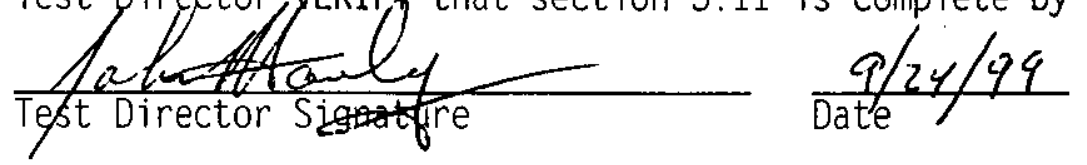

5.11.22 Quality Control Inspector VERIFY that section 5.11 is complete by signing below.

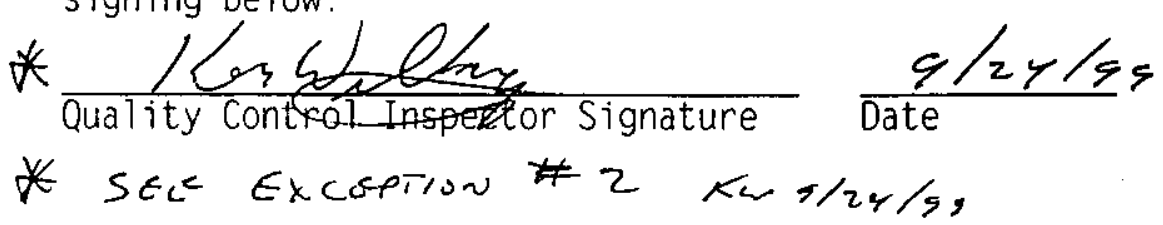




\subsection{SHUTDOWN CIRCUITRY CHECK}

NOTE - This section will only be performed at Tanks requiring a shutdown

$N / d$ circuit.

5.12.1 At the discretion of the Test Director. ENSURE temporary inter lock jumpers. $O R$ software forces are in place for uninstaljed equipment.

5.12.2 PRESS the SEISMIC RESET PB-1 push-button (located on the SAFETY CLASS CONTROL CABINET (B)).

5.12.3 ENSURE the POWER AVAIL BLUE indicating light (located on the SAFETY

5.12.4 IF FGM. Exhauster or Dome Pressure transmitters are NOT in service. PLACE jumpers acrosS FGMI-1 and VENT-2 on TB-1 of SAFETY CLASS CONTROL CABINET (A) AND across terminal 7 and 9 of dome pressure alarm module.

5.12.5 PRESS the PANEL RESE 12 push-button (1ocated on the SAFETY CLASS

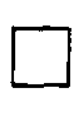

\section{CLASS CONTROL CABINET $(B)$ ) is illuminated.} CONTROL CABINET (A)).
5.12.6 ENSURE the TRIP CKY FUNCTIONAL GREEN indicating light (located on the SAFETY CLASS CONTROL CABINET (B)) is illuminated.

\section{SEISMIC SWITCH TEST}

5.12.7 SIMULATE on earthquake alarm condition at the panel containing SAFETY CLASS CONTROL CABINET (A) and SAFETY CLASS CONTROL CABINET (B) per Test Djrector instructions.

5.12.8 VERIFY that the HT-1-1 contactor (located in cabinet "SAFETY CLFSS AEAT TRACE CONTACTOR HT-1") is OPEN.

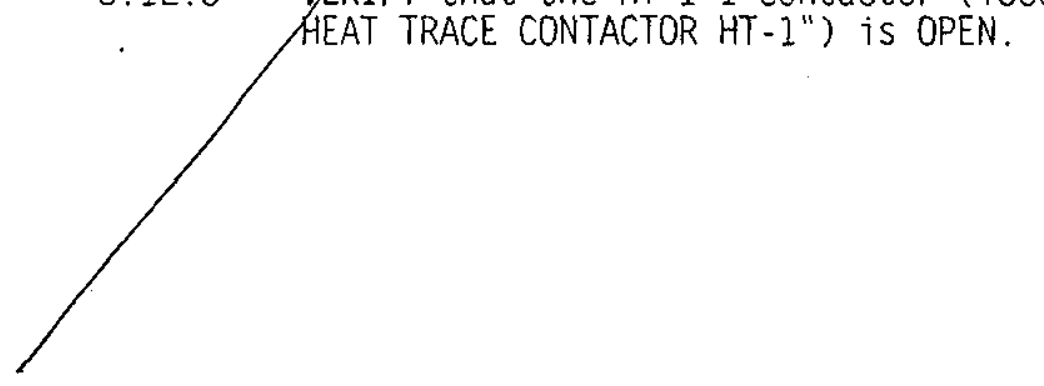

\begin{tabular}{|c|c|c|c|c|}
\hline TPR REFERENCE & OTP $200-004$ & Rey/Mod & Release fate & 76 of 108 \\
\hline
\end{tabular}




\subsection{SHUTDOWN CIRCUITRY CHECK (Cont.)}

5.12.9 VERIFY that the PMP-1-1 contactor (located in cabinet "SAFETX CLASS PUMP CONTACTOR PMP-1") is OPEN.

5.12.10 VERIFY that the HT-2-1 contactor (located in cabinet/"SAFETY CLASS HEAT TRACE CONTACTOR HT-2") is OPEN.

5.12.11 VERIFY that the PMP-2-1 contactor (located in cabinet "SAFETY CLASS PUMP CONTACTOR PMP-2") is OPEN.

5.12.12 VERIFY that the "SEISMIC SWITCH" alarm is activated on the Data Table Access Module (ALARM \#27)

5.12.13 PRESS the SEISMIC RESET RB pusp-button (located on the SAFETY CLASS CONTROL CABINET (B)).

5.12.14 PRESS the PANEL RESET PB-2 push-button (located on the SAFETY CLASS CONTROL CABINET (A))

5.12.15 VERIFY the TRIP/CKT FUNCTIONAL GREEN indicating light (located on the SAFETY CLASS CONTROL CABINET (B)) is illuminated.

DOME PRESSURE TEST

NOTE - This section will only be performed at Tanks requiring a dome pressure transmitter.

5.12.16 NOTYFY Shift Manager that Tank Pressure Transmitter will be out of service.

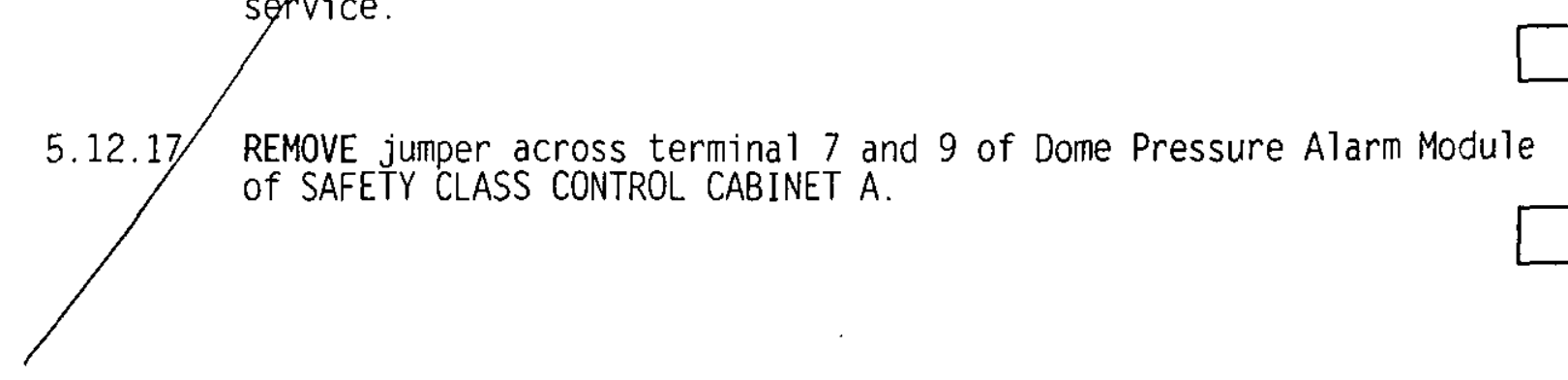




\subsection{SHUTDOWN CIRCUITRY CHECK (Cont.)} 5.12.18 PRESS the PANEL RESET PB-2 push-button (located on the SAFETY CLASS
CONTROL. CABINET $(A)$ ).

5.12.19 ENSURE the TRIP CKT FUNCTIONAL GREEN indicating light (located on the SAFETY CLASS CONTROL. CABINET (B)) is illuminated.

5.12.20 VERIFY WST-PT-6001 Dome Pressure Transmitter is energized.

5.12.21 VALVE OUT WST-PT-6001 and ISOLATE from tank space.

5.12.22 CONNECT a manometer to the WST-PT-6001 Dóme Pressure transmitter. Gauge.

5.12.24 RECORD the manometer reading when the shutdown circuit TRIPS.

\begin{tabular}{|c|c|}
\hline $\begin{array}{c}\text { MANOMETER READING } \\
\text { (Inches Water } \\
\text { Gauge) }\end{array}$ & \\
\hline
\end{tabular}

5.12.25 VERIFY the shutdown circuit trips within a range of 1.4 to 1.6 incres Water Gauge.

5.12.26 VERIFY that from the time that SALW-PSHL-821* trips, to the time tr:at PMP-1-1 and PMP-2-1 OPEN, is LESS THAN 10 seconds.

5.12.27 VERIEX the TRIP CKT FUNCTIONAL GREEN indicating light (located on tre SAFETY CLASS CONTROL CABINET (B)) is NOT illuminated.

\begin{tabular}{|c|c|c|c|c|}
\hline Typo: & Docinent No. & ReyMod & Relens of bits. & poge: \\
\hline REFERENOE. & OTP-200-004 & $A \cdot 16$ & $8 / 23 / 99$ & \%8. of 108 \\
\hline
\end{tabular}




\subsection{SHUTDOWN CIRCUITRY CHECK (Cont.)}

5.12.28 VERIFY that the HT-1-1 contactor (located in cabinet "SAFETY CLASS HEAT TRACE CONTACTOR HT-1") is OPEN.

5.12.29 VERIFY that the PMP $-1-1$ contactor (located in cabinet "SAFETY CLASS PUMP CONTACTOR PMP-1") is OPEN.

5.12.30 VERIFY that the HT-2-1 contactor (located in cabinet "SAFETY CLASS HEAT TRACE CONTACTOR HT-2") is OPEN.

5.12.31 VERIFY that the PMP-2-1 contactor, (1ocated in cabinet "SAFETY CLASS PUMP CONTACTOR PMP-2") is OPEN.

5.12.32 VERIFY that the Data Table Access Module displays "DOME PRESSURE HIGH" (ALARM \#28).

5.12.33 VERIFY that the Operatof Control Station displays "DOME PRESSURE HIGH".

5.12.34 ACKNOWLEDGE the/Operator Control Station and Data Table Access Module alarm condition.

5.12.35 VERIFY that the Jet Pump is not able to be re-started.

5.12.36 SET WST-PT-6001 Dome Pressure manometer to 0 inches Water Gauge.

5.12.3 PRESS the PANEL RESET PB-2 push-button (located on the SAFETY C.ASS CONTROL CABINET $(A))$.

\begin{tabular}{|c|c|c|c|c|}
\hline TPP REFERENEE. & Docinent No. & Rey/lod 16 & Rerops? pars: $8 / 23 / 99$ & 79 of 108 \\
\hline
\end{tabular}




\subsection{SHUTDOWN CIRCUITRY CHECK (Cont.)}

5.12.38 VERIFY the TRIP CKT FUNCTIONAL GREEN indicating light (located on the SAFETY CLASS CONTROL CABINET $(B)$ ) is illuminated.

5.12.39 VERIFY that the Jet Pump heat trace contactors (located at the Safe:y Shutdown Circuit) are CLOSED.

5.12.40 RE-START the Jet Pump at the Data Table Access/Module.

5.12.41 SET WST-PT-6001 Dome Pressure manometer to -3.5 inches water Gauge.

5.12.42 VERIFY the TRIP CKT FUNCTIONAL GREEN indicating light (located on tre SAFETY CLASS CONTROL CABINEN $(\beta))$ is illuminated.

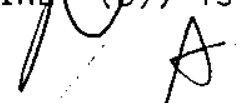

5.12.43 VERIFY that the Jet Pump heat trace contactors (located at the Safe-y Shutdown (ircuit) are CLOSED.

5.12.44 VERIFY that the Jef Pump run light is ON.

5.12.45 VERIFY that the Data Table Access Module displays "DOME PRESSURE LO." (ALARM \#29)

5.12.46 VERIFY/that the Operator Control Station displays "DOME PRESSURE LOW"
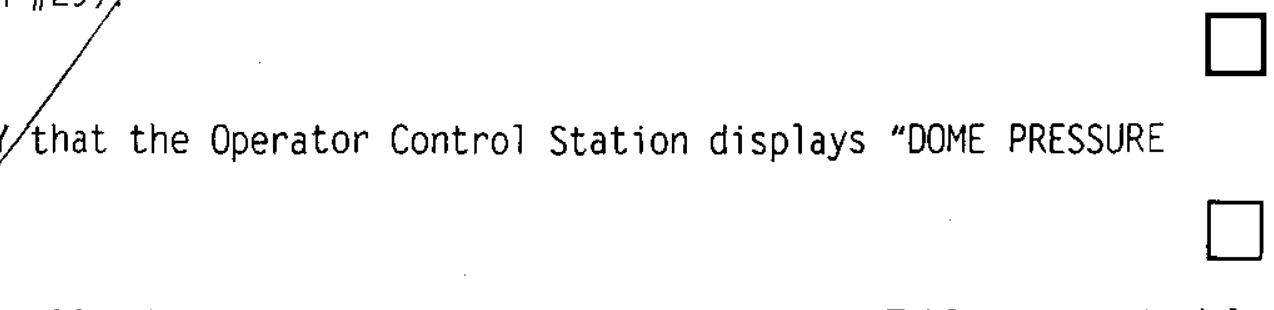

5.12.47 ACKNOWLEDGE the Operator Control Station and Data Table Access roduis alarm condition. 


\subsection{SHUTDOWN CIRCUITRY CHECK (Cont.)}

5.12.48 SET WST-PT-6001 Dome Pressure manometer to 0 inches Water Gauge.

5.12.49 DISCONNECT the manometer from the WST-PT-6001 Dome Pressure transmitter.

5.12.50 VALVE WST-PT-6001 back to service.

5.12.51 DE-ENERGIZE the WST-PT-6001* Dome Pressure transmitter.

5.12.52 VERIFY the TRIP CXT FUNCTIONAL GREEN indicating light (located on the SAFETY CLASS CONTROL CABINET (B)) is/NOT i i luminated.

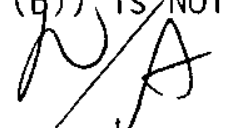

5.12.53 VERIFY that the HT-1-1 contactor ( Pocated in cabinet "SAFETY C:ASS HEAT TRACE CONTACTOR HT-1") is OPEN.

5.12.54 VERIFY that the PMP-1-1 contactor (located in cabinet "SAFETY CLASS PUMP CONTACTOR PMP-1"'J is OPEN.

5.12.55 VERIFY that the HT-2-1 contactor (located in cabinet "SAFETY CL $-\mathrm{SS}$ HEAT TRACE CONTACTOR HT-2") is OPEN.

5.12.56 VERIFY/that the PMP-2-1 contactor (located in cabinet "SAFETY CLASS PUMP CONTACTOR PMP-2") is OPEN.

5.12.57 VERIFY that the Data Table Access Module displays "DOME PRESSUF 三 FAIL" (Alarm \#24).

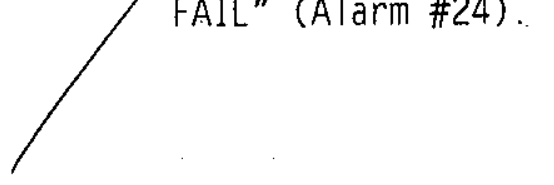




\subsection{SHUTDOWN CIRCUITRY CHECK (Cont.)}

5.12.58 VERIFY that the Operator Control Station displays "DOME PRESSURE' FAIL".

5.12.59 ACKNOWLEOGE the Operator Control Station and Data Table Access Module alarm condition.

5.12.60 VERIFY that the Jet Pump can NOT be re-started/at the Data Table Access Module.

5.12.61 ENERGIZE the WST-PT-6001 Dome Pressure, transmitter.

5.12.62 VERIFY no Data Table Access Modu alarms are present with the EXCEPTION of alarms 12 and 73 confition.

5.12.63 IF they were installed, REMOVE jumpers across FGM-1 and VENT-2 on T31 of SAFETY CLASS CONTROL CABINET (A).

\section{EXHAUSTER INTERFACE}

5.12.64 REQUEST Test Director to VERIFY exhauster interface to the Safe Shutdown Circuit has been installed and that the exhauster Operational/Test Procedure has verified this circuit is Operable.

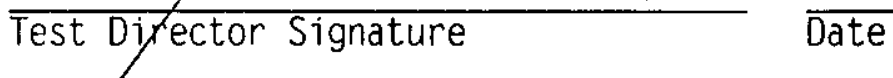

5.12.65 NOTIPY the Tank Monitoring and Control System Operator that the section is about to commence. 5.12.66 IF required, PLACE JUMPER across FGM1-2 and FGM1-1 on TB-1 of SAFETY
CLASS CONTROL CABINET (A).

\begin{tabular}{|c|c|c|c|c|}
\hline TYP? REFERENCE. & 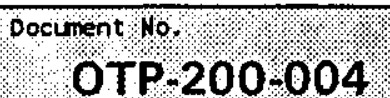 & Revryod 1.16 & fereasforto & 82 of 108 \\
\hline
\end{tabular}




\subsection{SHUTDOWN CIRCUITRY CHECK (Cont.)}

5.12.67 PLACE jumper across terminal 7 and 9 of Dome Pressure Alarm Modul $\theta$.

5.12.68 At the discretion of the Test Director. ENSURE temporary inter iock jumpers. OR software forces are in place for uninstalled equipment.

5.12.69 VERIFY the Safe Shutdown Circuit is reset and ready for/normal operation.

5.12.70 ENSURE exhauster is running per procedure T0-060-085.

5.12.71 START the Jet Pump using the Data Table Access Module.

5.12.72 TRIP the Exhauster.

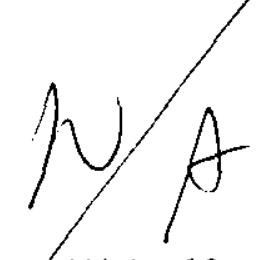

5.12.73 VERIFY the Jet Pump shuts down within 10 seconds after tripping the exhauster.

5.12.74 NOTIFY Tank Monitoring and Control System Operator of exhauster shutdown.

5.12.75 VERIFY the TRIP CXT FUNCTIONAL GREEN indicating light (located on the SAFETY CLASS CONYROL CABINET (B)) is NOT illuminated.

5.12.76 VERIFY that the HT-1-1 contactor (located in cabinet "SAFETY CLFSS HEAT TRACE CONTACTOR HT-1") is OPEN.

5.12.77 VERIFY that the PMP-1-1 contactor (located in cabinet "SAFETY CLASS PUMP CONTACTOR PMP-1") is OPEN.

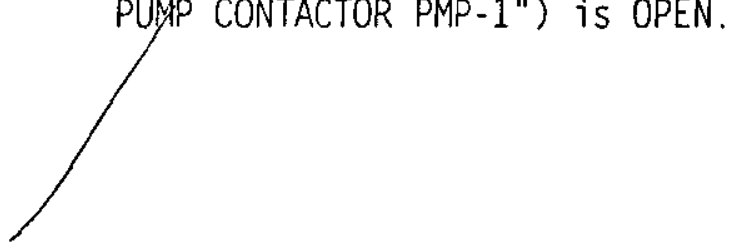

\begin{tabular}{|c|c|c|c|c|}
\hline TYPo REFERENCE & document No. & Rev/4od $/ 1$. & Relesse bate & \\
\hline
\end{tabular}




\subsection{SHUTDOWN CIRCUITRY CHECK (Cont.)}

5.12.78 VERIFY that the HT-2-1 contactor (located in cabinet "SAFETY CLASS HEAT TRACE CONTACTOR HT-2") is OPEN.

5.12.79 VERIFY that the PMP-2-1 contactor (located in cabinet "SAFEYY CLASS PUMP CONTACTOR PMP-2") is OPEN.

5.12.80 VERIFY that the Data Table Access Module displays "SSC TRIP" (Alarm \#18).

5.12.81 VERIFY that the Operator Control Station dísplays "EXHAUSTER SHUTDOWN" AND "SSC TRIP".

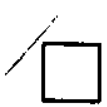

5.12.82 ACKNOWLEDGE the Operator Control St Station and Data Table Access Module alarm condition.

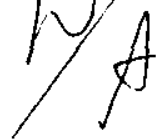

5.12.83 VERIFY that the Jet Pump can NOT be re-started at the Data Table Access Module. 5.12.84 NOTIFY Tank Monitoring and Control System Operator of exhauster
restart.
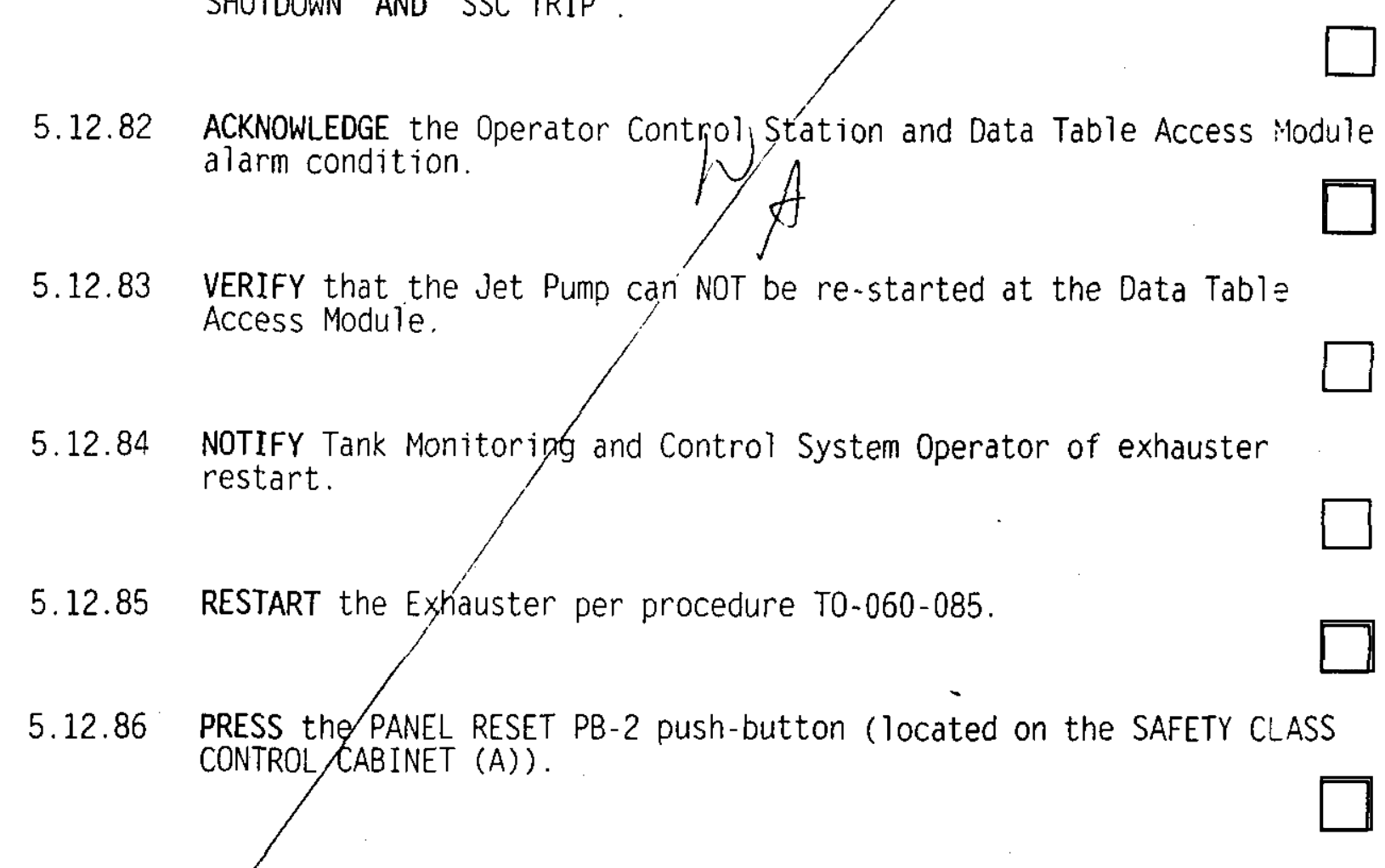

5.12.87 VERIFY the TRIP CKT FUNCTIONAL GREEN indicating light (located on the SAFETY CLASS CONTROL CABINET (B)) is illuminated.

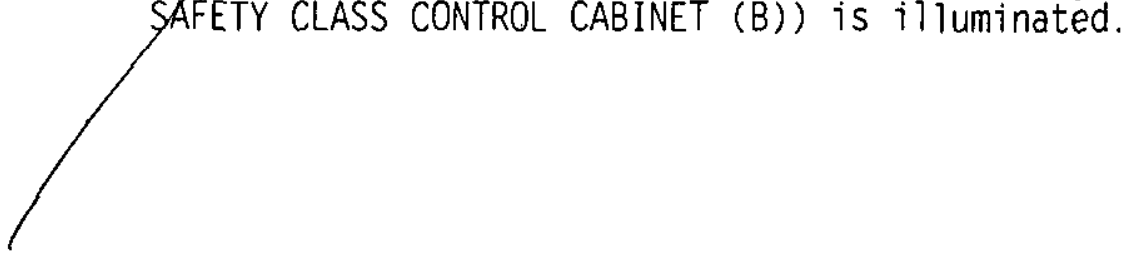

\begin{tabular}{|c|c|c|c|c|}
\hline REFERENGE & $\begin{array}{l}\text { OTP-200-004 } \\
\text { OTP }\end{array}$ & $\begin{array}{c}\text { ReviMod } \\
\text { A-16 }\end{array}$ & 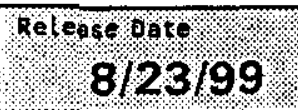 & $\begin{array}{c}\text { Page } \\
84 \text { of } 108\end{array}$ \\
\hline
\end{tabular}




\subsection{SHUTDOWN CIRCUITRY CHECK (Cont.)}

5.12.88 REMOVE jumper acrosS FGM1-1 and FGMI-2 on TB-1.

5.12.89 REMOVE jumper across terminal 7 and 9 of Dome Pressure Alarm Module in SAFETY CLASS CONTROL CABINET (A).

\section{FLAMMABLE GAS MONITOR}

5.12.90 REQUEST Test Director to VERIFY Flammable Gas Monitor interface to the Safe Shutdown Circuit has been installed and that the Flammable Gas Monitor Operational Test Procedure has verified this circuit is Operable.

Test Director Signature Date

5.12.91 PLACE JUMPER acrosS VENT-1 and VENT-2 ON TB-1 Of SAFETY CLASS CONTROL CABINET (A).
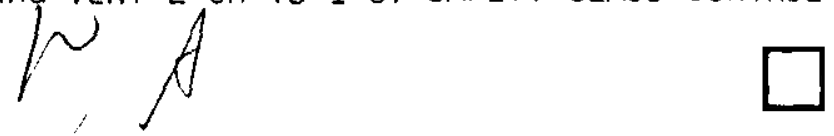

5.12.92 IF required. PLACE jumper across terminal 7 and 9 of Dome Pressure ATarm Module.

5.12.93 ENSURE the Safety Shutdown Circuit is reset and ready for norma? operation.

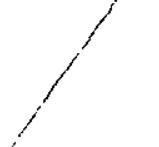

5.12.94 RESTART the Jet Pump using the Data Table Access Module.

5.12.95 INITIATE a Flammable Gas trip in the Flammable Gas Monitor Per Test Director.

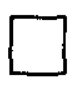

5.12.96 VERIFY the Jet Pump shuts down within 10 seconds after tripping the flammable gas.

5.12.97 VERIFY the TRIP CKT FUNCTIONAL GREEN indicating light (located on tre SAFETY CLASS CONTROL CABINET (B)) is NOT illuminated. 


\subsection{SHUTDOWN CIRCUITRY CHECK (Cont.)}

5.12.98 VERIFY that the HT-1-1 contactor (located in cabinet "SAFETY CLASS HEAT TRACE CONTACTOR HT-1") is OPEN.

5.12.99 VERIFY that the PMP-1-1 contactor (located in cabinet/SSAFETY CLASS PUMP CONTACTOR PMP-1") is OPEN.

5.12.100 VERIFY that the HT-2-1 contactor (located in gabinet "SAFETY CLASS HEAT TRACE CONTACTOR HT-2") is OPEN.

5.12.101 VERIFY that the PMP-2-1 contactor (located in cabinet "SAFETY CLASS PUMP CONTACTOR PMP-2") is OPEN.

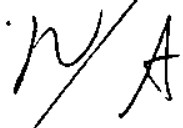

5.12.102 VERIFY that the Data Table Access Module displays "SSC TRIP".

5.12.103 VERIFY that the Operator Control Station displays "FLAMMABLE GAS MONITOR TRIP" AND "SSC IRIP".

5.12.104 VERIFY Jet Pump is/shutdown.

5.12.105 REMOVE jumped across VENT-1 and VENT-2 on TB-1 of SAFETY CLASS CONTROL CABINET (A).

5.12.106 REMOVE JUMPER across terminal 7 and 9 of Dome Pressure Module. if previously installed.

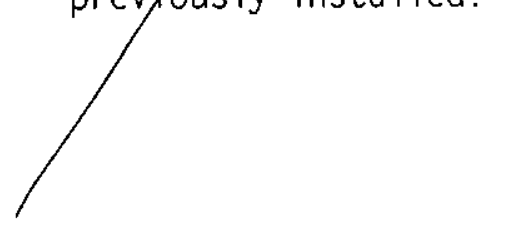


5.12 SHUTDOWN CIRCUITRY CHECK (Cont.)

5.12.107 REMOVE any jumpers or forces NOT required for the pext test section.

5.12.108 Test Director VERIFY that section 5.12 is gomplete by SIGNING below.

5.12.109 Quality Control Inspector VERIFY that section 5.12 is complete by signing below.

$\overline{\text { Quality Control/Inspector Signature }}$


WORKING COL.

Printed on: Sep $24.9912: 52$ pi

5.13 SOFTWARE DOCUMENTATION

5.13.1 REQUEST Engineering to PRINT out a Ladder Logic and Alarm Table for the Pump Instrumentation and Control Skid AND ATTACH it to this procedure.

5.13.2 Test Director YERIEY that section 5.13 is complete by SIGNING below.

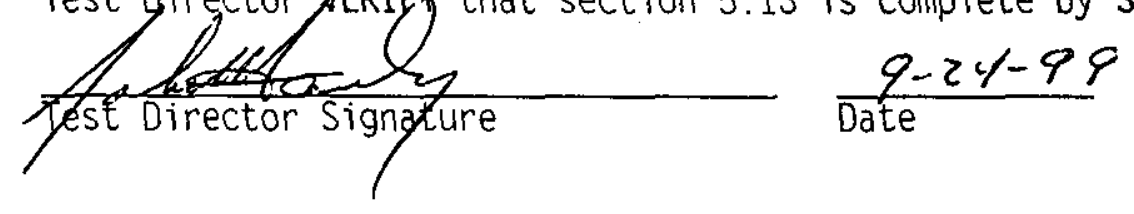

5.13.3 Quality, Control Inspector VERIFY that section 5.13 is complete by signing below. Angliteng

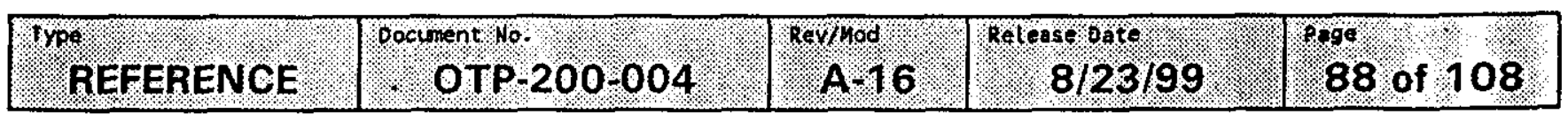

HNF-5820, Rev. 0

A-86

APPENDIX A 


\section{OPERATIONAL TEST PROCEDURE EXCEPTION LOG}

This page may be reproduced as necessary

PAGE of

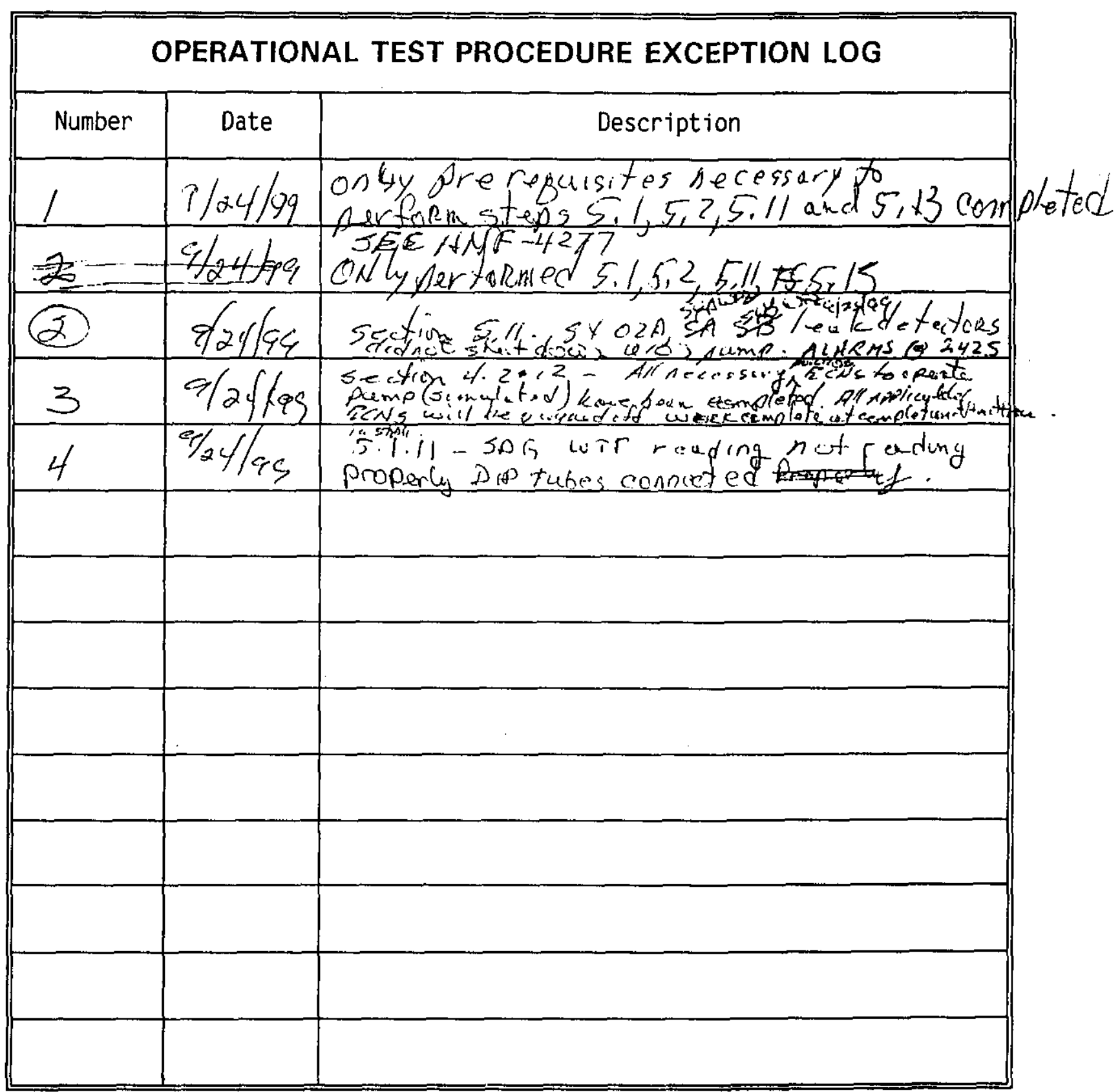

\begin{tabular}{|c|c|c|c|c|}
\hline TyEFERENCE. & Oocument No. OTP-200-004 & Rev/Mod & Release bat? $8 / 23 / 99$ & 89 of 108 \\
\hline
\end{tabular}




\section{OPERATIONAL TEST PROCEDURE EXCEPTION RECORD}

This page may be reproduced as necessary.

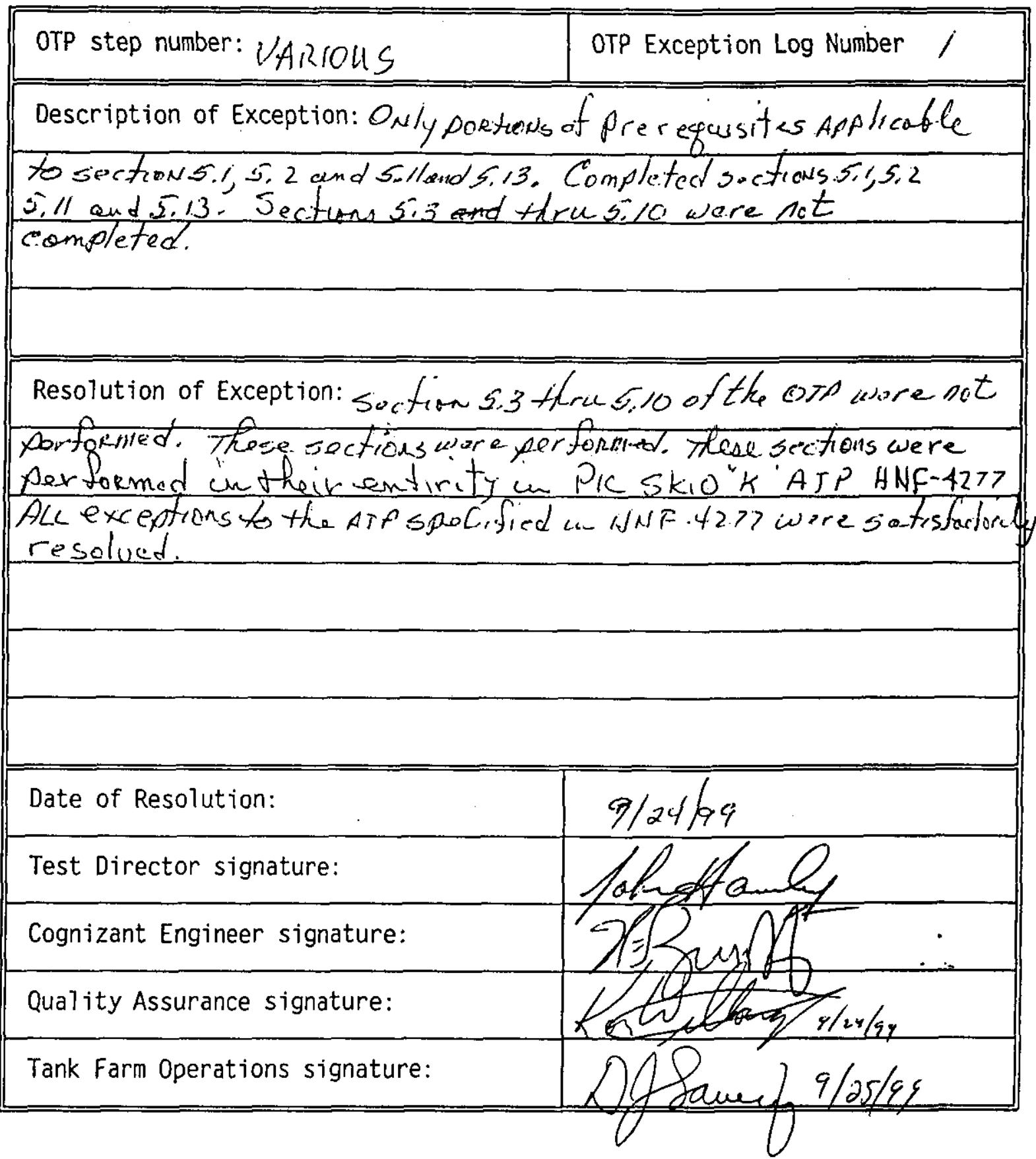

\begin{tabular}{|c|c|c|c|c|}
\hline VYPF & oociunent ro. & Reyrod: 16 & Releast oats 8123199 & 90 of 108 \\
\hline
\end{tabular}




\section{OPERATIONAL TEST PROCEDURE EXCEPTION RECORD}

This page may be reproduced as necessary.

\begin{tabular}{|c|c|}
\hline OTP step number: Sectio 5.11 & OTP Exception Log Number 2 \\
\hline \multirow{2}{*}{\multicolumn{2}{|c|}{ 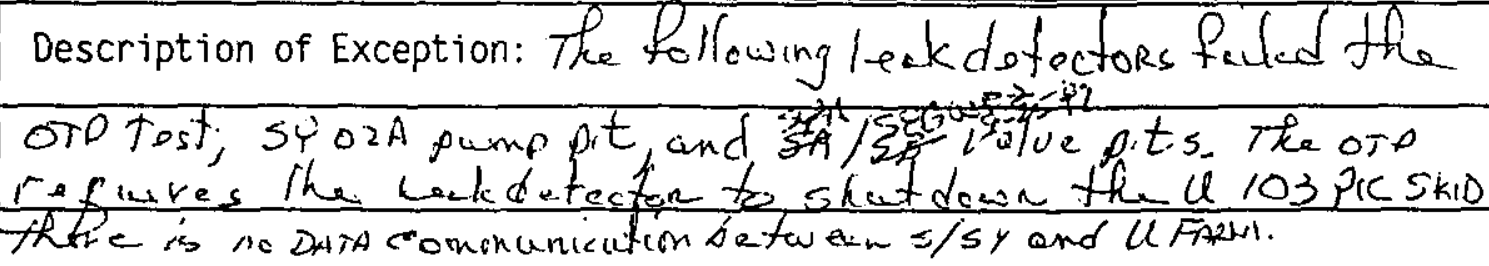 }} \\
\hline & \\
\hline \multicolumn{2}{|c|}{ Resolution of Exception: Accept $A_{5}$ is: The loxk dofector fund (iv) } \\
\hline \multicolumn{2}{|c|}{ 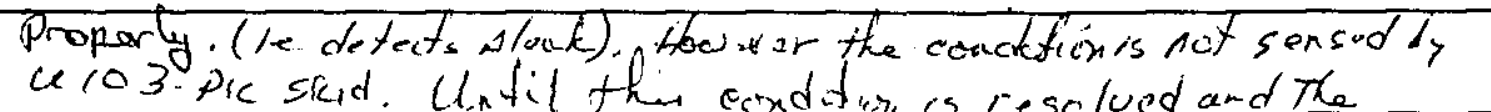 } \\
\hline \multirow{2}{*}{\multicolumn{2}{|c|}{ 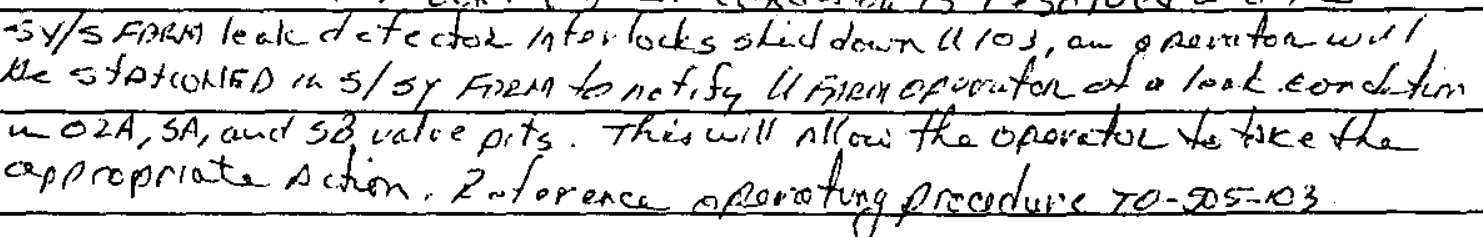 }} \\
\hline & \\
\hline \multicolumn{2}{|l|}{ Date of Resolution: } \\
\hline \multicolumn{2}{|l|}{ Test Director signature: } \\
\hline \multicolumn{2}{|l|}{ Cognizant Engineer signature: } \\
\hline \multicolumn{2}{|l|}{ Quality Assurance signature: } \\
\hline Tank Farm Operations signature: & \\
\hline
\end{tabular}

\begin{tabular}{|c|c|c|c|c|}
\hline REFERENCE & oocinent ${ }^{\text {Ho }}$ OTP-200-004 & Reviluod & release onte, 8123199 & 90 of 108 \\
\hline
\end{tabular}




\section{OPERATIONAL TEST PROCEDURE EXCEPTION RECORD}

This page may be reproduced as necessary.

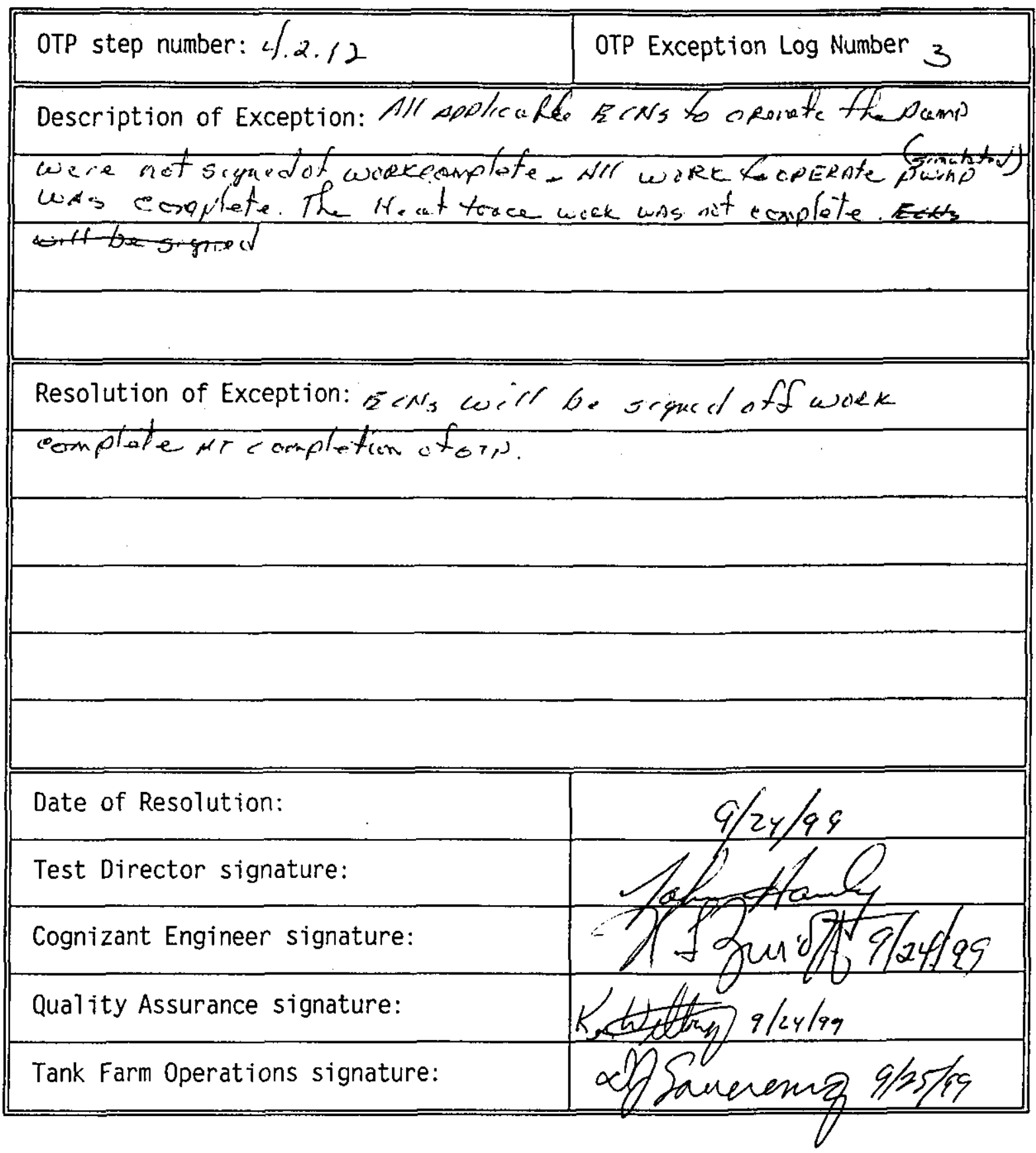

TYpe, ,, Document No.

REFERENCE

OTP. $200-004$

Rev/Mod

A- 16

release pate

$8 / 23 / 99$

ooge:

90 of 108 


\section{OPERATIONAL TEST PROCEDURE EXCEPTION RECORD}

This page may be reproduced as necessary.

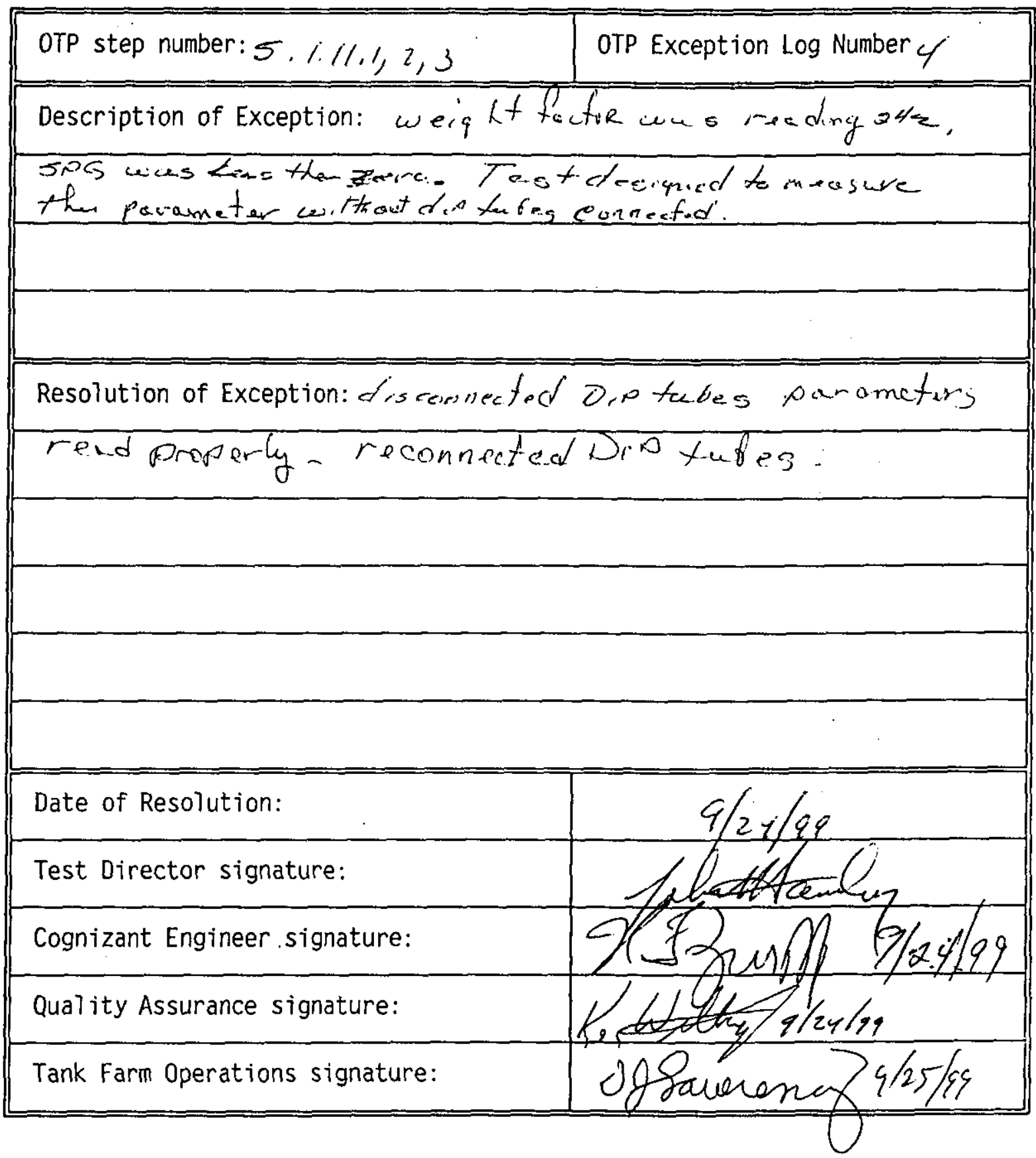




\section{PROCEDURE PERFORMER SIGNATURE SHEET}

All personnel who will be performing, initialing and signing the procedure shall enter their printed name, signature and initials below.

NAME (PRINT)

KENGICcoug hB

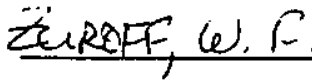

Pawel Garz.

Chad Whition

ILSO $P_{L x_{5}}$

NGUYN TH.

MN Vohns on

DT SAUERESSLG

$M R \quad \mathrm{KOCH}$

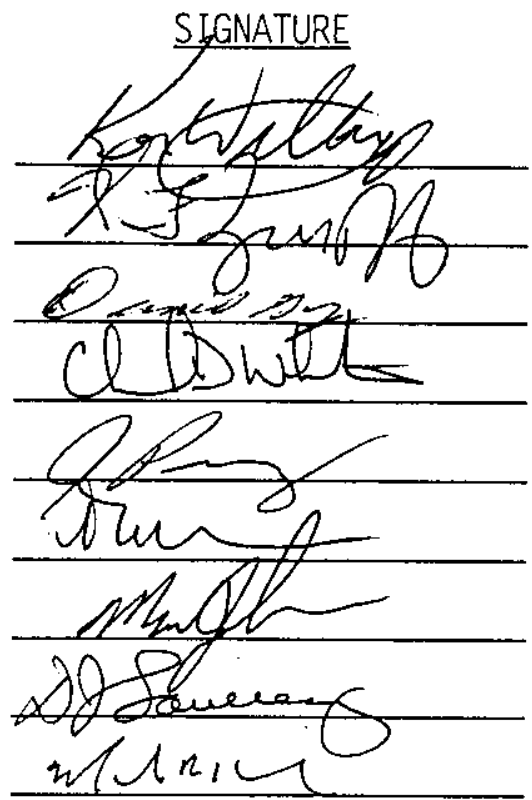

INITIALS
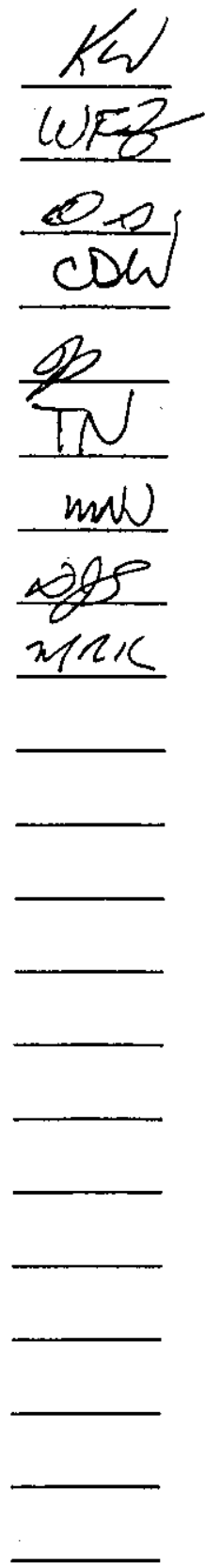

\section{REFERENCE}

$000 \mathrm{ment} 1 \mathrm{so}$

OTP-200-004

Revrhod

A- 15

Telease ort

$5 / 18 / 99$

Poge

91 of 106 
WORKING OOF.

Priru.d on: Sep 24, 99 12:52 pm

OPERATIONAL TEST PROCEDURE ACCEPTANCE RECORD

This Operational Test Procedure has been completed and the results, including redline changes, exceptions, and exception resolutions, have been reviewed for compliance with the intent of the Purpose (Section 1.0). The test results are accepted by the undersigned:

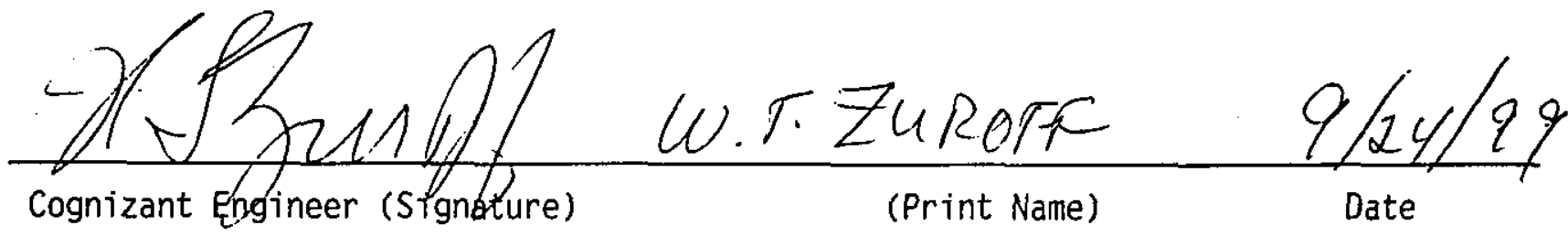

\begin{tabular}{clc}
$W / N h K R$ & $m R$ lock t & $q / 2 . / 99$ \\
\hline Engineering Manager (Signature) & (Print Name) & Date
\end{tabular}
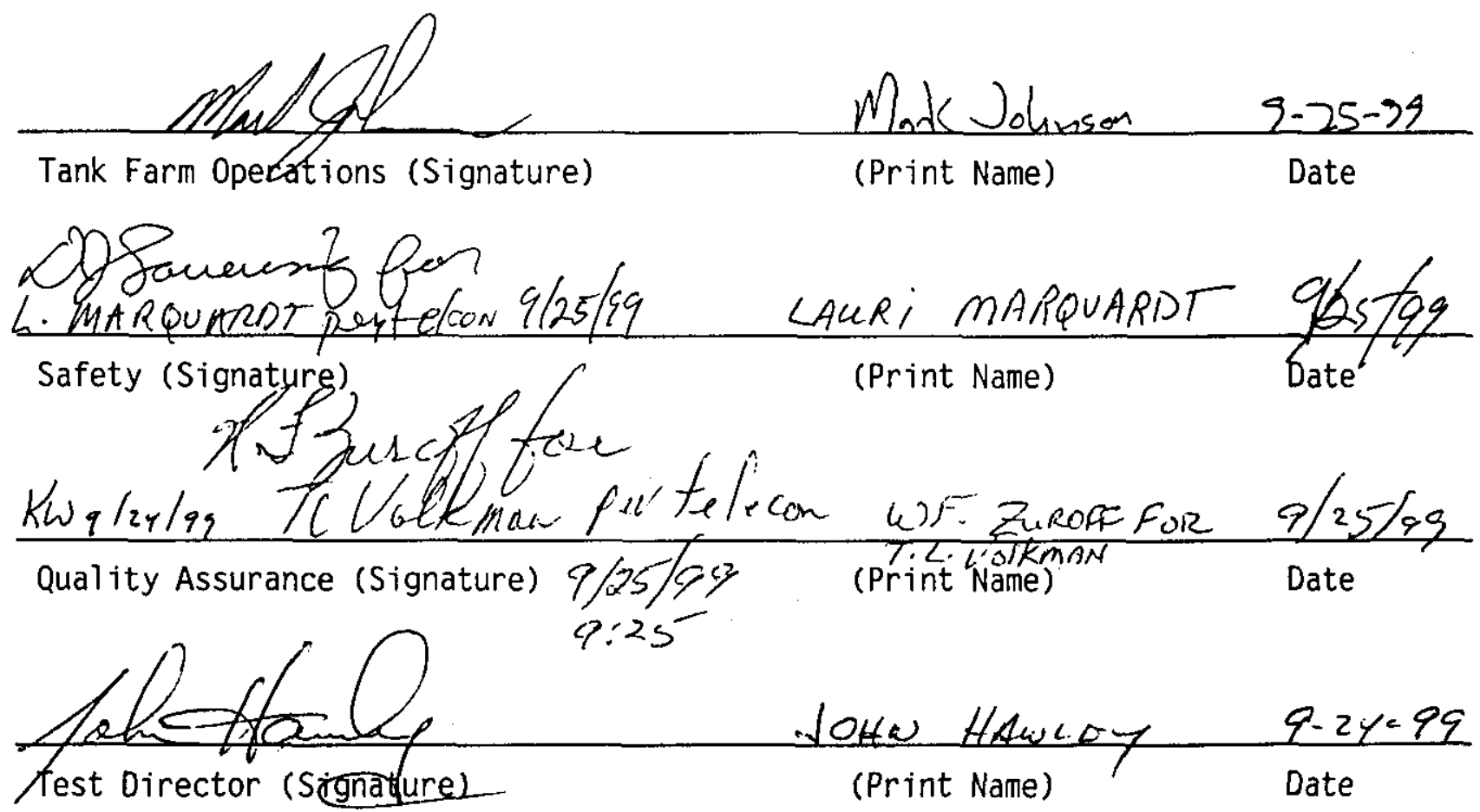

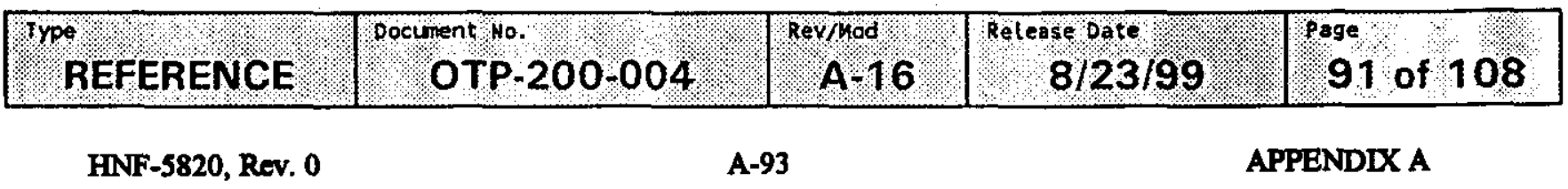




\section{PROCEDURE HISTORY SIGNATURE SHEET}

\begin{tabular}{|l|l||}
\hline PCA Incorporated: WTF-97-113 & MOD \\
Procedure Signatures for OTP-200-004. R1 \\
USQ Screening Number TF-96-0390
\end{tabular}

\begin{tabular}{|c|c|c|c|c|}
\hline YYPo REFERENCE. & $\begin{array}{l}\text { Dociment No. } \\
\text { OTP-200-004 }\end{array}$ & A R. 16 & $\begin{array}{l}\text { Relesse oute } \\
8 / 23 / 99\end{array}$ & 93 of 108 \\
\hline
\end{tabular}




\section{PROCEDURE HISTORY SIGNATURE SHEET (Cont.)}

\begin{tabular}{|c|c|c|c|}
\hline \multirow{2}{*}{\multicolumn{2}{|c|}{$\begin{array}{l}\text { PCA Incorporated: } \\
\text { Procedure Signatures for OTP-200-004. RO } \\
\text { USQ Screening Number }\end{array}$}} & NEW & SQ \\
\hline & & TYPE OF CHANGE & $\begin{array}{c}\text { REVIEW } \\
\text { DESIGNATOR }\end{array}$ \\
\hline POSITION/ORG & DELEGATE & DATE & \\
\hline NPO & D. Dudley & $\underline{4 / 8 / 97}$ & \\
\hline Shift Manager & D. J. Sauressig & $\underline{4 / 7 / 97}$ & \\
\hline QA Engineer & T.J. Volkman & $5 / 22 / 97$ & \\
\hline Safety Engineer & L.S. Krogsrud & 5/20/97 & \\
\hline Rad. Control Eng. & J. Pieper & $\underline{5 / 29 / 97}$ & \\
\hline Cog Engineer & M.R. Koch & $4 / 7 / 97$ & \\
\hline Acceptance Review & D.C. Ashworth & $5 / 29 / 97$ & \\
\hline Approval Authority & D.J. Sauressig & $5 / 28 / 97$ & \\
\hline Pages Affected & Reason for Change & Summary & nange \\
\hline All & Engineering Request & New Pro & \\
\hline
\end{tabular}

Trpe REFERENCE
Document lo.

OTP-200-004
ReYmod

A-16
Reloose 0otse

$8 / 23 / 99$ 


\section{PROCEDURE HISTORY SIGNATURE SHEET (Cont.)}

\begin{tabular}{|c|c|c|c|}
\hline \multirow{2}{*}{\multicolumn{2}{|c|}{$\begin{array}{l}\text { PCA Incorporated: WTF-97-178 } \\
\text { Procedure Signatures for 0TP-200-004. A-2 } \\
\text { USQ Screening Number TF-96-0390 }\end{array}$}} & MOD & $\mathbf{N} / \mathbf{A}$ \\
\hline & & TYPE OF CHANGE & $\begin{array}{c}\text { REVIEW } \\
\text { DESIGNATOR }\end{array}$ \\
\hline POSITION/ORG & DELEGATE & DATE & \\
\hline NPO & S.A. Ham-Huebner & $9 / 10 / 97$ & \\
\hline Eng/Stab & M.R. Koch & $\underline{9 / 10 / 97}$ & \\
\hline Acceptance Review & K.W. Johnson & 9/11/97 & \\
\hline Approval Authority & D.J. Sauressig & $9 / 11 / 97$ & \\
\hline Pages Affected & Reason for Change & Summary & lange \\
\hline 62 & Al low for specific package number entry. & Added wark package entr & \\
\hline
\end{tabular}

PCA Incorporated: WTF-97-184

\section{MOD}

TYPE OF CHANGE

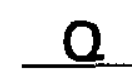

REVIE:I DESIGNATOR

USQ Screening Number TF-96-583

\begin{tabular}{lll} 
POSITION/ORG & DELEGATE & DATE \\
\hline NPO & B.D. Foreman & $\underline{9 / 11 / 97}$ \\
QE/WTFQA & M.C. Tipps & $\underline{9 / 11 / 97}$ \\
Mgr/Stab & D.J. Saueressig & $\underline{9 / 11 / 97}$ \\
Eng/Stab & M.R. Koch & $\underline{9 / 11 / 97}$ \\
Acceptance Review & K.W. Johnson & $\underline{9 / 11 / 97}$ \\
Approval Authority & D.J. Sauressig & $\underline{9 / 11 / 97}$
\end{tabular}

\begin{tabular}{|c|c|c|}
\hline Pages Affected & Reason for Change & Summary of Change \\
\hline $\begin{array}{c}10 \\
12,14 \\
13,61 \\
15 \\
28 \\
29,36 \\
30 \\
31 \\
34,38,42,44,45,48,57,58 \\
61,64,65\end{array}$ & $\begin{array}{l}\text { Clarify for field use. } \\
\text { Issuance of standing Order controls. } \\
\text { Some instruments require functional check } \\
\text { only } \\
\text { Clear alarms received on power up. } \\
\text { Equipment improvement. } \\
\text { Repeat of test in field not necessary or } \\
\text { practicable. } \\
\text { Tests entire loop. } \\
\text { Intrinsic safety changes prompted wiring } \\
\text { changes. } \\
\text { Reviewed orp against final software alarm } \\
\text { messages. Corrected to match. }\end{array}$ & $\begin{array}{l}\text { Specified when test equipment is shop or: } 1 \text { y. } \\
\text { Added FGM and intrinsic safety circuit power. } \\
\text { Changed "CALIBR" to "CAL/FUNCTIONAL CHEC<" } \\
\text { Added alarm acknowledgement on power up. } \\
\text { Allowed for use of new flowmeters. } \\
\text { Qual ify section as shop work only. } \\
\text { Specify FGM test signal at beginning of loop. } \\
\text { Correct thermocouple labels. } \\
\text { Correct wording, punctuation, and spelling of } \\
\text { alarm windows, and ordering of alarms. }\end{array}$ \\
\hline
\end{tabular}

\begin{tabular}{|c|c|c|c|c|}
\hline Type RFEF & bocument Ho & Reyirod & Reterse oate & Poge 95 of 108 \\
\hline
\end{tabular}


PROCEDURE HISTORY SIGNATURE SHEET (Cont.)

\begin{tabular}{|c|c|c|c|}
\hline \multicolumn{2}{|c|}{ PCA Incorporated: WTF-97-186 } & MOD & $\mathbf{N} / \mathbf{A}$ \\
\hline \multicolumn{2}{|c|}{$\begin{array}{l}\text { Procedure Signatures for 0TP-200-004. A-3 } \\
\text { USQ Screening Number TF-96-583 }\end{array}$} & TYPE OF CHANGE & $\begin{array}{c}\text { REVIEW } \\
\text { DESIGNATOR }\end{array}$ \\
\hline POSITION/ORG & DELEGATE & DATE & \\
\hline NPO/Stab & B. Foreman & $9 / 15 / 97$ & \\
\hline SOM/WTFO & Del Scott & $9 / 16 / 97$ & \\
\hline Eng/Stab & I.H. Nquyen & $9 / 15 / 97$ & \\
\hline Eng/Stab & M.R. Koch & $9 / 15 / 97$ & \\
\hline Acceptance Review & K.W. Johnson & $9 / 17 / 97$ & \\
\hline Approval Authority & D.J. Sauressig & $9 / 15 / 97$ & \\
\hline Pages Affected & Reason for Change & Summary & lange \\
\hline $\begin{array}{l}12(4.2 .7) \\
18(5.1 .10 .1) \\
20(5.2 .3-5.2 .5) \\
30(5.3 .49)\end{array}$ & $\begin{array}{l}\text { Ensure closed configuration at start of } \\
\text { oTP. } \\
\text { Correct to match field. } \\
\text { Regulator fluctuates with flow and may } \\
\text { need to be readjusted. } \\
\text { Changed to match field. }\end{array}$ & $\begin{array}{l}\text { Added valves to checkli } \\
\text { Change Lr to WFT. } \\
\text { Changed order of steps. } \\
\text { be readjusted after flo } \\
\text { Corrected terminal numb }\end{array}$ & $\begin{array}{l}\text { Wh regulator to } \\
\text { ablished. }\end{array}$ \\
\hline
\end{tabular}

PCA Incorporated: WTF-97-188

Procedure Signatures for OTP-200-004. A-3

USQ Screening Number TF-96-583

POSITION/ORG DELEGATE DATE

\begin{tabular}{||lll} 
NPO/Stab & B. Foreman & $\underline{9 / 16 / 97}$ \\
Eng/Stab & $\underline{\text { I.H. Nquyen }}$ & $\underline{9 / 16 / 97}$ \\
Eng/Stab & M.R. Koch & $\underline{9 / 16 / 97}$ \\
Acceptance Review & K.W. Johnson & $\underline{9 / 17 / 97}$ \\
Approval Authority & D.J. Sauressig & $\underline{9 / 16 / 97}$ \\
\hline
\end{tabular}

\begin{tabular}{|l|l|l|}
\hline \hline Pages Affected & \multicolumn{1}{|c|}{ Reason for Change } & \multicolumn{1}{|c|}{ Summary of Change } \\
\hline $25(5.3 .21-22)$ & $\begin{array}{l}\text { Allows for field configuration } \\
\text { Conditions. } \\
\text { Allows for field configuration } \\
\text { conditions. } \\
\text { Clarified step. }\end{array}$ & $\begin{array}{l}\text { Added ENSURE valve positions for instrument } \\
\text { transmitters. } \\
\text { Added ENSURE valve positions for instrument } \\
\text { transmitters. } \\
\text { Added remove FGM leads. }\end{array}$ \\
\hline $30(5.3 .49)$ &
\end{tabular}

\begin{tabular}{|c|c|c|c|c|}
\hline Typo & oocument No. & Revinod & Release pate & Page \\
\hline REFERENCE. & OTP-200-004 & A. 16 & $8 / 23 / 99$ & 96 of 108 \\
\hline
\end{tabular}




\section{PROCEDURE HISTORY SIGNATURE SHEET (Cont.)}

\begin{tabular}{|c|c|c|c|}
\hline \multicolumn{2}{|c|}{ PCA Incorporated: WTF-97-189 } & MOD & $\mathbf{N} / \mathbf{A}$ \\
\hline \multicolumn{2}{|c|}{$\begin{array}{l}\text { Procedure Signatures for 0TP-200-004. A-4 } \\
\text { USQ Screening Number TF-96-0583 }\end{array}$} & TYPE OF CHANGE & $\begin{array}{l}\text { REVIEW } \\
\text { DESIGNATOR }\end{array}$ \\
\hline POSITION/ORG & DELEGATE & DATE & \\
\hline NPO/Stab & B.A. Foreman & $9 / 17 / 97$ & \\
\hline Eng/Stab & I.H. Nquyen & 9/17/97 & \\
\hline SOM/WTF & M. Garret & $9 / 17 / 97$ & \\
\hline Acceptance Review & K.W. Johnson & $9 / 19 / 97$ & \\
\hline Approval Authority & D.J. Sauressig & $9 / 18 / 97$ & \\
\hline Pages Affected & Reason for Change & Summary & lange \\
\hline $\begin{array}{l}41,45 \\
43 \\
46 \\
54 \\
60\end{array}$ & $\begin{array}{l}\text { Setpoint must be passed to witness change } \\
\text { on Dov. } \\
\text { Allowed to exit section correctly. } \\
\text { Added clarity. } \\
\text { Generic procedure; correct for use on all } \\
\text { skids. } \\
\text { Consistency with LD tests. }\end{array}$ & $\begin{array}{l}\text { Change 6" to 7". } \\
\text { Added step to shut off } \\
\text { Added tolerance. } \\
\text { Remove "A" } \\
\text { Change cal ibration to }\end{array}$ & onal check. \\
\hline
\end{tabular}

\begin{tabular}{|c|c|c|c|c|}
\hline " REFERENCE & dooment & Rev/4od & Relense pate & Page 97 of 108 \\
\hline
\end{tabular}




\section{PROCEDURE HISTORY SIGNATURE SHEET (Cont.)}

\begin{tabular}{|c|c|c|}
\hline \multicolumn{3}{|c|}{$\begin{array}{l}\text { Current Modification: A-5 } \\
\text { USQ Screening Number: TF-96-583 } \\
\text { Approva1 Designator: SQ } \\
\text { PCA Incorporated: WTF-98-0123 }\end{array}$} \\
\hline POSITION/ORG & DELEGATE & DATE \\
\hline NPO/STAB & B.D. Foreman & $4 / 17 / 98$ \\
\hline QAE/SST & M.C. Tipps & $4 / 20 / 98$ \\
\hline Safety/SST & L.S. Krogsrud & $4 / 20 / 98$ \\
\hline SOM/WTF & D.W. Strasser & $4 / 20 / 98$ \\
\hline Cognizant Engineer & M.R. Koch & $4 / 20 / 98$ \\
\hline Acceptance Review & X.W. Johnson & $4 / 22 / 98$ \\
\hline Approval Authority & D. Scott & $4 / 21 / 98$ \\
\hline \multicolumn{3}{|c|}{$\begin{array}{l}\text { Justification: Updated requirements and references. Made clarifications and corrected } \\
\text { omissions. }\end{array}$} \\
\hline \multicolumn{3}{|c|}{ 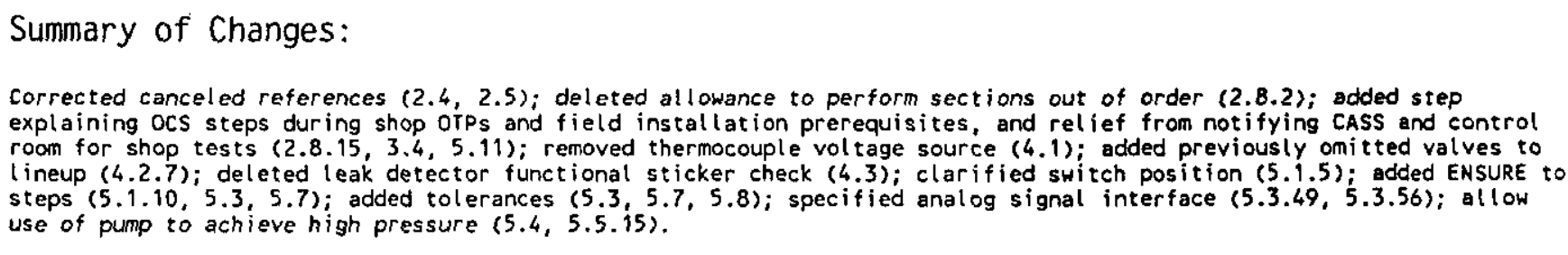 } \\
\hline
\end{tabular}

Current Modification: A-5

USQ Screening Number: TF -96-583

Approval Designator: SQ

PCA Incorporated: WTF-98-0123

Justification: Updated requirements and references. Made clarifications and corrected

Corrected canceled references (2.4, 2.5); deleted allowance to perform sections out of order (2.8.2); added step explaining OCS steps during shop OTPs and field installation prerequisites, and relief from notifying CASS and control

for shop tests $(2.8 .15,3,4,5.11)$; removed thermocouple voltage source (4.1): added previously omitted valves to

steps $(5,1,10,5.35,7)$ added tolerances $(5,3,5.7,5.8)$; specified analog signal interface (5.3.49.5.3.56): allow

use of pump to achieve high pressure $(5.4,5.5 .15)$.

\begin{tabular}{|c|c|c|c|c|}
\hline Rypo & Dociment fo: & Rexpod & $\begin{array}{c}\text { Release date } \\
8 / 23 / 99\end{array}$ & 98 of 108 \\
\hline
\end{tabular}




\section{PROCEDURE HISTORY SIGNATURE SHEET (Cont.)}

\begin{tabular}{|c|c|c|}
\hline \multicolumn{3}{|c|}{$\begin{array}{l}\text { Last Full Revision: R0 } \\
\text { Release Date: } 5 / 29 / 97 \\
\text { USQ Screening Number: } \\
\text { Approval Designator: SQ }\end{array}$} \\
\hline \multicolumn{3}{|c|}{$\begin{array}{l}\text { Current Modification: A-6 } \\
\text { USQ Screening Number: TF-96-583 Rev } 3 \\
\text { Approval Designator: SQ } \\
\text { PCA Incorporated: WTF-98-0125 }\end{array}$} \\
\hline POSITION/ORG & DELEGATE & DATE \\
\hline NPO & S. Ham-Huebner & $4 / 24 / 98$ \\
\hline $\mathrm{QAE} / \mathrm{SST}$ & M.C. Tipps & $4 / 24 / 98$ \\
\hline Safety & D. Abramson & $4 / 24 / 98$ \\
\hline Team Lead/Stab & M. Johnson & $4 / 23 / 98$ \\
\hline Cognizant Engineer & $\frac{\text { M.R. Koch }}{\text { T. Nquyen }}$ & $\frac{4 / 23 / 98}{4 / 23 / 98}$ \\
\hline Acceptance Review & K.W. Johnson & $4 / 27 / 98$ \\
\hline Approval Authority & K.J. Freeman & $4 / 24 / 98$ \\
\hline \multicolumn{3}{|c|}{$\begin{array}{l}\text { Justification: Corrections for typographical errors and equipment } \\
\text { modifications. }\end{array}$} \\
\hline $\begin{array}{l}\text { Summary of Changes: } \\
\text { changed "filed" to "field" } \\
\text { indicator to calibration ve }\end{array}$ & $\begin{array}{l}\text { ragraph } 2.8 .12) \text {; adde } \\
\text { ication table (4.3); }\end{array}$ & $\begin{array}{l}\text { ineup }(\text { step } 4.2 .7) ; \text { added pressure } \\
\text { ve number }(5.1 .10 .3)\end{array}$ \\
\hline
\end{tabular}

DATE

$4 / 24 / 98$

$4 / 24 / 98$

$4 / 24 / 98$

$4 / 23 / 98$

$4 / 24 / 98$ 


\section{PROCEDURE HISTORY SIGNATURE SHEET (Cont.)}

\begin{tabular}{|c|c|c|}
\hline \multicolumn{3}{|c|}{$\begin{array}{l}\text { Last Full Revision: R0 } \\
\text { Release Date: } 5 / 29 / 97 \\
\text { USQ Screening Number: } \\
\text { Approval Designator: SQ }\end{array}$} \\
\hline \multicolumn{3}{|c|}{$\begin{array}{l}\text { Current Modification: A-7 } \\
\text { USQ Screening Number: TF-98-0836 } \\
\text { Approval Designator: SQ } \\
\text { PCA Incorporated: WTF-98-0207 }\end{array}$} \\
\hline POSITION/ORG & DELEGATE & DATE \\
\hline NPO & B.D. Foreman & $\underline{8 / 20 / 98}$ \\
\hline $\mathrm{QAE} / \mathrm{SST}$ & M.C. Tipps & $\underline{8 / 20 / 98}$ \\
\hline Safety & L.S. Krogsrud & $\underline{8 / 20 / 98}$ \\
\hline Stab. Mgr & D.J. Saueressig & $\underline{8 / 20 / 98}$ \\
\hline Cognizant Engineer & W.F. Zuroff & $8 / 20 / 98$ \\
\hline Acceptance Review & M.F. Wahl & $8 / 22 / 98$ \\
\hline Approval Authority & D.J. Saueressig & $8 / 20 / 98$ \\
\hline \multicolumn{3}{|c|}{ Justification: Engineering and Operations request. } \\
\hline \multicolumn{3}{|c|}{ 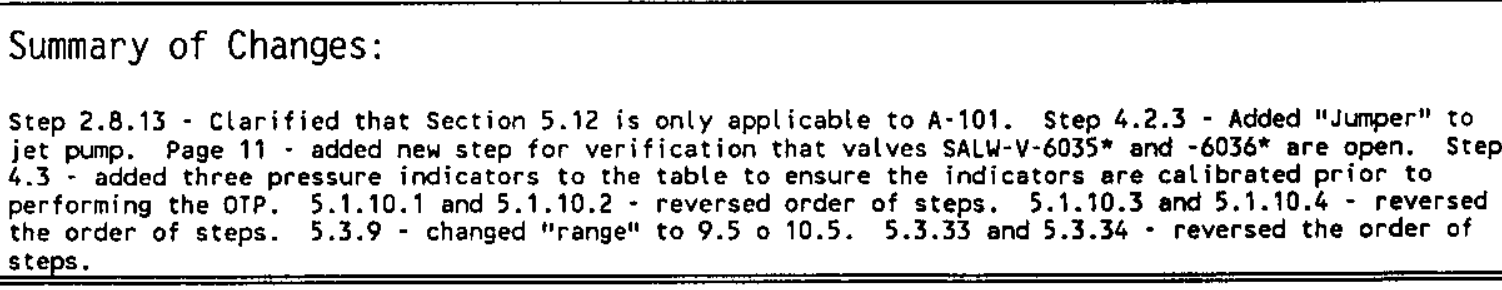 } \\
\hline
\end{tabular}

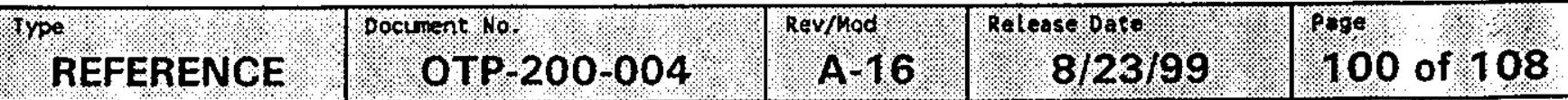




\section{PROCEDURE HISTORY SIGNATURE SHEET (Cont.)}

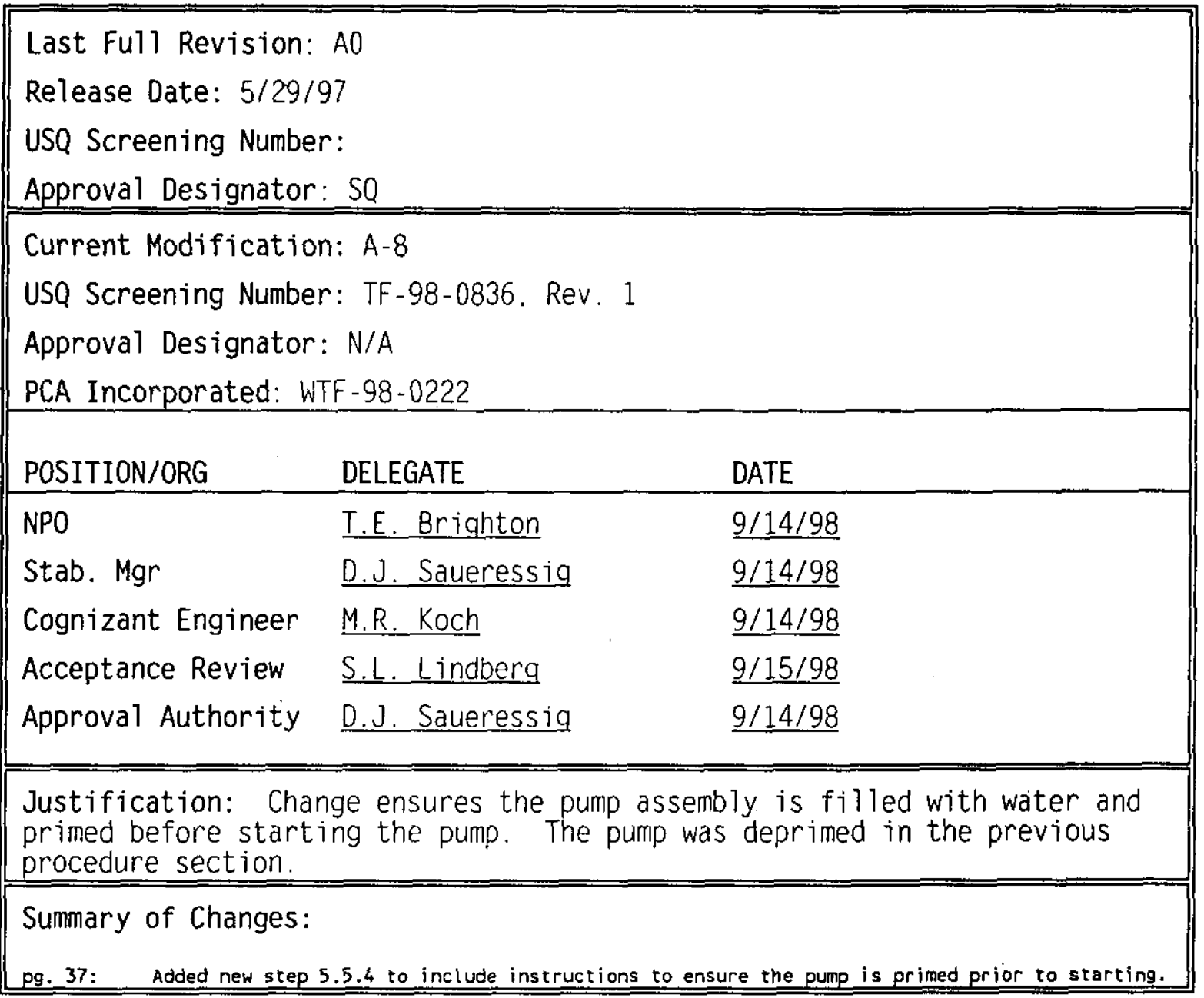

\begin{tabular}{|c|c|c|c|c|}
\hline REFERENCE & bocunent No. & Rev/Mod & Relepst Oote $8 / 23 / 99$ & 101 of 108 \\
\hline
\end{tabular}




\section{PROCEDURE HISTORY SIGNATURE SHEET (Cont.)}

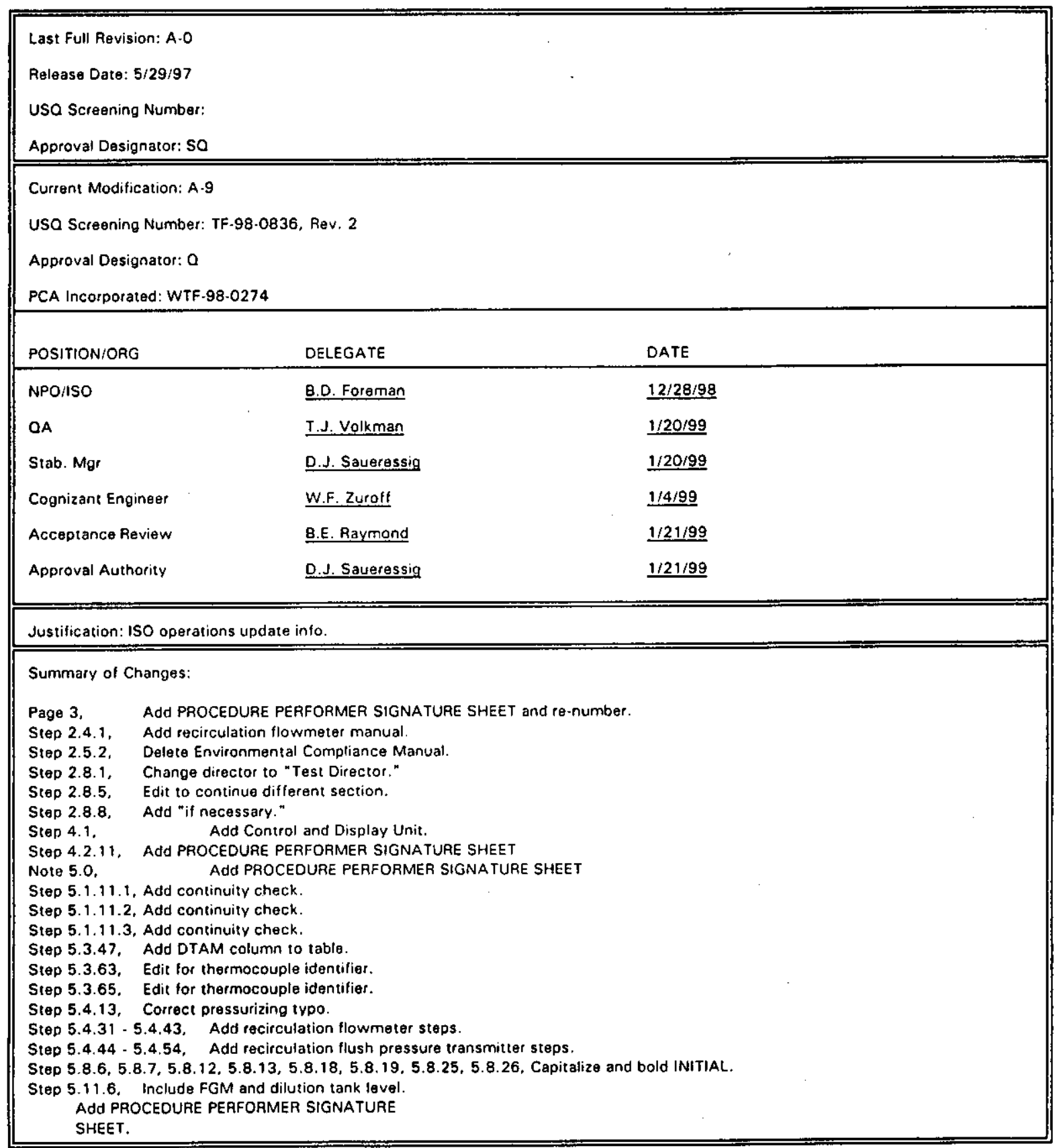

\begin{tabular}{|c|c|c|c|c|}
\hline$p e$ & Dochent No & Rev//40 & Relonse Date & 8996 \\
\hline REFERENCE & OTP-200-004 & A-16 & $8 / 23 / 99$ & 102 of 108 \\
\hline
\end{tabular}




\section{PROCEDURE HISTORY SIGNATURE SHEET (Cont.)}

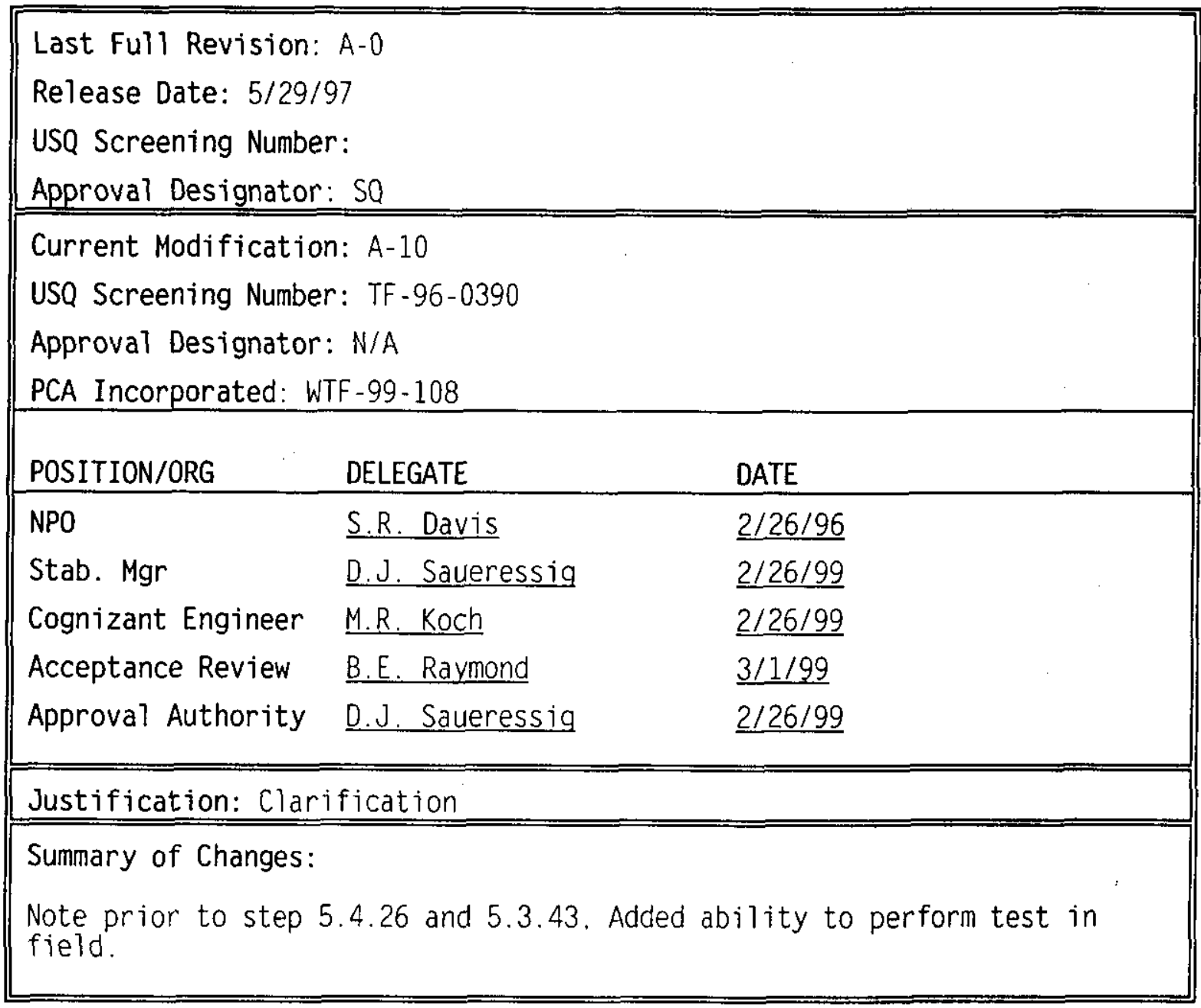




\section{PROCEDURE HISTORY SIGNATURE SHEET (Cont.)}

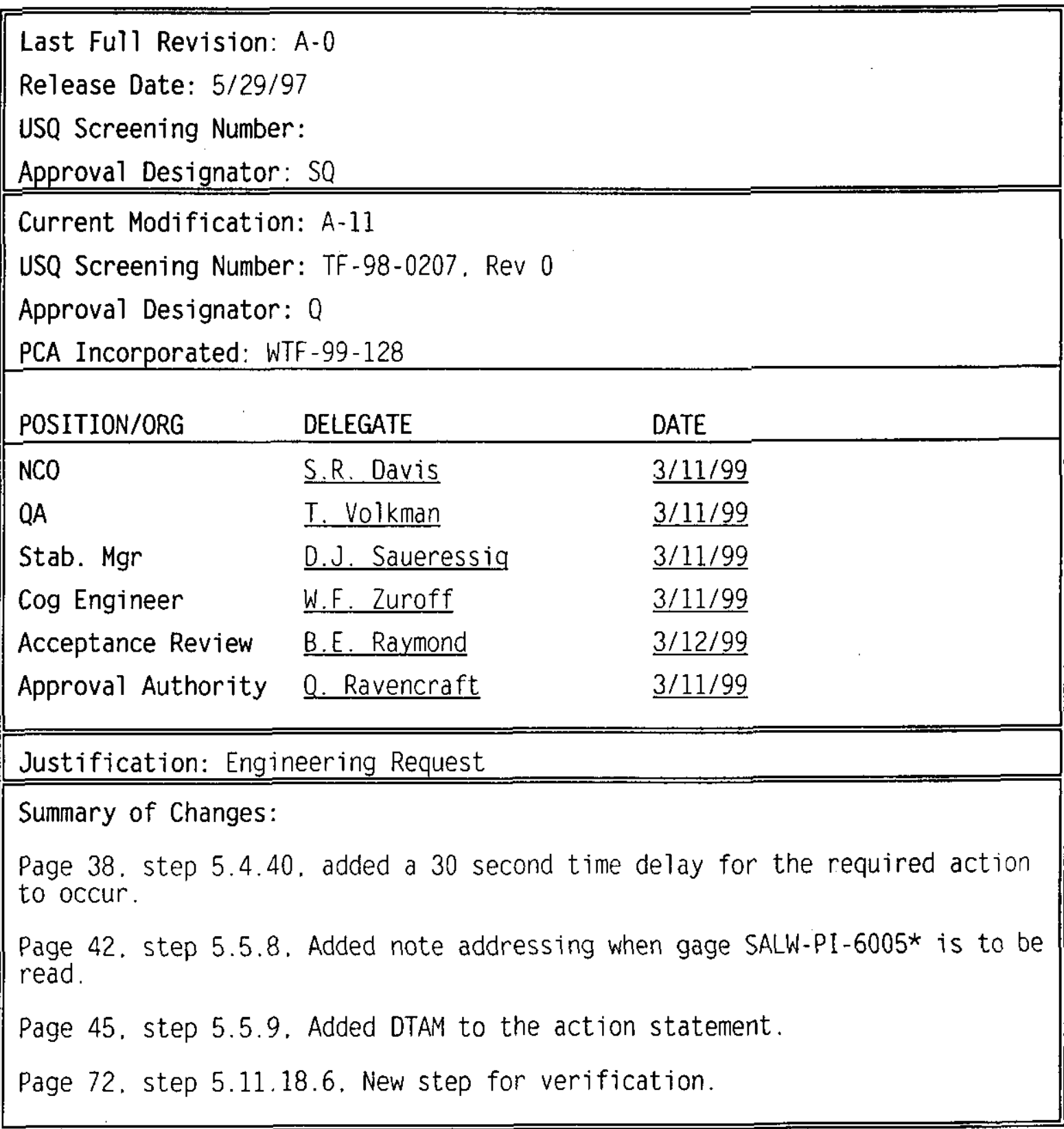




\section{PROCEDURE HISTORY SIGNATURE SHEET (Cont.)}

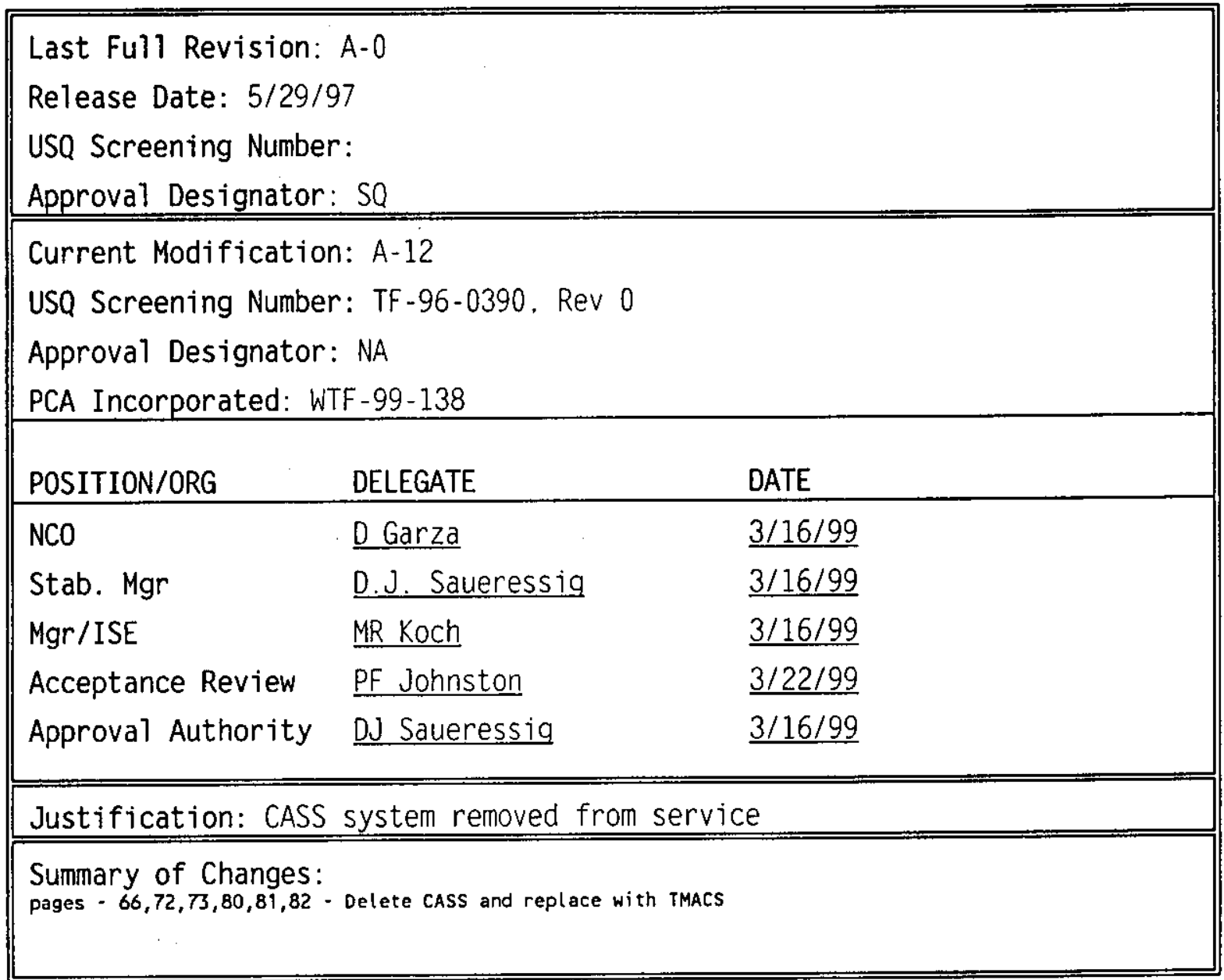




\section{PROCEDURE HISTORY SIGNATURE SHEET (Cont.)}

\begin{tabular}{|c|c|c|}
\hline \multicolumn{3}{|c|}{$\begin{array}{l}\text { Last Full Revision: A-0 } \\
\text { Release Date: } 5 / 29 / 97 \\
\text { USQ Screening Number: } \\
\text { Approval Designator: SQ }\end{array}$} \\
\hline \multicolumn{3}{|c|}{$\begin{array}{l}\text { Current Modification: A-13 } \\
\text { USQ Screening Number: TF-98-0836. Rev } 3 \\
\text { Approval Designator: SQ } \\
\text { PCA Incorporated: WTF-99-198 }\end{array}$} \\
\hline POSITION/ORG & DELEGATE & DATE \\
\hline NCO/IS & I.E. Brighton & $4 / 20 / 99$ \\
\hline$Q A$ & T.J. Volkman & $4 / 20 / 99$ \\
\hline ENGRII/SAFETY & M. Omar Jaka & $4 / 20 / 99$ \\
\hline Stab. Mgr & D.J. Saueressig & $4 / 21 / 99$ \\
\hline CogEng/ISE & W.F. Zuroff & $4 / 21 / 99$ \\
\hline Acceptance Review & S.E. Bevans & $4 / 21 / 99$ \\
\hline Approval Authority & DJ Saueressig & $\underline{4 / 21 / 99}$ \\
\hline \multicolumn{3}{|c|}{ Justification: Update for model 4.46 FGMS and dome space FGM } \\
\hline \multicolumn{3}{|c|}{$\begin{array}{l}\text { Summary of Changes: } \\
\text { page } 31 \text { - Edit title and steps to include model } 4.46 \text { and clarify pit FGMs } \\
\text { page } 32 \text { - Add new page for dome space installed FGMs, steps } 5.3 .57 \text { through } 5.3 .64\end{array}$} \\
\hline
\end{tabular}

\begin{tabular}{|c|c|c|c|c|}
\hline Re REFRENCE. & Document No. OTP-200-004 & Rev/Mod: 16 & Releaso bato & 19.96 of 108 \\
\hline
\end{tabular}




\section{PROCEDURE HISTORY SIGNATURE SHEET (Cont.)}

\begin{tabular}{|c|c|c|}
\hline \multicolumn{3}{|c|}{$\begin{array}{l}\text { Last Ful1 Revision: A-0 } \\
\text { Release Date: } 5 / 29 / 97 \\
\text { USQ Screening Number: } \\
\text { Approval Designator: SQ }\end{array}$} \\
\hline \multicolumn{3}{|c|}{$\begin{array}{l}\text { Current Modification: A-14 } \\
\text { USQ Screening Number: TF-98-1201, Rev } 1 \\
\text { Approval Designator: NA } \\
\text { PCA Incorporated: WTF-99-0218 }\end{array}$} \\
\hline POSITION/ORG & DELEGATE & DATE \\
\hline NCO/IS & I.E. Brighton & $\underline{05 / 07 / 99}$ \\
\hline Stab. Mgr & D.J. Saueressig & $\underline{05 / 07 / 99}$ \\
\hline CogEng/ISE & W.F. Zuroff & $\underline{05 / 07 / 99}$ \\
\hline Acceptance Review & S.E. Bevans & $\underline{05 / 07 / 99}$ \\
\hline Approval Authority & DJ Saueressig & $05 / 07 / 99$ \\
\hline \multicolumn{3}{|c|}{ Justification: Engineering request, incorporate PS-2 chan } \\
\hline
\end{tabular}




\section{PROCEDURE HISTORY SIGNATURE SHEET (Cont.)}

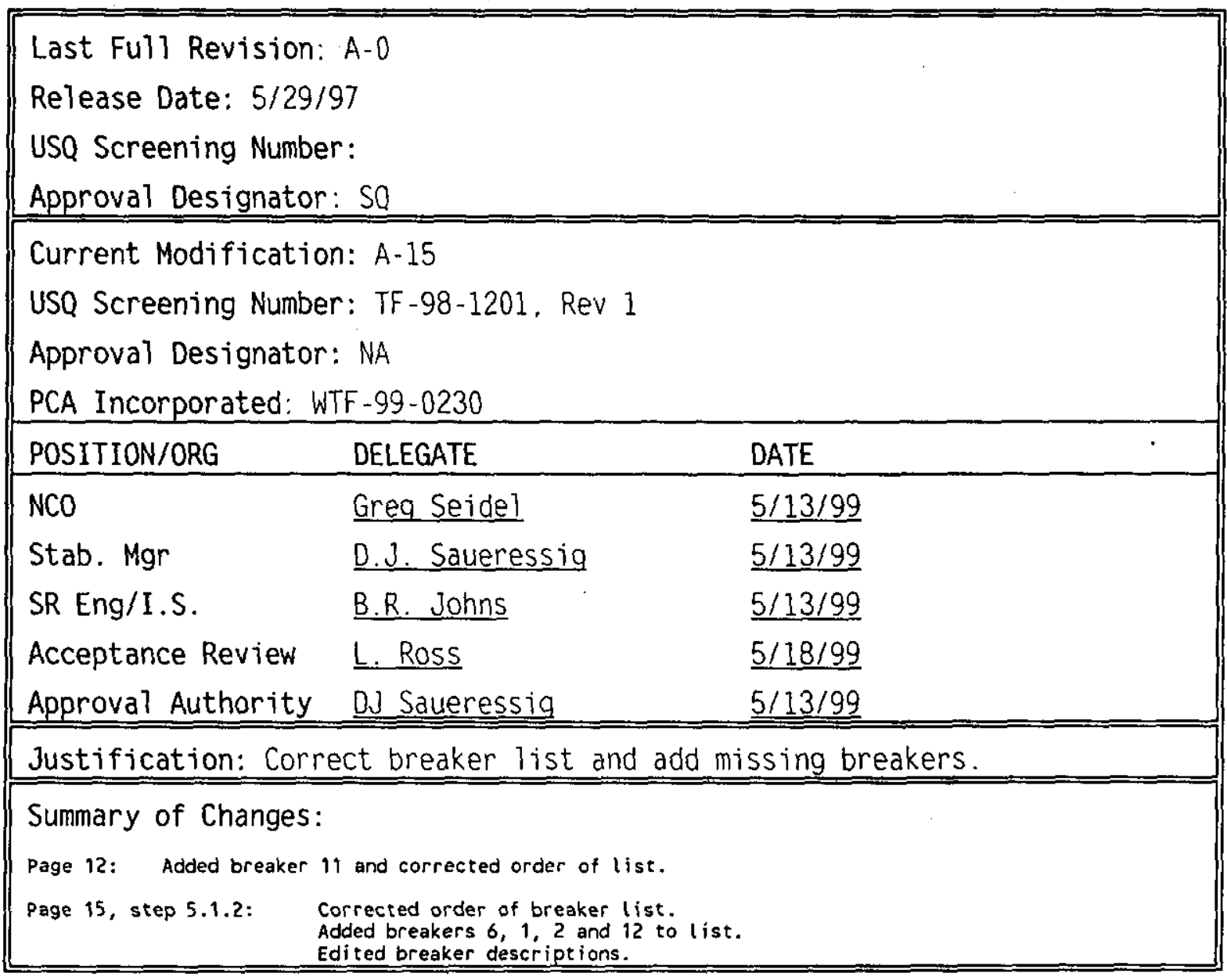


LAD 2 - Total Rungs in File $=18$

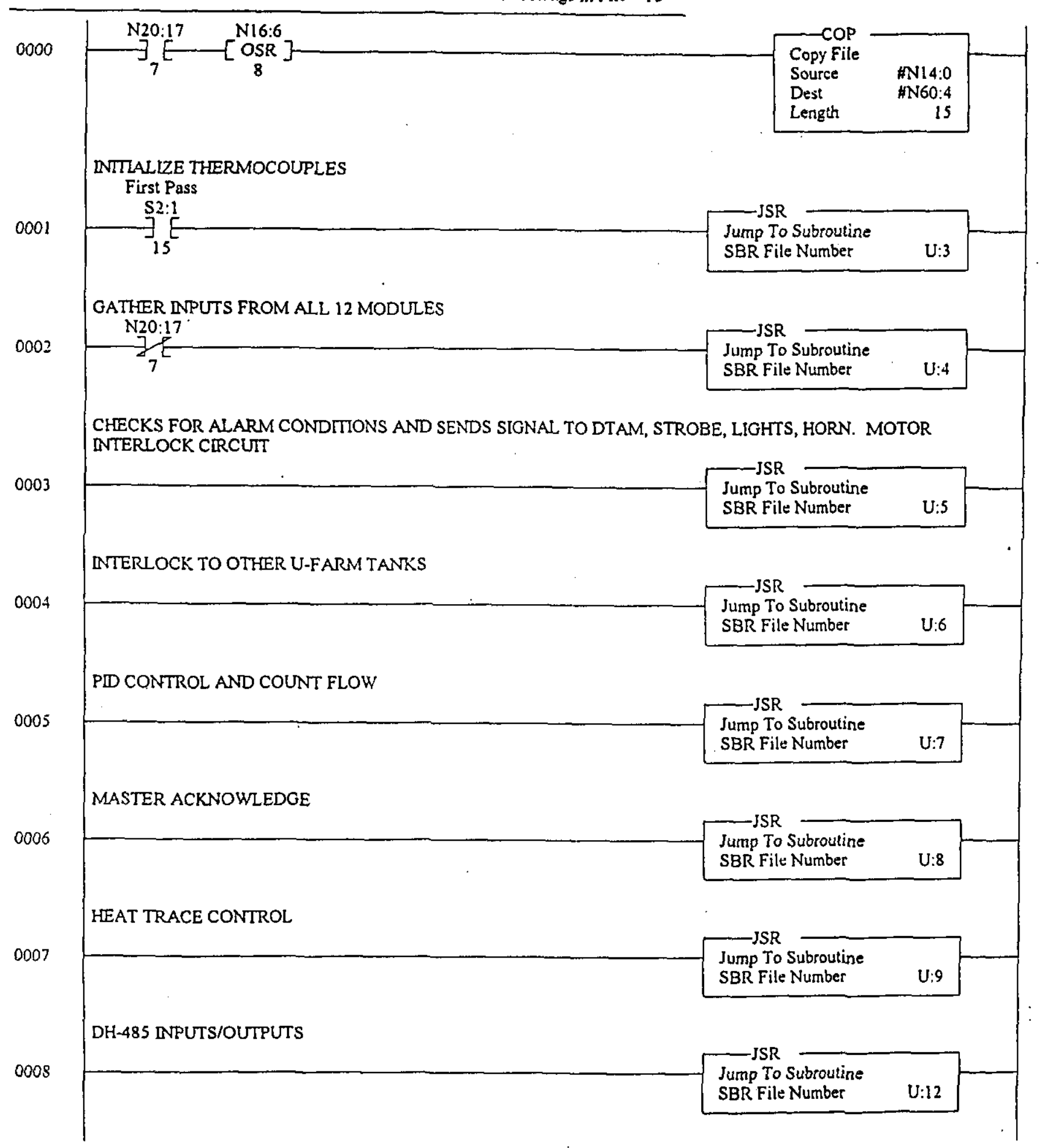


LAD 2 - - Total Rungs in File $=18$

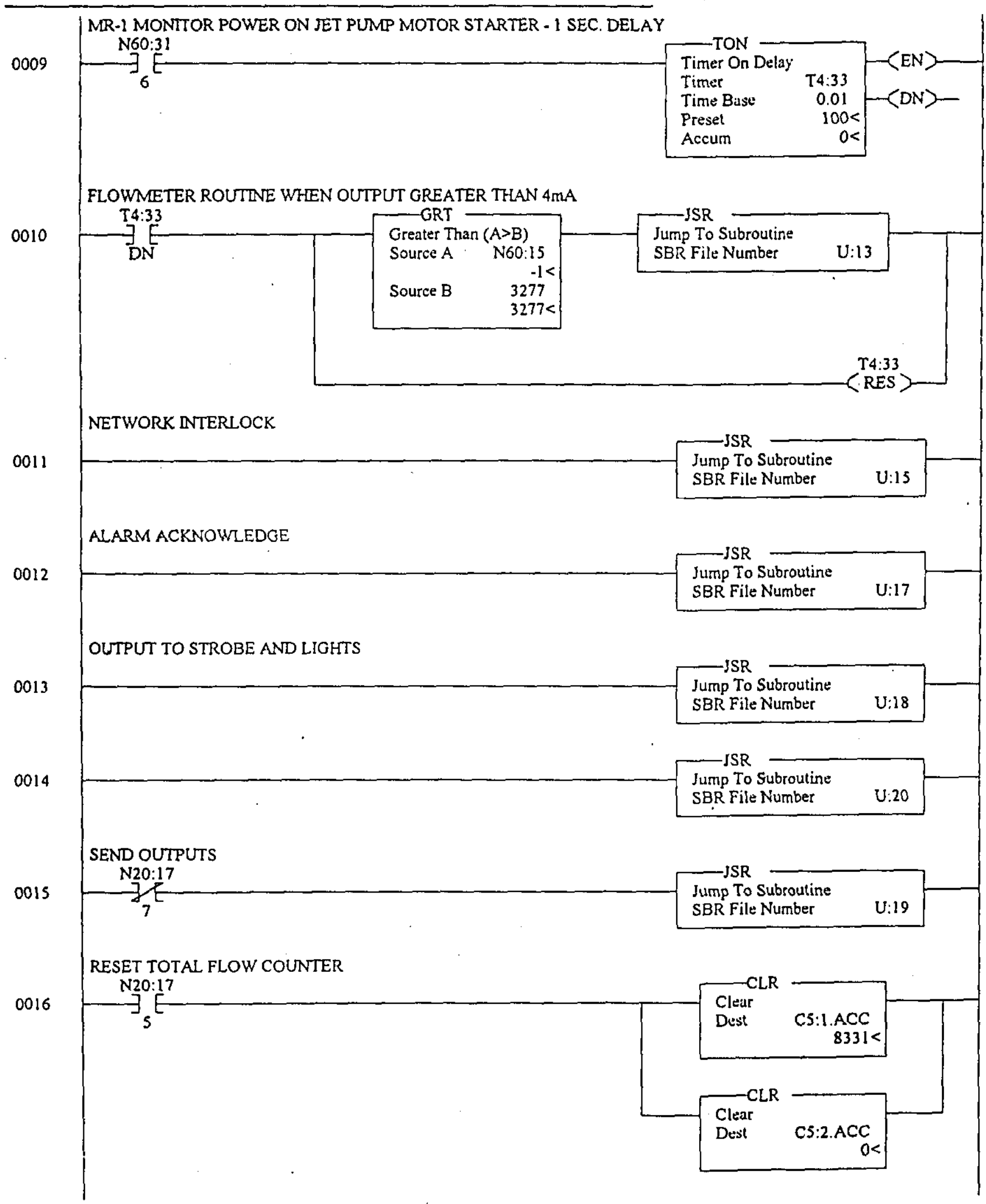

Page $1 \cdot 2$

Monduy, September 27, $1999.08: 16: 12$ 
LAD 2.- Total Rungs in File $=18$

$0017 \stackrel{2}{1}<\mathrm{END}\rangle-$


LAD $3-$ Total Rungs in File $=16$

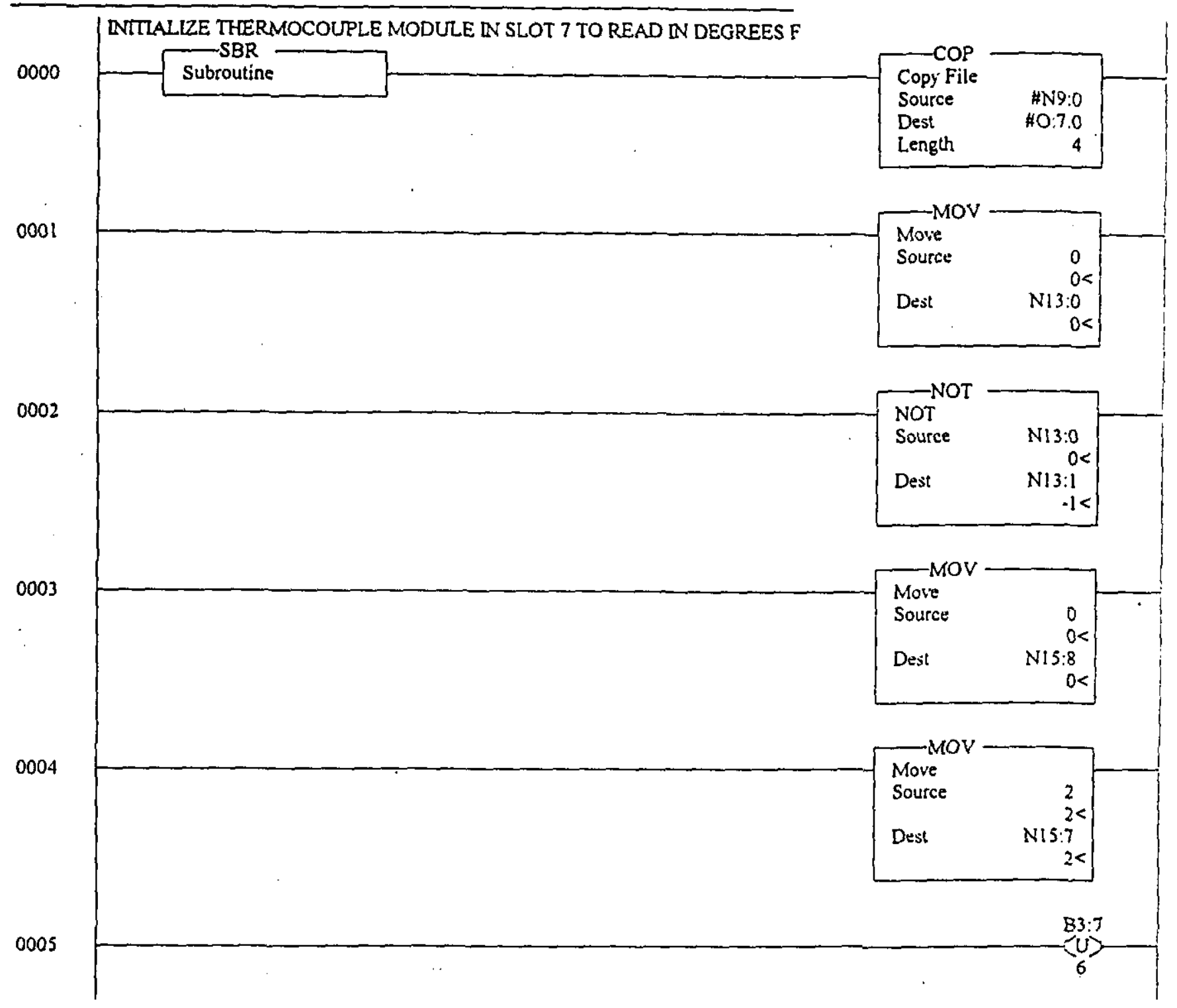




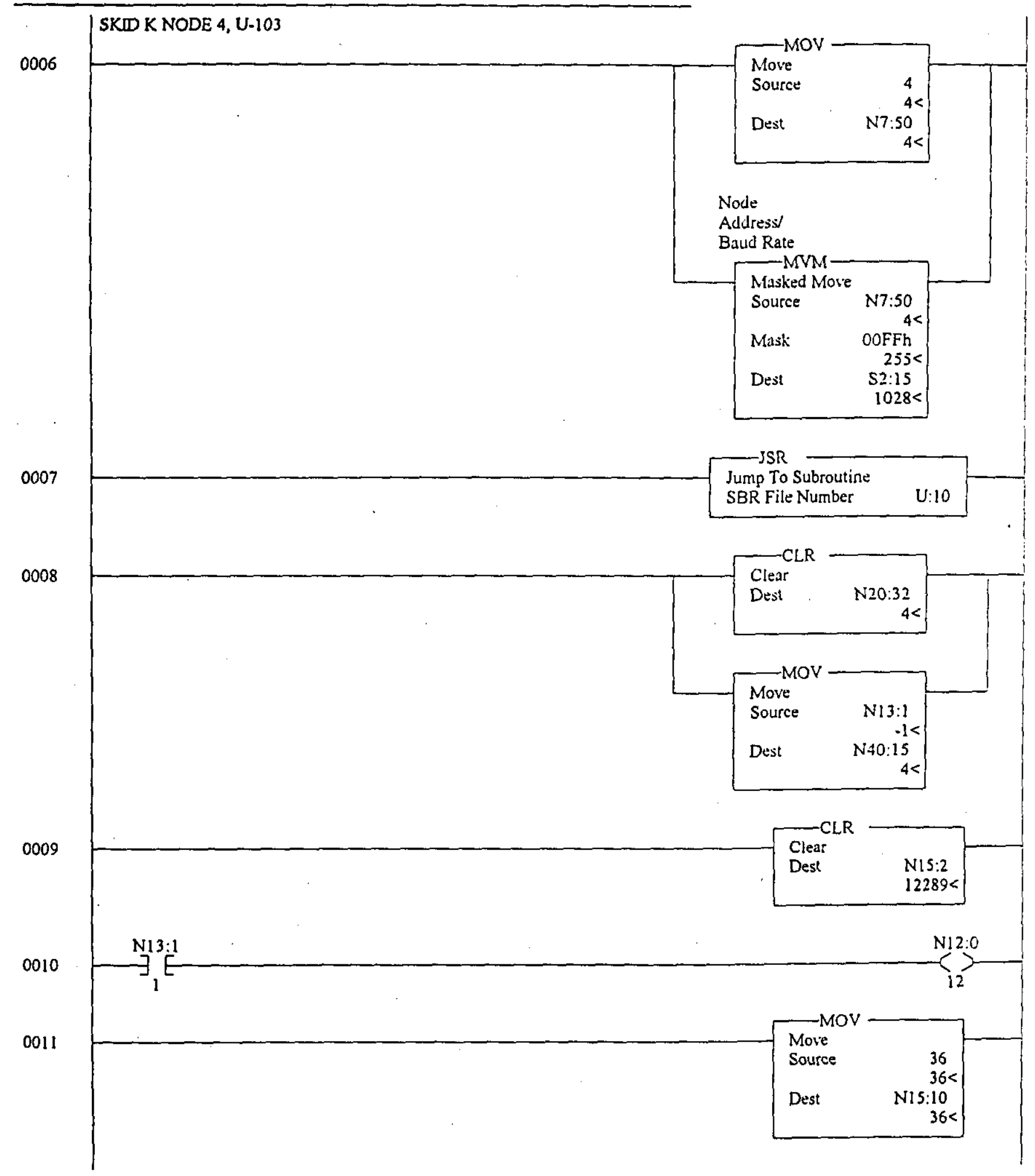

Page 1 - 2 
LAD 3 - . Total Rungs in File $=16$

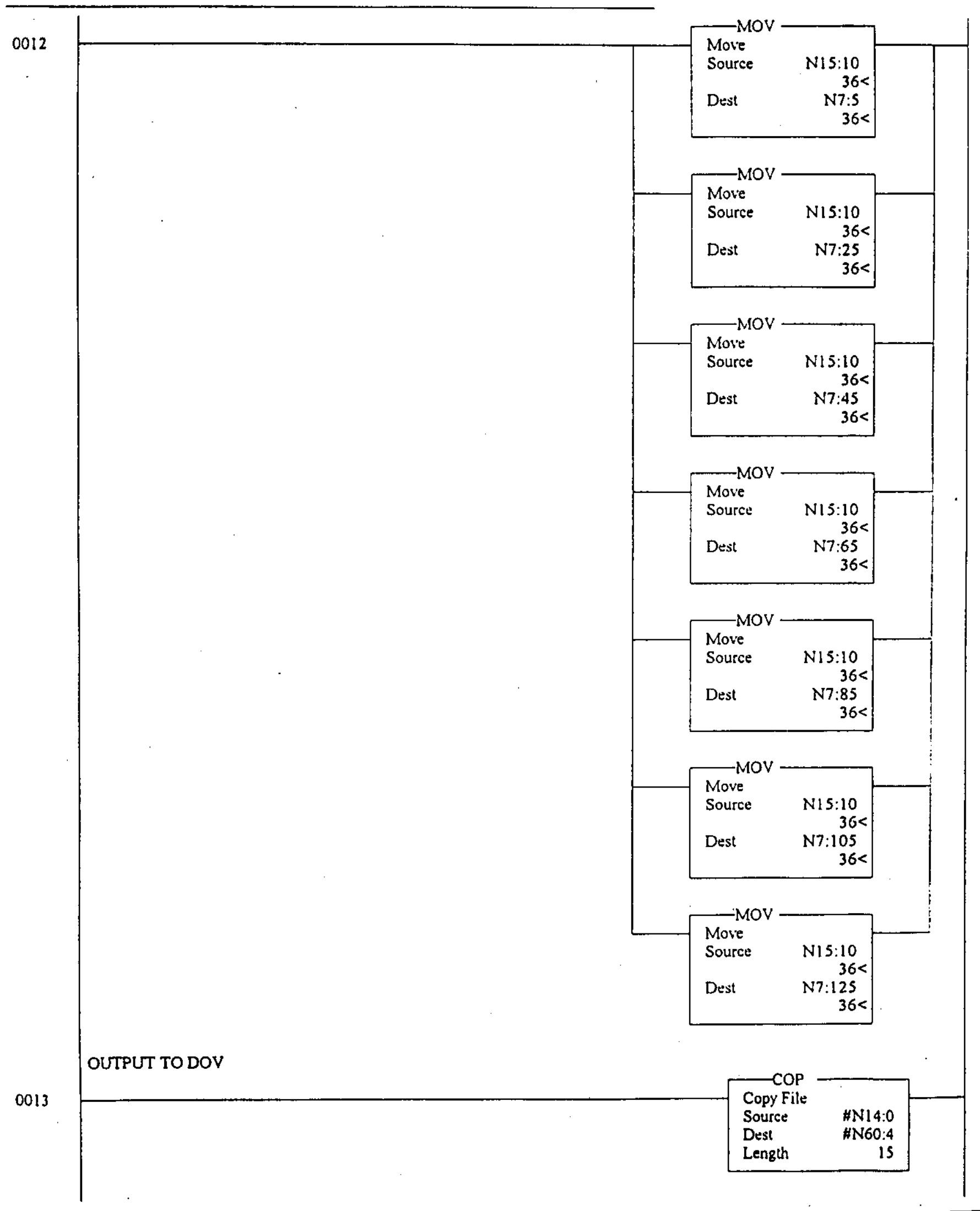

Puge 1 - 3 


\begin{tabular}{c|c|c|} 
Ul O3last.rss & LAD 3 - - Total Rungs in File $=16$ \\
\hline \multirow{2}{*}{0014} &
\end{tabular}


LAD 4 - - Total Rungs in File $=10$

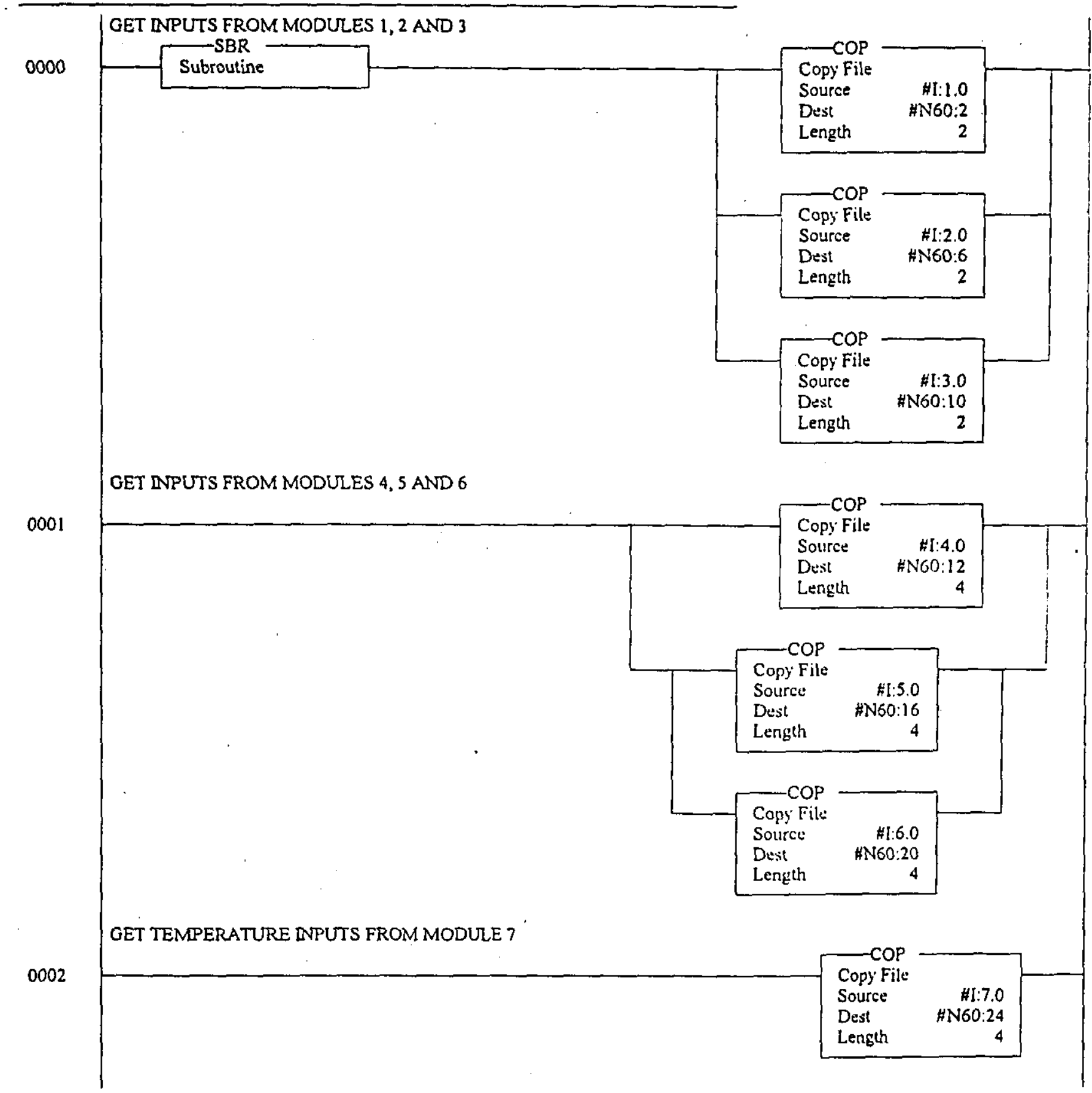


LAD 4 - - Total Rungs in File $=10$

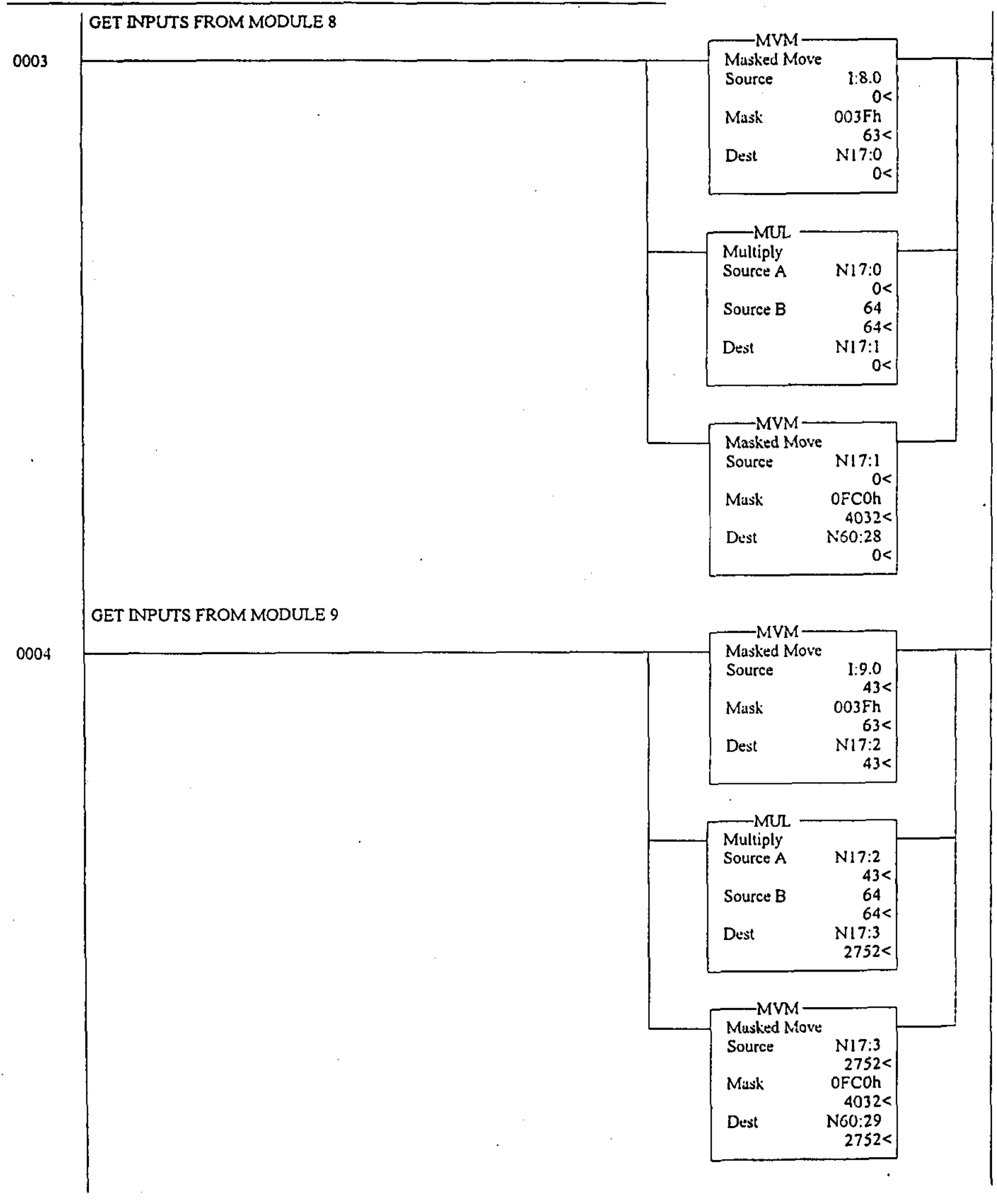


LAD 4 - - Total Rungs in File $=10$

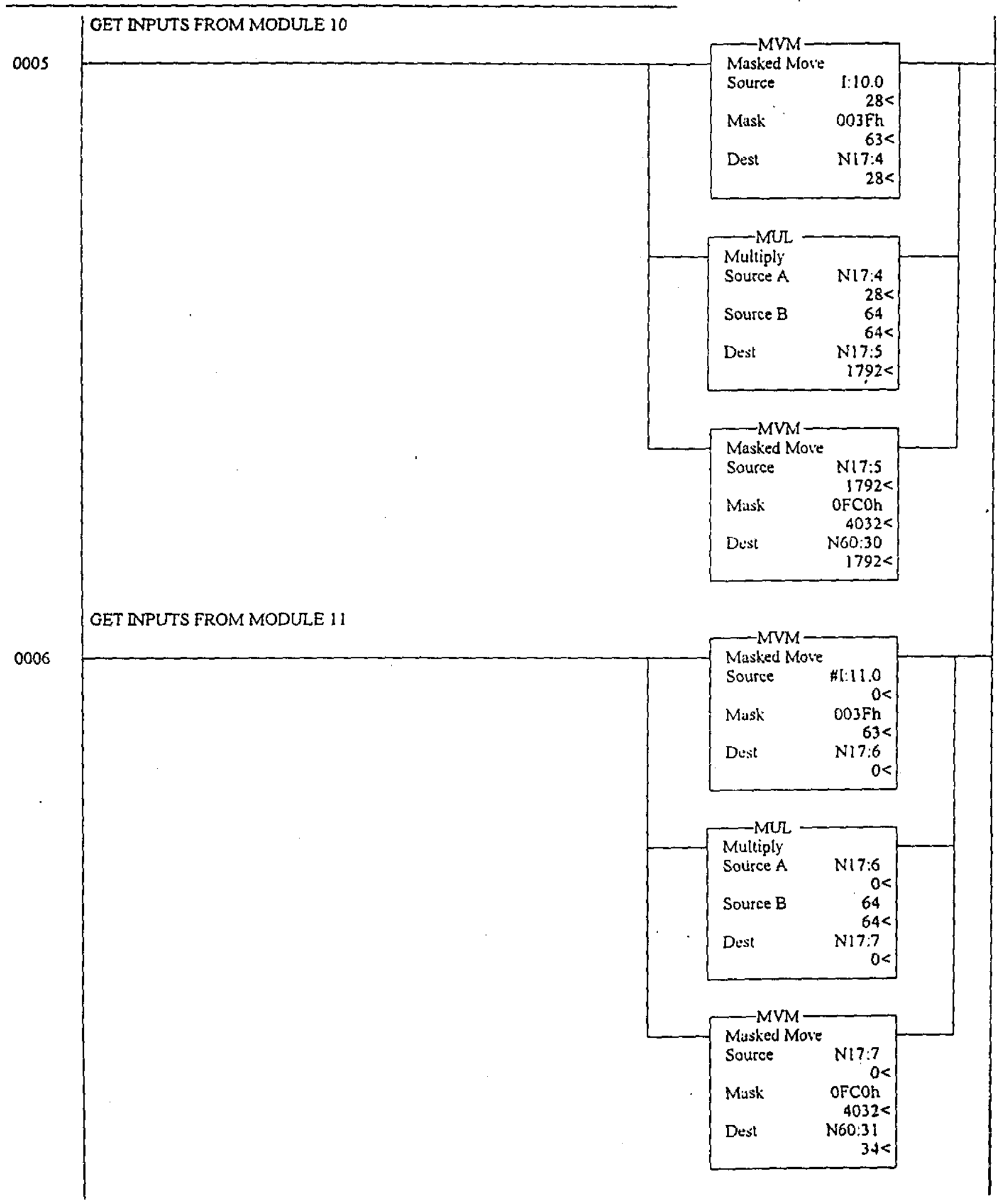


Ul03 last.rss

LAD 4 - Total Rungs in File $=10$

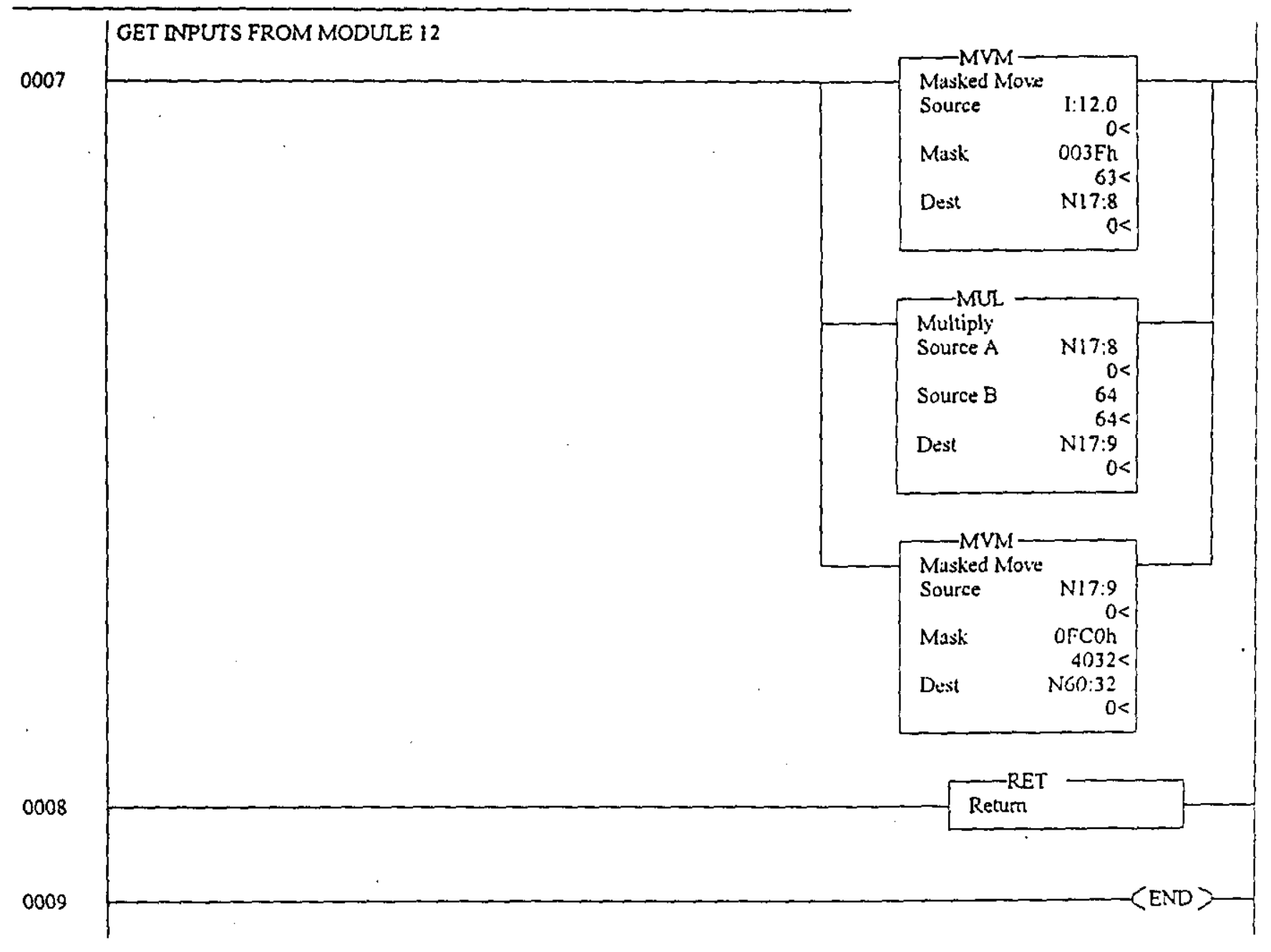

Page 1-4

Munday, September 27, $1999^{\circ}$-08:16:13 
LAD $5-$ - Total Rungs in File $=105$

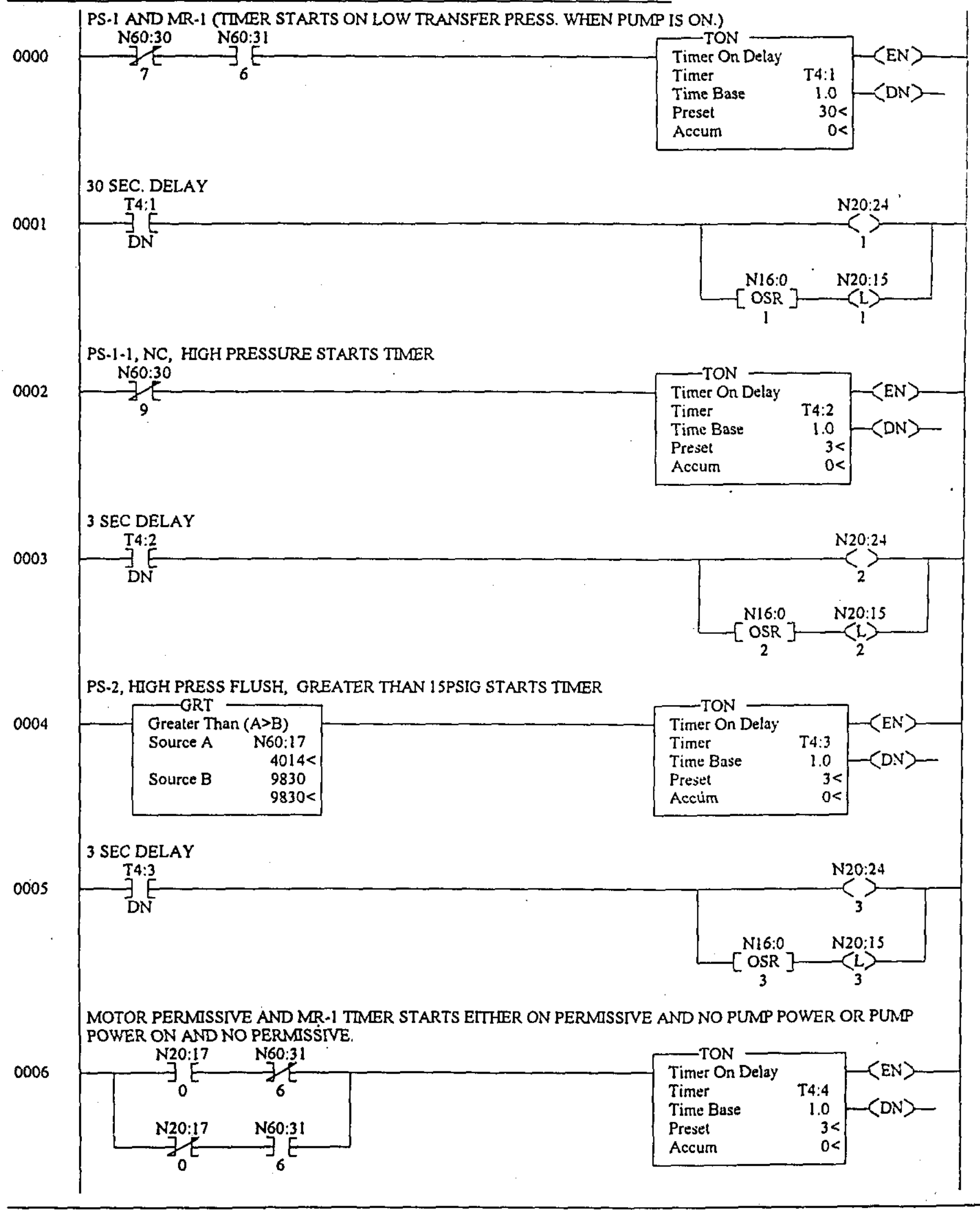


LAD 5 - - Total Rungs in File $=105$

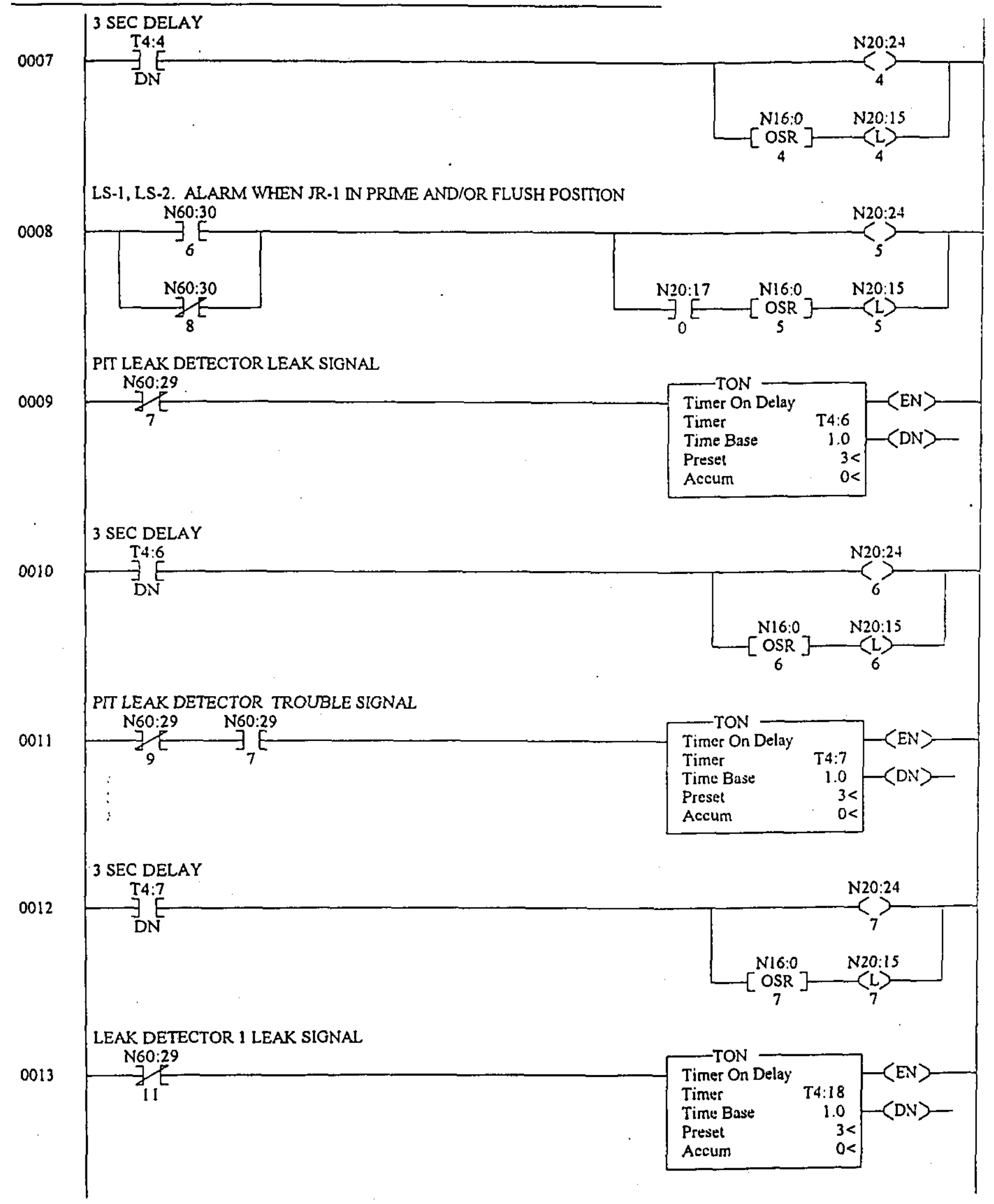


LAD 5. .- Total Rungs in File $=105$

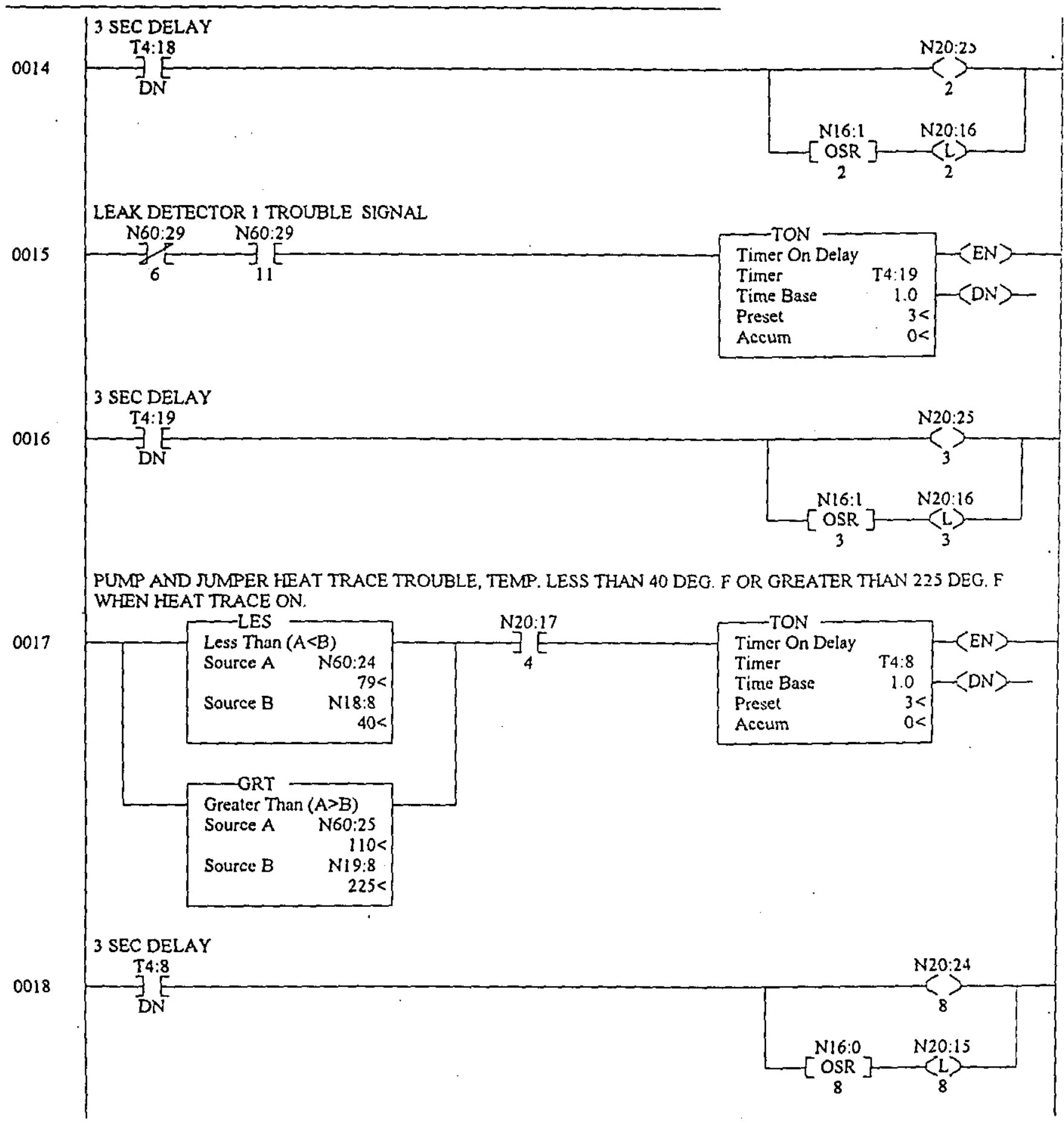


LAD 5 - Total Rungs in File $=105$

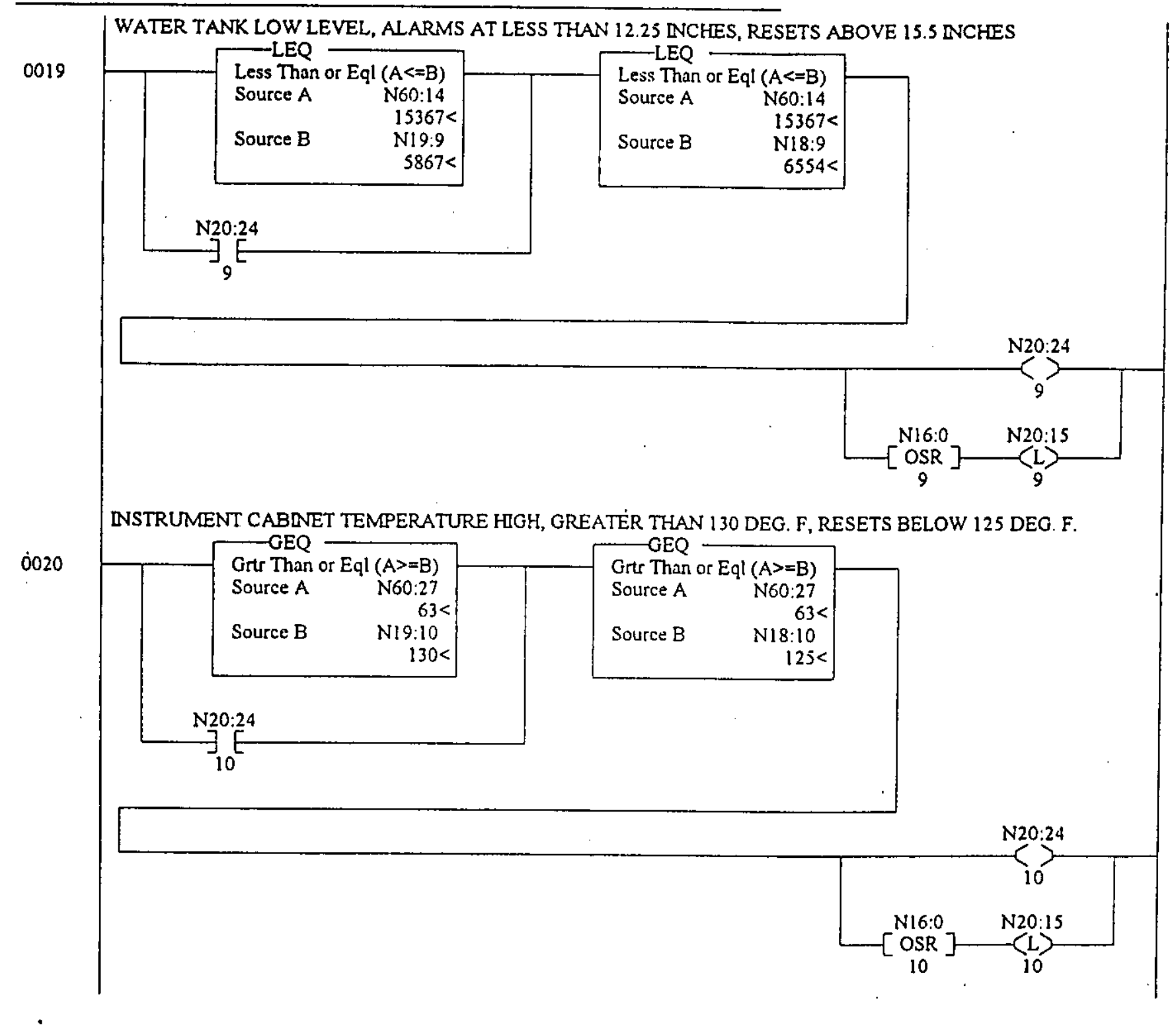




\section{Ul03last.rss}

LAD 5 - - Total Rungs in File $=105$

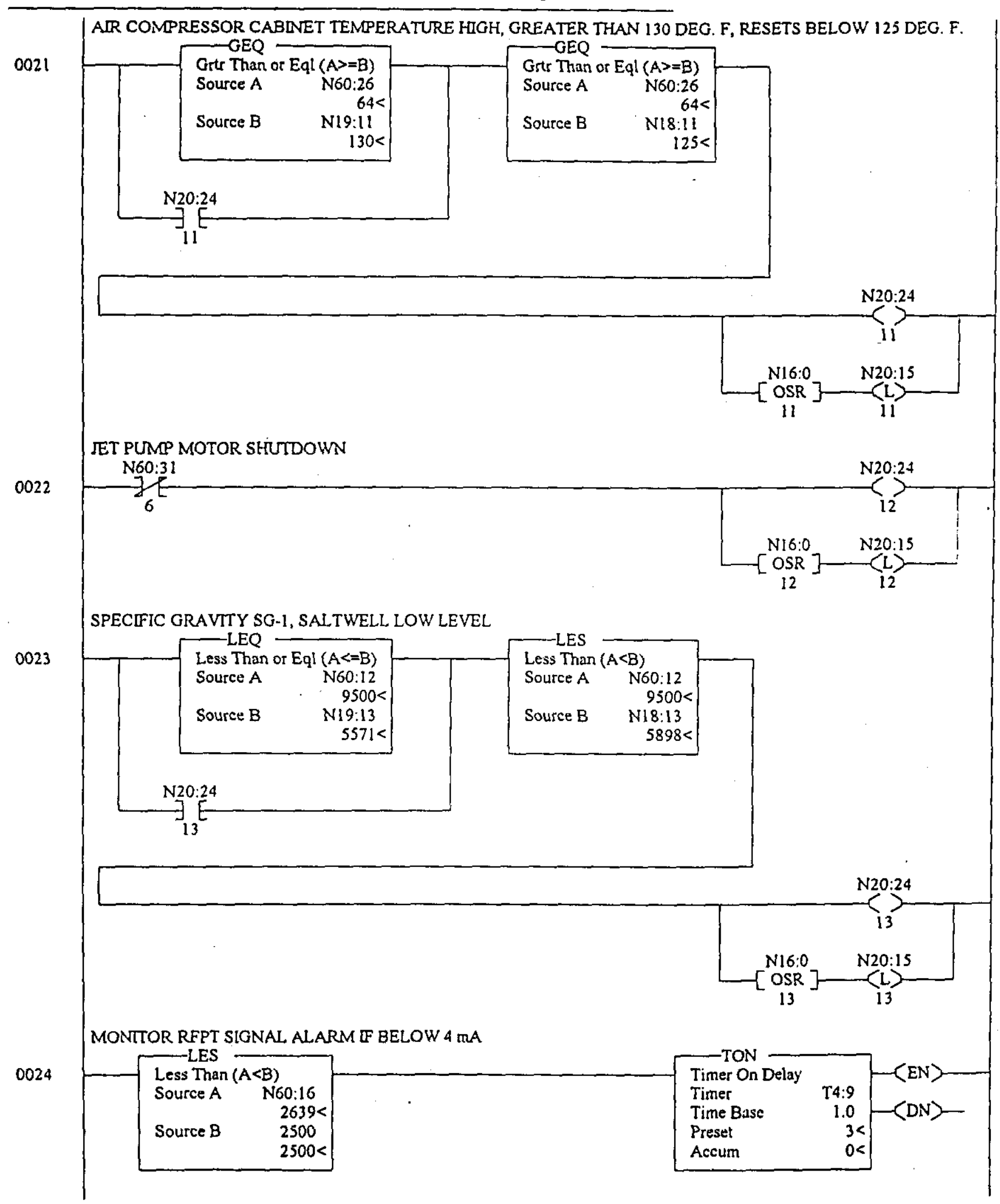


LAD S - - Total Rungs in File $=105$

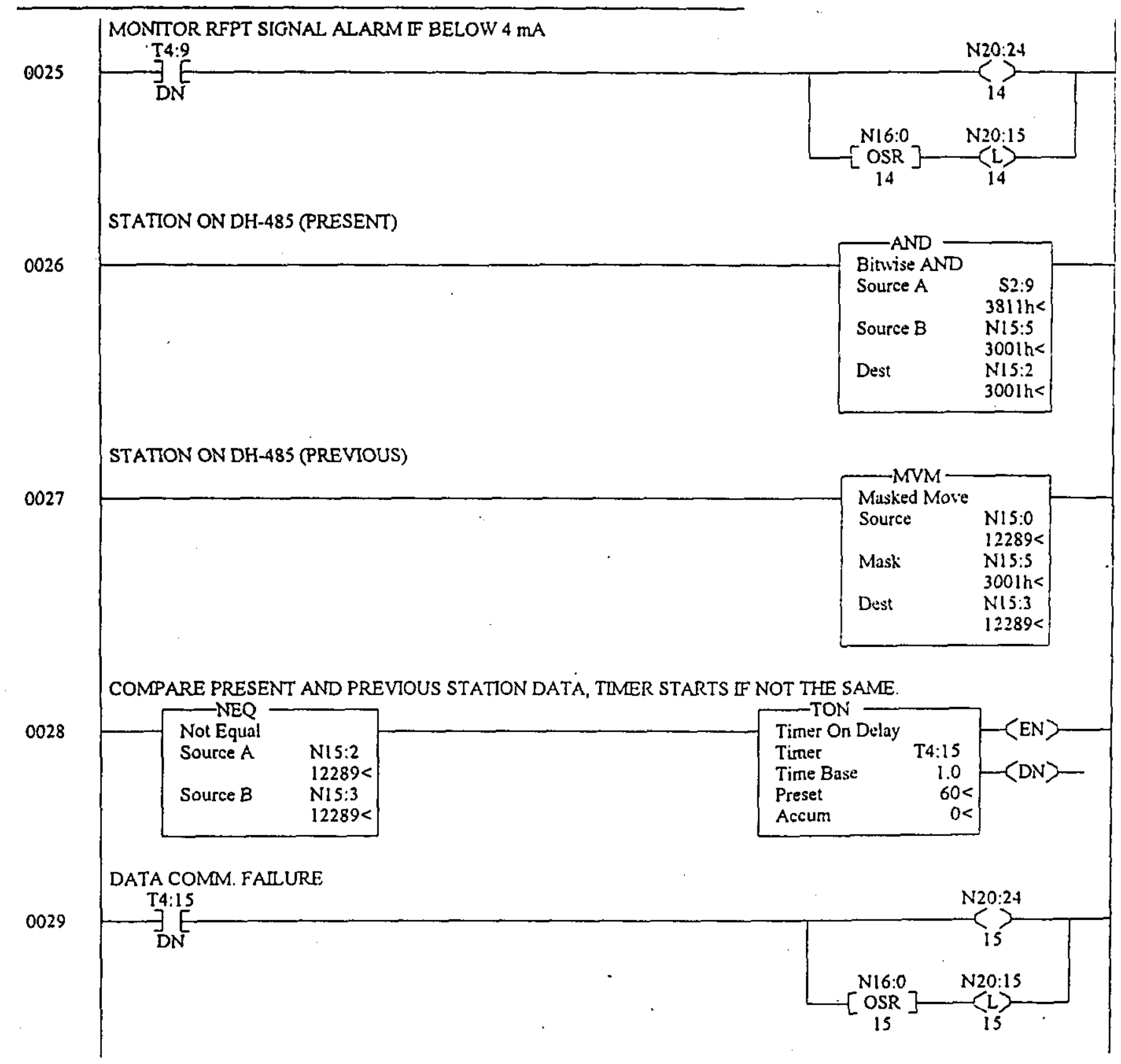


LAD 5 - - Total Rungs in File $\approx 105$

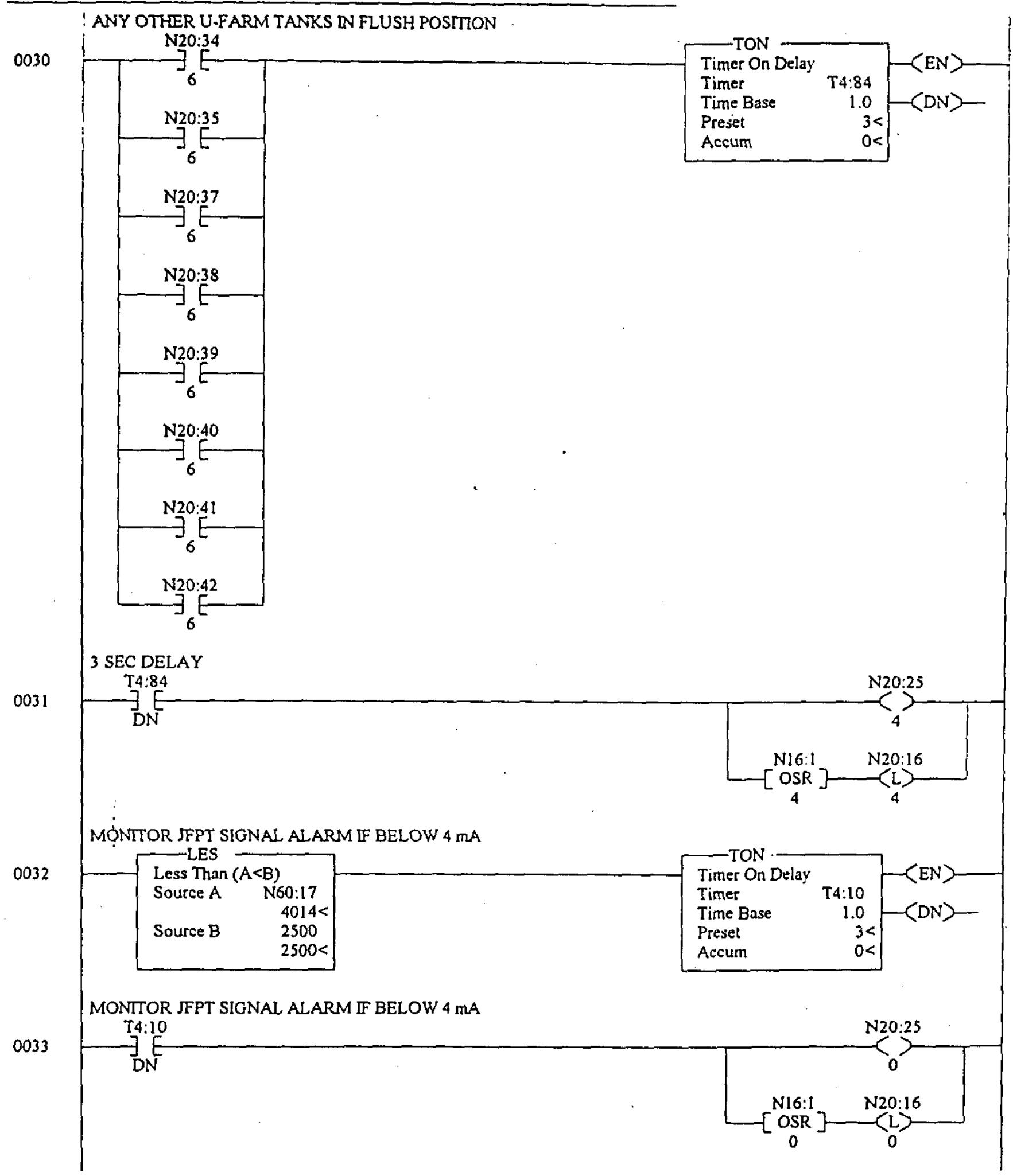


U103last.rss

LAD 5 - Tolal Rungs in File $=105$

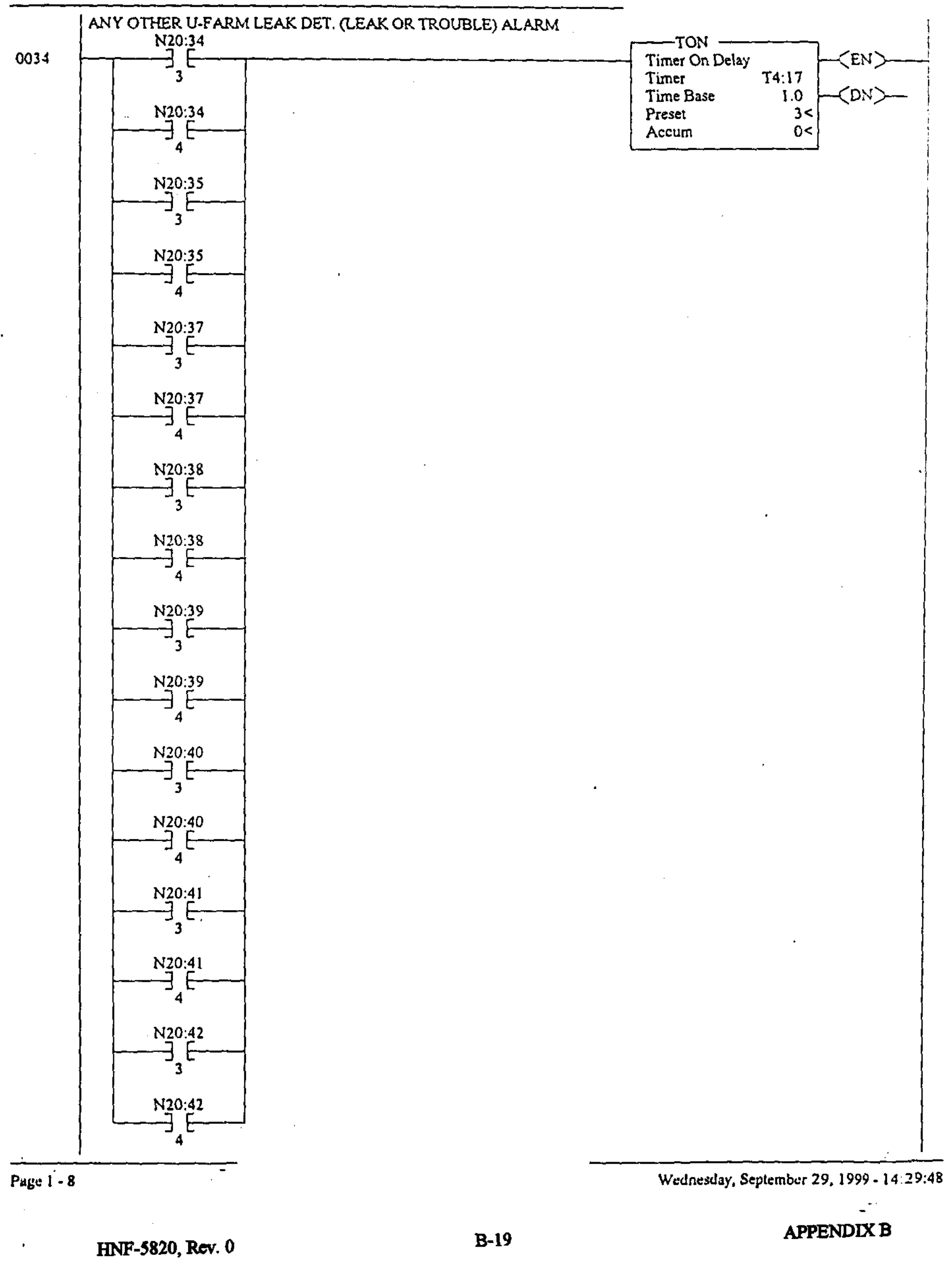


LAD 5. - Total Rungs in File $=105$

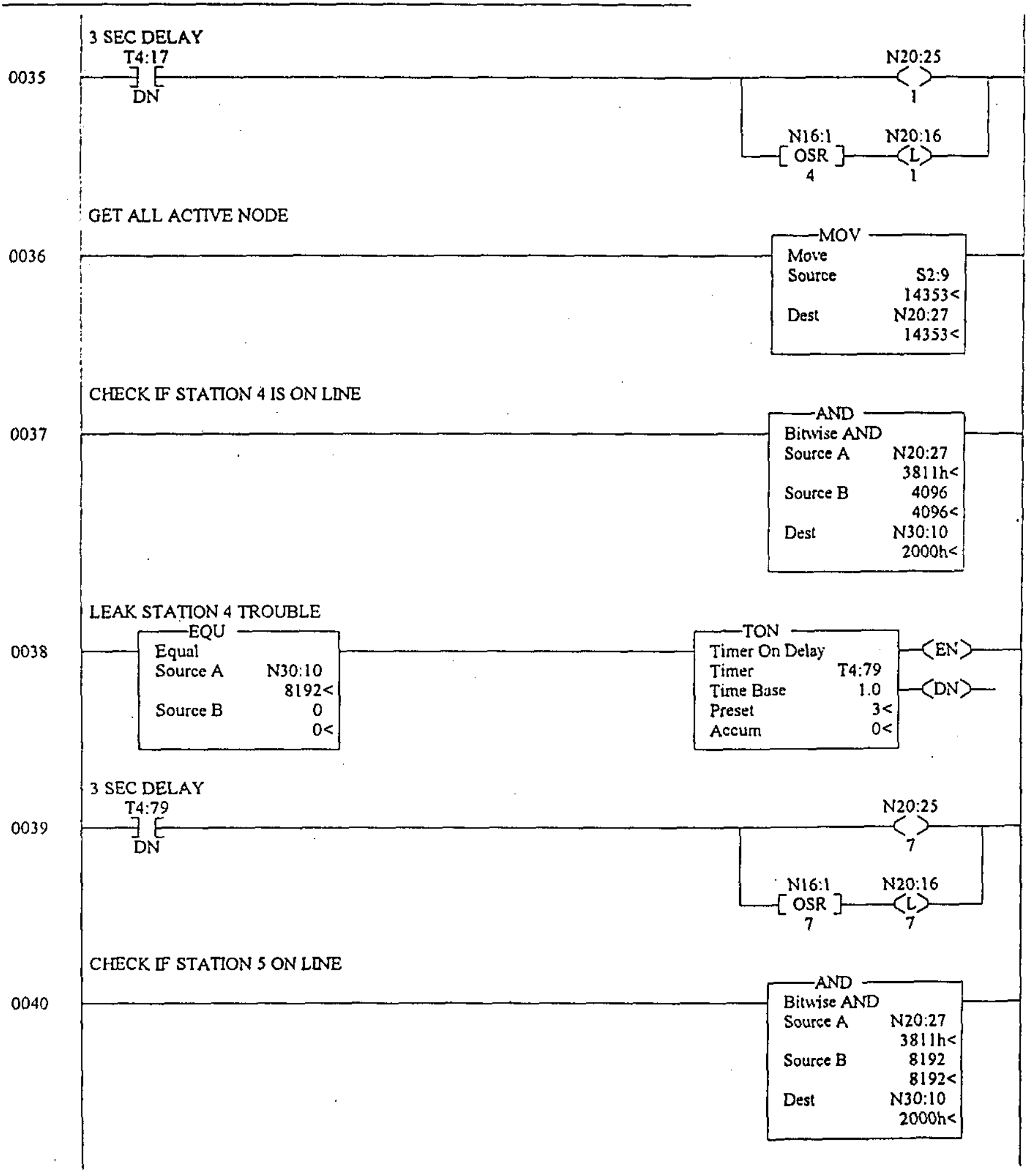


LAD 5 - Total Rungs in File $=105$

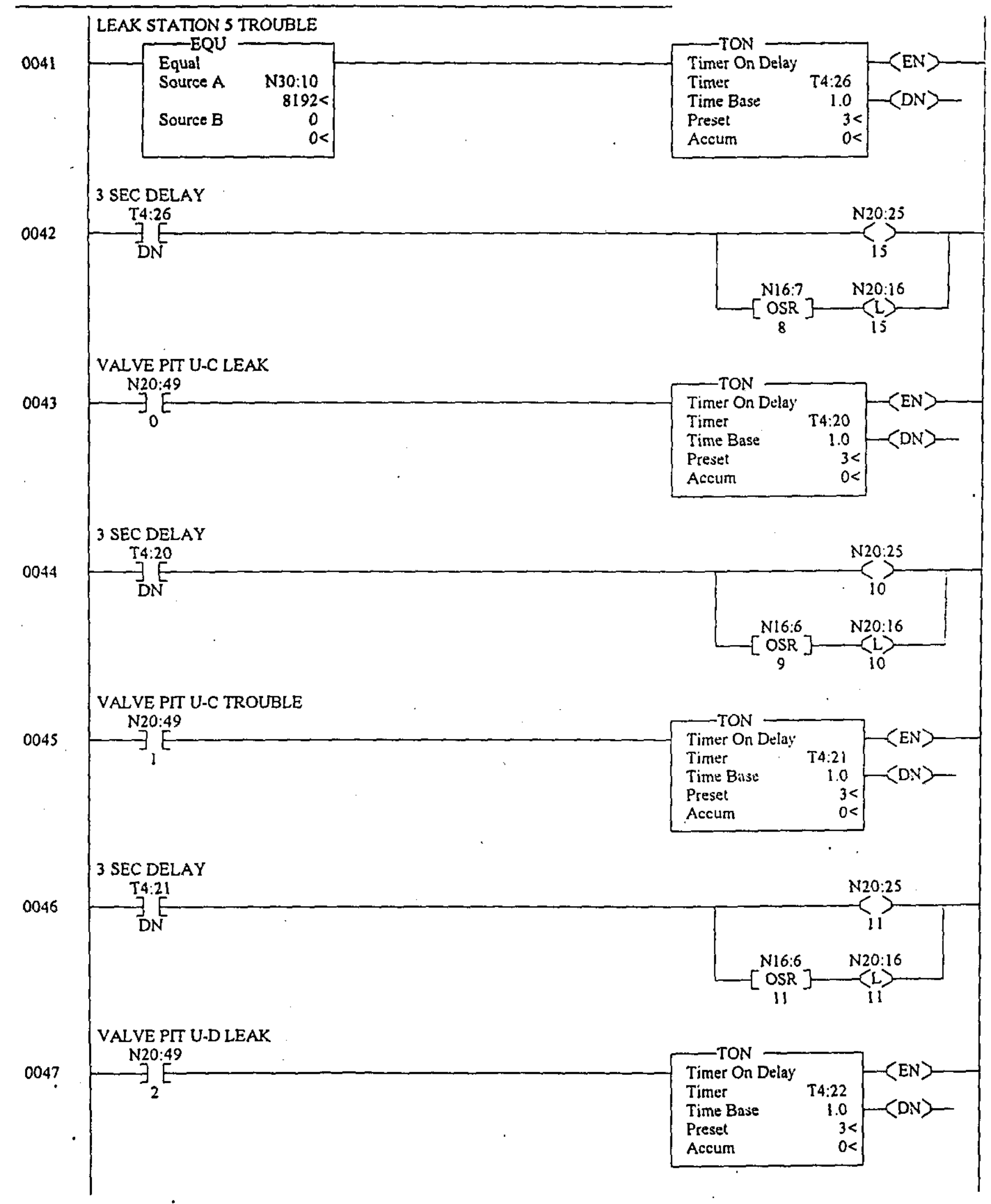


LAD 5 . - Total Rungs in File $=105$

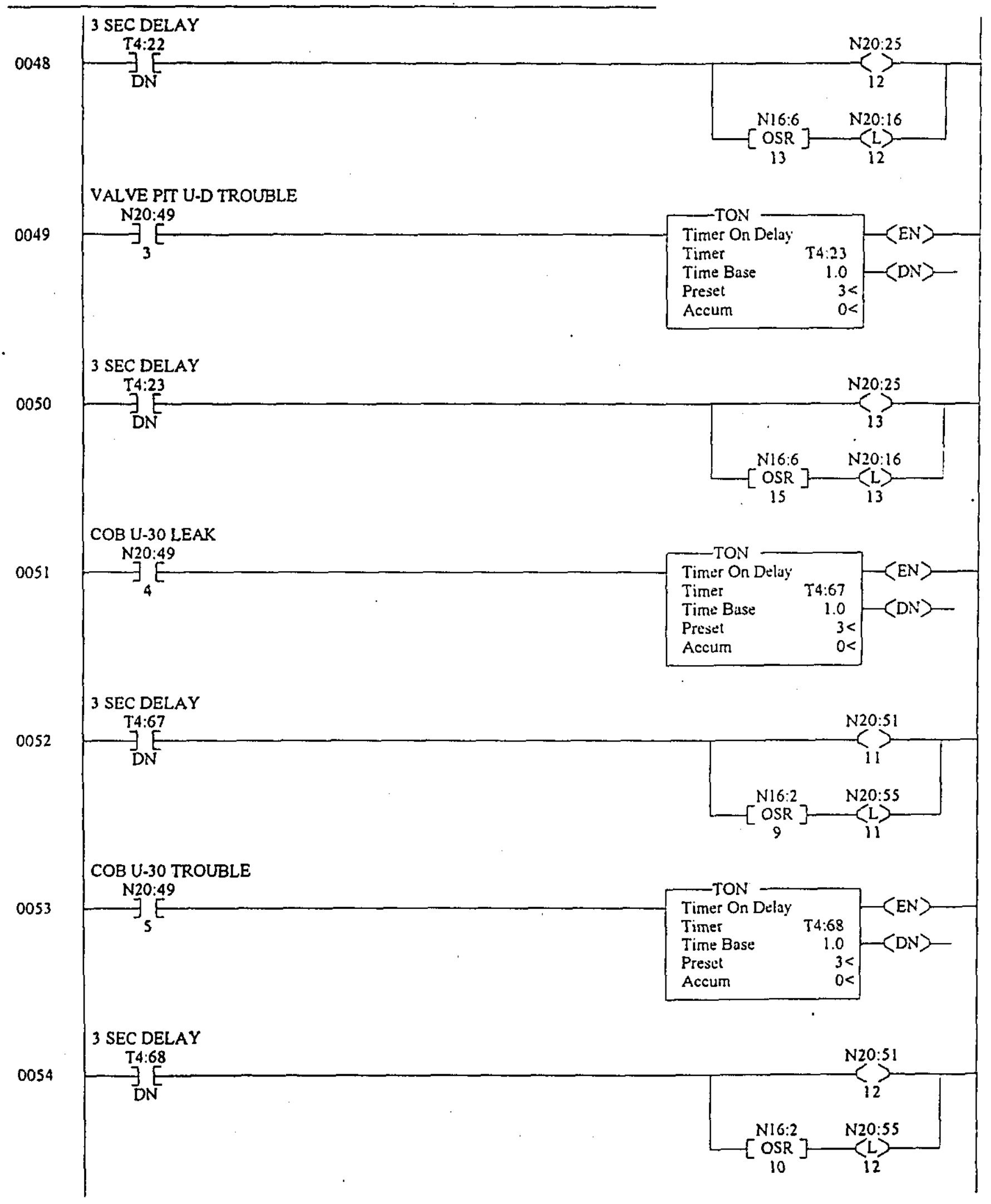




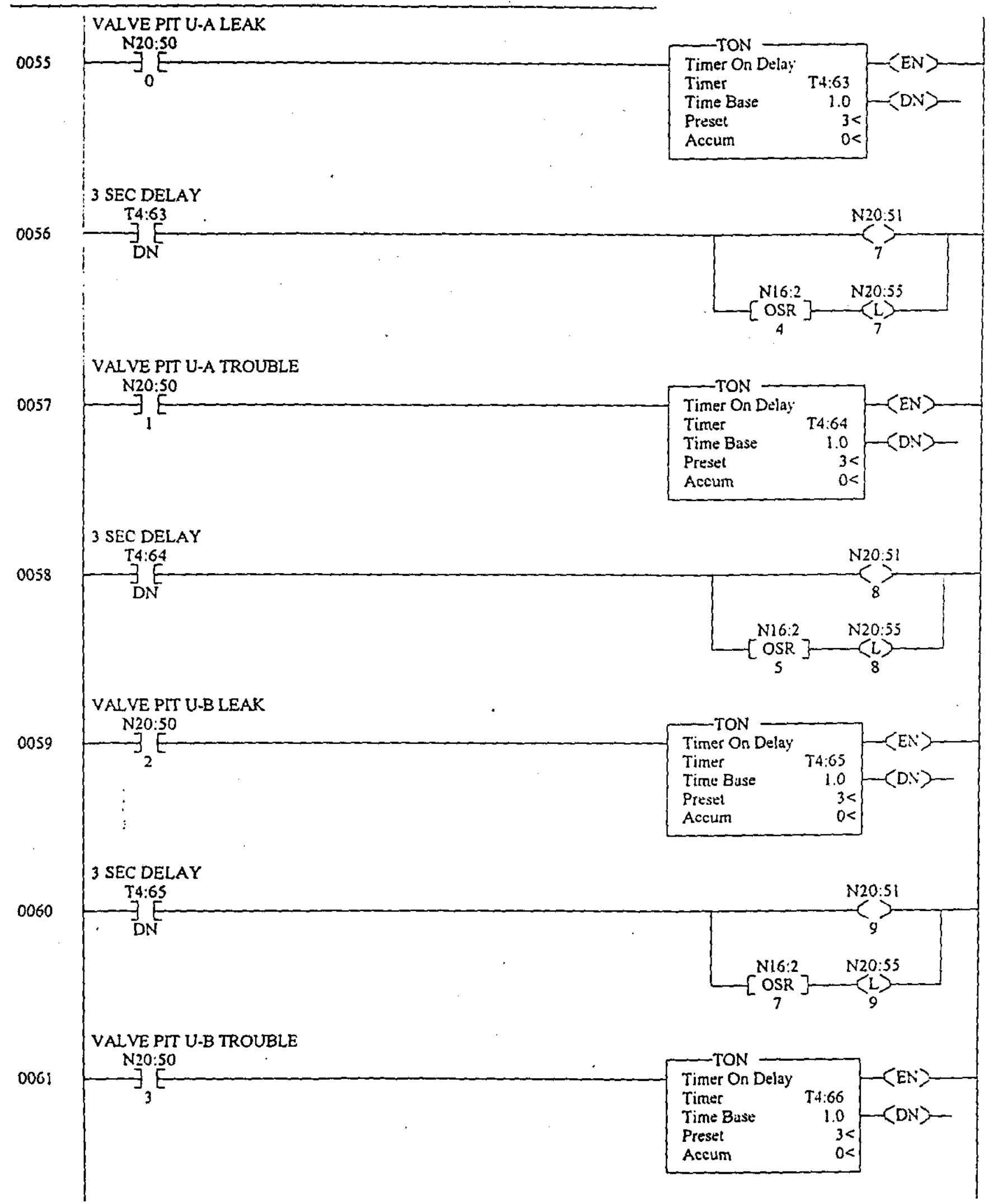

Page 1 12

Wednesday, September 29, $1999 \cdot 14: 29: 48$ 
LAD 5 - Total Rungs in File $=105$

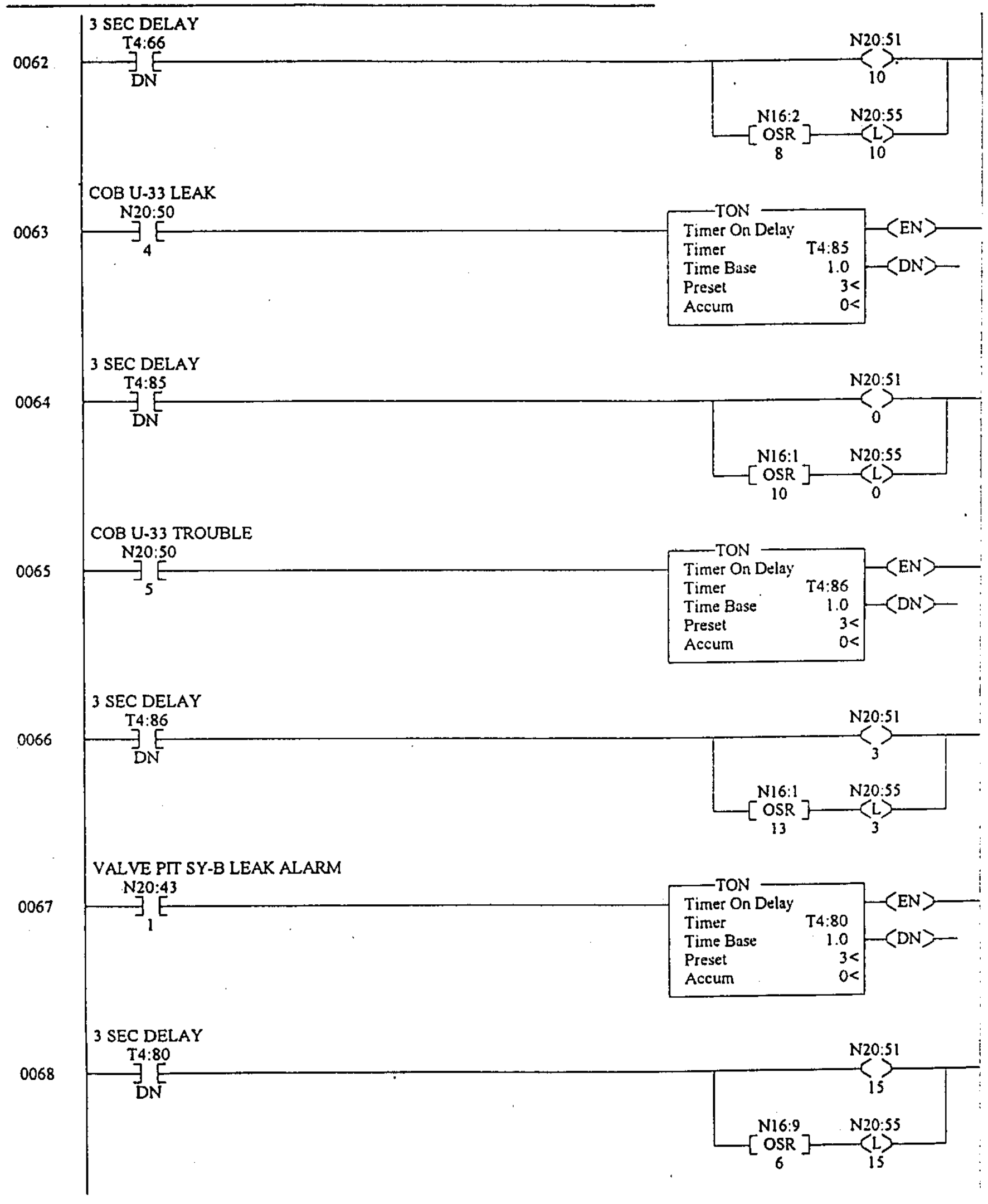


U103last.rss

LAD 5 - Total Rungs in File $=105$

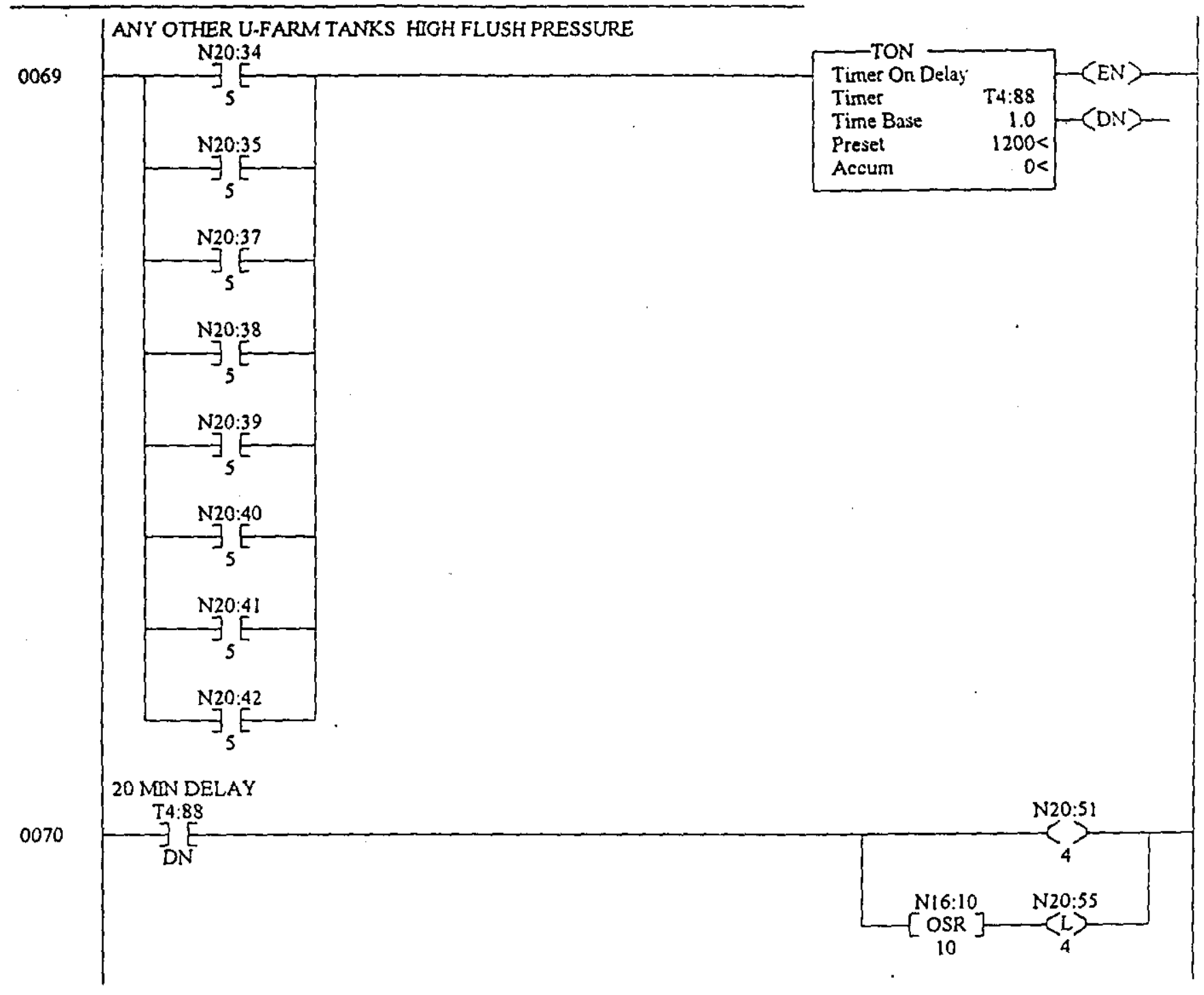


LAD 5 - - Total Rungs in File $=105$

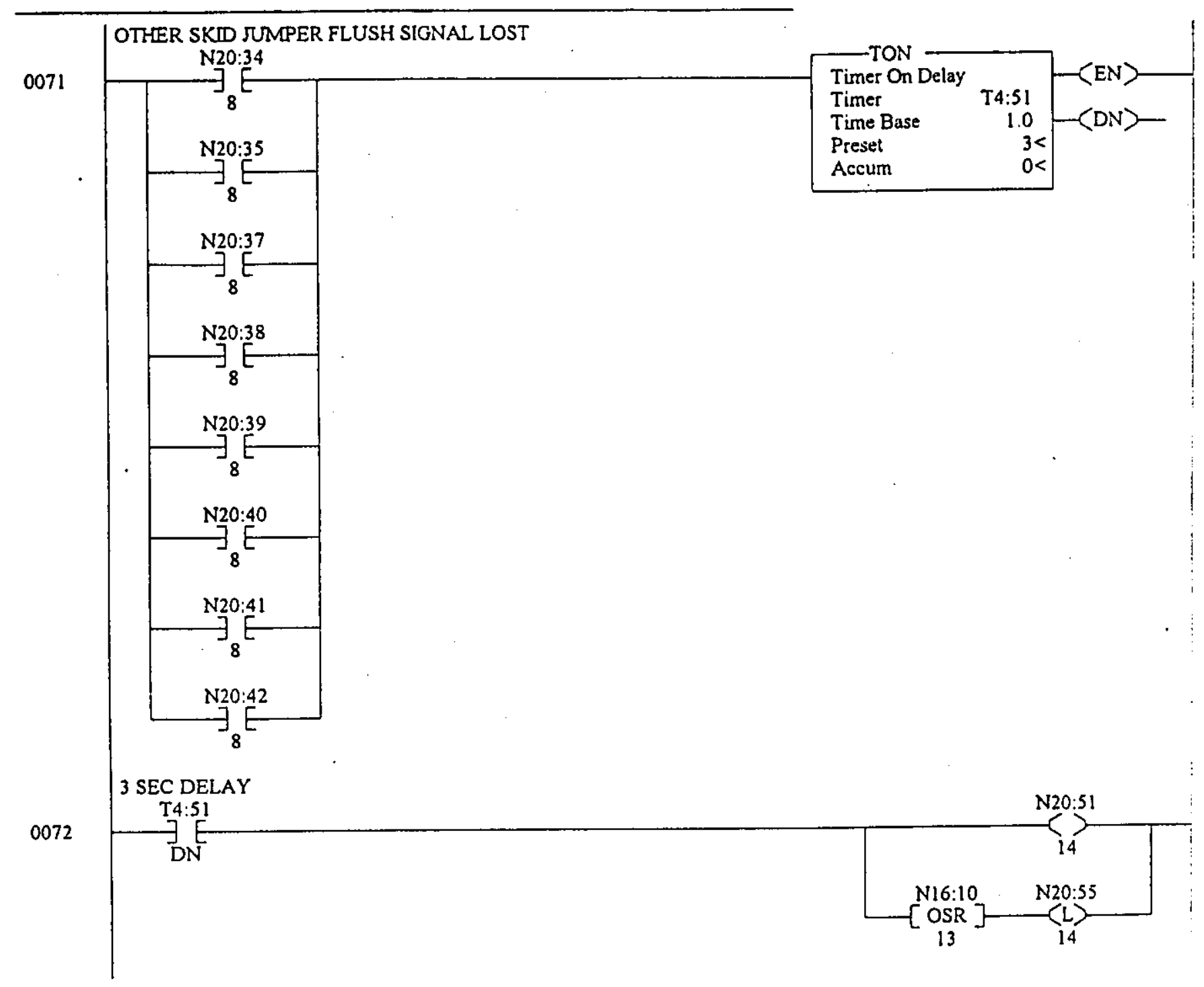


U103last.rss

LAD 5 - Tatal Rungs in File $=105$

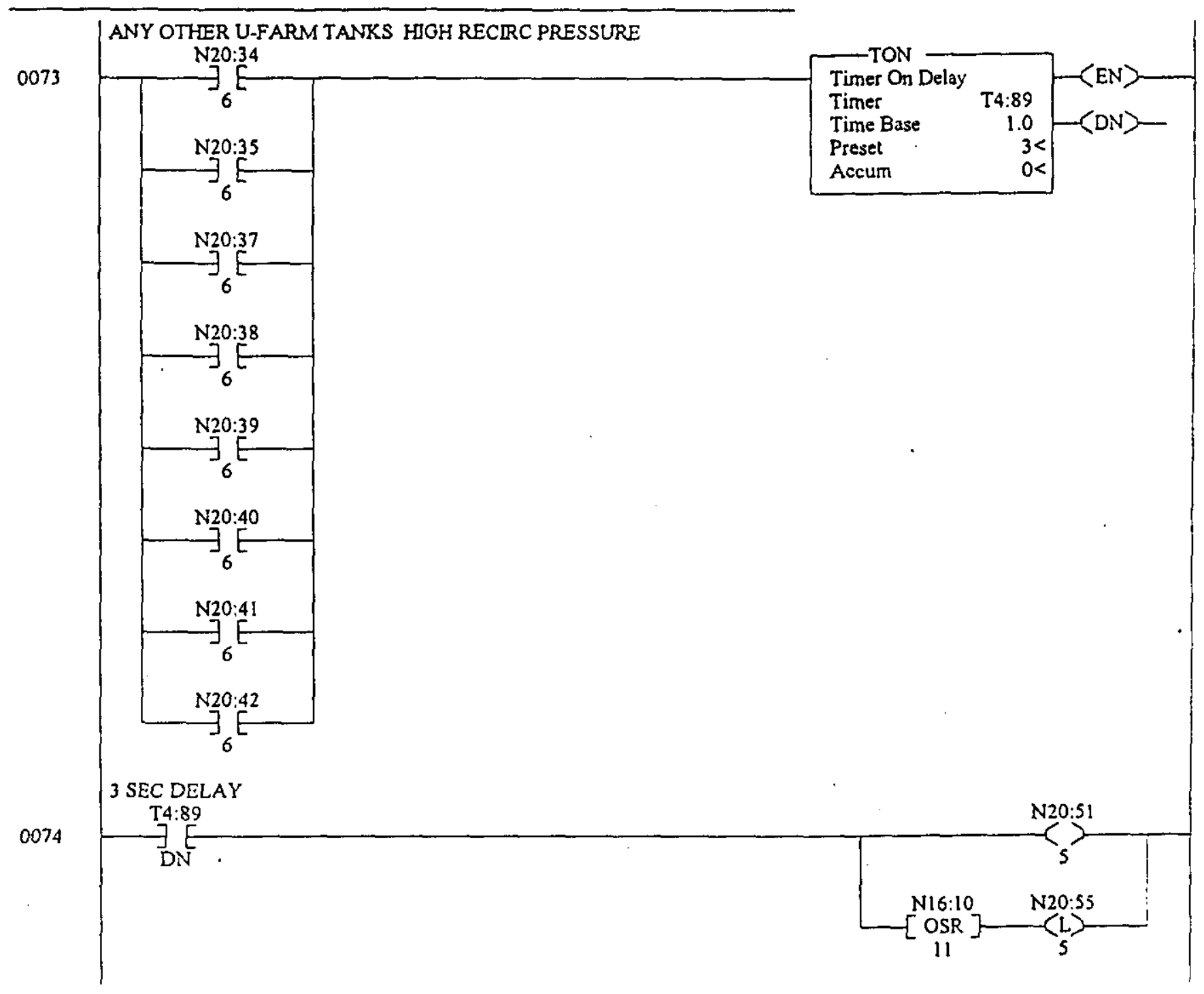


Ul03tast.rss

LAD 5 - - Total Rungs in File $=105$

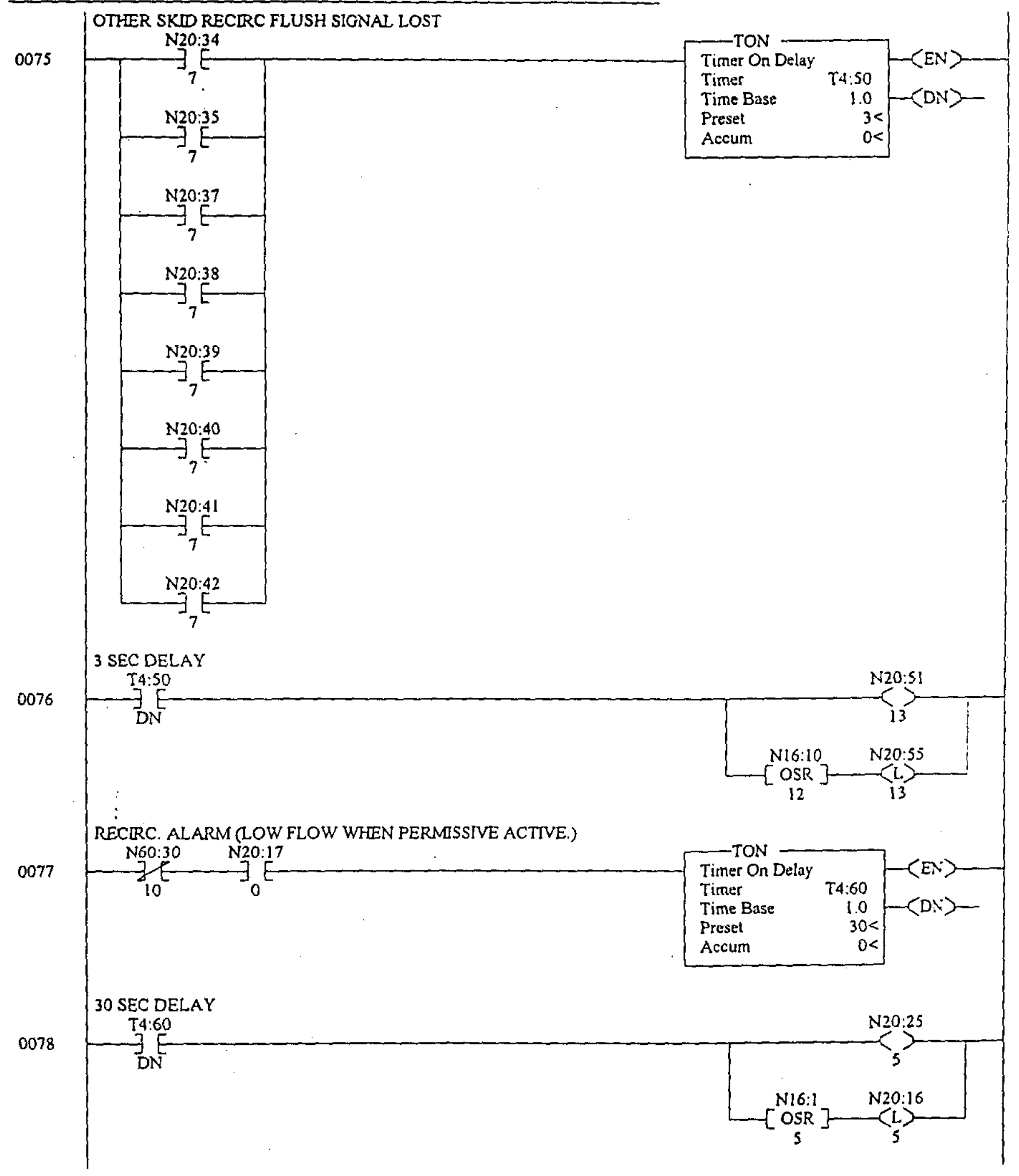




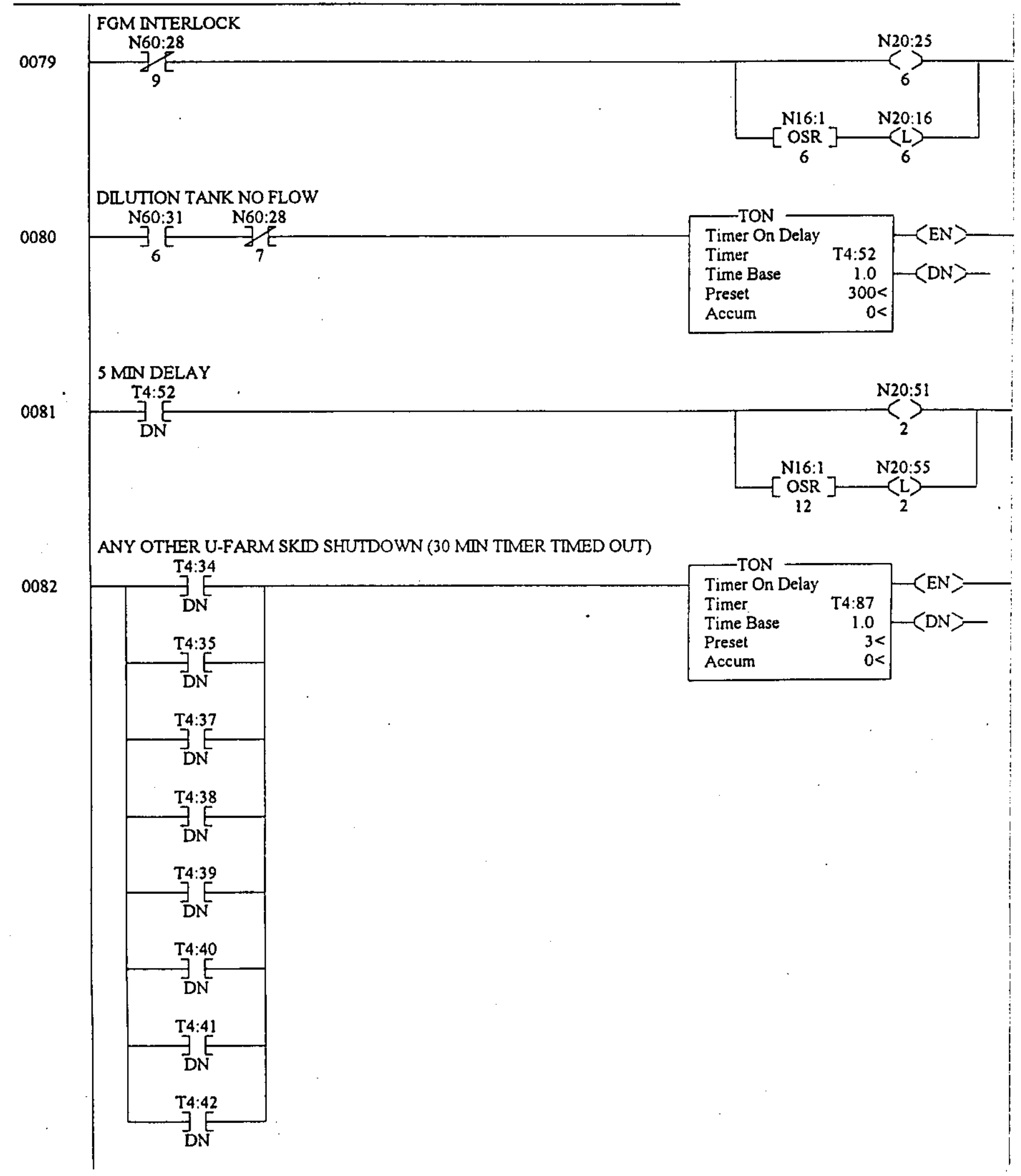




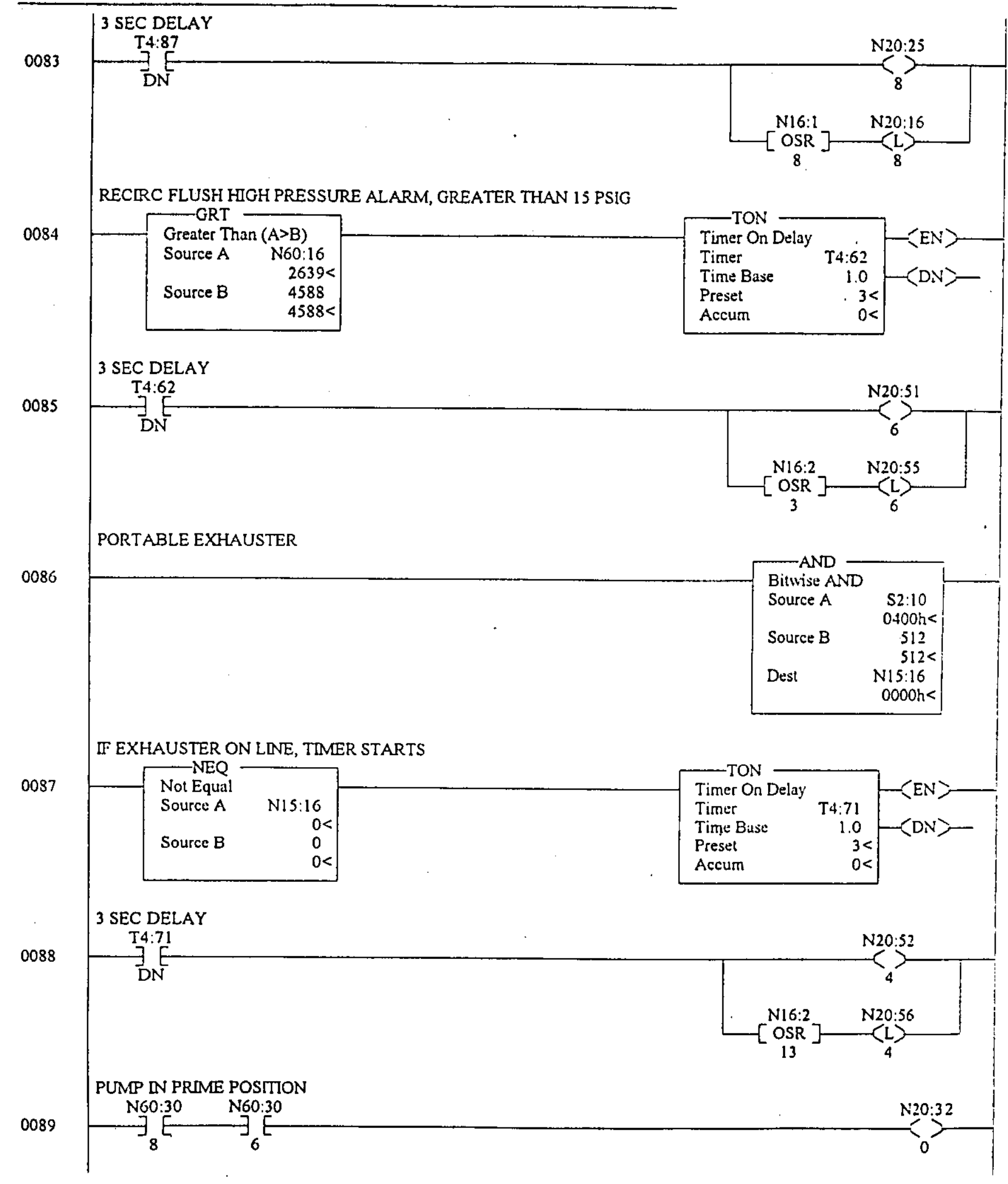


U103last.rss

LAD 5 - - Total Rungs in File $=105$

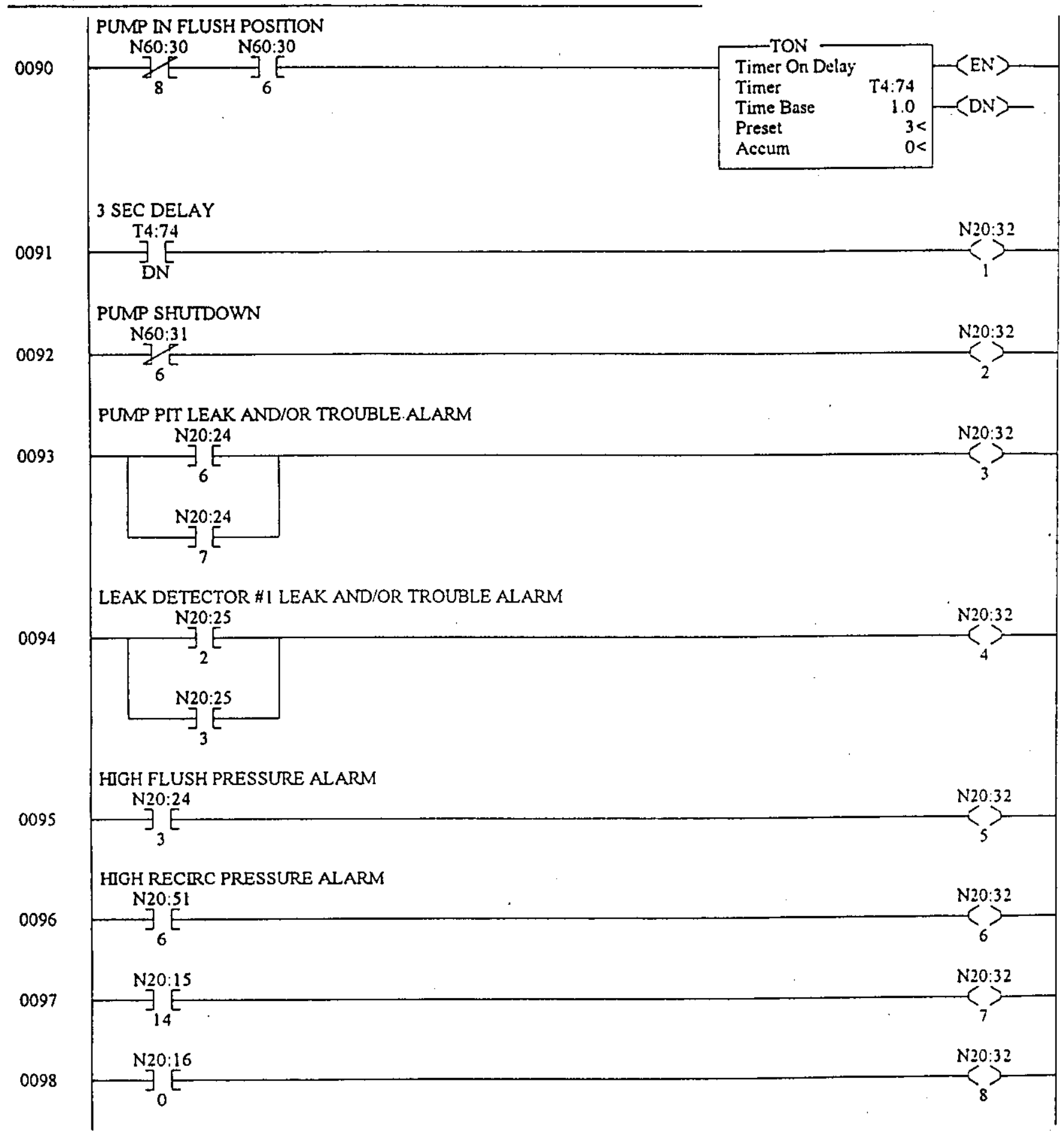


U103last.rss

LAD 5 - - Total Rungs in File $=105$

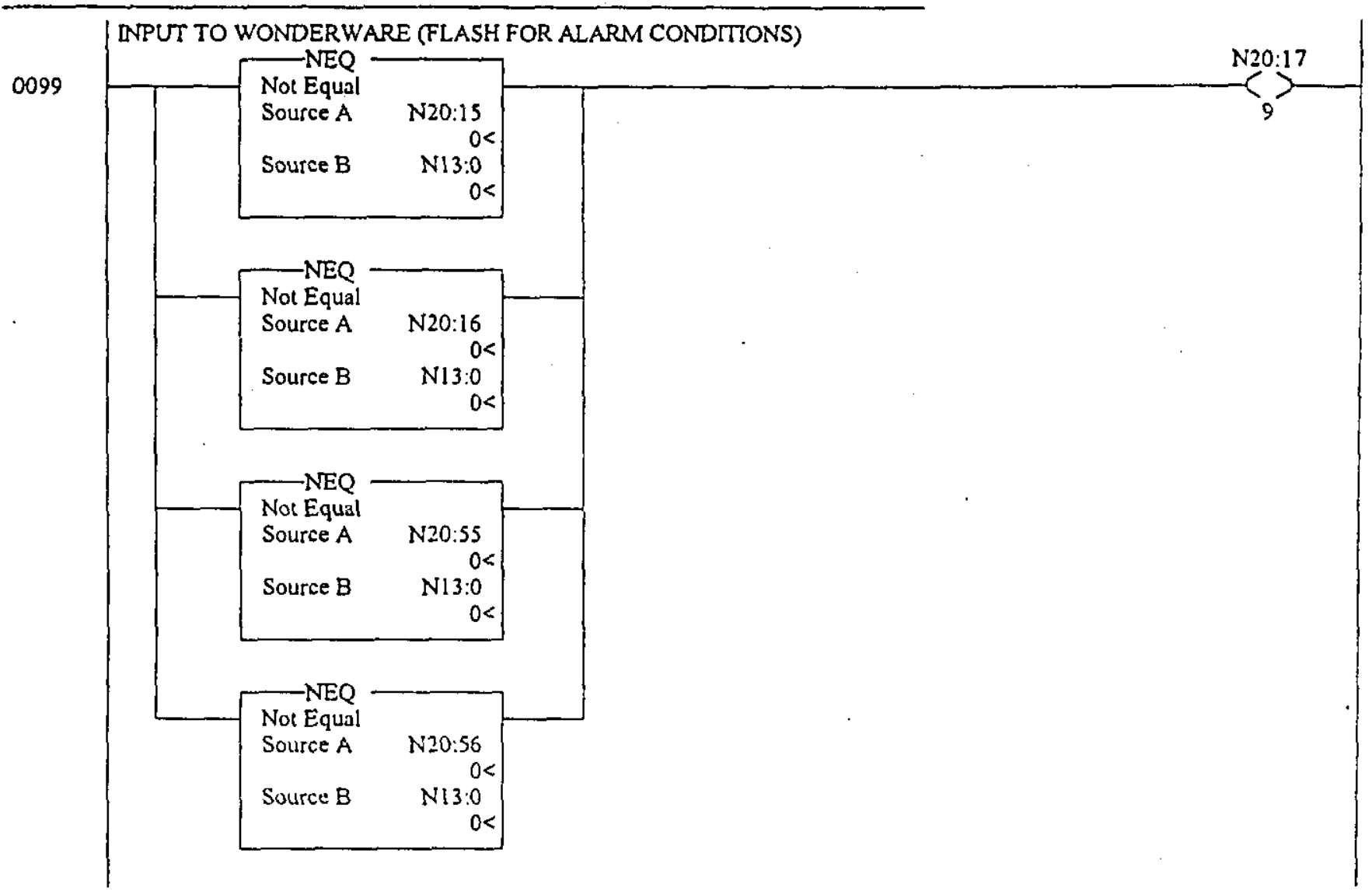


U103last.rss

LAD 5 -... Total Rungs in File $=105$

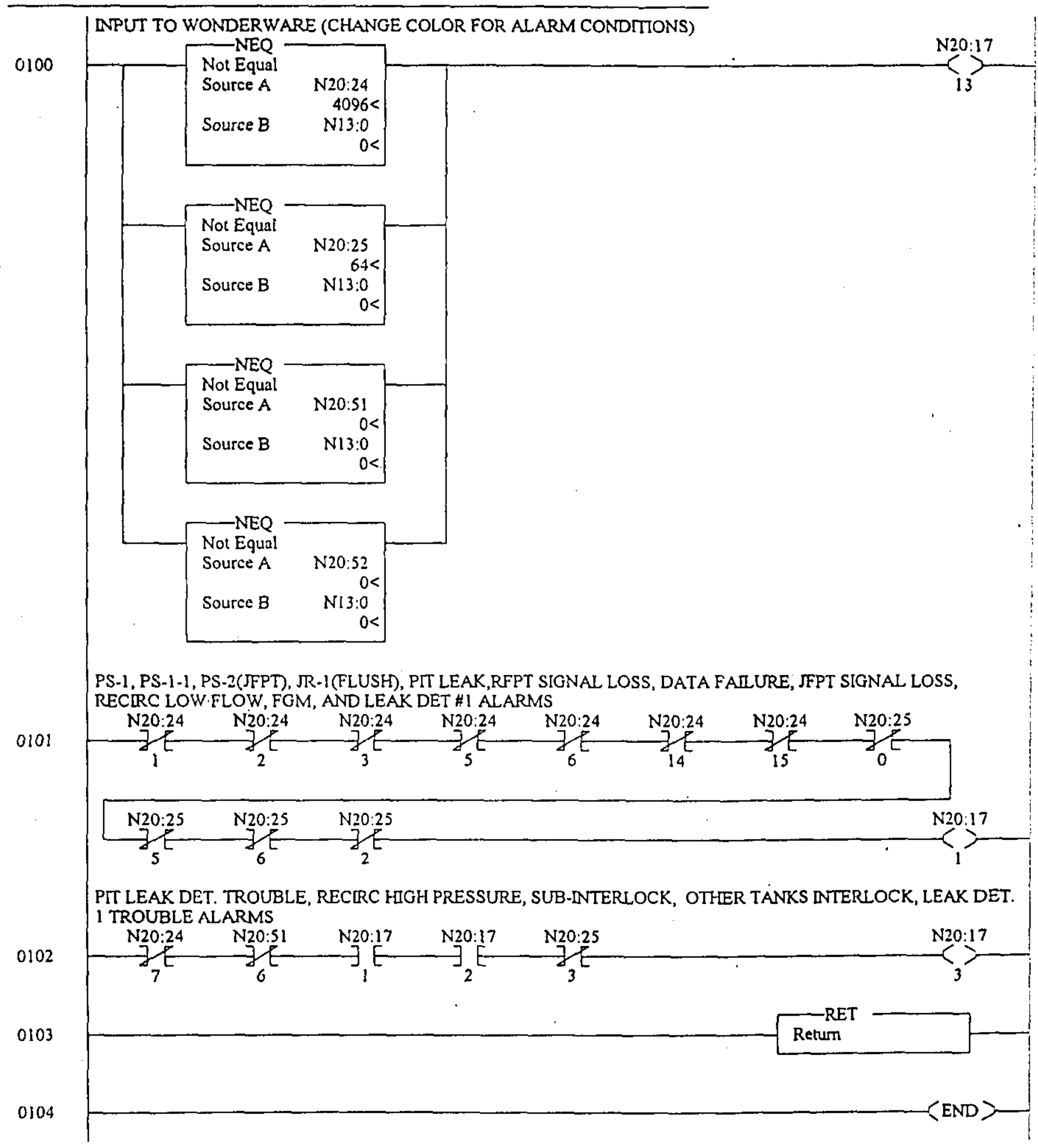


Ul03last.rss

LAD 6 . .-. Total Rungs in File $=6$

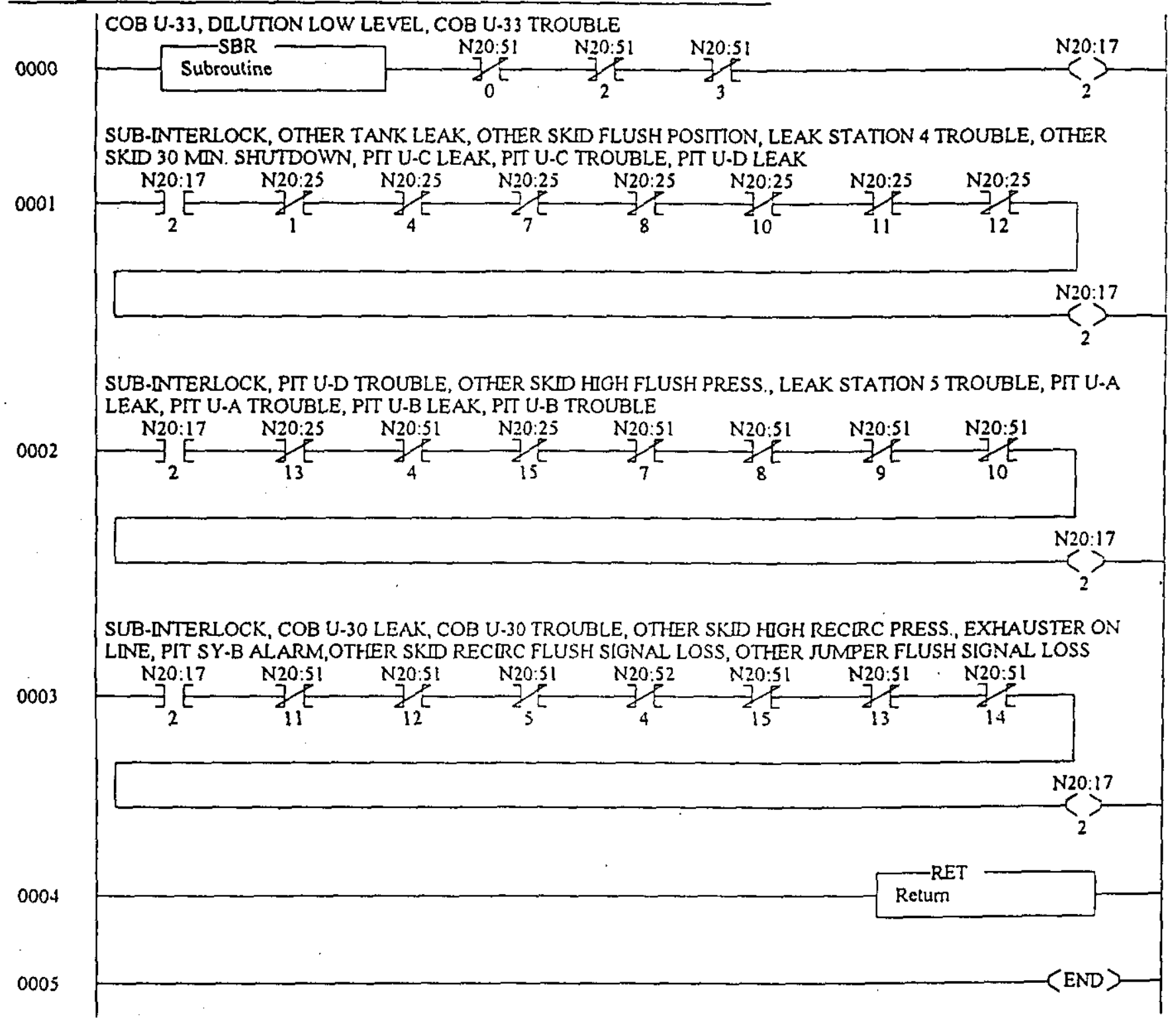


U103lastrss

LAD 7 - Total Rungs in File $=22$

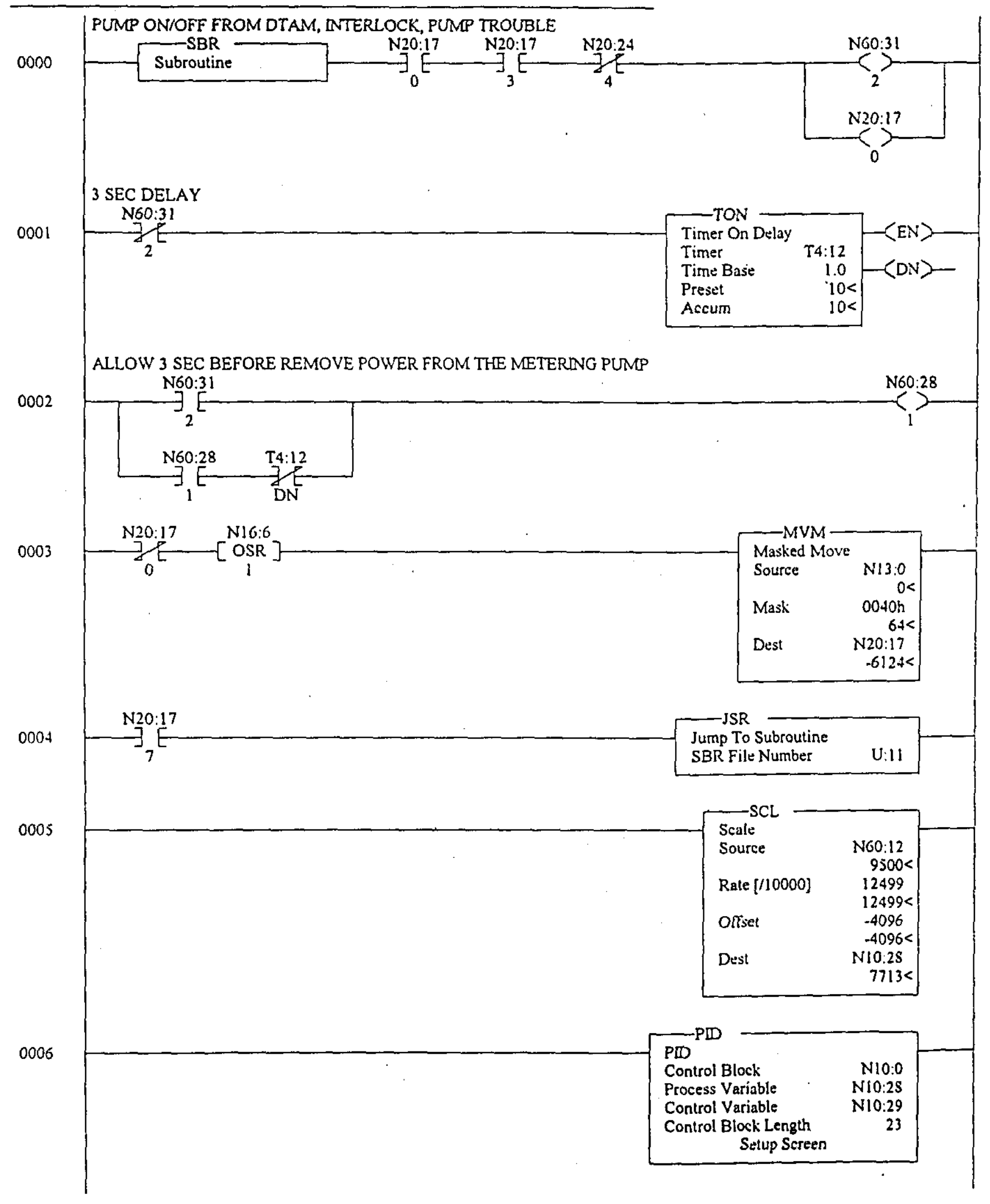

Puge 1 - 1

Monday, September 27, $1999-08: 16: 18$ 


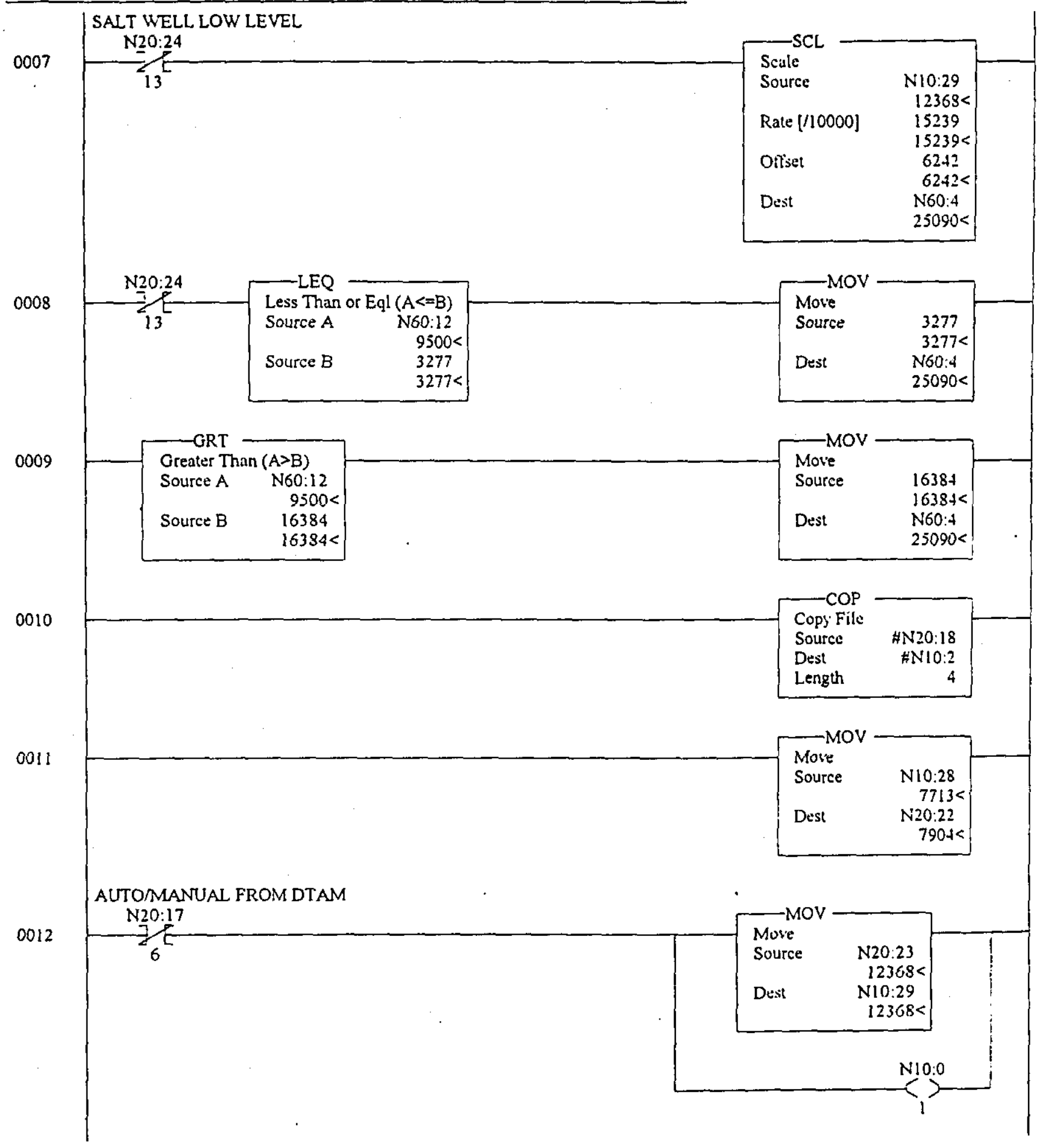


LAD 7 - - Total Rungs in File $=22$

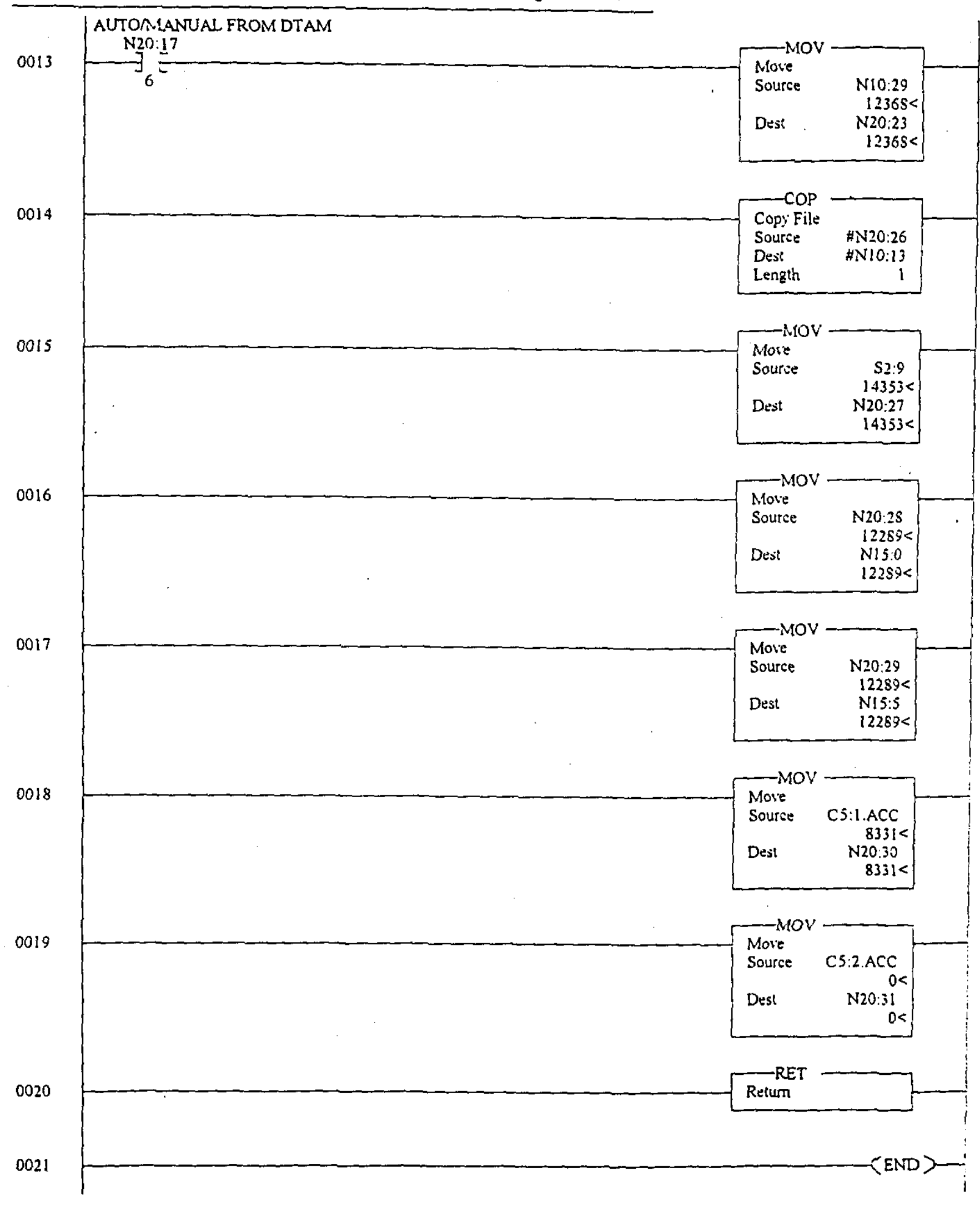

Page $1 \cdot 3$

Monday, September 27, 1999 - 08:16:19

HNF-5820, Rev. 0 
LAD 8 - -.- Total Rungs in File $=6$

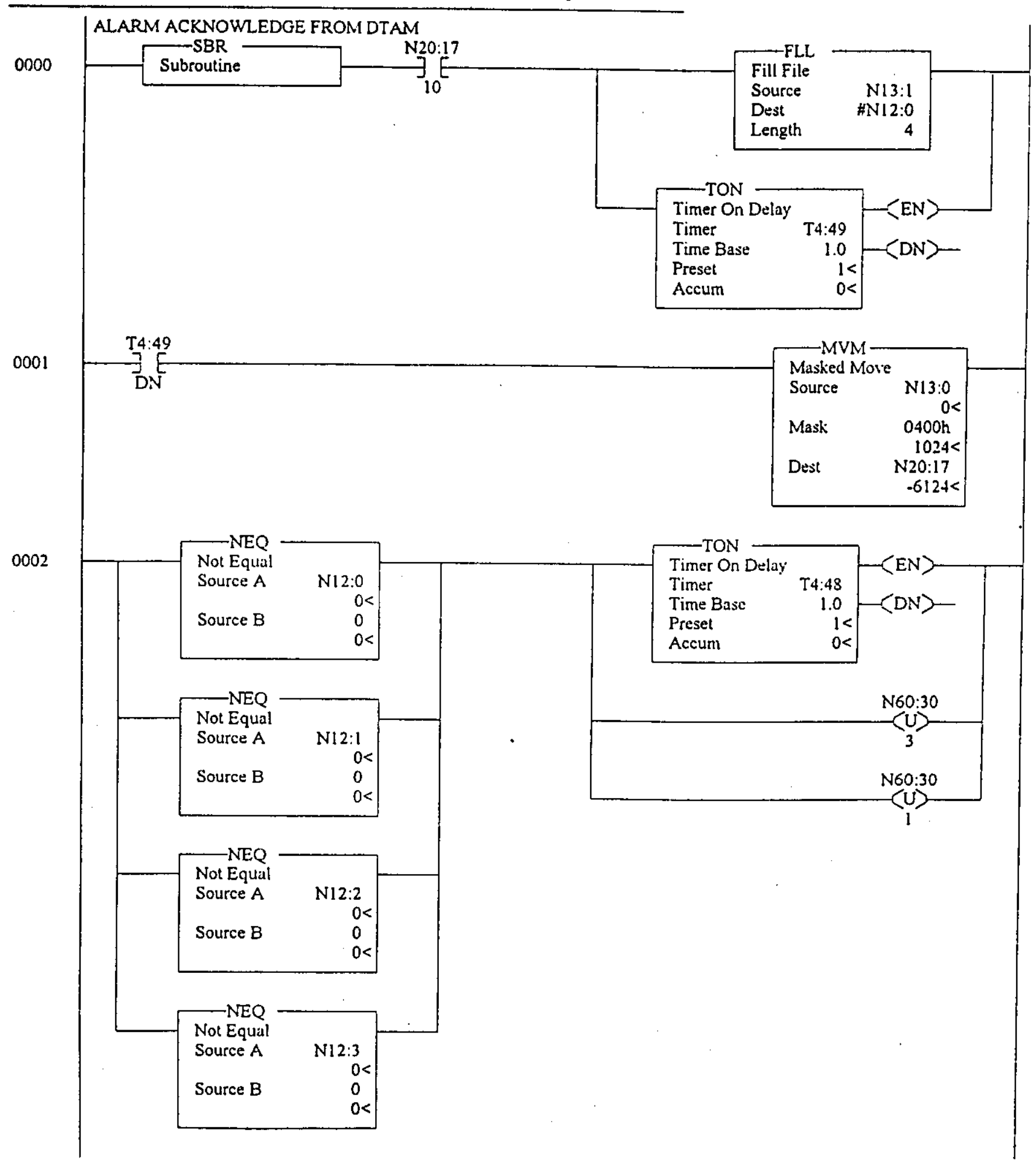


U103last.rss

LAD 8 - -- Total Rungs in File $=6$

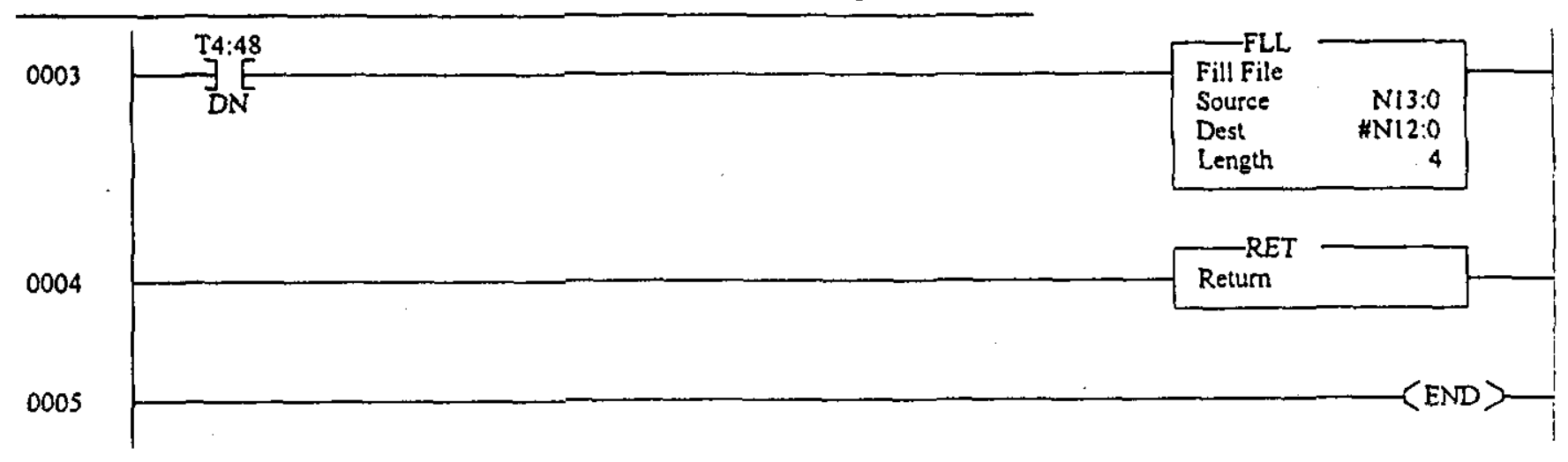


LAD 9 - ... Total Rungs in File $=6$

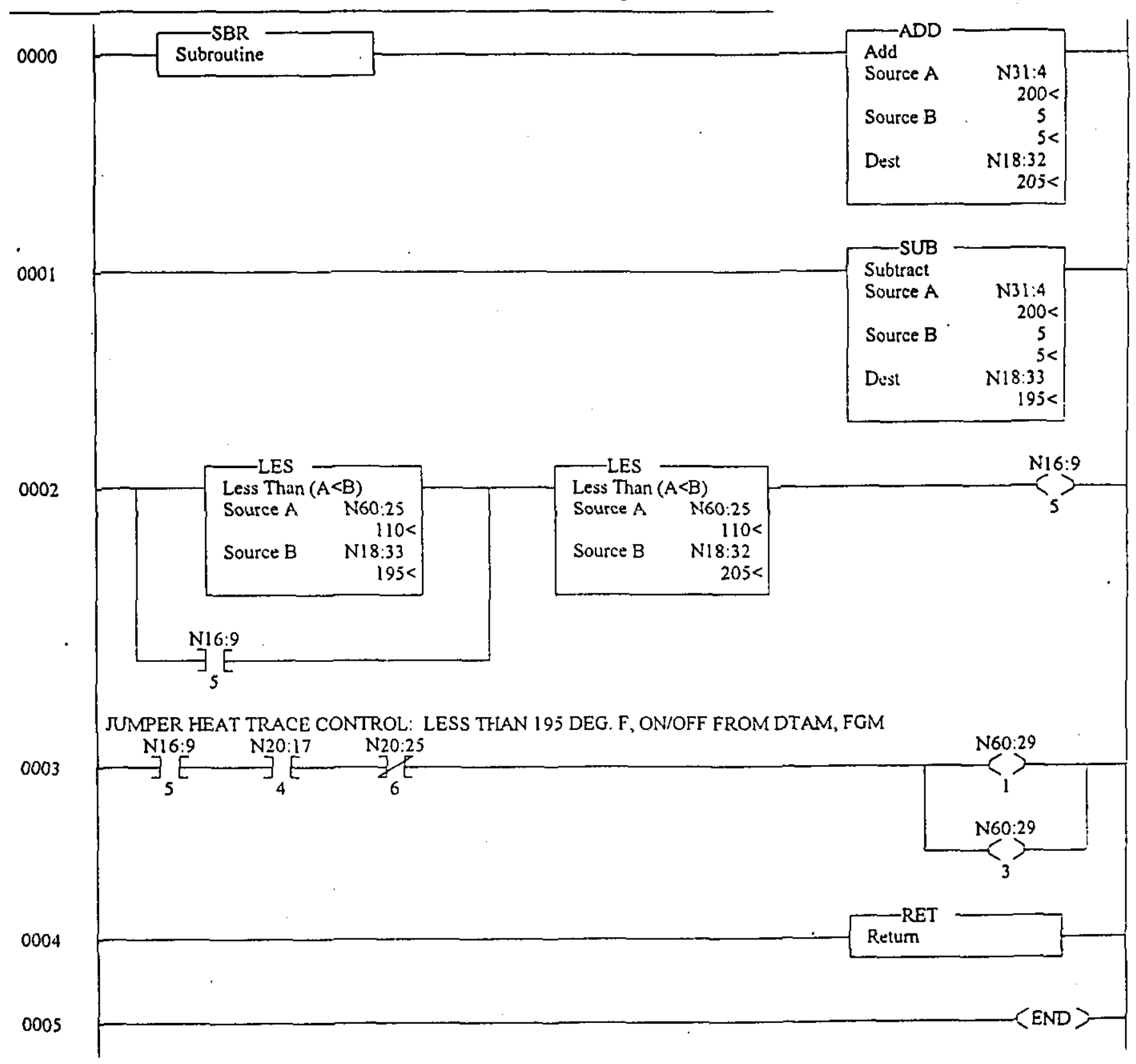


U103 last.rss

LAD 10 - - Total Rungs in File $=11$

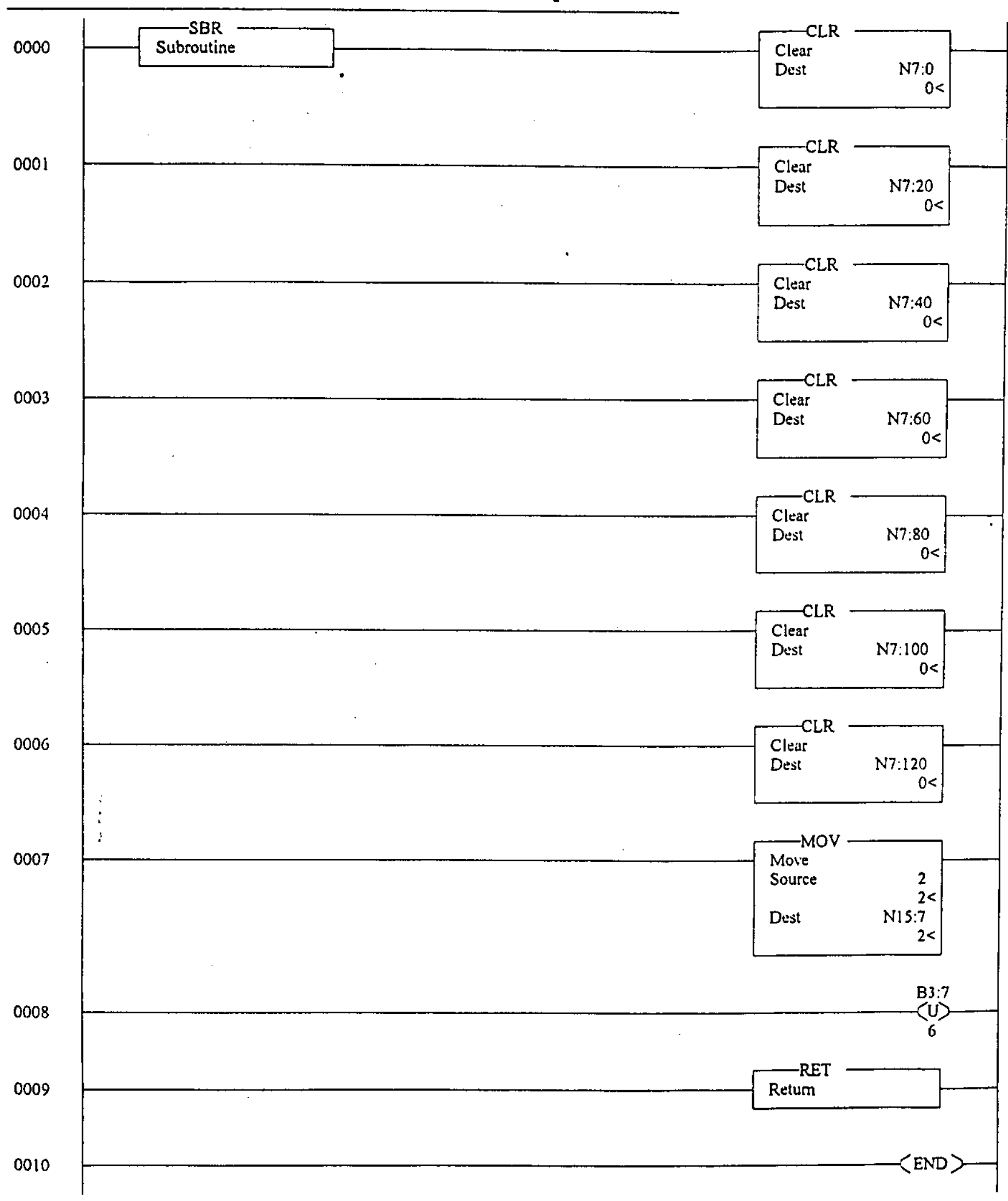

Puge 1 - 1

Monduy, September 27, 1999 - 08:16:19 
U103last.rss

LAD 11 - - Total Rungs in File $=3$

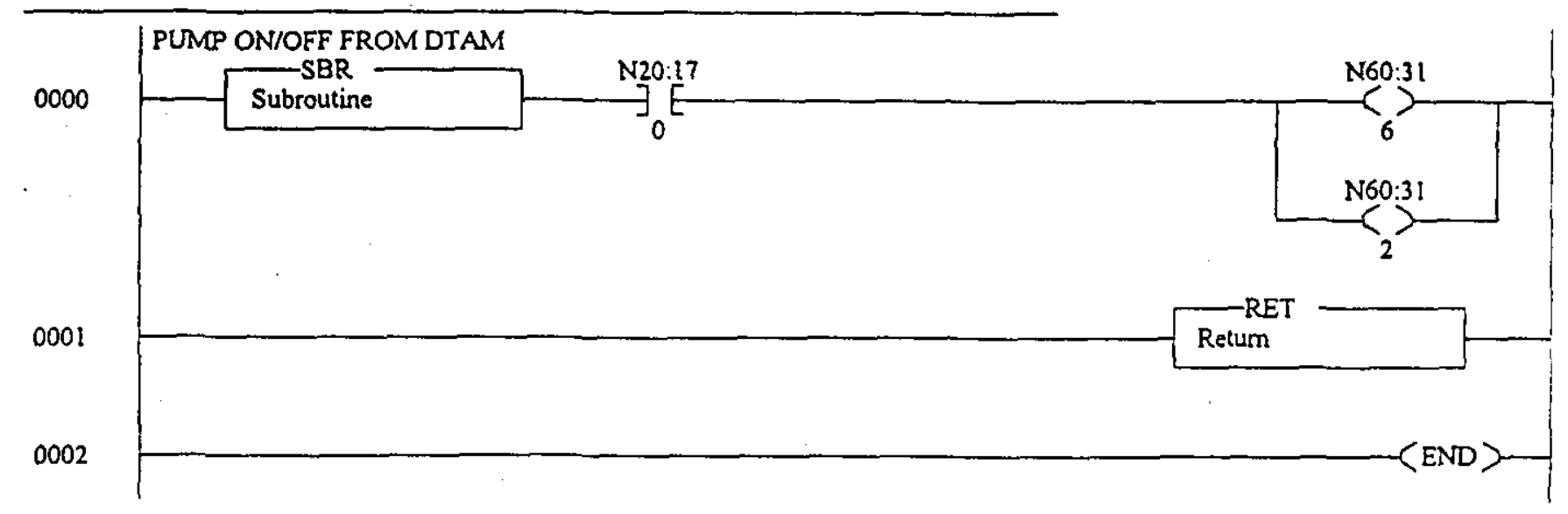


LAD 12 - - Total Rungs in File $=10$

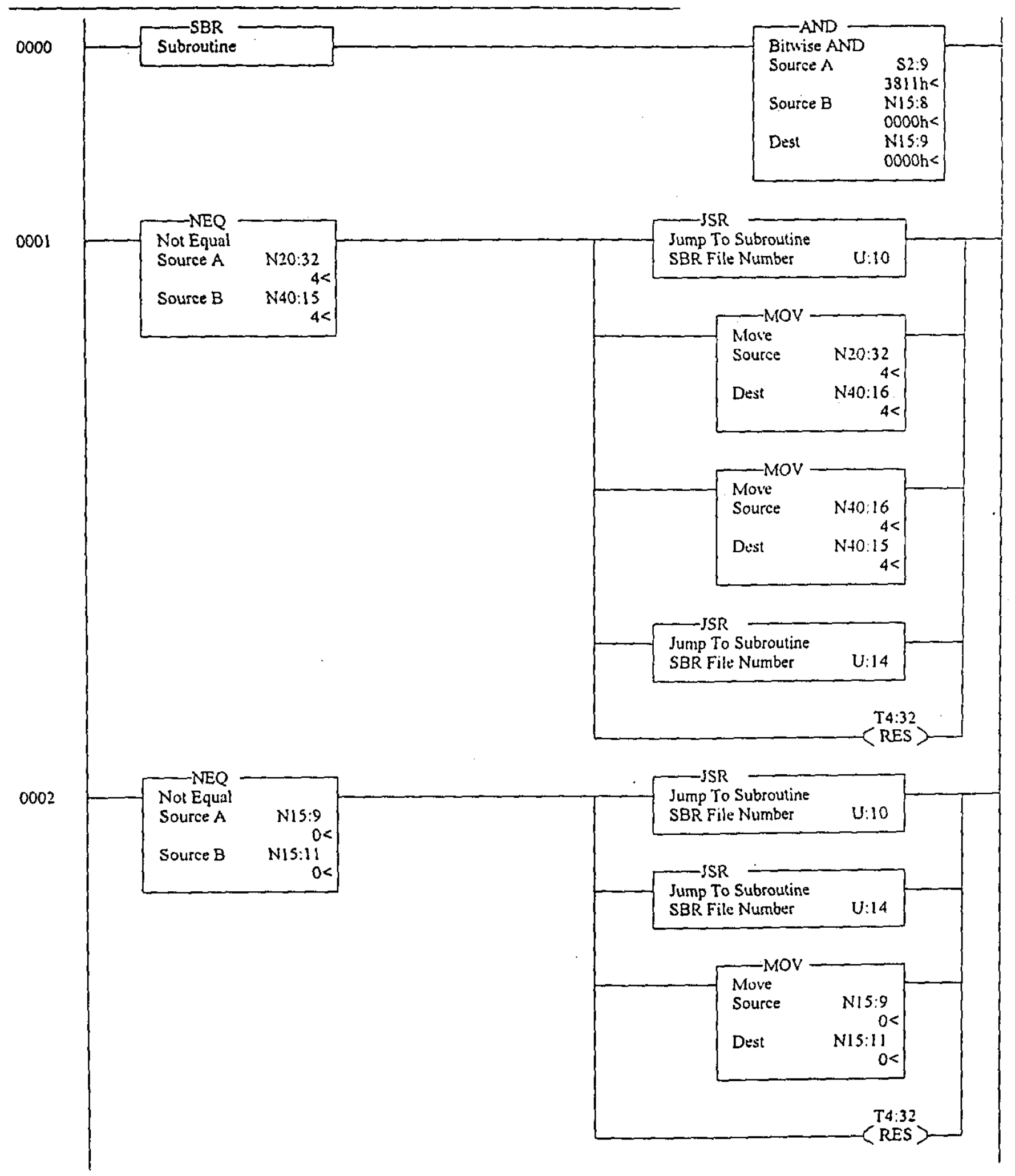

Page 1 - 1 
LAD 12 - .. Total Rungs in File $=10$

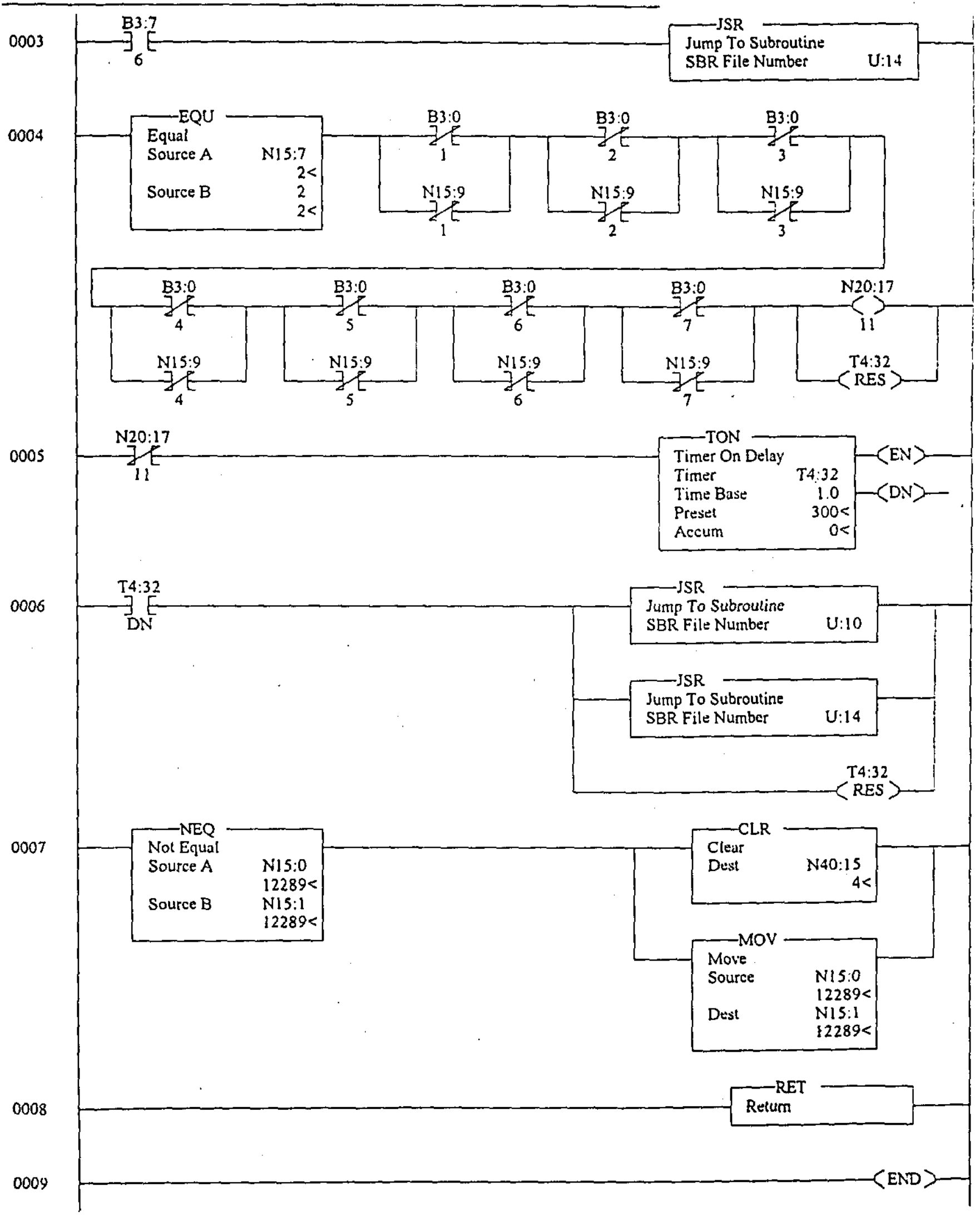

Puge i - 2

Monday, Seplember 27, 1999 - 08:16:20 
LAD $13 \ldots$ Total Rungs in File $=6$

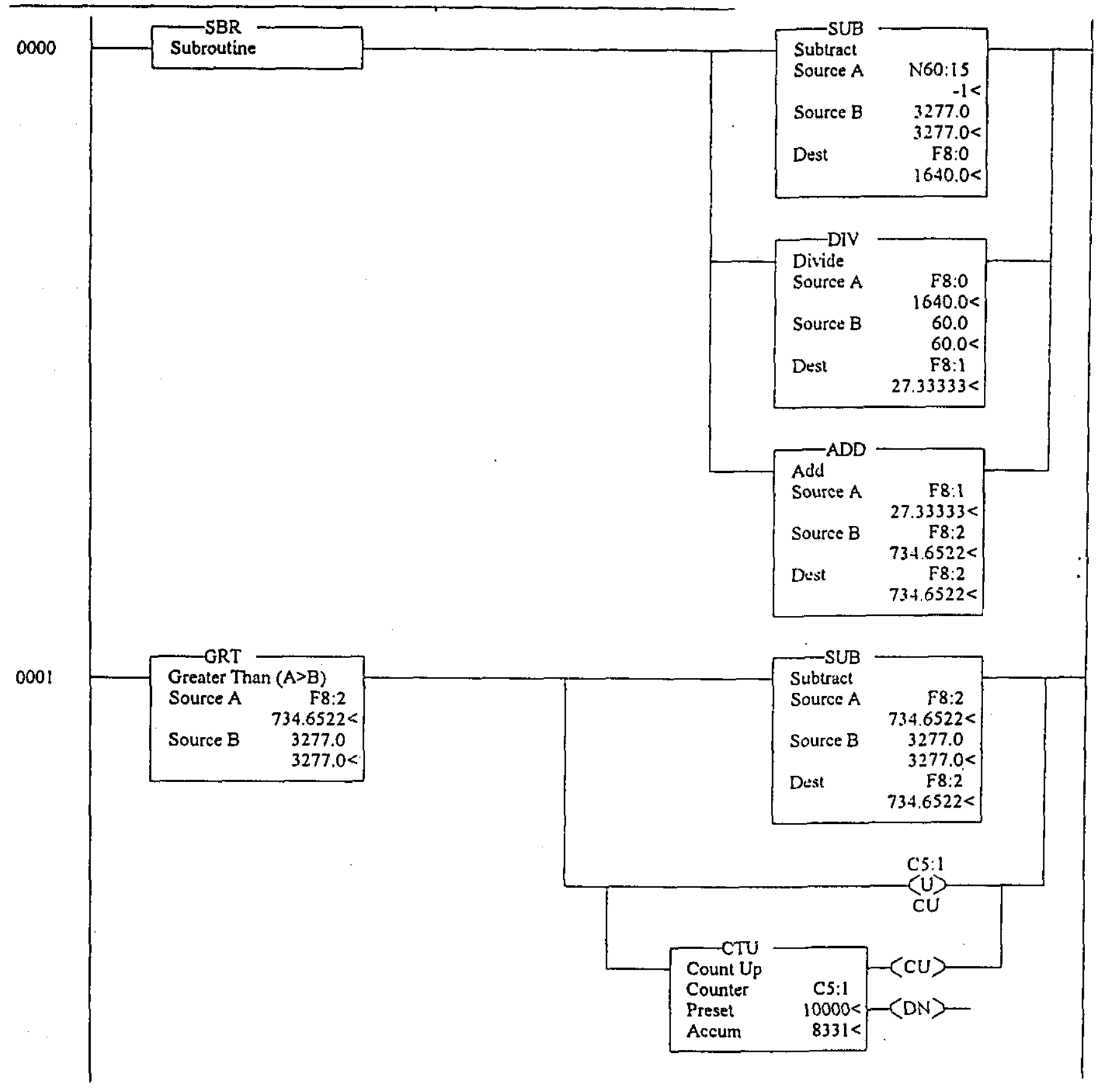




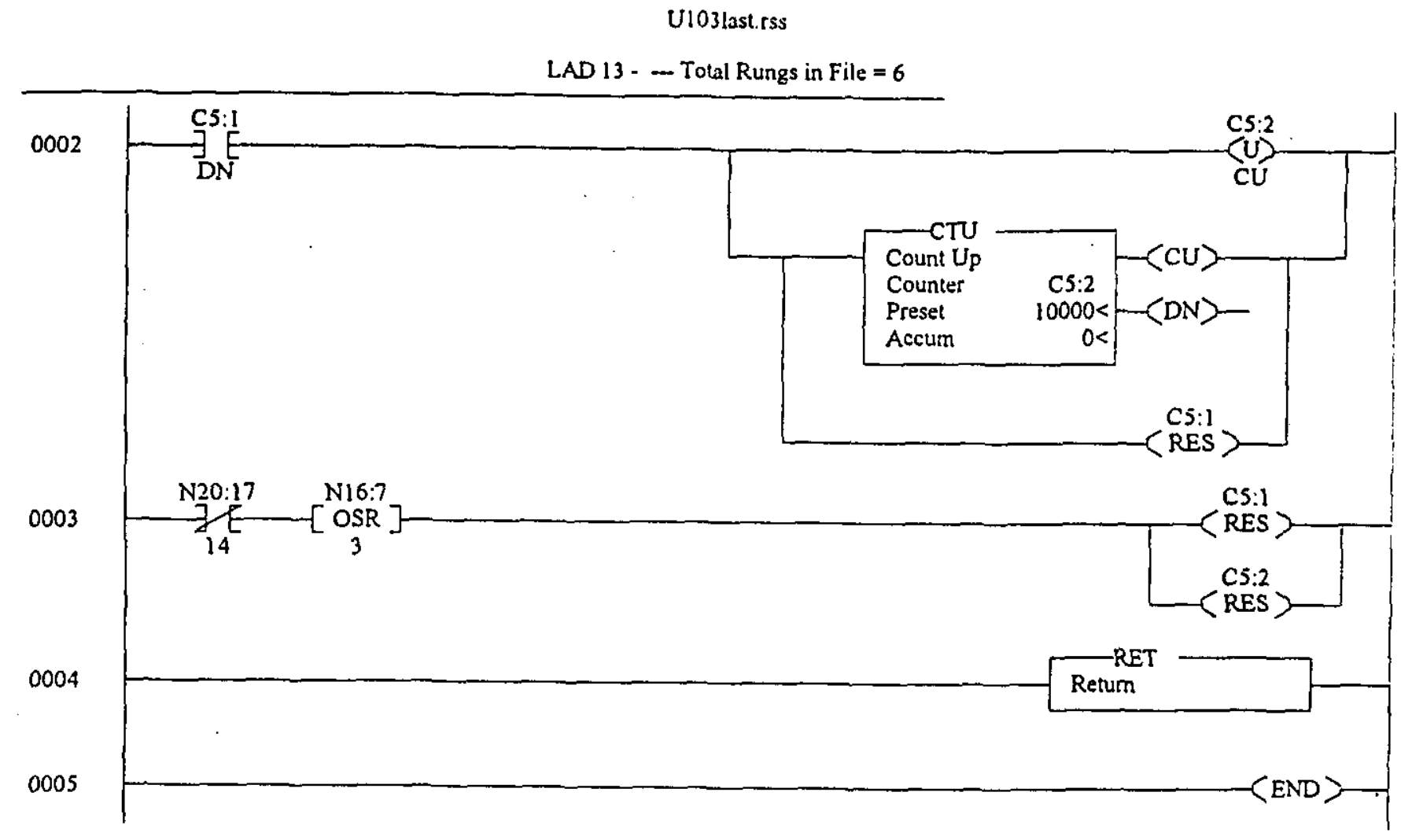


LAD 14 - - Total Rungs in File $=11$

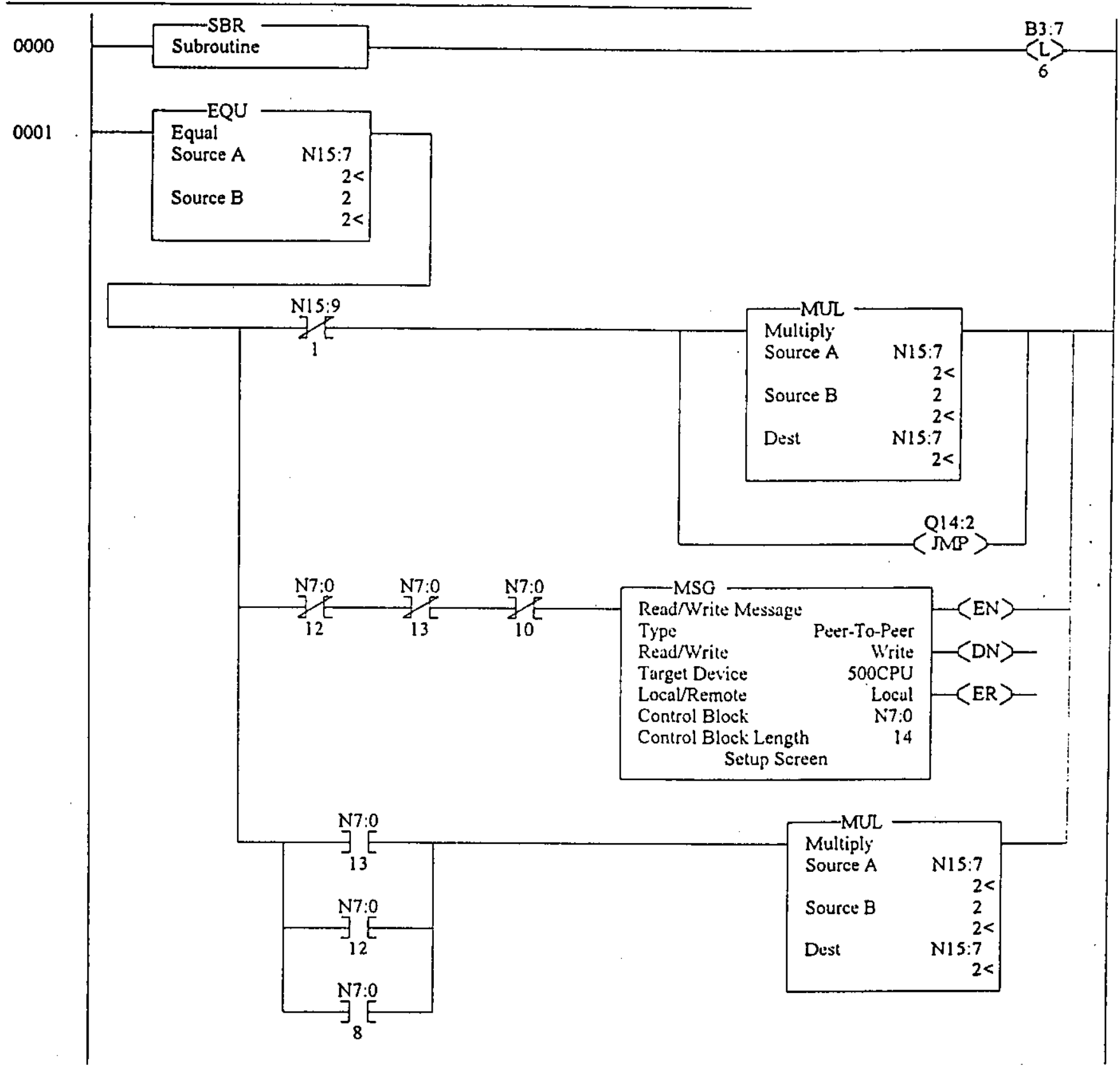


U103last.rss

LAD 14 - ..- Total Rungs in File $=11$

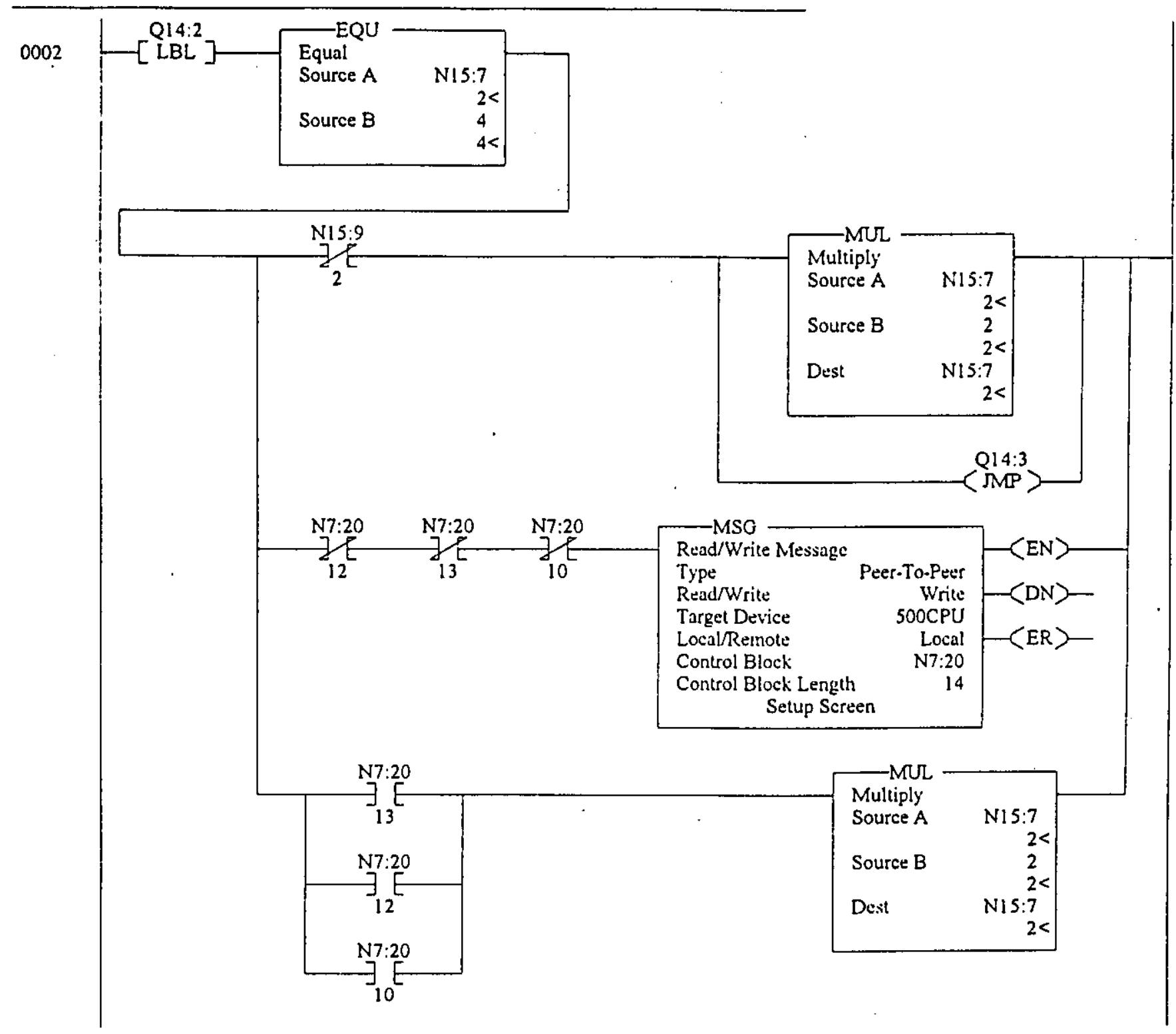


LAD 14 - Total Rungs in File $=11$

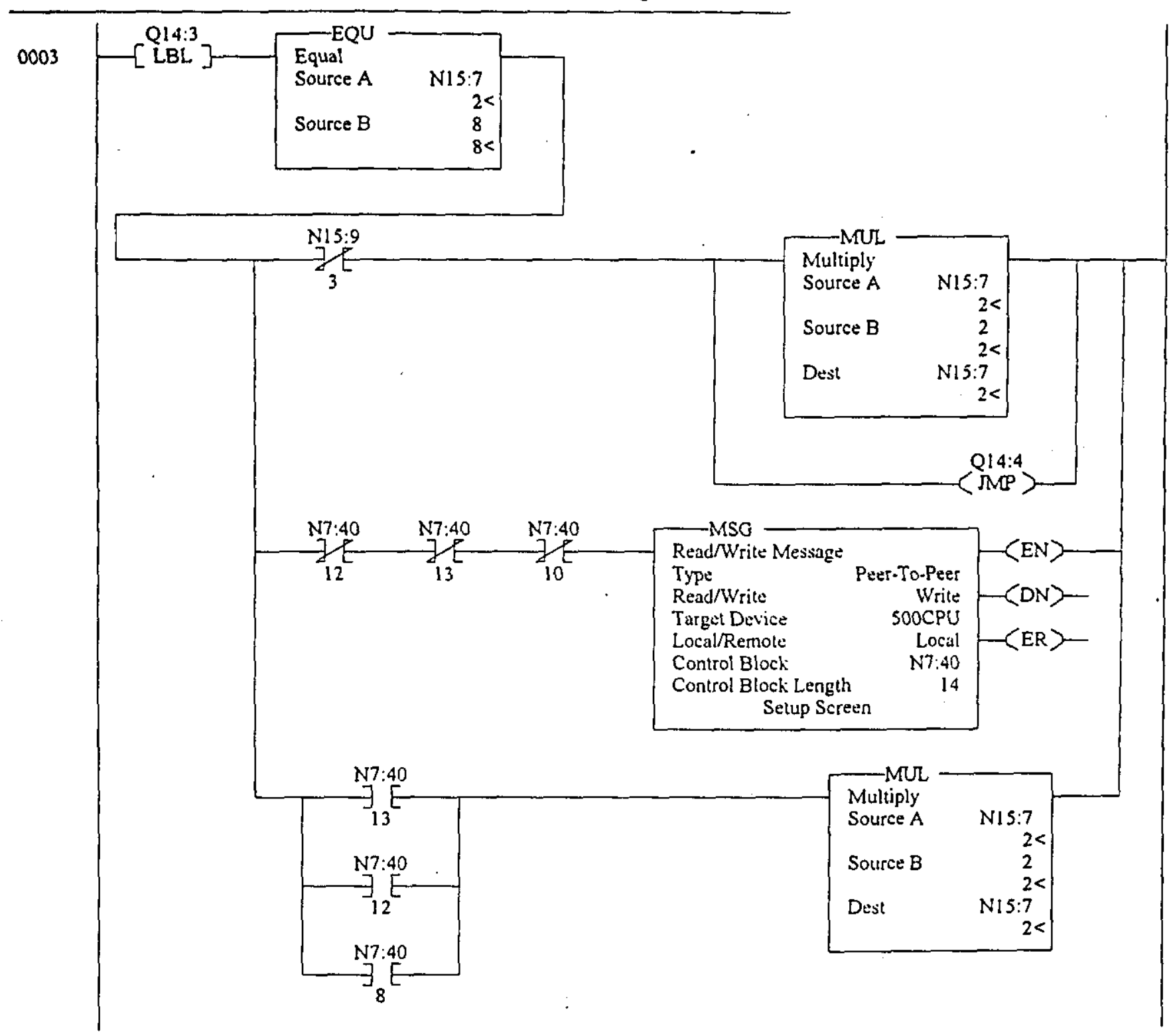




\section{U103last.rss}

LAD 14 - .-- Total Rungs in File $=11$

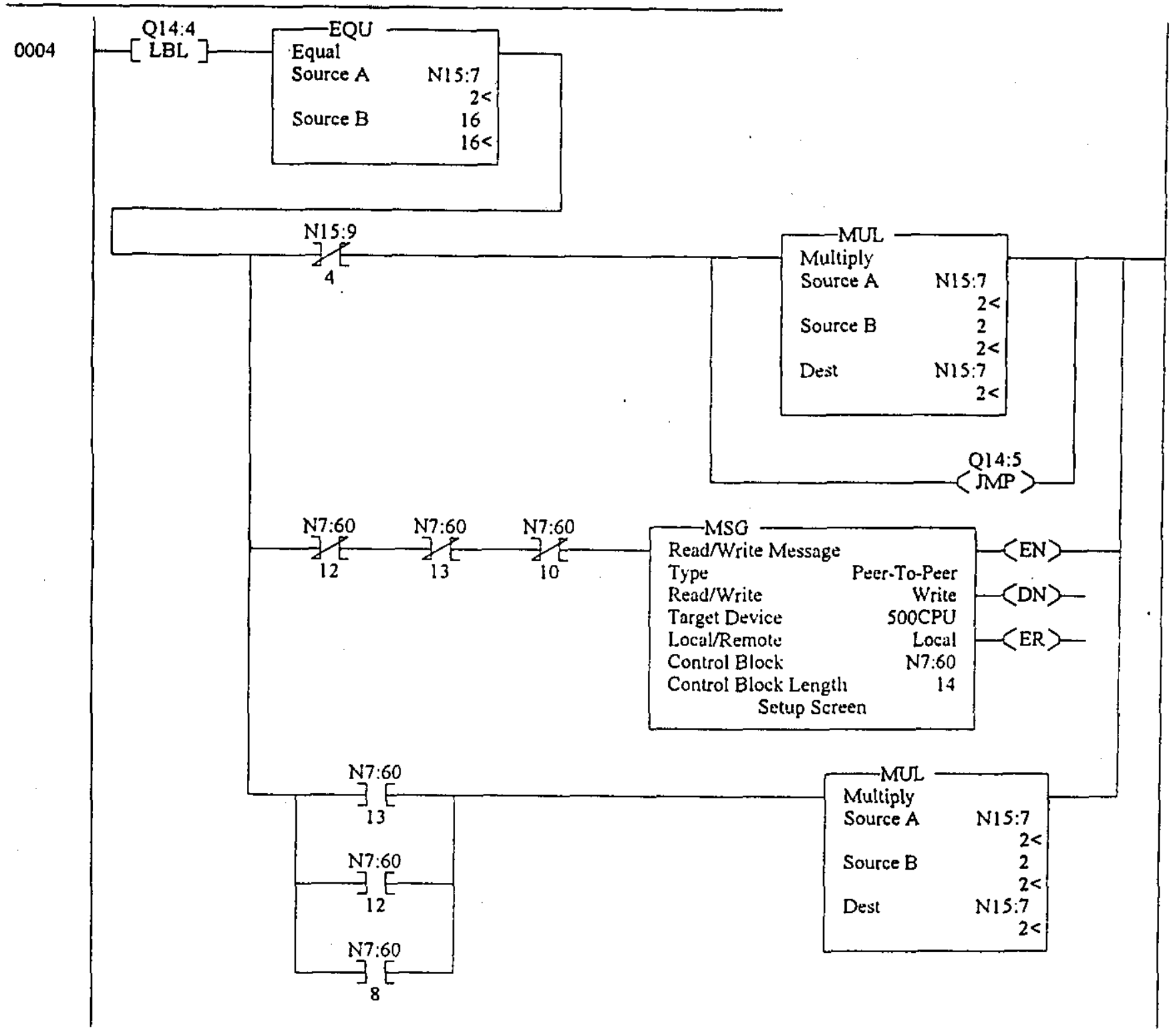


U103last.tss

LAD 14 ...- Total Rungs in File $=11$

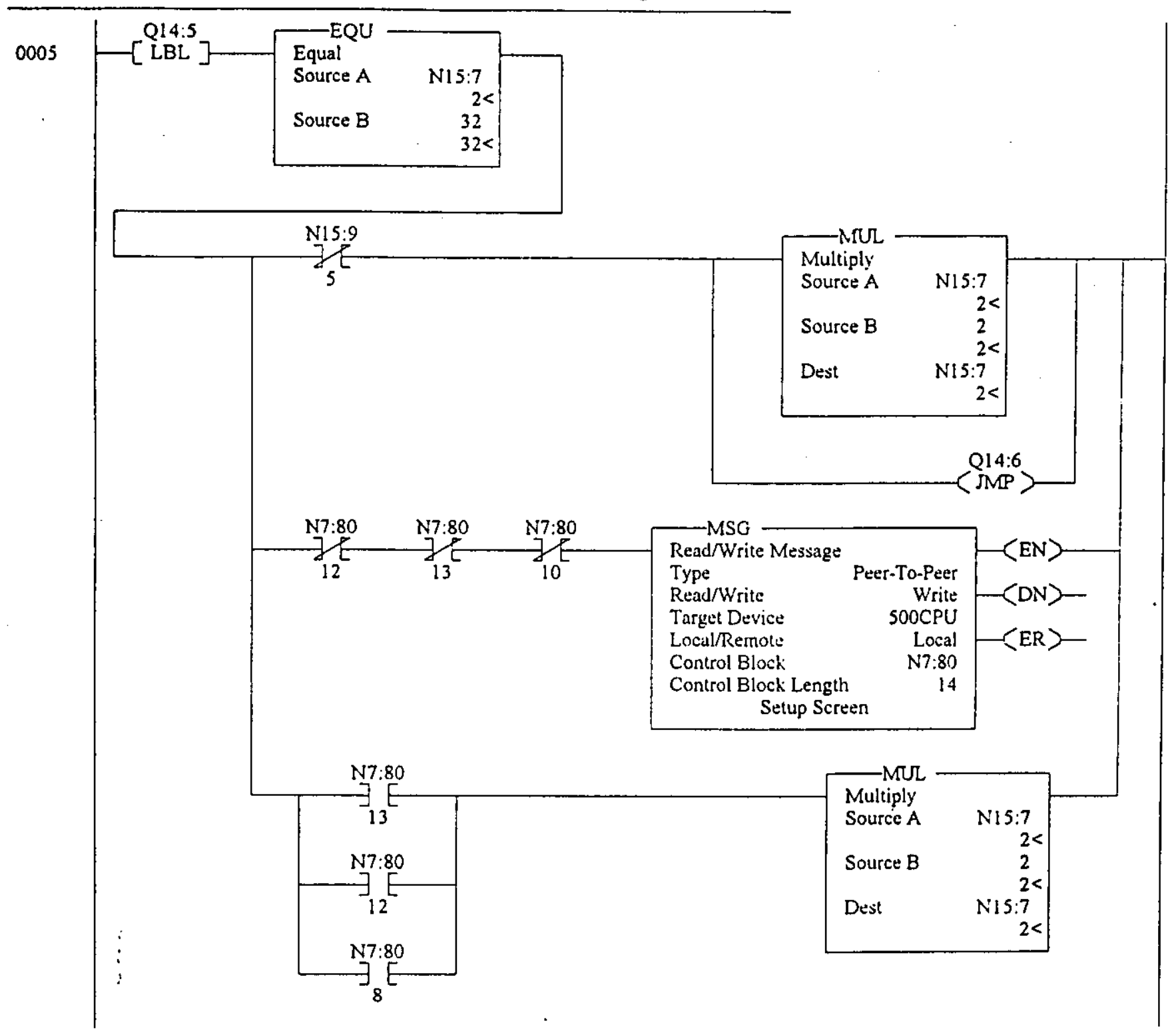


U103last.rss

LAD 14 - .- Total Rungs in File $=11$

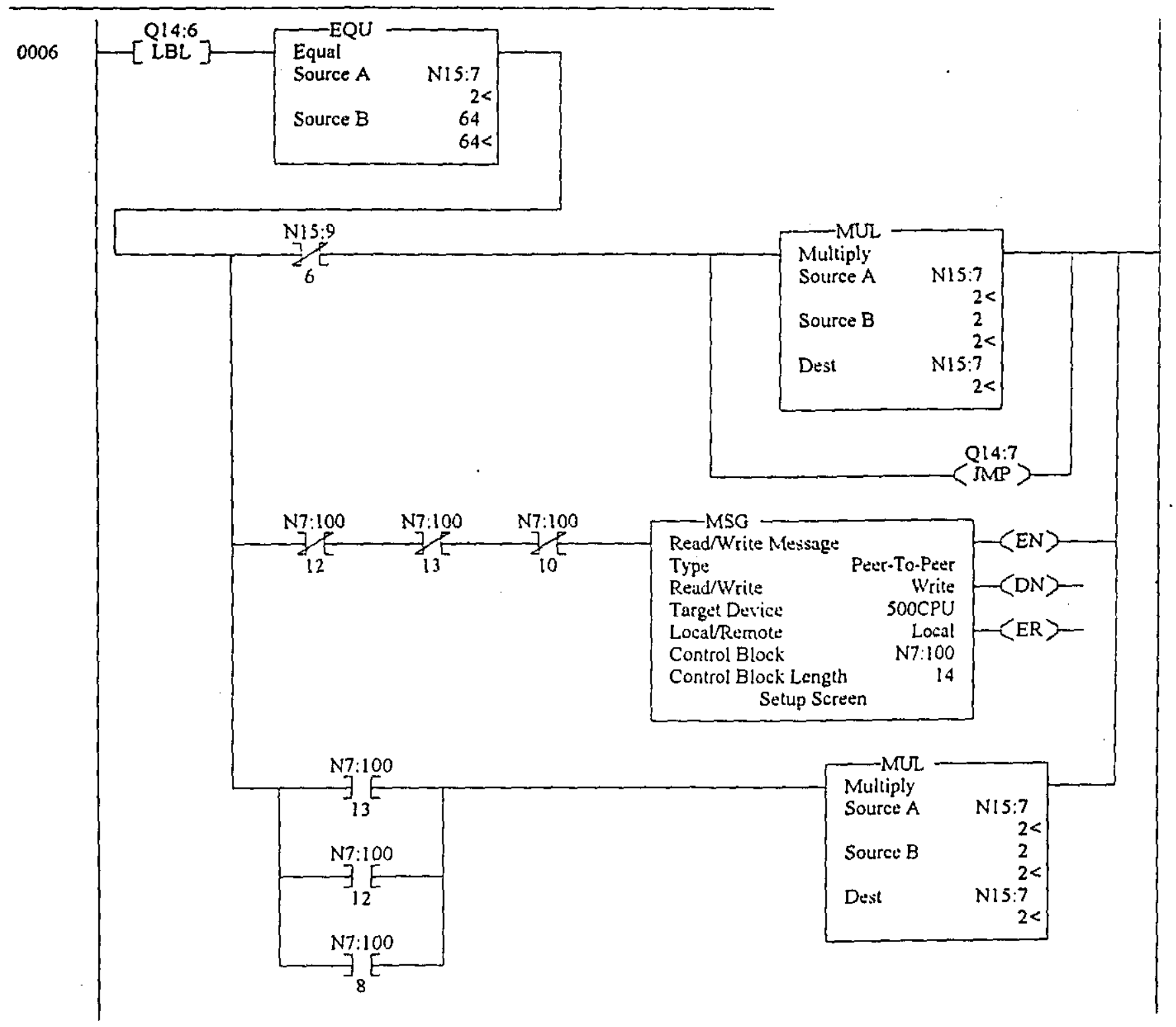


U103 last.rss

LAD 14 - - Total Rungs in File $=11$

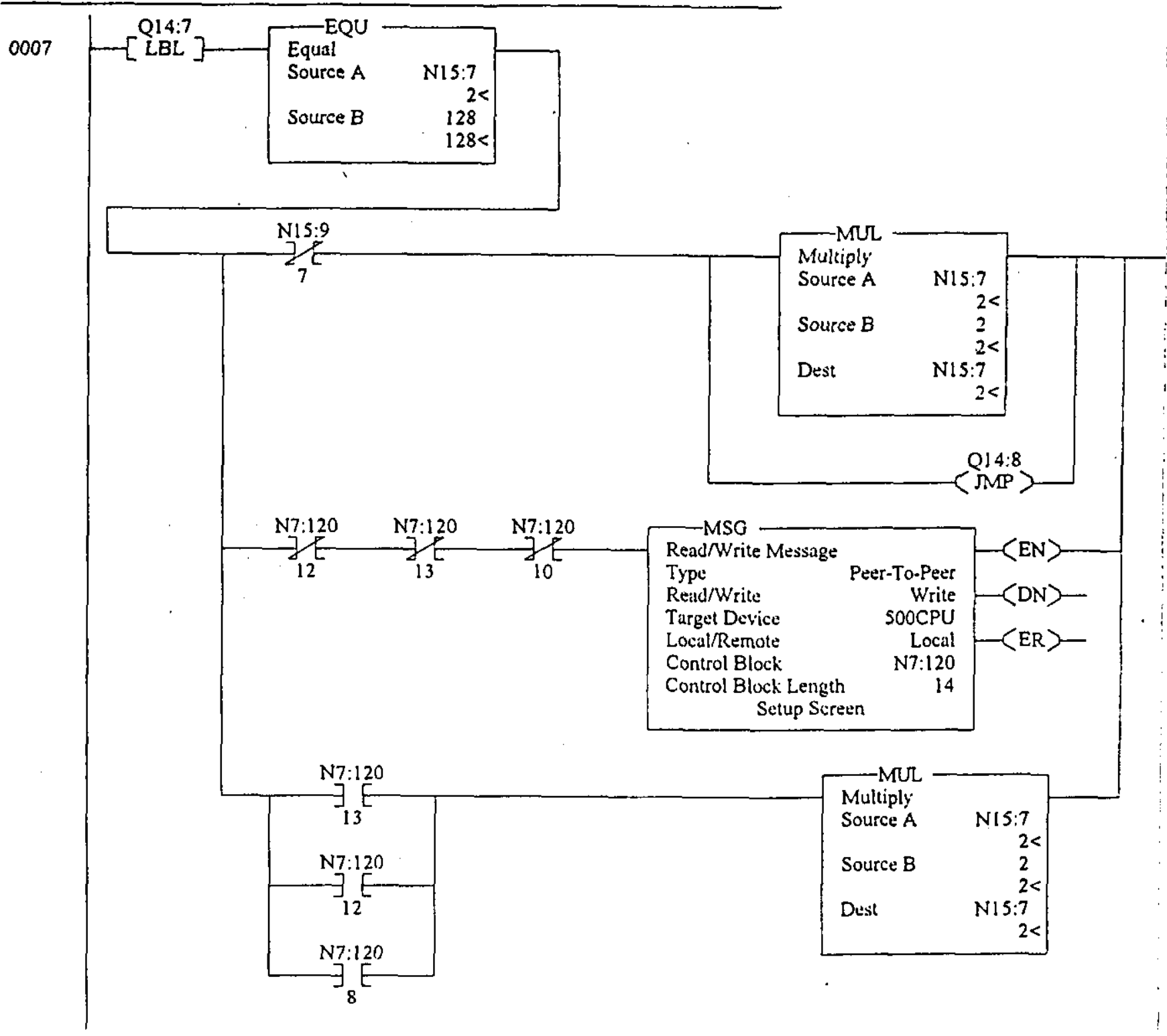

Page 1 - 7

Monduy, September 27, $1999-08: 16: 21$ 
U103last.rss

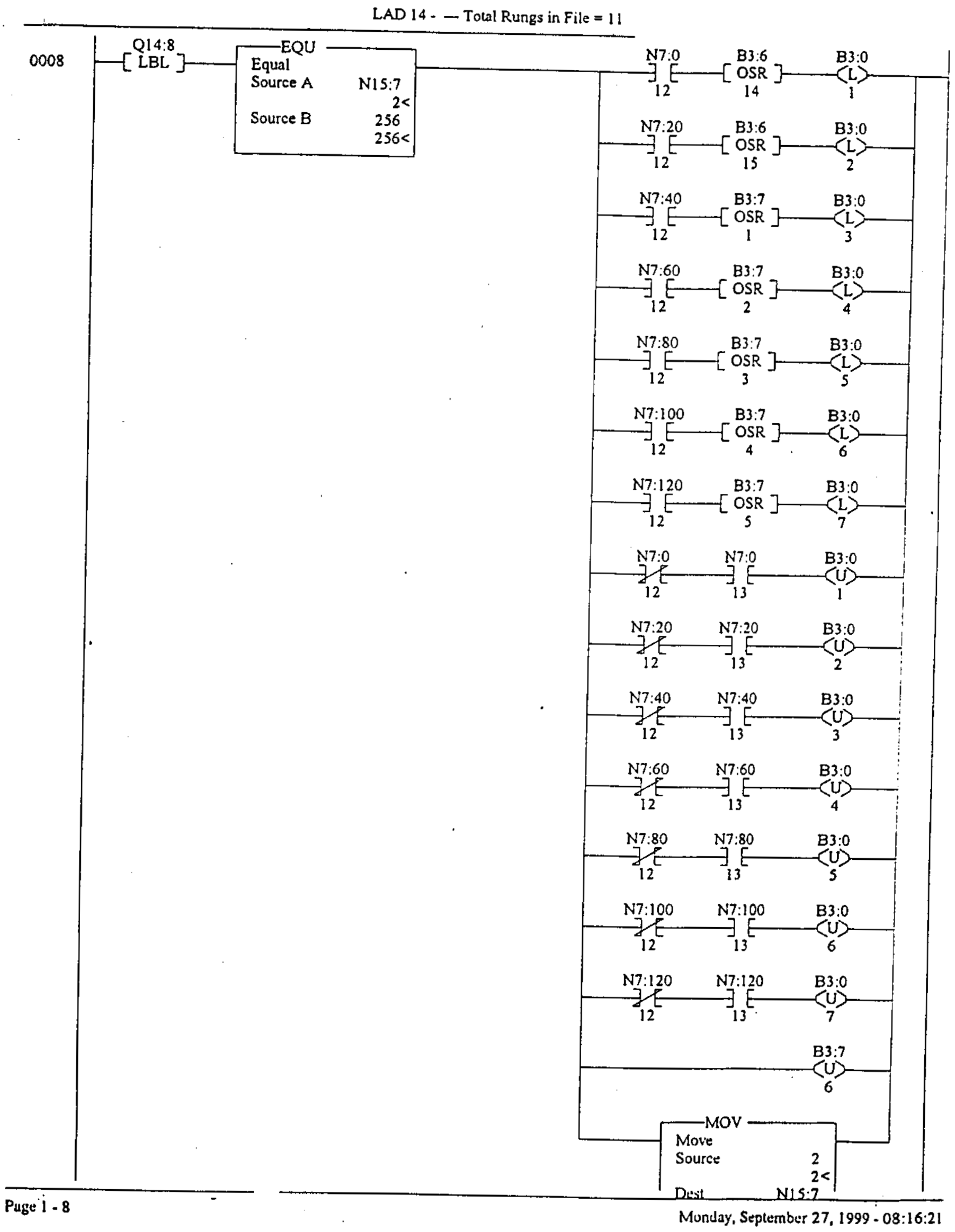




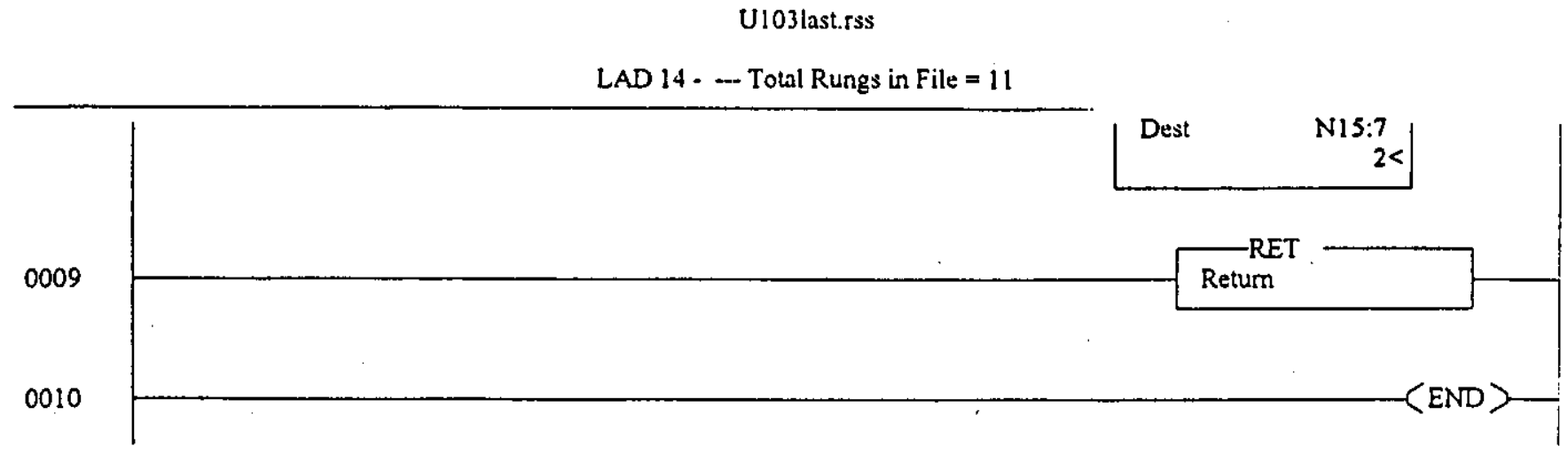


LAD 15 - ..- Total Rungs in File $=16$

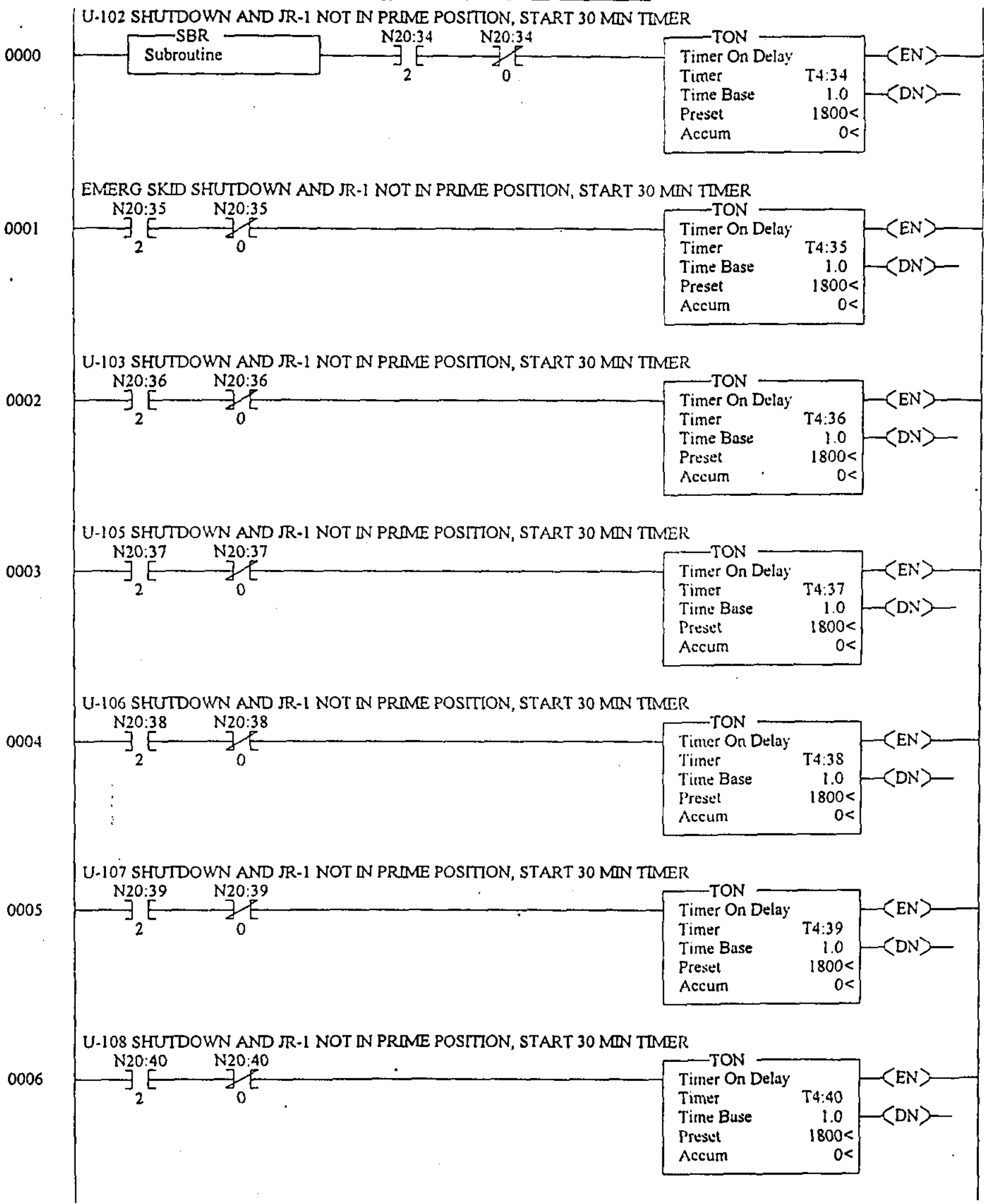


LAD 15.-- Total Rungs in File $=16$

0007

U-109 SHUTDOWN AND JR-! NOT IN PRIME POSTTON, START 30 MIN TTMER

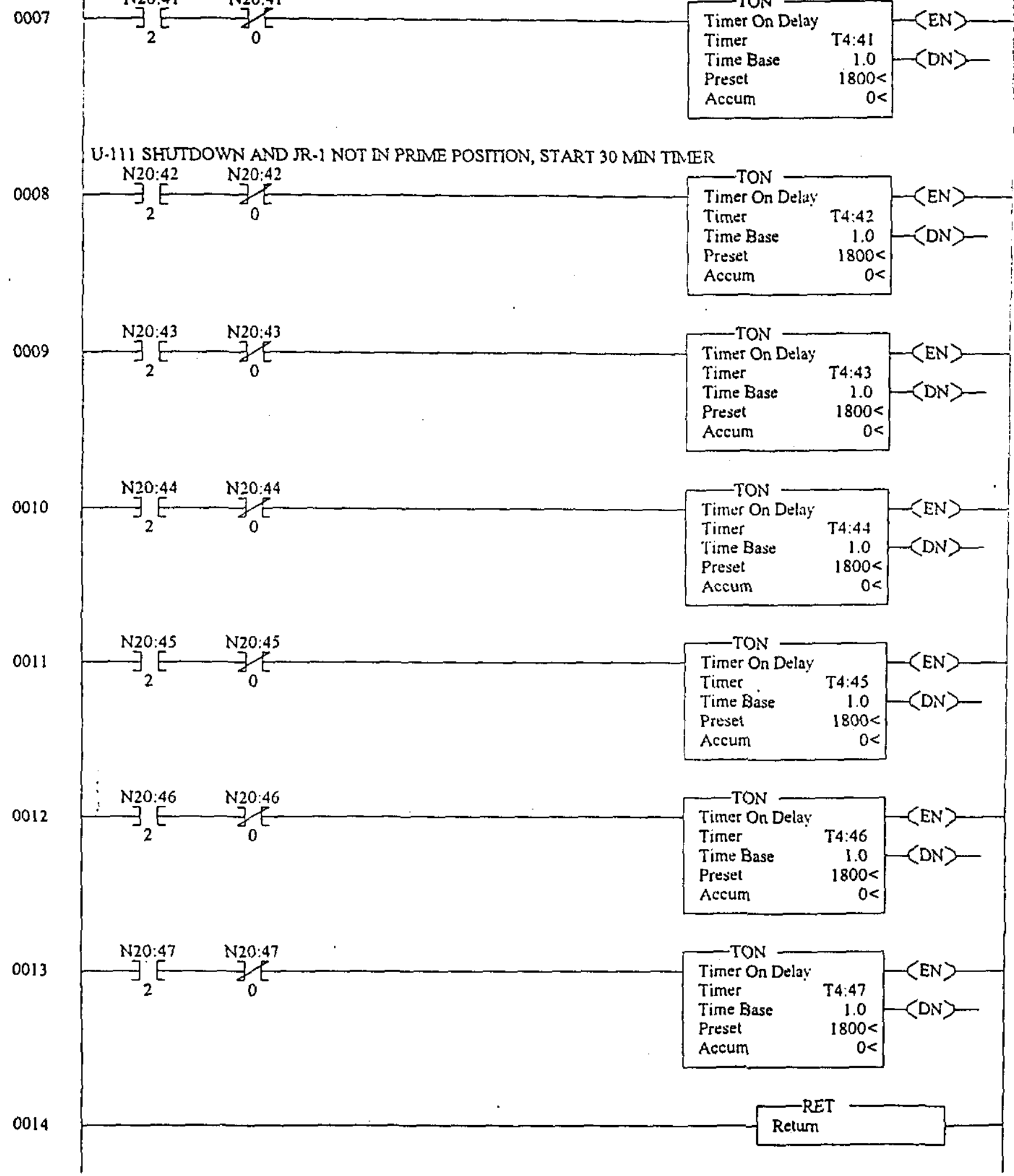


U103 last.rss

LAD 15 - Total Rungs in File $=16$

0015

(END)

Puge 1 - 3

Wednesday, September 29, 1999 - 14:29:50

HNF-5820, Rev. 0

B-57

$=-\cdots$

APPENDIX B 
Ul03last.rss

LAD 16 - - Total Rungs in File $=6$

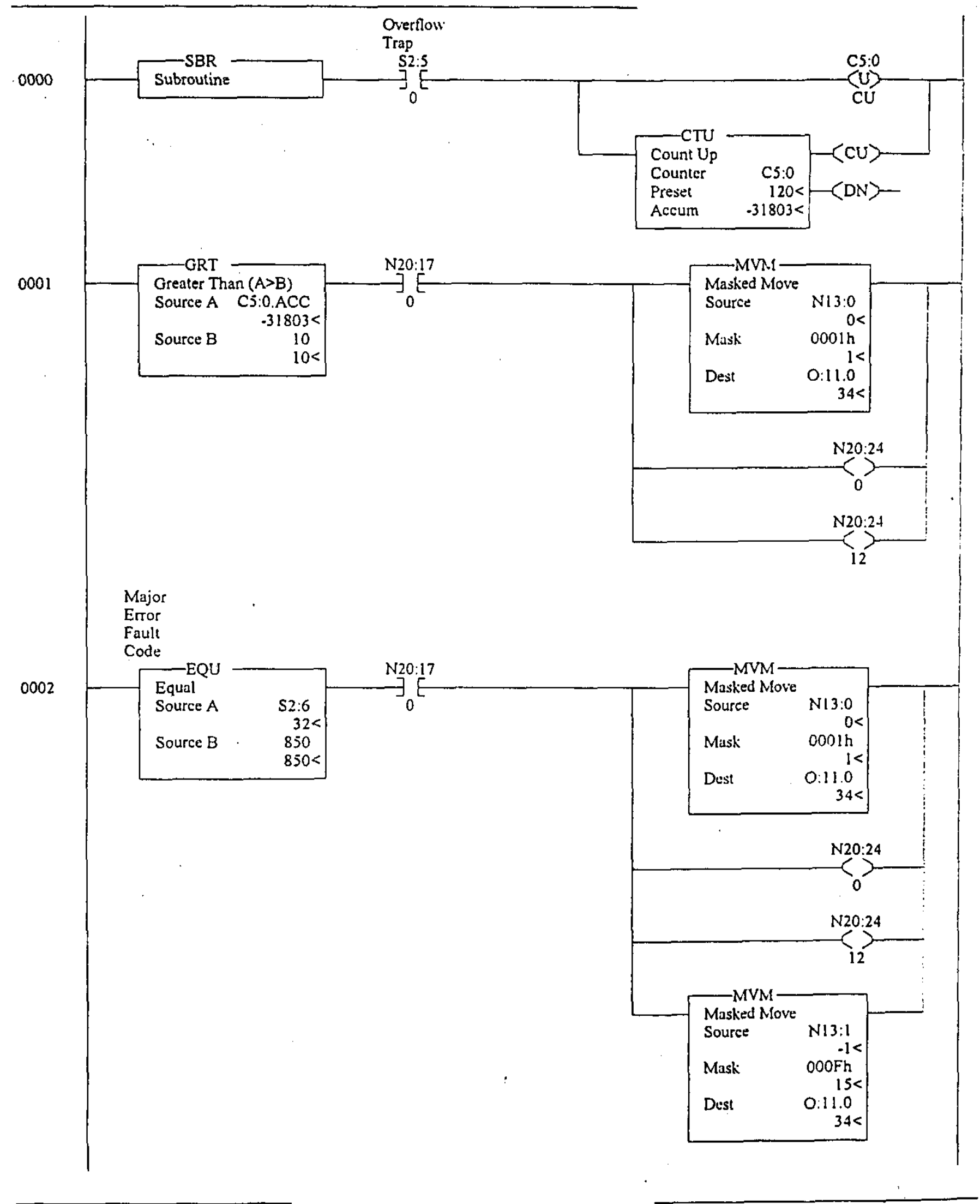

Page 1 - 1

Monduy, September 27, 1999 - 08:16:22 


\section{U103last.rss}

LAD 16 - - Total Rungs in File $=6$

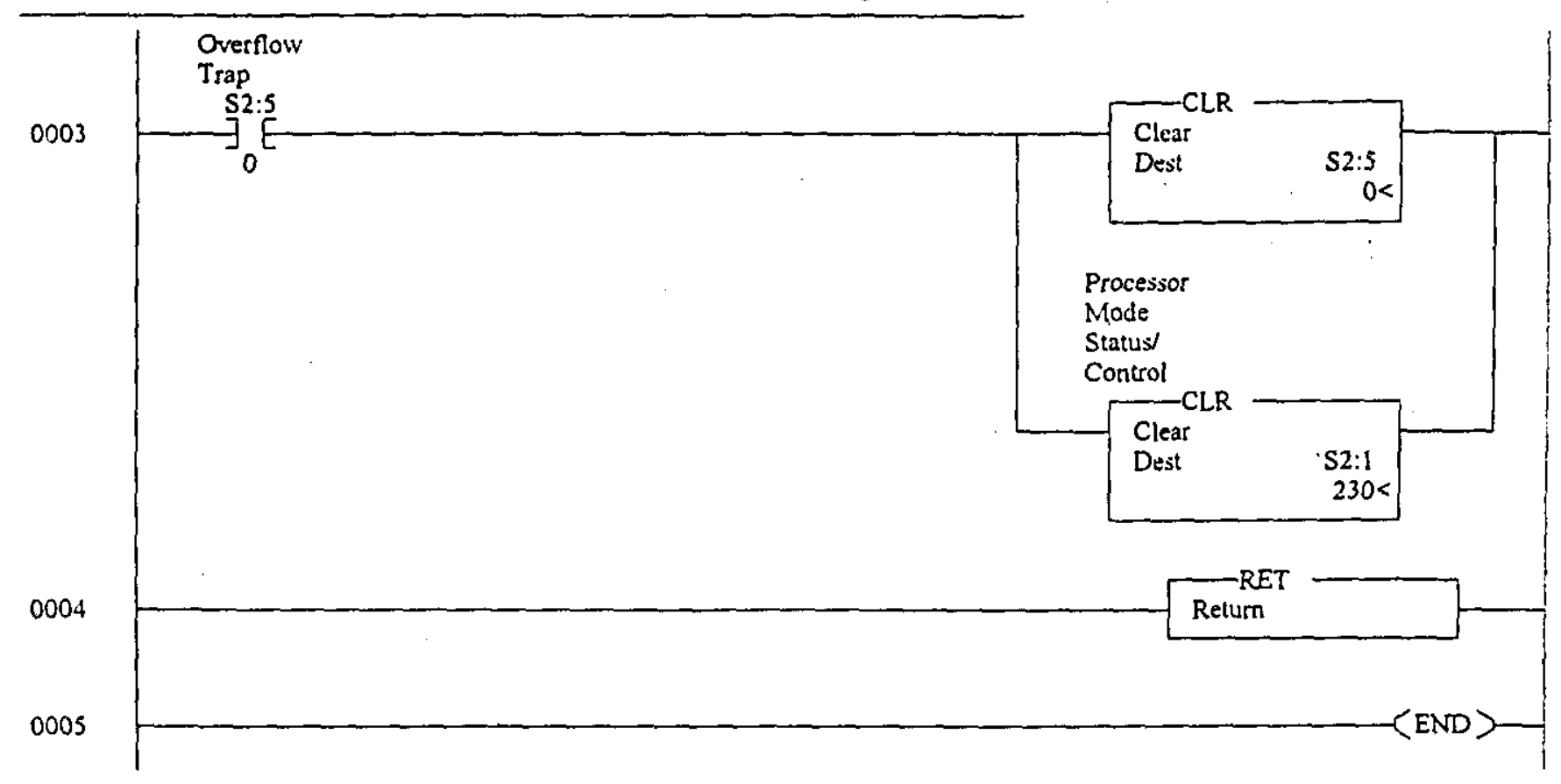




\section{U103last.rss}

LAD 17 - Total Rungs in File $=65$

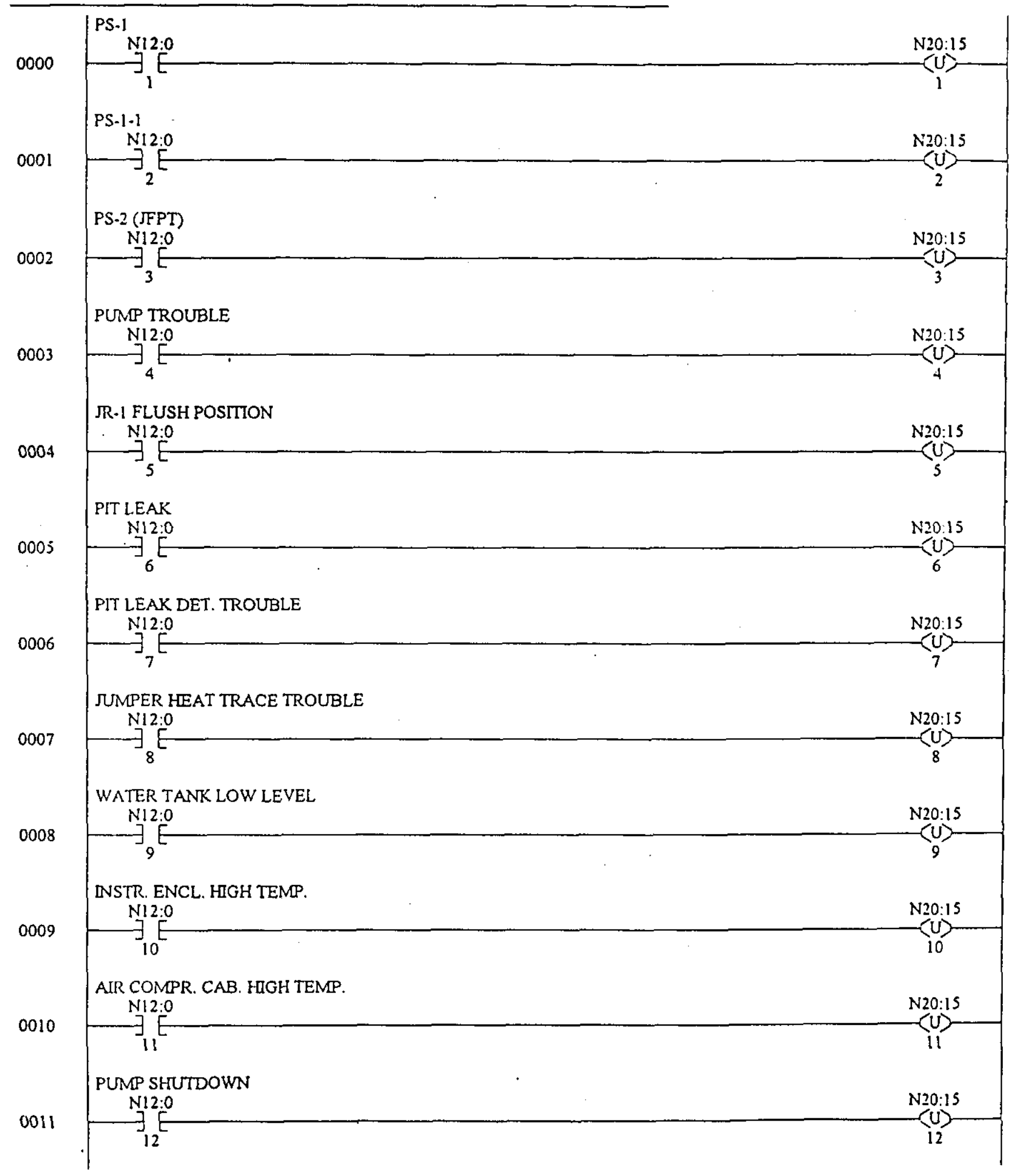




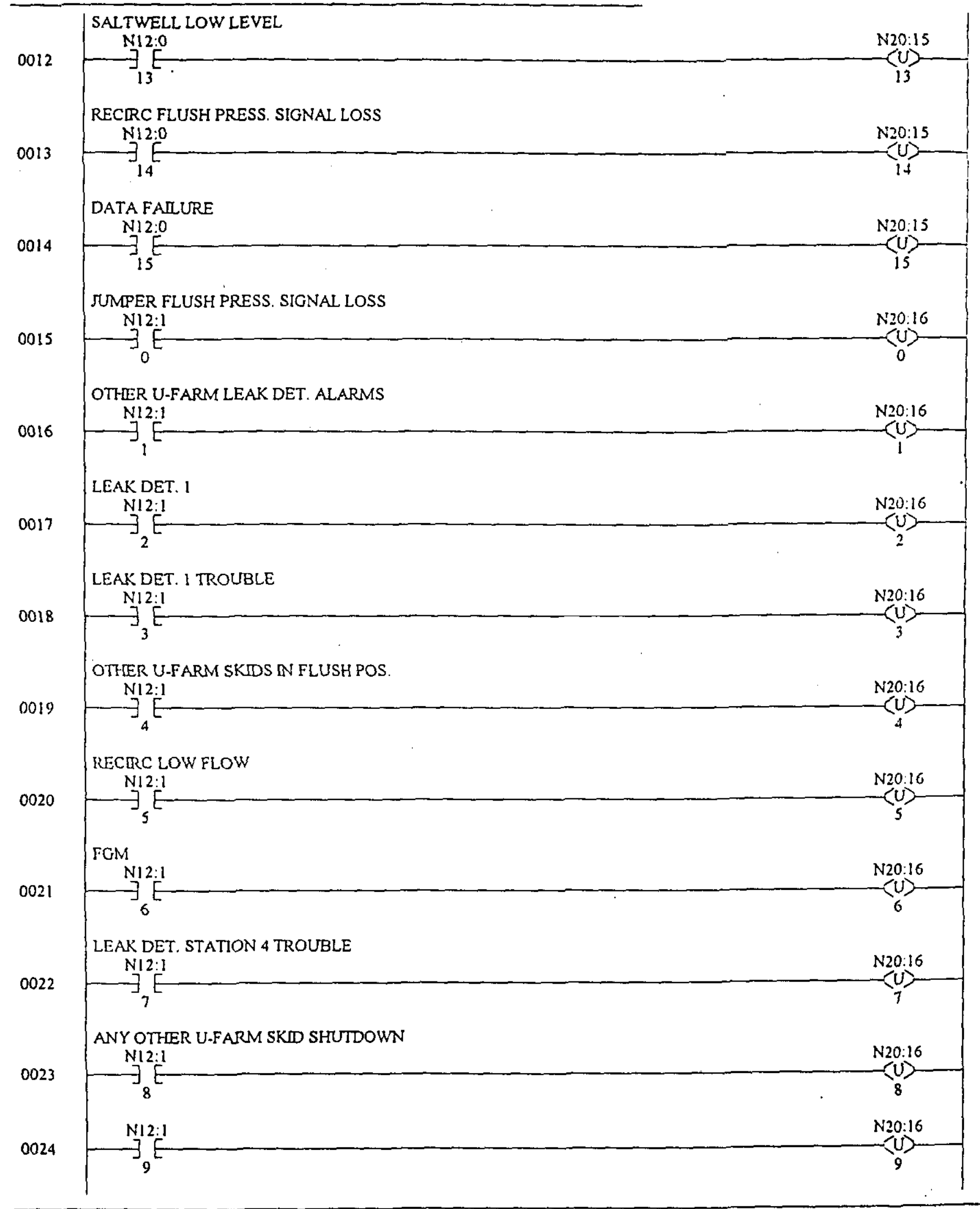

Page 1.2 
U103last.rss

LAD 17 - - Total Rungs in File $=65$

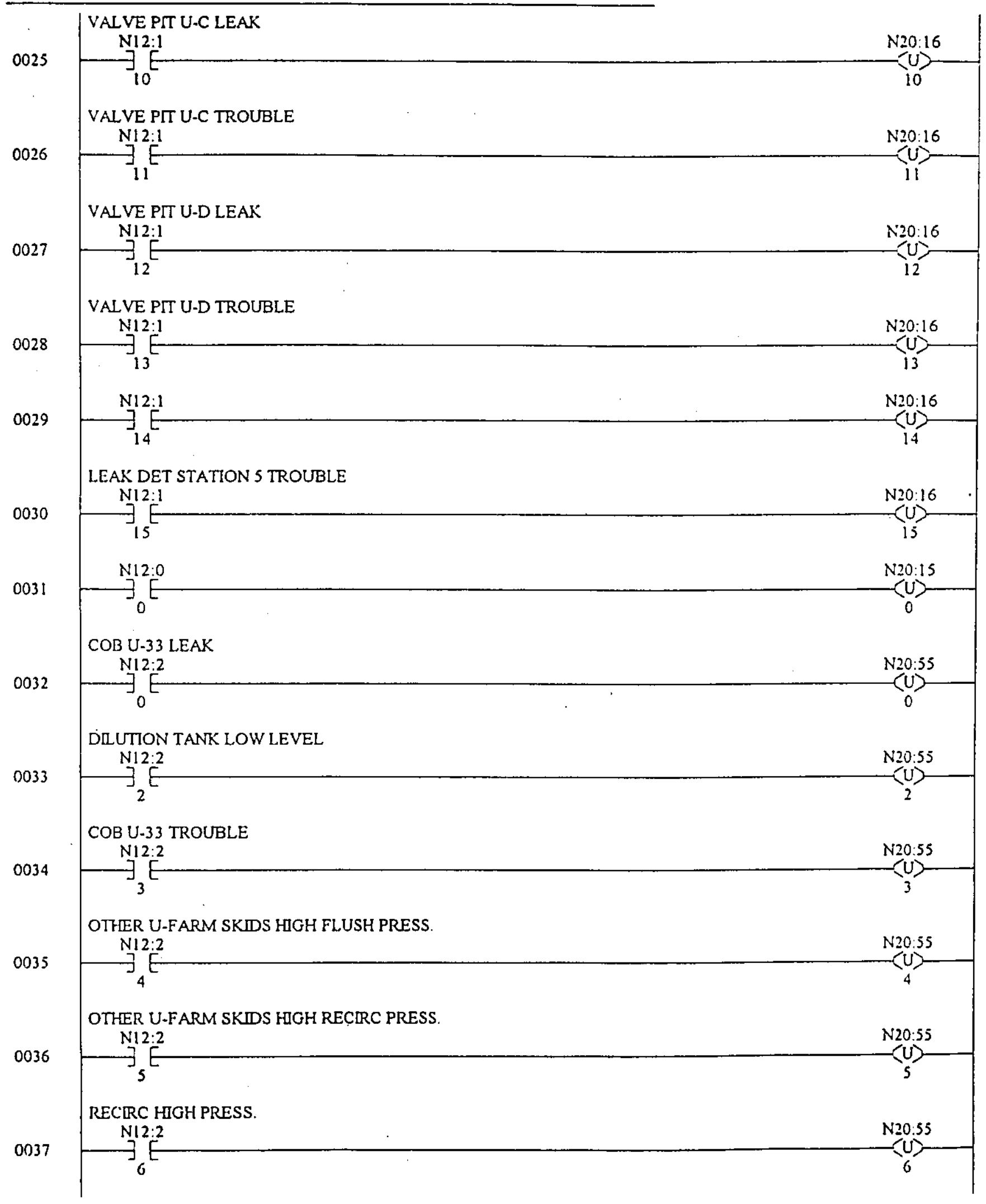

Puge 1 - 3 
LAD 17 - -- Total Rungs in File $=65$

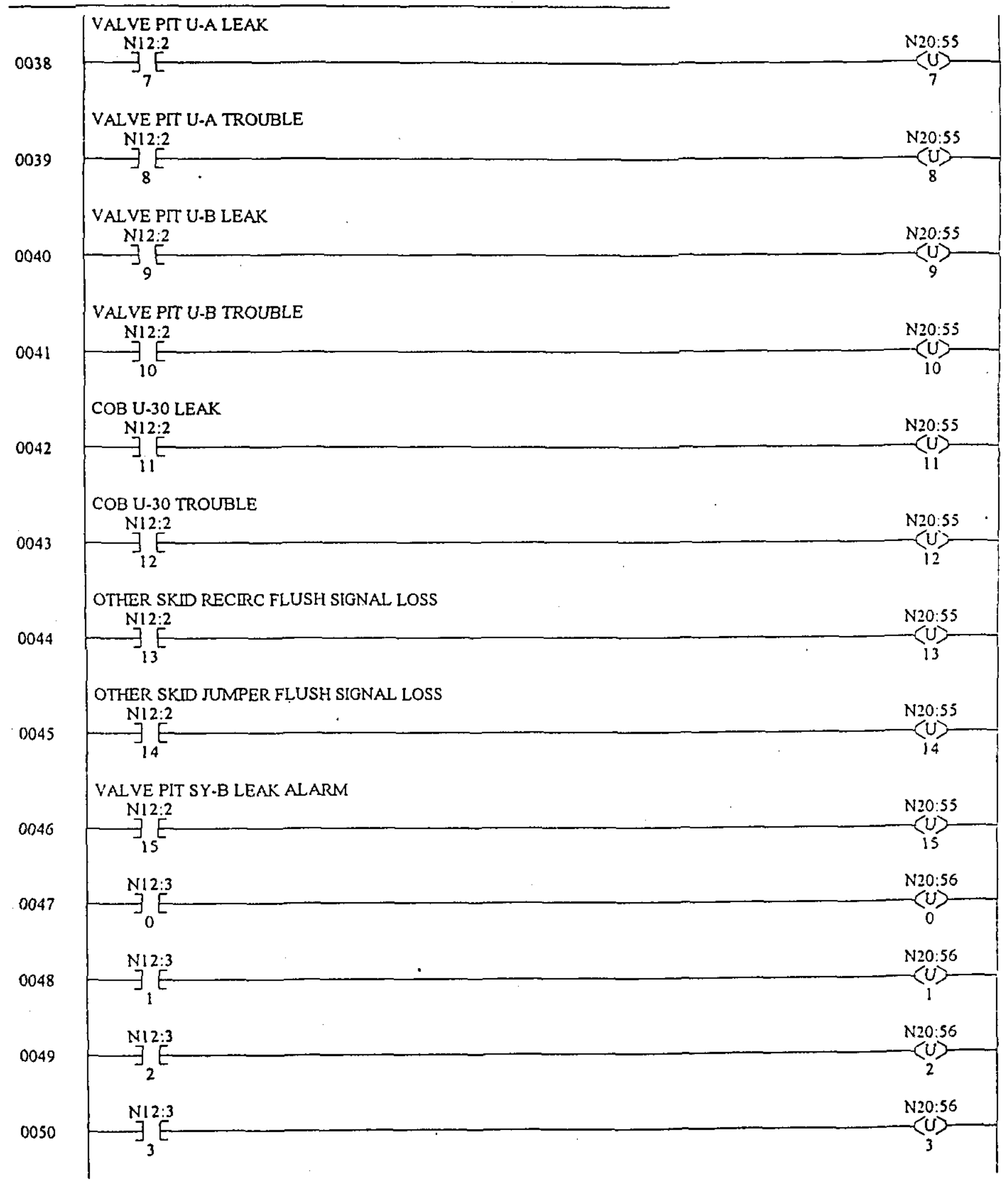


U103last.rss

LAD 17 - .. Total Rungs in File $=65$

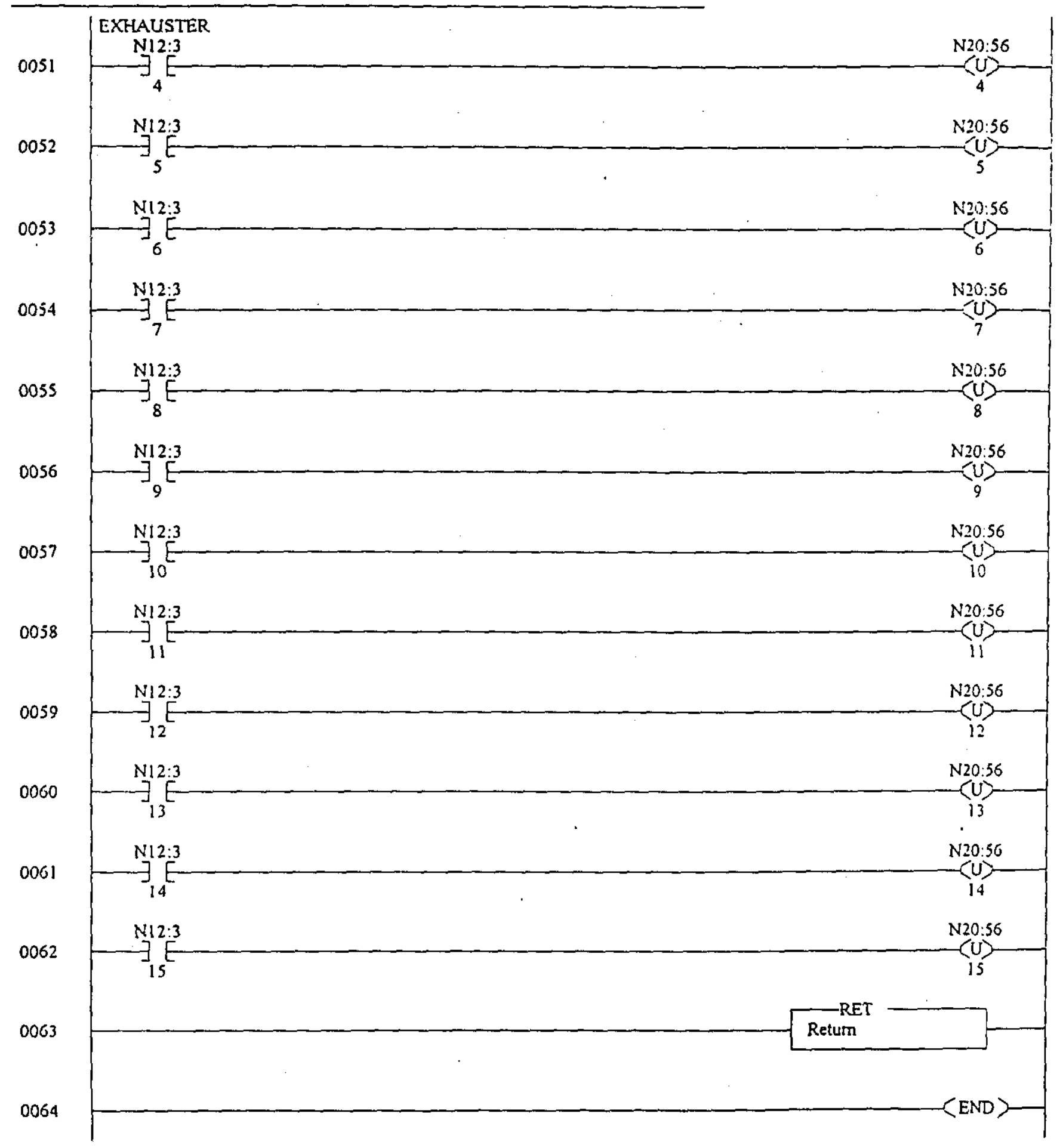


LAD 18 - - Total Rungs in File $=70$

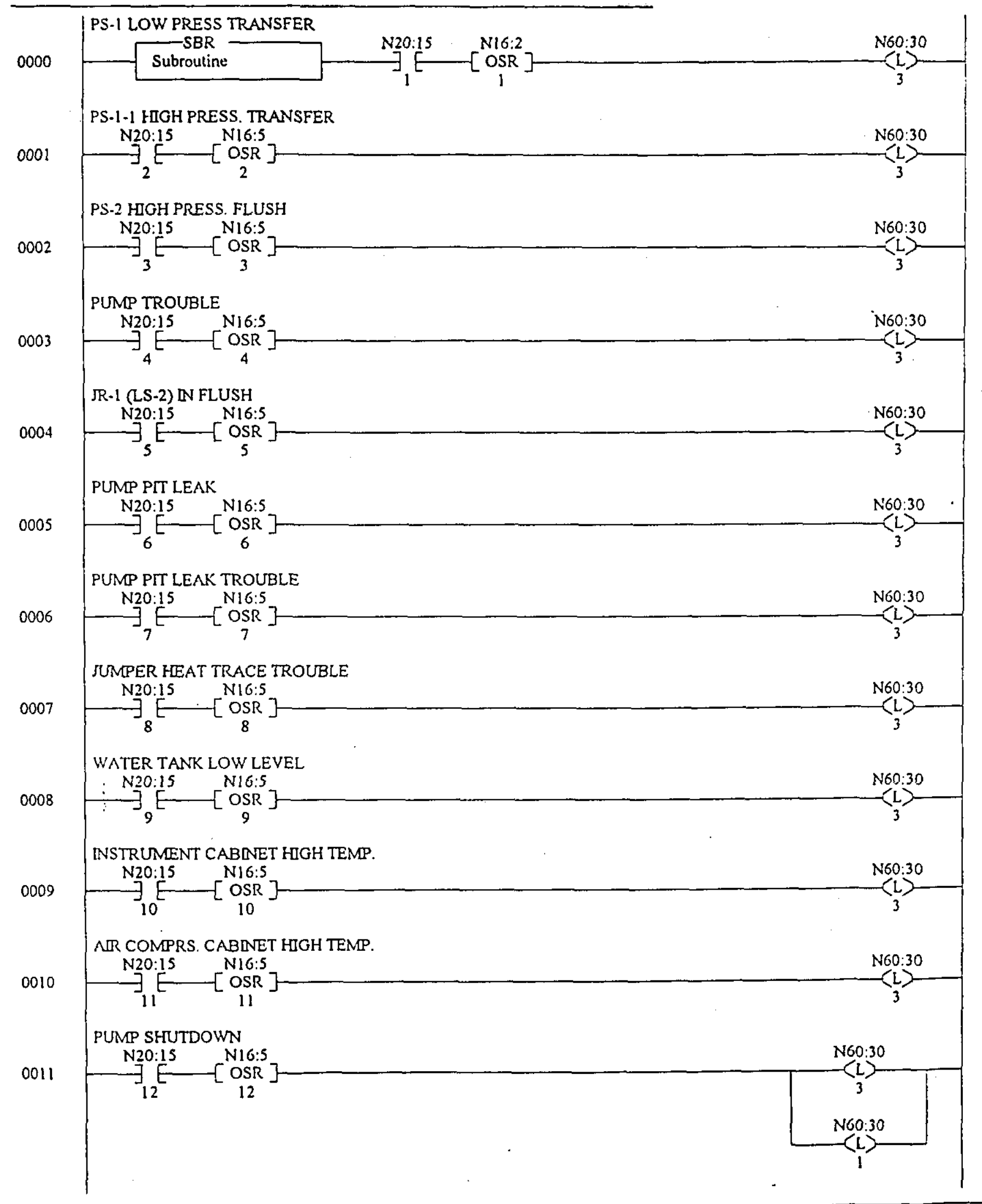

Puge 1 - 1

Monday, September 27, $1999^{\circ} .08: 16: 21$ 


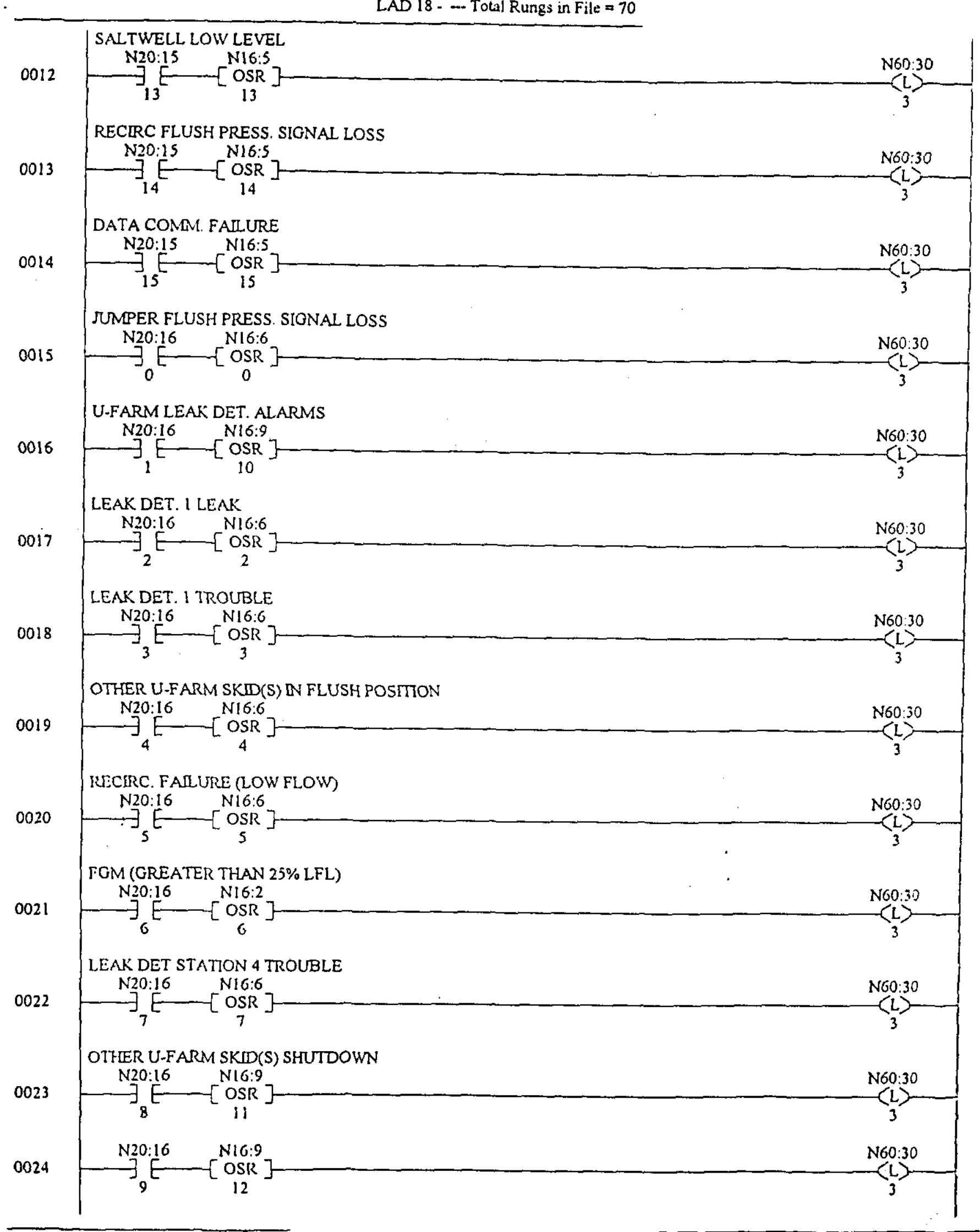

Page 1 - 2 
U103last.rss

LAD $18 \cdot-$ Total Rungs in File $=70$

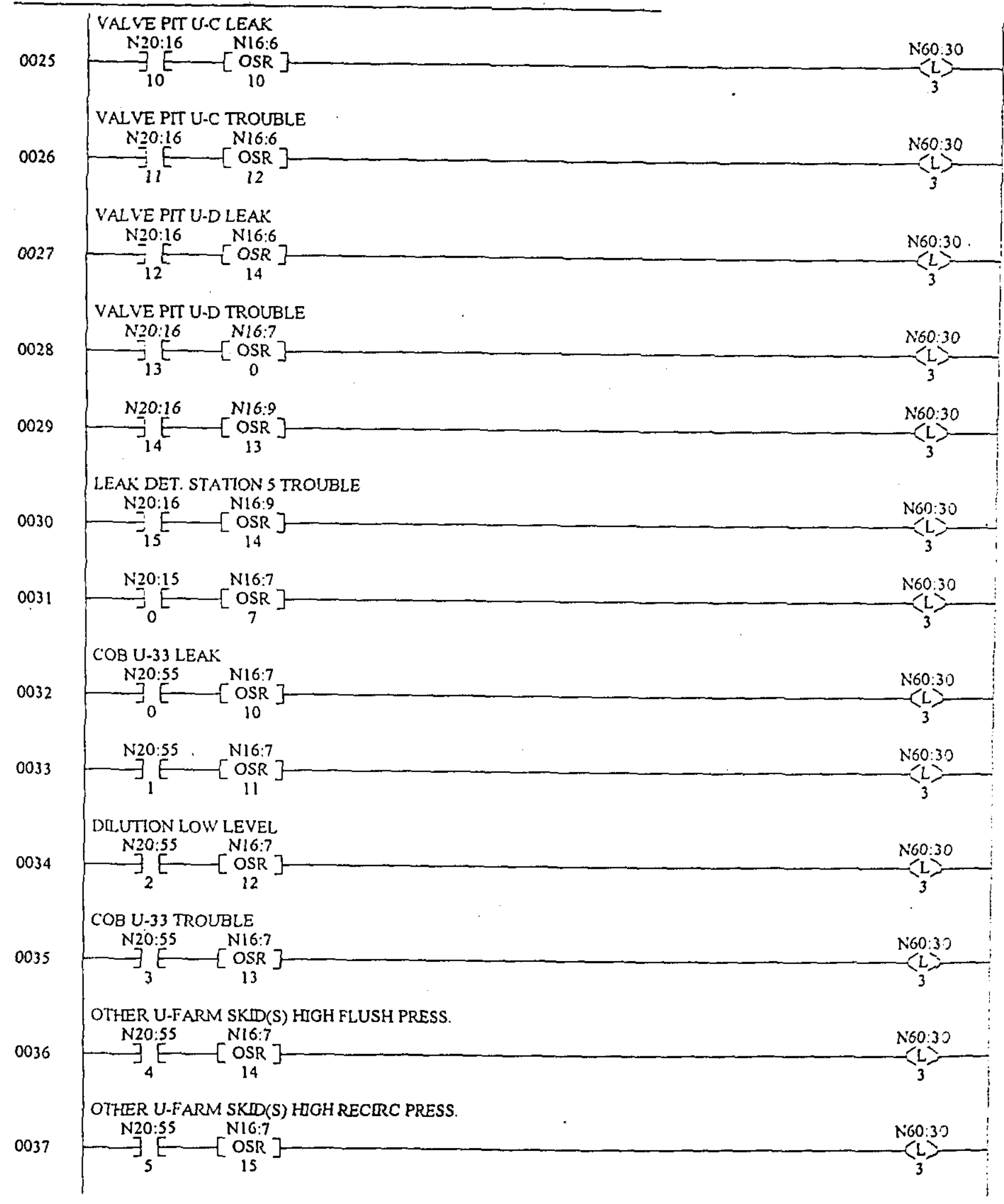


LAD 18 - - Total Rungs in File $=70$

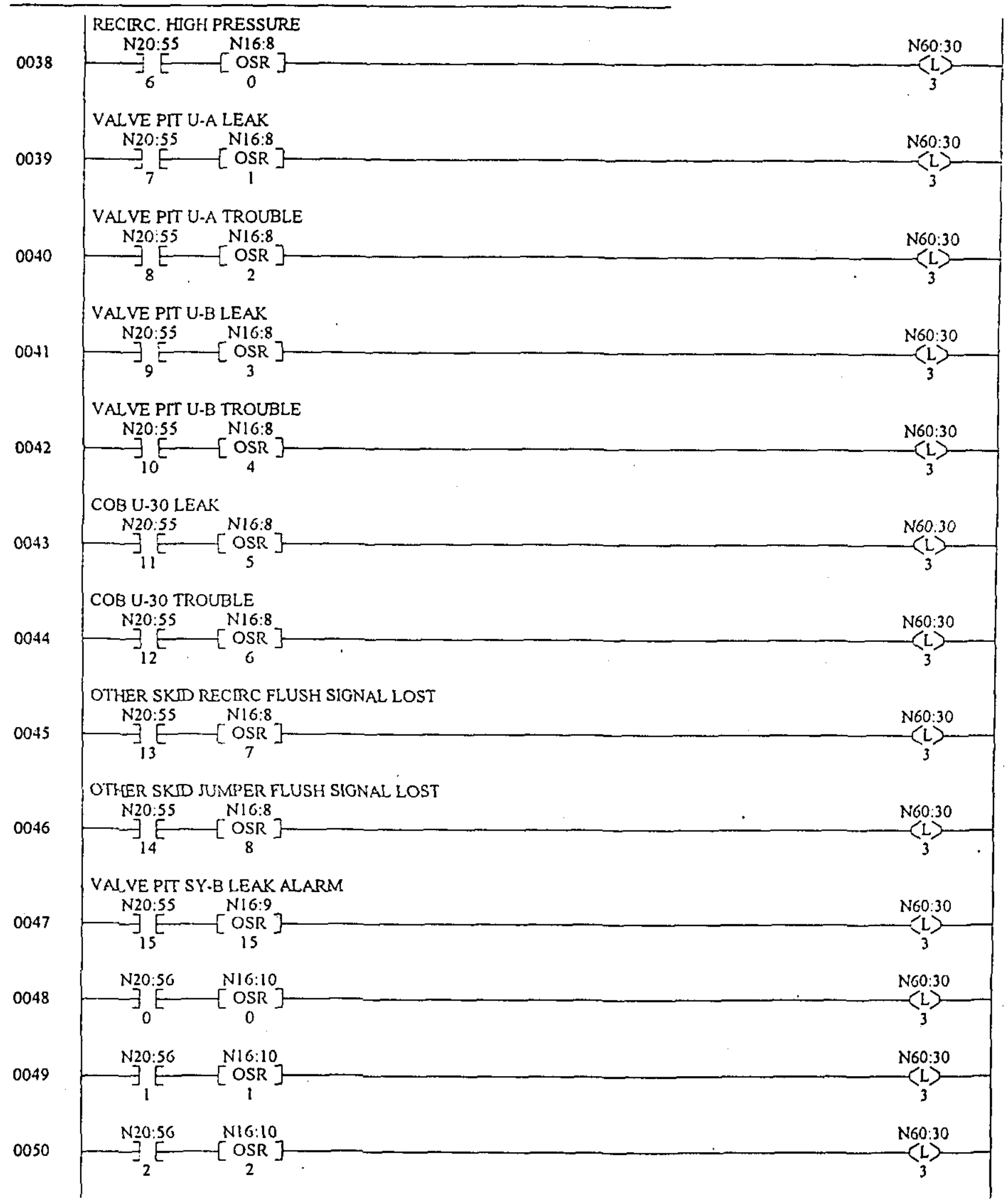




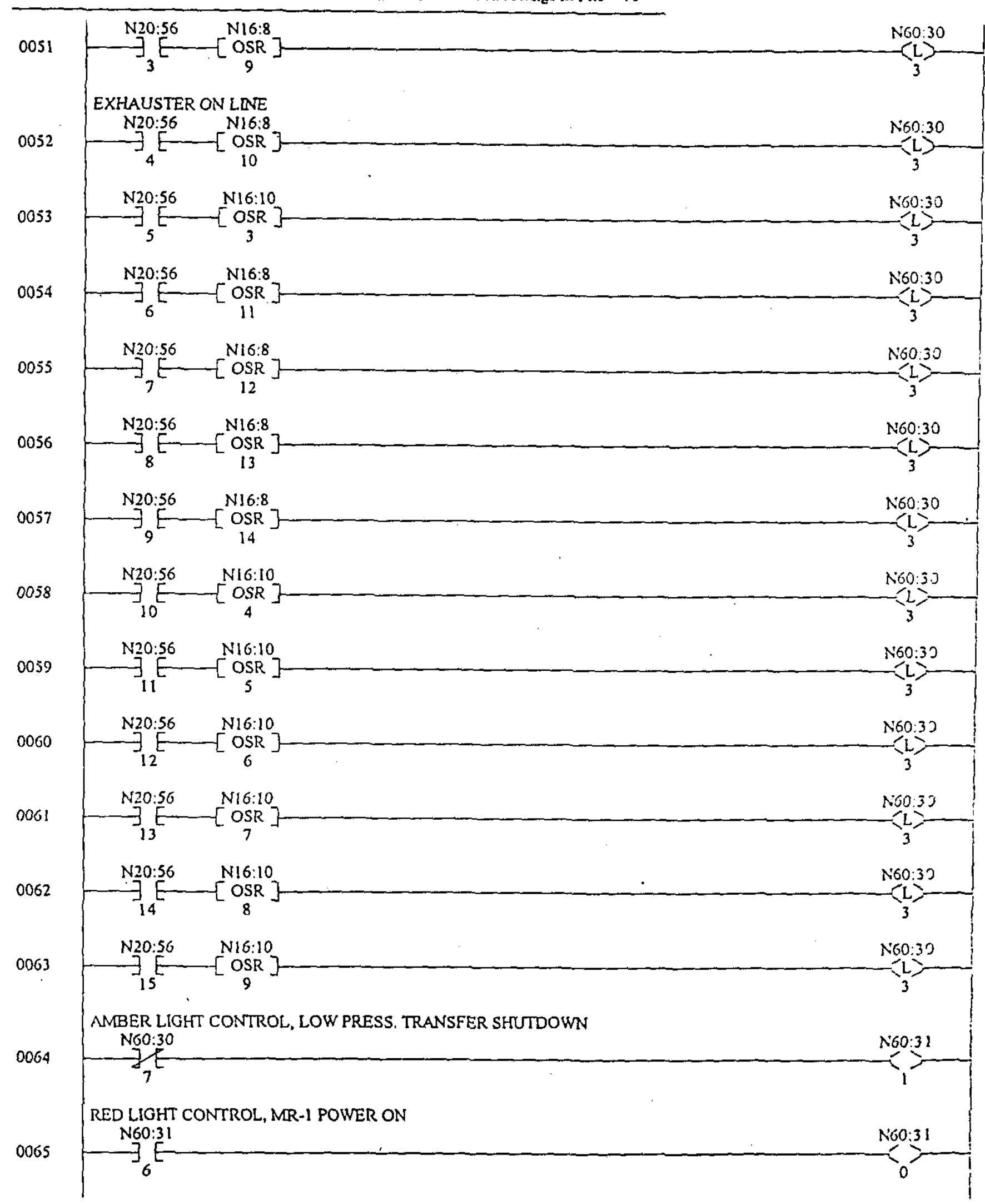


U103last.rss

LAD 18 - - Total Rungs in File $=70$

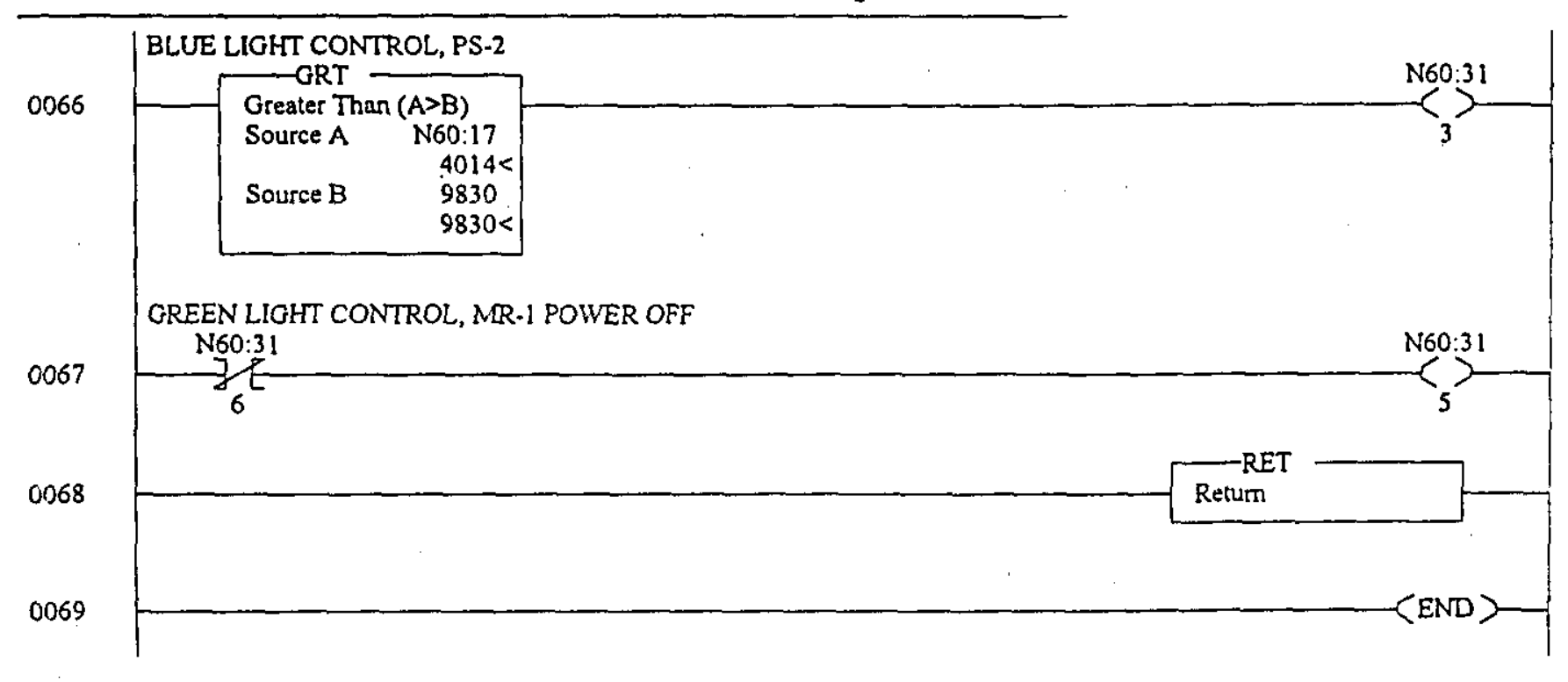

Page I- 6

Monday, Septembur 27, 1999-08:16:25 
U103last.rss

LAD $19--$ Total Rungs in File $=9$

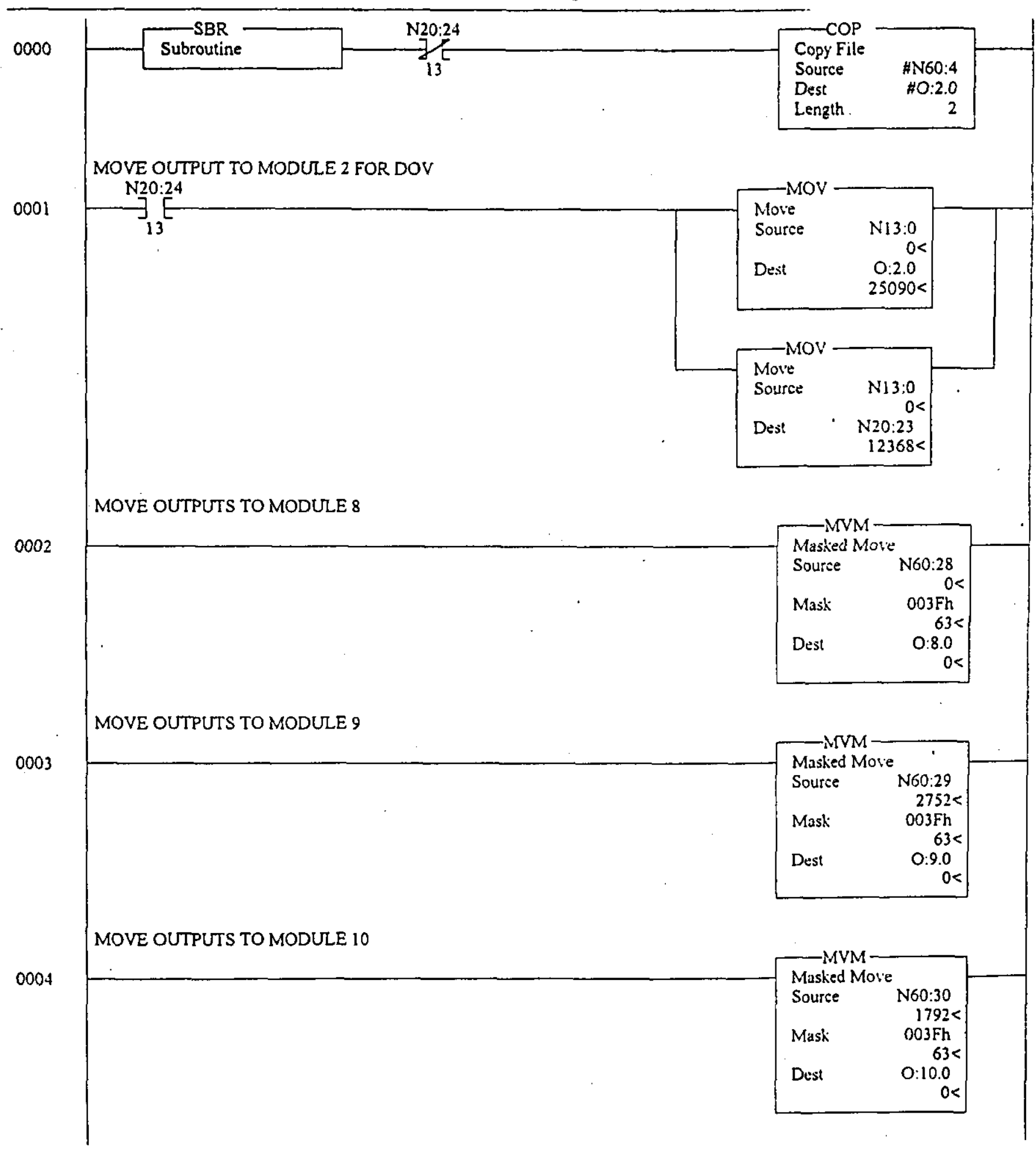


LAD 19 - -- Total Rungs in File $=9$

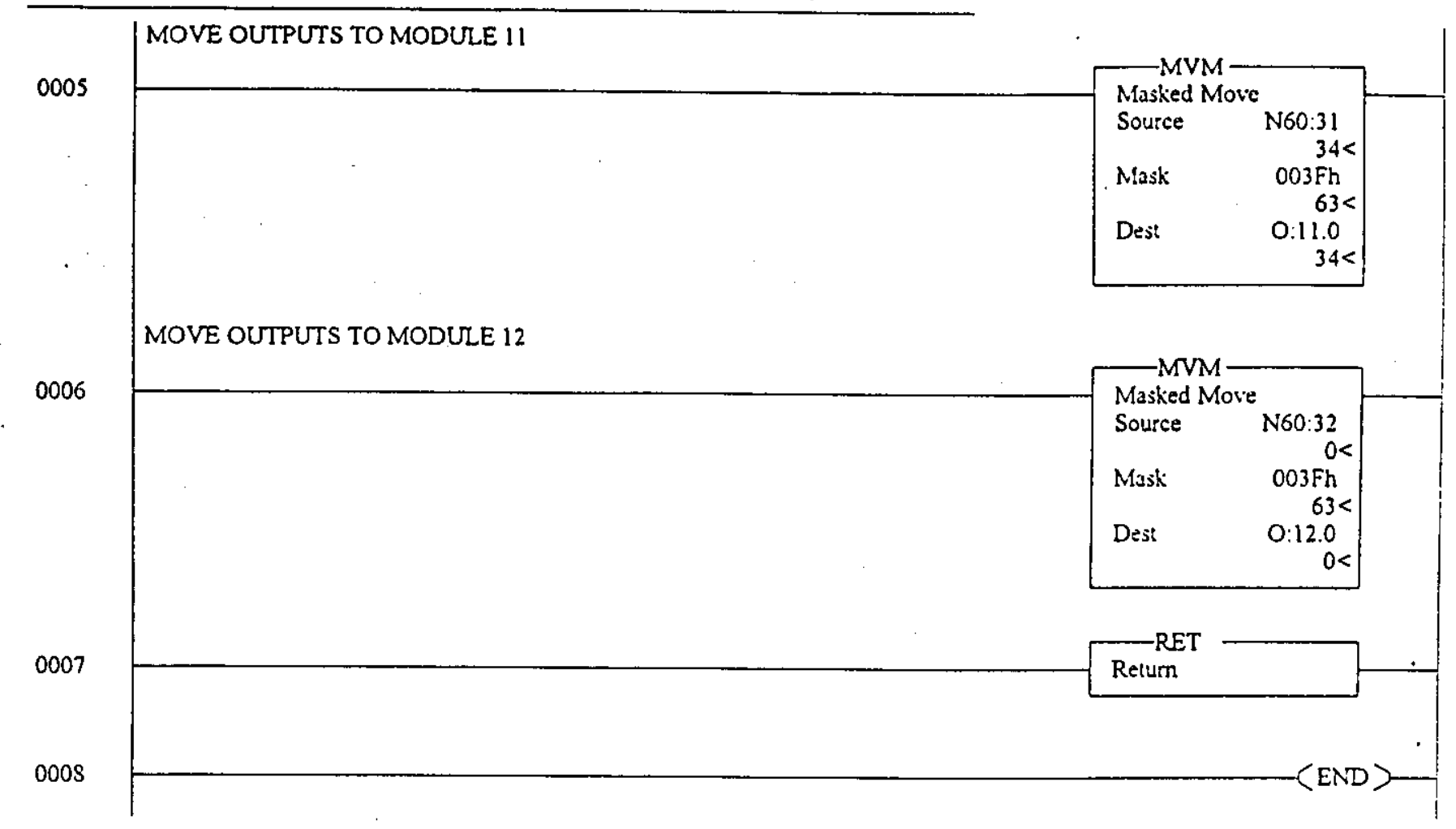

Puge 1 - 2

Monduy, September 27, 1999 - 08:16:25 


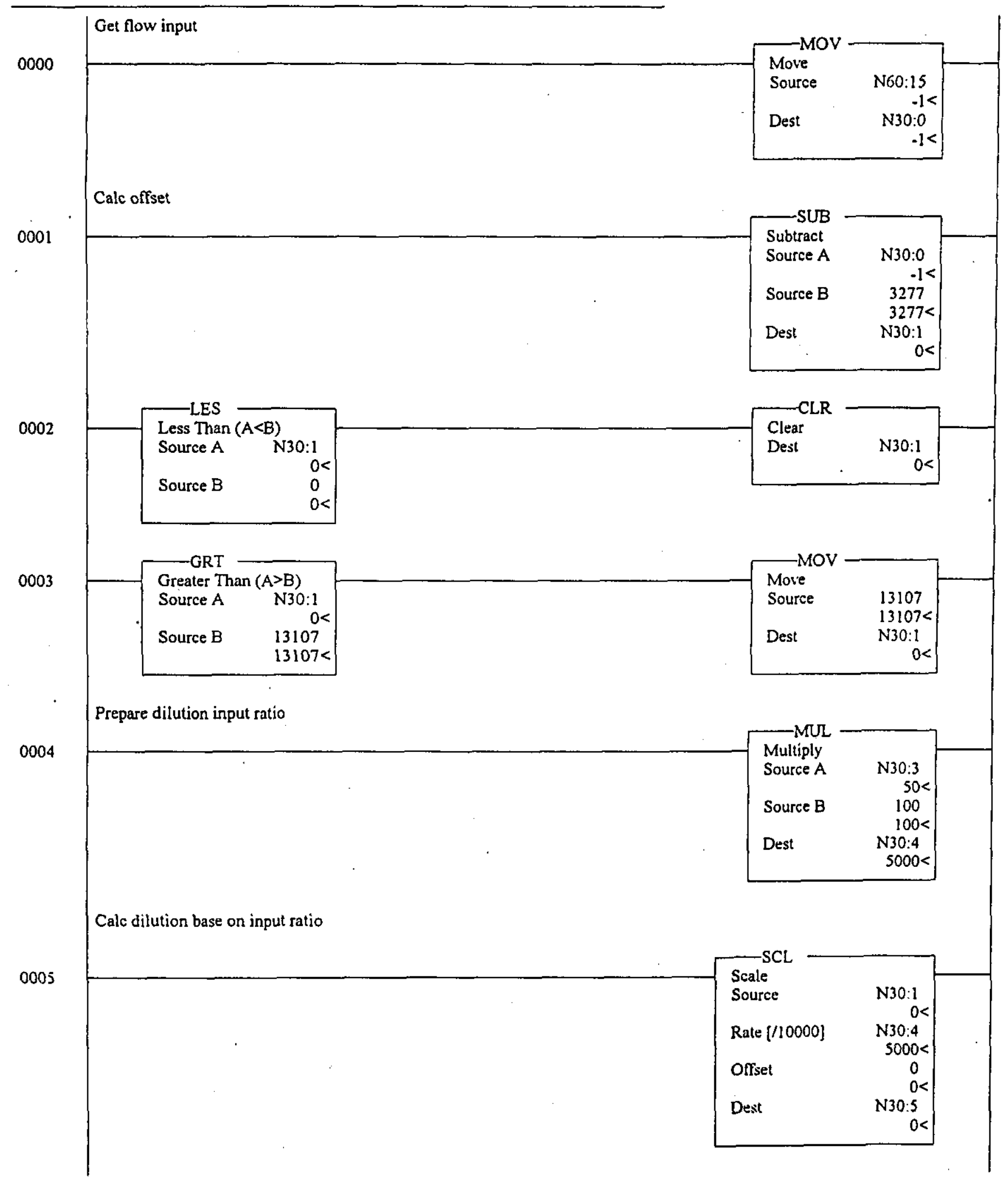


U103last.rss

LAD 20 - Total Rungs in File $=10$

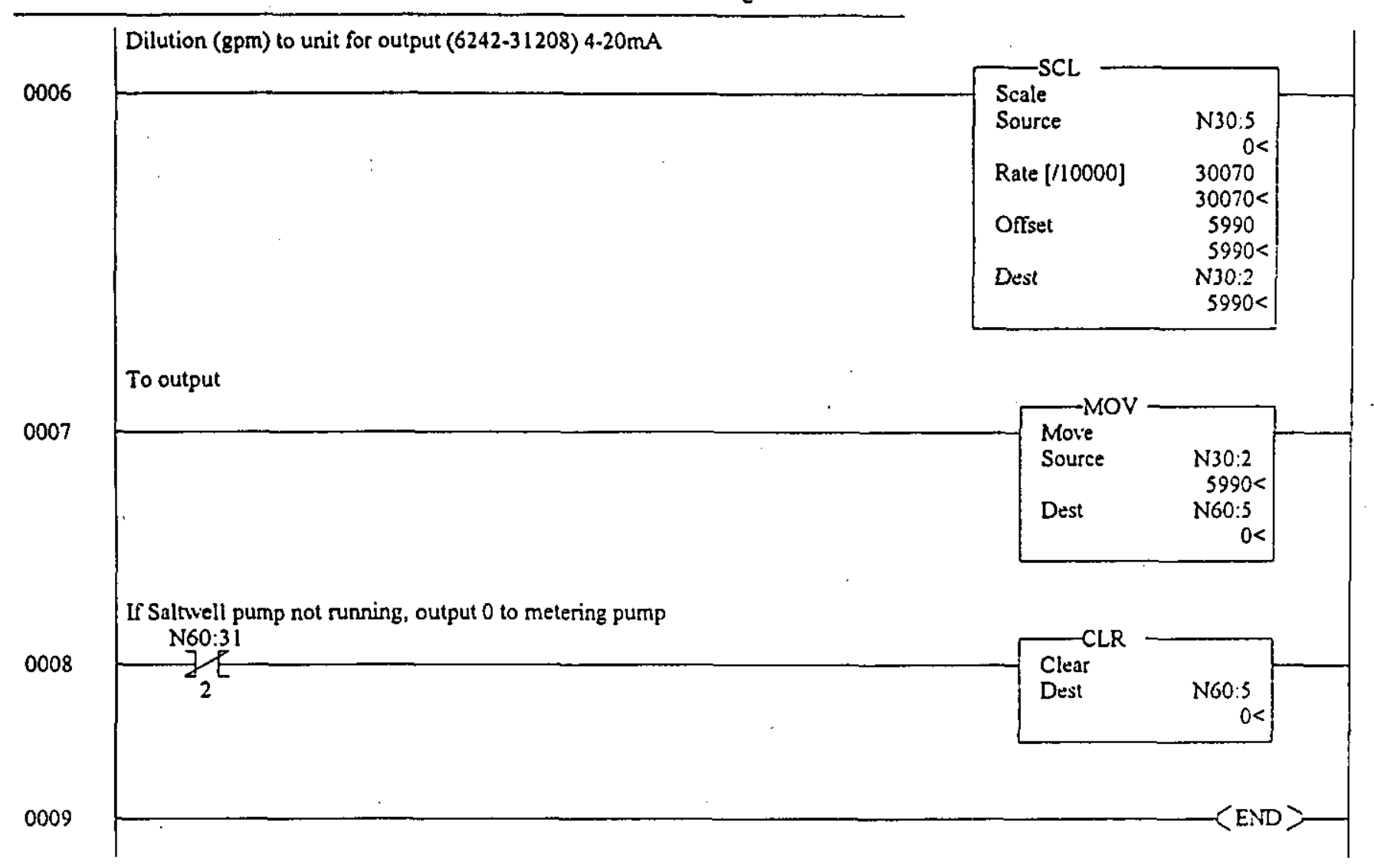

